Gifts of the Immigrants, Woes of the Natives: Lessons from the Age of Mass Migration

Marco Tabellini

Working Paper 19-005 


\title{
Gifts of the Immigrants, Woes of the Natives: Lessons from the Age of Mass Migration
}

\author{
Marco Tabellini
}

Harvard Business School

Working Paper 19-005 


\title{
Gifts of the Immigrants, Woes of the Natives: Lessons from the Age of Mass Migration*
}

\author{
Marco Tabellini ${ }^{\dagger}$ \\ Harvard Business School
}

April 2, 2019

\begin{abstract}
In this paper, I jointly investigate the political and the economic effects of immigration, and study the causes of anti-immigrant sentiments. I exploit exogenous variation in European immigration to US cities between 1910 and 1930 induced by World War I and the Immigration Acts of the 1920s, and instrument immigrants' location decision relying on pre-existing settlement patterns. I find that immigration triggered hostile political reactions, such as the election of more conservative legislators, higher support for anti-immigration legislation, and lower redistribution. Exploring the causes of natives' backlash, I document that immigration increased natives' employment, spurred industrial production, and did not generate losses even among natives working in highly exposed sectors. These findings suggest that opposition to immigration was unlikely to have economic roots. Instead, I provide evidence that natives' political discontent was increasing in the cultural differences between immigrants and natives. Results in this paper indicate that, even when diversity is economically beneficial, it may nonetheless be socially hard to manage.
\end{abstract}

Keywords: Immigration; Political Backlash; Age of Mass Migration; Cultural Diversity JEL Codes: J15, J24, N32

${ }^{*}$ I am grateful for the comments and suggestions received from the editor Nicola Gennaioli, as well as four anonymous referees. I am also extremely grateful to Daron Acemoglu, Alberto Alesina, David Autor, and Heidi Williams for their invaluable advice and guidance throughout this project. I thank Maristella Botticini, Leah Boustan, Francesco Giavazzi, and Frank Schilbach, and participants at MIT Political Economy and Harvard Economic History lunches, Barcelona GSE conferences, Brown, Chicago Booth, Cornell, EIEF, Harvard Kennedy School, HBS, IIES, LBS, MIT, NBER Summer Institute, NYU Stern, Stanford, UCLA (Luskin), University of Toronto for useful comments. Ludovica Ciasullo, Viola Corradini, and Beatrice Bonini provided excellent research assistance. I am thankful to the George and Obie Shultz Fund and to IGIER for their generous funding. All remaining errors are mine.

${ }^{\dagger}$ mtabellini@hbs.edu 


\section{Introduction}

The recent immigration waves to Europe and the US have generated a heated political debate, and proposals to introduce or tighten immigration restrictions are becoming increasingly common. A growing literature has shown that the inflow of immigrants has increased support for populist, far right parties in several Western democracies (Becker and Fetzer, 2016; Dustmann et al., 2019; Halla et al., 2017). However, despite the rising importance of immigration in the political arena, both the causes and the consequences of anti-immigration sentiments are not fully understood.

First, despite the evidence on voting, the link between support for anti-immigration parties and the actual policies implemented in response to immigration has not been systematically investigated. This may be partly due to the fact that, with some recent exceptions, anti-immigrant votes often accrue to marginal parties that are unable to influence the design and the implementation of government policies. Since we ultimately care about the actions and the reforms undertaken by political actors, it is crucial to understand which policies, if any, are affected by immigration, and why. Will legislation regulating the immigration regime be introduced? Will redistribution and taxation be changed to prevent immigrants from having access to public goods?

Second, evidence on the causes of anti-immigration sentiments is mixed, and two main hypotheses have been proposed. The first one is economic in nature, and argues that political discontent emerges from the negative effect of immigration on natives' employment and wages. ${ }^{1}$ While this idea is consistent with findings in Borjas (2003), Dustmann et al. (2017), and Monras (2018) among others, it is in contrast with results in Card (2001, 2005), Foged and Peri (2016), and Ottaviano and Peri (2012) who document that immigrants have a negligible, or even positive, impact on natives' earnings. ${ }^{2}$ The second hypothesis is that natives' backlash has cultural roots. Both today and in the past, a recurring theme in the rhetoric of anti-immigration politicians is that immigrants' cultural diversity is an obstacle to social cohesion and a menace to the values of hosting communities (Abramitzky and Boustan, 2017). Historical and anecdotal accounts present many examples of cultural opposition to immigration (Higham, 1955; Spiro, 2009). Yet, even though local amenities (e.g. crime or school quality) have been shown to be important determinants of natives' reactions to immigration (Card et al., 2012, Halla et al., 2017, and Sniderman et al., 2004), there is scant evidence on the extent to which culture directly triggers political backlash and policy change.

\footnotetext{
${ }^{1}$ Another, somewhat related economic explanation for natives' opposition to immigration is that immigrants are (often incorrectly) perceived as a fiscal burden (Alesina et al., 2018).

${ }^{2}$ Clemens et al. (2018), Lafortune et al. (2019), and Lewis (2011) find that the labor market effects of immigration can be largely mediated by firms' investment and technology adoption. See Lewis and Peri (2015) for a detailed review of this literature.
} 
This paper studies in a unified framework the political and economic effects of immigration across US cities between 1910 and 1930, a period when the massive inflow of European immigrants was abruptly interrupted by two major shocks, World War I and the Immigration Acts (1921 and 1924). Between 1850 ad 1915, during the Age of Mass Migration, more than 30 million people moved from Europe to the United States (Abramitzky and Boustan, 2017), and the share of immigrants in the US population was even higher than it is today (Figure 1). ${ }^{3}$ Also at that time, anti-immigration sentiments were widespread, and the introduction of immigration restrictions was advocated on both economic and cultural grounds.

This setting offers three main advantages. First, by jointly analyzing economic and political outcomes, I can test the relationship between economic insecurity and natives' political reactions. Given the disagreement in the literature on the economic effects of immigration (Dustmann et al., 2016), this is crucial to shed light on the causes of natives' backlash. Second, since cities were independent fiscal units and because the US went through a major change in its (immigration) policy regime, I can not only study the impact of immigration on voting, but I can also measure its effects on actual policies - both at the local and at the national level. Finally, in contrast with more recent immigration episodes where migrants often come from culturally homogeneous groups, at the beginning of the twentieth century there existed wide variation in immigrants' cultural background (e.g. in terms of language or religion). Exploiting such variation, I can assess how the political effects of immigration varied with cultural distance between immigrants and natives.

The key feature of this empirical setting is that the national shocks to immigration triggered by WWI and the Immigration Acts affected migration flows from different sending regions to different degrees. Since immigrants tend to cluster along ethnic lines (Card, 2001), the differential effect of these shocks across European countries generated significant variation in the number as well as in the mix of immigrants received by US cities over time. I exploit such variation to overcome the concern that immigrants' location decision might be itself influenced by political and economic conditions. In addition to controlling for city time invariant and state time varying unobserved characteristics, I construct a "leave-out" version of the shift-share instrument commonly adopted in the literature (Card, 2001).

The shift-share instrument rests on the empirical regularity that immigrants cluster geographically in receiving countries, and newcomers tend to settle where their ethnic community is larger, due to family ties and social networks (Stuart and Taylor, 2016). Starting from this observation, I predict the number of immigrants received by US cities over time by interacting 1900 settlements with subsequent migration flows from each sending region,

\footnotetext{
${ }^{3}$ The total number of foreign-born residents is, however, higher today. Also, contemporary immigration is underestimated because of the presence of large numbers of undocumented immigrants (see the dashed line in Figure 1 and Borjas, 2016).
} 
net of the individuals that eventually settled in a given city's metropolitan statistical area $(\mathrm{MSA}){ }^{4}$

The validity of this instrument hinges on one critical assumption: the city-specific characteristics that attracted early movers from any given country must not affect the evolution of local economic and political conditions in subsequent decades (see also Borusyak et al., 2018, and Goldsmith-Pinkham et al., 2018). To assess the validity of this assumption, I perform several checks. First, I show that pre-period changes in the outcomes of interest are uncorrelated with subsequent immigration predicted by the instrument. Second, I separately control for a time-varying (predicted) measure of industrialization and interact year dummies with several pre-migration city characteristics. I devote special attention to the concern that the 1900 fraction of immigrants, which mechanically predicts higher immigration in subsequent decades, might have had independent, time-varying effects on either economic or political outcomes. To do so, I allow my estimates to vary flexibly depending on city 1900 immigrant population as well as on the size of the ethnic enclave from each sending country.

Next, I deal with the possibility that aggregate migration flows from each sending country may be endogenous to local economic conditions in US cities. In online appendix B1, I replace the actual number of immigrants (from each origin) entering the United States with that predicted exploiting variation solely induced by World War I and the Immigration Acts. ${ }^{5}$ Finally, I exploit the fact that WWI and the Immigration Acts unexpectedly altered both the number and the composition of immigrants, and document that these shocks lowered the serial correlation in migration flows to US cities. I provide evidence that, in this specific context, the shift-share instrument is unlikely to conflate the short and the long run responses of the economy to immigration (Jaeger et al., 2018).

I begin my analysis by studying the political effects of immigration. First, I find that cities cut public goods provision and taxes in response to immigration. In the context of a sticky political process, immigration might have reduced public spending and tax revenues per capita by mechanically increasing city population. However, I show that not only per capita, but also total public spending and tax revenues were lower in cities receiving more immigrants. Moreover, the reduction in tax revenues was entirely driven by declining tax rates, while the fall in public goods provision was concentrated in categories where either inter-ethnic interactions are likely to be more salient (e.g. education) or poorer immigrants would get larger implicit transfers (e.g. sewerage, garbage collection). These findings suggest that immigrants were perceived as a fiscal burden, and that immigration reduced natives' demand for redistribution. Consistent with this interpretation, in 1907, Prescott Hall, one

\footnotetext{
${ }^{4}$ In my baseline specification, I consider only immigration from Europe (online appendix Table A1), but results are robust to extending the analysis to all other non-European countries (online appendix D5).

${ }^{5}$ In online appendix B2, similarly to Sequeira et al. (2019), I also construct a measure of predicted immigration determined uniquely by weather shocks in origin countries.
} 
of the leaders of an influential anti-immigration movement, the Immigration Restriction League, stated that US cities were "receiving a great many immigrants who are not only worth nothing to the country, but are a positive [public] expense".

Second, immigration reduced the pro-immigrant party's (i.e., Democrats) vote share, and was associated with the election of more conservative representatives. While the ideological distance on immigration between Republicans and Democrats was less pronounced than it is today, most naturalized immigrants supported the Democratic Party. The Irish are the most emblematic example (Erie, 1990), but this was true also for other ethnic or religious groups such as the Italians and the Catholics (Kleppner, 1979; Luconi, 1996). Finally, and most directly reflecting natives' demand for anti-immigration policies, members of the House representing cities more exposed to immigration were significantly more likely to support the National Origins Act of 1924, which put an end to the era of unrestricted immigration to the US.

After establishing that immigration triggered widespread, hostile political reactions, I investigate the potential causes for natives' backlash. I start from the first, and perhaps most obvious possibility: immigrants might have increased labor market competition, lowering wages and raising unemployment among native workers. Yet, in contrast with this idea, I find that immigration had a positive and statically significant effect on natives' employment. My estimates are quantitatively large, and imply that a 5 percentage points increase in immigration (roughly one standard deviation) increased natives' employment by 1.4 percentage points, or by $1.6 \%$ relative to its 1910 level.

Since no comprehensive data on wages is available for this period, as commonly done in the literature (e.g. Abramitzky et al., 2012, 2014), I proxy for natives' income using $(\log )$ occupational scores, and document that immigration promoted natives' occupational upgrading. ${ }^{6}$ These results were made possible by two mechanisms. First, immigration increased firms' investment and productivity, generating an outward shift in labor demand. Second, because of complementarity, natives moved away from occupations that were more exposed to immigrants' competition and specialized in jobs where they had a comparative advantage and, because of discrimination, immigrants did not have access to.

Even though immigration had, on average, positive effects on natives' employment and occupational standing, it is possible that economic losses were concentrated on some specific groups, who were able to mobilize and demand political protection. Although I cannot entirely rule out this interpretation, I provide evidence against it. First, I document that even in occupations that were highly exposed to immigrants' competition, natives were not more likely to be unemployed. Second, using data digitized from the Census of Manufactures,

\footnotetext{
${ }^{6}$ As discussed below, occupational scores assign to an individual the median income of his job category in 1950, and can thus be used as a proxy for lifetime earnings (Abramitzky et al., 2014).
} 
I show that in the sector most exposed to immigration (i.e. manufacturing), there was no significant reduction in wages. These data do not distinguish between immigrant and native workers, and new immigrants tend to be closer substitutes for previously arrived migrants than for natives. ${ }^{7}$ Hence, these findings can be interpreted as a lower bound for the negative effect (if any) - or, equivalently, as an upper bound for the absolute value of the effect - of immigration on natives' earnings.

The last part of the paper seeks to understand why, if immigration was on average beneficial and had no tangible economic costs, it nonetheless triggered political backlash. I show that natives' political reactions were increasing in the cultural distance between immigrants and natives, suggesting that backlash may have had, at least in part, non-economic foundations. I proxy for cultural diversity using both religion and linguistic distance. The use of religion, in particular, is motivated by the historical evidence that, at that time, nativism often resulted in anti-Semitism and anti-Catholicism (e.g. Higham, 1955; D'Amico and Tabellini, 2018).

While immigrants from Protestant and non-Protestant countries had very similar effects on natives' employment and on economic activity, they triggered very different political reactions. Only Catholic and Jewish, but not Protestant, immigrants induced cities to limit redistribution, favored the election of more conservative legislators, and increased support for the 1924 National Origins Act. These patterns also suggest that political backlash was unlikely to arise from increased inequality, or that cities reduced redistribution only because the median voter became richer (e.g. Meltzer and Richard, 1981). If this were to be the case, Protestant and non-Protestant immigration should have lead to similar political responses.

My findings are consistent with a long-standing idea in the literature that diversity can be economically beneficial because of gains from specialization and complementarity (Alesina and La Ferrara, 2005), but may be politically hard to manage, resulting in lower preferences for redistribution (Dahlberg et al., 2012), more limited public spending (Alesina et al., 1999), and higher conflict (Bazzi and Gudgeon, 2016). My paper is also related to the recent and growing literature on the Age of Mass Migration. ${ }^{8}$ Abramitzky et al. (2012, 2014, 2018) study the selection and the assimilation of European immigrants during the Age of Mass Migration, while Ager and Hansen (2017), Lafortune et al. (2019), and Sequeira et al. (2019) investigate their impact on contemporaneous and long-run economic development.

I complement this literature in two ways. First, by contrasting the economic and the political impact of immigration, and by exploiting variation in immigrants' background, I assess how cultural and economic factors contribute to trigger natives' backlash. Second, I

\footnotetext{
${ }^{7}$ This finding has been documented in a number of works in the literature (e.g. Boustan, 2009; Goldin, 1994). I also provide direct evidence for it in online appendix E3.

${ }^{8}$ Goldin (1994) is an early and seminal contribution on the poliltical economy determinants of the introduction of the Immigration Acts.
} 
study the effects of immigration on key policy variables, such as tax rates and public spending - outcomes for which, as noted in Card (2009) and Borjas (2016) among others, despite the large debate on the consequences of immigration, little is known. ${ }^{9}$

The remainder of the paper is organized as follows. Section 2 describes the historical background. Section 3 presents the data. Section 4 lays out the empirical strategy, constructs the instrument for immigration, and presents first stage results. Section 5 studies the political effects of immigration. Section 6 investigates the effects of immigration on natives' employment and on economic activity, and provides evidence against the idea that natives' backlash was economically motivated. Section 7 documents the link between political discontent and cultural differences between immigrants natives. Section 8 summarizes the main robustness checks, which are then described in detail in the online appendix. Section 9 concludes.

\section{Historical Background}

\subsection{The Age of Mass Migration}

Between 1850 and 1915, more than 30 million people moved from Europe to the US. Until 1890, most immigrants came from the British Isles, Germany, and Scandinavia, but, from the late 1880s, immigration from Southern and Eastern Europe increased steadily, as the costs of migration fell with the advent of steam technology (Keeling, 1999). In 1870, almost $90 \%$ of the foreign born came from Northern and Western Europe, whereas less than $5 \%$ of immigrants had arrived from Southern and Eastern Europe (Figure 2). By 1920, however, the situation had changed dramatically, with the share of migrant stock from new source countries being as high as 40\%. Europeans from new regions were culturally farther from natives and significantly less skilled than those from old sending regions (Hatton and Williamson, 1998, 2006). For instance, while literacy rates of immigrants that entered the US between 1900 and 1910 were very close to one for all old sending countries, they were significantly lower for new source regions (online appendix Figures A1 and A2).

The shift in the composition of immigrants and concerns over their assimilation induced Congress to establish a commission that, between 1907 and 1911, studied the economic and social conditions of immigrants (Higham, 1955). In 1911, the Immigration Commission recommended the introduction of immigration restrictions, and in 1917, after decades of heated political debate, Congress passed a literacy test requiring that all immigrants entering

\footnotetext{
${ }^{9}$ An exception is the paper by Chevalier et al. (2018) on the effects of internal migration in post-WWII Germany on local taxation. Also, in a companion paper (Tabellini, 2018), I study how the migration of southern born African Americans affected public goods provision and government finances in northern cities during the first wave of the Great Migration.
} 
the United States had to be able to read and write (Goldin, 1994).

Even before the adoption of the literacy test, in 1914, the Age of Mass Migration came to an abrupt end due to the onset of World War I, which drastically reduced European immigration between 1915 and 1919 (Figure 3). In 1920, despite the literacy test, migration flows increased again to their 1910 levels, fueling nativist movements and generating even stronger political pressure to adopt more effective measures to curb immigration. Figure A3 plots trends of migration flows (right axis) and of the number of articles in local newspapers referring to immigration (left axis) over time, and shows that both fell dramatically during WWI, but then increased again once the war was over. In response to the growing demand for immigration restrictions, in 1921 and 1924 Congress finally passed the Immigration Acts to limit the number of immigrants that could enter the United States in a given year by introducing country-specific quotas based on 1890 immigrants' population. ${ }^{10}$

Both World War I and the Immigration Acts affected different sending countries in different ways. In particular, quotas were set so as to limit the inflow of immigrants from new sending regions, while favoring that from old sources such as the UK, Germany, and Scandinavia. Figure A4 shows the changing composition of immigrants entering the United States during the previous decade between 1900 and 1930. Until 1920, the majority of recent immigrants came from Eastern and Southern Europe, but this trend was abruptly reversed in the 1920-1930 decade, when the share of Anglo-Saxon and Scandinavian immigrants increased as a result of the Immigration Acts. Since immigrants tend to cluster along ethnic lines (Card, 2001), the post-1915 events generated substantial variation in the number as well as in the mix of immigrants received by US cities over time (Figures A5 and A6). This is the variation I exploit in my empirical analysis.

\subsection{Immigrants and the US Economy}

Historical accounts tend to view immigrants as one of the key determinants of American industrialization and economic development during the Age of Mass Migration. When describing the economic impact of European immigrants, historian Maldwyn Jones wrote that "The realization of America's vast economic potential has...been due in significant measure to the efforts of immigrants. They supplied much of the labor and technical skill needed to tap the underdeveloped resources of a virgin continent" (Jones, 1992, pp. 309-310). Similarly, John F. Kennedy argued that "every aspect of the American economy has profited from the contribution of immigrants" (Kennedy, 1964, p. 88).

\footnotetext{
${ }^{10}$ With the 1924 National Origins Act, the total number of immigrants that could be admitted in a given year was capped at 150,000. In 1921, quotas were specified reflecting the 1910 composition of immigrants. However, they were rapidly changed to 1890 to limit immigration from new sending countries even further (Goldin, 1994).
} 
During the Age of Mass Migration, the US economy had large potentials for growth. Economic historians argue that, in this context, immigrants provided a cheap and unskilled supply of labor which could not only be absorbed, but that may have even allowed industries to expand (Foerster, 1924), in turn creating new job opportunities for native workers. Even though some studies have found a negative effect of immigrants on wages (Goldin, 1994), labor shortage was a recurring theme in this historical period. For instance, in a 1906 article, the New York Times was reporting that "Need of labor is the universal cry. Demand in all parts of the country is greater than supply. Not enough immigrants. Statements from agents show that men are scarce in all the States".

Since immigrants, especially from Eastern and Southern Europe, were unskilled and had low levels of English proficiency, they may have benefitted natives because of complementarity and gains from diversity (Foged and Peri, 2016). Along these lines, in his 1971 The Transformation of the American Economy, economic historian Robert Higgs argues that "the rapid pace of industrial expansion has increased the number of skilled and supervisory positions so fast that practically all the English speaking employees have had the opportunity to rise on the scale of occupations" (Higgs, 1971, p. 420).

\subsection{Immigration and Natives' Backlash}

Despite the positive views on the contribution of immigrants to the American economy expressed by economic historians, Europeans, especially from new sending countries, faced strong political opposition. Natives' backlash culminated in the passage of the literacy test of 1917 and, more importantly, of the Immigration Acts of 1921 and 1924, which were explicitly introduced to shut down immigration from "undesirable sources". Goldin (1994) argues that concerns about unemployment and labor market competition were the main motivation for the immigration restrictions of the 1920s. Undoubtedly, the coincidence of large immigration flows with the severe macroeconomic recessions of 1907, 1913-1914, and 1919 increased the perception among native workers that immigrants were threatening American standards of living.

However, while economic considerations certainly played a role, anti-immigration sentiments tended to have deep cultural roots (Higham, 1955; Abramitzky and Boustan, 2017). This idea is very effectively summarized in a 1921 statement by Irving Fisher, who argued that "If we could leave out of account the question of race and eugenics...I should, as an economist, be inclined to the view that unrestricted immigration...is economically advantageous...the core of the problem of immigration is...one of race and eugenics" (Leonard, 2005). On a similar vein, in 1896, the first president of the American Economic Association, Francis A. Walker, claimed that the American standard of living and the quality of American 
citizenship had to be protected "from degradation through the tumultuous access of vast throngs of ignorant and brutalized peasantry from the countries of Eastern and Southern Europe" (Greenwood and Ward, 2015). ${ }^{11}$

Anti-immigration sentiments were most often directed towards two groups. First, Jews and Catholics, whose values were perceived as being different from the Puritan tradition prevailing in the US at that time. ${ }^{12}$ Second, immigrants from Eastern and Southern Europe, who were culturally and linguistically distant from natives and, because of their lower socio-economic status, were regarded as belonging to inferior races. Countless statements by politicians and newspapers articles provide examples of how Eastern and Southern European immigrants were perceived at the time. For instance, in 1916, congressman Thomas Abercrombie claimed that "The color of thousands of them [i.e. the new immigrants: Mediterraneans, Slavs, Jews] differs materially from that of the Anglo-Saxons" (Higham, 1955), while the editor of the Saturday Evening Post, Kenneth Roberts, in a 1920 article wrote that "if a few more million members of the Alpine, Mediterranean and Semitic races are poured among us, the result must inevitably be a hybrid race of people as worthless and futile as the good-for-nothing mongrels of Central America and Southeastern Europe".

\section{Data}

My analysis relies on a balanced panel of 180 US cities for the three Census years 1910, 1920, and 1930. The sample includes all cities with at least 30,000 residents in each of the three censuses, and where at least some Europeans were living in 1900 (see Figure A7 and Table A2 for the complete list of cities). I restrict attention to cities with at least 30,000 residents because below this population threshold data on public spending and government finances, two of the key outcomes of my paper, were not reported. To study the economic and political effects of immigration, I combine data from several sources.

Immigration and city population. Data on city population and on the number of immigrants by country of origin at the city and at the national level were taken from the decennial US Census of Population, made available by IPUMS (Ruggles et al., 2015). ${ }^{13}$ For

\footnotetext{
${ }^{11}$ Consistent with this qualitative evidence, D'Amico and Tabellini (2018) find that immigration induced local newspapers to adopt more racist terms when referring to immigrants, especially from Eastern and Southern Europe.

${ }^{12}$ Around the time of World War I, Jews were deemed responsible for promoting the war in order to make profits out of it. For example, in 1915 Henry Ford claimed he knew "who caused the war: German-Jewish bankers" (Watts, 2009, p. 383). During the Red Scare, and in the inter-war period more generally, Jews were often blamed for being at the origin of Bolshevism and the worldwide diffusion of Communism.

${ }^{13}$ See Table A1 for the list of European countries used in my work. In online appendix D5, I extend the sample to include all foreign born individuals. I classify individuals based on their country of origin following the classification made by IPUMS (Ruggles et al., 2015).
} 
1900, I use the $5 \%$ sample, while for 1910, 1920, and 1930, I rely on the full count census datasets.

Natives' labor market outcomes. Restricting the sample to native men in working age, I compiled data on employment, literacy, and occupation from the US Census of Population. ${ }^{14}$ Since until 1940 wage data are not available, I proxy for natives' income using (log) occupational scores, as commonly done in the literature (e.g. Abramitzky et al., 2012 and Abramitzky et al., 2014). Occupational scores assign to an individual the median income of his job category in 1950 and, as discussed in Abramitzky et al. (2014), represent a proxy for lifetime earnings.

Economic activity. I digitized city-level data from the quinquennial Census of Manufactures between 1904 and 1929 for the following variables for the manufacturing sector: value added by manufacture, value of products, establishment size, capital utilization (proxied by horsepower), total employment, and average wages. ${ }^{15}$ Wage data is a potentially valuable piece of information, since, as noted above, the US Census of Population did not collect income data prior to 1940. While manufacturing wages were not separately reported for immigrants and natives, they can nonetheless be used to complement results on employment, skill ratios, and natives' occupational scores.

Public spending and government finances. Data on public spending and city finances were digitized from the Financial Statistics of Cities for years 1906, 1910, 1919, and 1930. ${ }^{16}$ These are annual reports, available from 1906 onwards for cities with population above 30,000 (until 1934) or 100,000 (from 1934 onwards). From the Financial Statistics of Cities, I obtained data on land area, total and property tax revenues, property values, property tax rates, and public spending (total and by category).

Presidential elections. Data on electoral returns (votes shares and turnout) for Presidential elections come from Clubb et al. (1990). Since these data are available only at the county level, I aggregated them up to the MSA, fixing boundaries to 1940, and performed the analysis using MSA-level immigration, matching cities to the corresponding MSA. ${ }^{17} \mathrm{Be}-$ cause Presidential elections are held every four years, I computed the average between the

\footnotetext{
${ }^{14}$ In my analysis, I focus on the age range 15-65, but results are unchanged when selecting different age combinations (see also Carlana and Tabellini, 2018). In 1920, the US Census did not report employment status, but rather only an indicator for holding any gainful occupation. For this year, I imputed values from the latter to proxy for employment. I also report results based solely on labor force participation rather than employment.

${ }^{15}$ I use 1909, 1919, and 1929 data to proxy for 1910, 1920, and 1930 respectively. I make use of 1904 data to test if pre-period changes in outcomes are correlated with subsequent changes in predicted immigration.

${ }^{16}$ Since data for 1920 is missing, I digitized the 1919 and 1921 volumes. Results are robust to using 1921 in place of 1919, but 1919 is preferable since 1921 data was not reported for several cities. Data for 1906 is used to test the validity of the empirical strategy.

${ }^{17}$ Matching cities to MSAs lowers the number of units from 180 to 127. However, data on Presidential elections are not available for Washington DC, further reducing the number of MSAs to 126.
} 
closest two elections after each Census year. That is, for 1910 and 1930, I averaged electoral results from 1912 and 1916 and from 1932 and 1936 respectively, while for 1920, I considered 1920 and 1924. Results are unchanged when taking the average from the two closest election years, i.e. 1908 and 1912 for 1910, and 1928 and 1932 for 1930 (see online appendix D8).

Legislators' ideology. I collected data on congressmen ideology between 1910 and 1930 from Voteview, for Congresses 61, 66, and 71 respectively. ${ }^{18}$ Following Autor et al. (2017) as well as a vast political science literature, I proxy for politicians' ideology using the first dimension of the Poole-Rosenthal DW Nominate scores, which rank congressmen on an ideological scale from liberal to conservative using voting behavior on previous roll-calls (Poole and Rosenthal, 1985; McCarty et al., 2006). To exploit local geographic variation, I restrict my attention to the House of Representatives, and use digital boundary definitions of US congressional districts from Lewis et al. (2013) to match cities to their corresponding district in any given year.

When constructing this dataset, two problems must be dealt with. First, boundaries of congressional districts vary over time. Second, a single congressional district may represent multiple cities, while the same city may belong to more than one district. To address these issues, I follow Autor et al. (2017) and conduct the analysis at the city by congressional district level. The city-to-congressional district mapping is almost identical for the $66^{\text {th }}$ and the $71^{\text {st }}$ Congress, but redistricting between the $61^{\text {st }}$ and the $66^{\text {th }}$ Congress, especially in Massachusetts and Pennsylvania, prevents the construction of a balanced panel which includes all the cities in my sample. Below, I present results both for the unbalanced panel and for the balanced panel of cities whose congressional districts were unchanged. ${ }^{19}$

Representatives' voting behavior. Data on voting patterns on the National Origins Act of 1924 come from Swift et al. (2000). This dataset includes the name, the district represented, the main demographic characteristics, and the voting behavior on any rollcall of each representative in all US Congress between 1789 and 1989. As for congressmen ideology, I focus on the House of Representatives and conduct the analysis at the city by congressional district, matching each representative to the corresponding city (or cities) in my sample in the $68^{\text {th }}$ Congress (when the National Origins Act was passed). ${ }^{20}$

Table 1 reports the summary statistics for the main variables used in my analysis. City population ranges from more than 6.9 million (New York City in 1930) to as little as 30,200 (Pasadena in 1910). There is also wide variation in the fraction of immigrants across cities and over time, which was higher in the northeastern states of New Jersey, New York, Con-

\footnotetext{
${ }^{18}$ To assess the validity of the empirical strategy, I also compiled data for the $56^{\text {th }}$ Congress.

${ }^{19}$ The unbalanced and the balanced panels are composed respectively of 157 and 146 city to congressional district units.

${ }^{20}$ Whenever multiple congressmen represent the same city, I average their votes on the Immigration Act to create a unique value, which is then assigned to that city.
} 
necticut, and Massachusetts, and lower in the US South. As already discussed in Section 2, immigration fell significantly between 1910 and 1930, because of both World War I and the Immigration Acts: in 1910, the fraction of immigrants over city population was, on average, 0.18 , but this number fell to 0.12 in 1930. Even starker was the decline in the fraction of foreign born that entered the United States in the previous decade, which moved from an average of 0.08 in 1910 to 0.02 in 1930.

Immigration and most of the fiscal data are available for all the 540 city-year observations in my sample. However, employment outcomes were missing for Sacramento (CA) and New Bedford (MA) in 1920, whereas data from the Census of Manufactures were not reported for a handful of cities, leaving me with 538 and 525 observations respectively. ${ }^{21}$ Finally, aggregating cities to MSAs (for Presidential elections) and to congressional districts (for legislators' ideology) reduces the number of observations to 378 and 470 respectively.

\section{Empirical Strategy}

In this section, I introduce the baseline estimating equation (Section 4.1), construct the instrument for immigration (Section 4.2), and report first stage results (Section 4.3).

\subsection{Baseline Estimating Equation}

To study the political and economic effects of immigration, I focus on the three Census years between 1910 and 1930, and I estimate

$$
y_{c s t}=\gamma_{c}+\delta_{s t}+\beta I m m_{c s t}+u_{c s t}
$$

where $y_{c s t}$ is the outcome for city $c$ in state $s$ in Census year $t$, and $I m m_{c s t}$ is the fraction of immigrants over city population. $\gamma_{c}$ and $\delta_{s t}$ are city and state by year fixed effects, implying that $\beta$ is estimated from changes in the fraction of immigrants within the same city over time, compared to other cities in the same state in a given year. Since city population could itself be an outcome of immigration, the number of immigrants is scaled by predicted (rather than actual) city population, constructed by multiplying 1900 population by average urban growth in the US, excluding that of the Census division where the city is located. ${ }^{22}$

\footnotetext{
${ }^{21}$ Data from the Census of Manufactures were not available for Superior (WI), Washington DC in 1909 and 1919, and for Flint (MI), Galveston (TX), Huntington (WV), Lexington (KY), McKeesport (PA), Pueblo (CO), Quincy (IL), and Roanoke (VA) in 1929.

${ }^{22}$ Predicted city population is calculated as $\hat{P}_{c s t}=P_{o p} p_{c, 1900} \cdot g_{t}^{-R}$, where $P o p_{c, 1900}$ is 1900 city population and $g_{t}^{-R} \equiv \frac{P o p_{t}^{-R}-P o p_{t-1}^{-R}}{P o p_{t-1}^{-R}}$ is urban population growth between Census year $t$ and $t-1$, constructed leaving out the region of city $c$.
} 
In online appendix D5, I also report results obtained when scaling immigration by either contemporaneous or 1900 city population. Standard errors are clustered at the MSA level, and MSA boundaries are fixed to 1940 in order to keep geography constant.

In my baseline specification, $I m m_{c s t}$ refers to the stock of European immigrants that entered the United States during the previous decade. I impose this sample restriction because, at that time, immigrants could apply for citizenship after 5 years (Shertzer, 2016). While historical accounts suggest that after 1910 immigrants' political engagement fell steadily (Kleppner, 1982), focusing on recently arrived immigrants allows me to more confidently interpret my findings on political outcomes as natives' reactions, rather than as the direct effect of immigrants' preferences. Results are unchanged when considering all immigrants, regardless of their arrival year and irrespective of their country of origin (online appendix D5).

\subsection{Instrument for Immigration}

A priori, we may expect immigrants to be attracted to cities with better job opportunities, or with more appealing tax-public spending bundles. Alternatively, immigrants might settle in otherwise declining cities, where house prices are lower. In either case, OLS estimates of equation (1) will likely be biased. To deal with this endogeneity problem, I construct a modified version of the shift-share instrument (Card, 2001). The instrument predicts the number of immigrants received by US cities over time by interacting 1900 settlements of different ethnic groups with subsequent migration flows from each sending region, excluding individuals that eventually settled in a given city's MSA. Formally, $I m m_{c s t}$ in (1) is instrumented with

$$
Z_{c s t}=\frac{1}{\hat{P}_{c s t}} \sum_{j} \alpha_{j c} O_{j t}^{-M}
$$

where $\hat{P}_{c s t}$ is predicted city population; $\alpha_{j c}$ is the share of individuals of ethnic group $j$ living in city $c$ in 1900; and $O_{j t}^{-M}$ is the number of immigrants from country $j$ that entered the US between $t$ and $t-1$, net of those that eventually settled in city $c$ 's MSA. ${ }^{23}$

The instrument constructed in equation (2) exploits two sources of variation: first, crosssectional variation in the share of individuals from each ethnic group living in different US cities in $1900\left(\alpha_{j c}\right)$; second, time-series variation induced by changes in the total number of immigrants from any sending region entering the United States in a given decade $\left(O_{j t}^{-M}\right)$. Figure C1 in online appendix C1 presents a simple example for three cities (Chicago, Milwaukee, and San Francisco) and two ethnic groups (Italians and Germans) to illustrate the variation underlying the instrument. Online appendix C2 describes the cross-sectional

\footnotetext{
${ }^{23}$ A similar "leave-out" strategy is also used in Burchardi et al. (2019).
} 
variation in 1900 immigrant settlements.

\subsubsection{Identifying Assumptions and Instrument Validity}

The key identifying assumption behind the instrument is that cities receiving more immigrants (from each sending area) before 1900 must not be on different trajectories for the evolution of economic and political conditions in subsequent decades (see also Borusyak et al., 2018, and Goldsmith-Pinkham et al., 2018). This assumption can be violated for two main reasons.

First, if the characteristics of cities that attracted early immigrants (from each sending country) had persistent, confounding effects on migration patterns as well as on changes in the outcomes of interest. I deal with this concern in two different ways. First, I show that the pre-period change in outcomes of interest is uncorrelated with subsequent changes in immigration predicted by the instrument. Second, I augment my baseline specification by: $i$ ) separately controlling for a time varying predicted measure of industrialization $;{ }^{24}$ and ii) including interactions between year dummies and several 1900 city characteristics that might have attracted more migrants (from each sending country) before 1900 and may have had a time varying effect on economic and political conditions across cities. I devote special attention to one such characteristic: 1900 immigrant population. ${ }^{25}$

By construction, the instrument predicts higher immigration to cities with a larger number of immigrants at baseline. If larger immigrant stocks also had an independent and time varying effect on city politics or labor markets, the identifying assumption would be violated. To address this concern, I start by flexibly controlling for interactions between year dummies and 1900 city and immigrant population. This implies that the effects of immigration are identified exploiting variation only in the ethnic composition of immigrant enclaves across cities, holding constant the size of their foreign born populations. Next, I include interactions between year dummies and the share of immigrants from each European country, $\alpha_{j c}$ in equation (2), to assuage concerns that specific immigrant groups (e.g. the Irish or the Italians) were more likely to settle in cities where they could influence city politics or alter economic conditions.

The second reason why the identifying assumption can be violated is that outmigration from each European country might not be independent of cross-city pull factors systematically related to 1900 settlers' country of origin (Borusyak et al., 2018). To deal with this potential threat, I construct an alternative version of the instrument where the number of immigrants from each European country entering the US is predicted exploiting solely vari-

\footnotetext{
${ }^{24}$ Following Sequeira et al. (2019), I construct this variable by interacting 1900 industry shares with national growth rates.

${ }^{25}$ See online appendix D1 for a detailed discussion of all other variables.
} 
ation generated by WWI and the Immigration Acts. I describe this strategy in detail in online appendix B1, and only briefly review the main steps in the next paragraph. ${ }^{26}$

As discussed in Section 2, WWI and the Immigration Acts induced large and exogenous variation both in the number and in the ethnic composition of immigrants arriving in the US over time. To directly exploit such variation, I start by taking stacked first differences of equation (1). Next, I replace the actual number of immigrants entering the US from each country $\left(O_{j t}^{-M}\right)$ with a measure of predicted immigration. For the 1910-1920 decade, the number of immigrants is predicted using WWI. I assume that if a country was not part of the Allies, its immigration was completely shut down, whereas if a country belonged to the Allies, there was no change in immigration. For the 1920-1930 decade, instead, $O_{j t}^{-M}$ in (2) is replaced with the sum of the yearly quota for country $j$ specified by the Immigration Acts of 1921 and 1924 .

An additional advantage of WWI and the Immigration Acts is that these shocks lowered substantially the serial correlation in migration flows to US cities over time. This is desirable since, as noted by Jaeger et al. (2018), one potential threat to shift-share instruments for the contemporaneous period is the high persistence of migration flows. In online appendix D4, I show that the national composition of immigration changed markedly between 1910 and 1930 (Figures D3 and D4), and that the estimation strategy proposed by Jaeger et al. (2018) to deal with the issue of serial correlation can be successfully implemented in this setting (Table D8).

\subsection{First Stage Results}

Table 2 presents first stage results for the relationship between actual and predicted immigration, after partialling out city and state by year fixed effects. In column 1, the dependent variable is the fraction of immigrants over actual city population, and the regressor of interest is the baseline instrument constructed in equation (2). Columns 2 and 3 replicate column 1 by dividing the actual and the predicted number of immigrants by, respectively, 1900 and predicted population. In all cases, the F-stat is very high, and there is a strong and significant relationship between the fraction of immigrants and the instrument. Figure 4 reports the graphical analogue of column 3, plotting the relationship between the fraction of immigrants and the instrument, after partialling out city and state by year fixed effects.

From column 3 onwards, both the actual and the predicted number of immigrants are scaled by predicted city population. Column 4 shows that the estimates are barely affected when aggregating the unit of analysis from cities to MSAs. Next, in columns 5 and 6, I

\footnotetext{
${ }^{26}$ Similarly to Sequeira et al. (2019), in online appendix B2, I also construct a measure of predicted immigration that only exploits temperature and precipitation shocks in origin countries.
} 
augment the baseline specification by including interactions between year dummies and the 1900 (log of) city and immigrants' population, and the 1904 (log of) value added by manufacture. Reassuringly, neither the economic nor the statistical significance of the coefficient is affected. Online appendix B shows that a similarly strong first stage relationship holds for the WWI and quotas instruments (Table B1) as well as for the weather shocks instrument (Table B2). Online appendix D5 further explores the robustness of the instrument(s) to the exclusion of potential outliers.

\section{The Political Effects of Immigration}

This section studies the political effects of immigration. First, cities cut tax rates and public spending in response to immigration (Section 5.1). Second, the inflow of immigrants reduced support for the pro-immigration party (i.e., Democrats) and increased the RepublicanDemocrat vote margin (Section 5.2). Third, immigration was associated with the election of more conservative representatives who were, in turn, more likely to vote in favor of the 1924 National Origins Act (Section 5.3). I conclude this section by arguing that these patterns are consistent with immigration triggering natives' backlash, and unlikely to be explained by alternative interpretations (Section 5.4).

\subsection{Tax Revenues and Public Spending}

At least until the Great Depression, US cities were responsible for the provision of public goods such as education, police, and spending on welfare or on infrastructure (e.g. roads, sewerage, etc.), while the federal (or the state) government played only a marginal role (Monkkonen, 1990). Also, since federal and state transfers were very limited, cities had to independently raise funds to finance their expenditures. More than $75 \%$ of cities' resources came from local taxes, with property taxes accounting for around $90 \%$ of total tax revenues (Fisher, 1996). Even though cities could issue debt, property tax rates represented the key (fiscal) policy variable at disposal of local public officials. If immigration lowered the desired level of redistribution and natives' utility from public goods consumption, one would expect to find larger reductions in tax revenues, and in particular in tax rates, in cities that received more immigrants.

Motivated by this discussion, in Table 3, I study the effects of immigration on public spending per capita (column 1) and tax rates (column 2). Throughout the paper, Panels A and B always present, respectively, OLS and 2SLS estimates. I also report the mean of the dependent variables at baseline as well as the KP F-stat for weak instruments at the bottom of all tables. In the interest of space, all robustness checks are summarized in Section 8, and 
then extensively described in online appendix D.

Immigration had a negative and statistically significant effect on both public spending per capita and tax rates. ${ }^{27}$ Coefficients in columns 1 and 2 of Panel B imply that a 5 percentage points (or, one standard deviation) increase in immigration reduced public spending per capita and property tax rates by, respectively, $5 \%$ and $7.5 \%$ relative to their 1910 average. $^{28}$ Next, exploiting the granularity of the data digitized from the Financial Statistics of Cities, Table A3 documents that the inflow of immigrants reduced total and property tax revenues per capita (columns 1 and 2). Consistent with a net reduction in tax revenues, lower tax rates were not compensated by a significant increase in either property values (columns 3 and 4) or in business taxes per capita (column 5).

If the political process whereby cities decided on redistribution were sticky, it is possible that the reduction in public spending and tax revenues per capita documented above was merely due to the mechanical effect of immigration on city population. The fact that cities reduced tax rates (Table 3, column 2) already suggests that this is unlikely to be the case. To more directly rule out this possibility, Table A4 shows that immigration reduced not only per capita (columns 1 and 2) but also total (columns 3 and 4) public spending and property tax revenues. Finally, Table A5 breaks down total expenditures across categories, and shows that spending cuts were larger for education (column 1) and for sanitation, sewerage and garbage collection (column 5), where inter-racial interactions are likely to be more salient and poorer immigrants would get larger implicit transfers.

Taken together, these findings suggest that immigration lowered (natives') demand for redistribution and induced cities to cut tax rates. One interpretation, consistent with several historical accounts (e.g. Higham, 1955; Leonard, 2016), is that the reduction in public goods provision reflected natives' backlash against immigrants, triggered by two different mechanisms. First, most immigrants, at least until 1920, came from relatively poor countries, and may have thus been perceived as a fiscal burden by natives. Second, ethnic diversity brought about by immigration might have lowered preferences for redistribution among natives (Easterly and Levine, 1997; Alesina et al., 1999). To sharpen this interpretation and rule out alternative explanations, in what follows, I turn to three additional political outcomes: electoral returns in Presidential elections (Section 5.2); the ideology of members of the House (Section 5.3.1); and, legislators' voting pattern on the 1924 National Origins Act (Section 5.3.2). ${ }^{29}$

\footnotetext{
${ }^{27}$ Data on property tax rates was not reported for the city of Pittsfield (MA) in 1930: for this reason, the number of observations in column 2 is 539, rather than 540 as in column 1.

${ }^{28}$ Interestingly, OLS and 2SLS estimates are very close to each other, suggesting that immigrants were unlikely to endogenously select cities that provided more redistribution.

${ }^{29}$ Alternative interpretations, such as the effects of immigration on the income distribution or the possibility that results in this section reflect political demands of previous immigrants, are discussed in Section 5.4.
} 


\subsection{Presidential Elections}

I now investigate how immigration affected electoral outcomes in receiving places. Since prior to 1951 systematic data on municipal elections do not exist (see de Benedictis-Kessner and Warshaw, 2016), I focus on Presidential elections between 1910 and 1930. Because electoral results are only available at the county level, I aggregate them at the MSA level, using 1940 MSA definitions. ${ }^{30}$ In column 3 of Table 3, I focus on the Democrats' vote share, again reporting OLS and 2SLS estimates in Panels A and B respectively.

The inflow of immigrants had a negative and statistically significant effect on support for Democrats, which was also economically relevant. The 2SLS coefficient in column 3 implies that a 5 percentage points increase in the fraction of immigrants reduced the Democrats' vote share by approximately 2 percentage points, or $5 \%$ relative to its 1910 mean. As shown in Table A6, the negative effect of immigration on the Democrats' vote share was accompanied by increasing support for third parties (column 2) and, to a lesser extent, for Republicans (column 1). Even if the coefficient in column 1 is not statistically significant, immigration had a strong, negative effect on the Democrats-Republicans margin (column 3). The estimates in column 3 (Panel B) imply that a 5 percentage points increase in the fraction of immigrants reduced the Democrats-Republicans margin by 2.9 percentage points, or by almost $15 \%$ relative to its 1910 mean - a sizeable effect.

While both Republicans and Democrats tried to win immigrants' support, between 1890 and 1940, most naturalized immigrants tended to vote for the Democratic party (Shertzer, 2016). ${ }^{31}$ The Irish are probably the most emblematic example, but this was true also of other ethnic or religious groups such as the Italians and the Catholics (Luconi, 1996; Kleppner, 1979). I examined the voting behavior of members of the House who represented the 180 cities in my sample between 1910 and 1930, finding that Democrats were significantly less likely to vote in favor of both the literacy test of 1917 and the Immigration Acts of 1921 and 1924. Even after controlling for state fixed effects, immigration, and a number of 1900 city characteristics, Democratic legislators were 20 percentage points more likely to vote against the immigration restrictions.

One interpretation of these results, consistent with similar estimates for the contemporaneous period (e.g. Dustmann et al., 2019; Halla et al., 2017), is that immigration triggered natives' backlash, reducing support for the pro-immigrant party, i.e. Democrats. These ideas are corroborated by historical accounts, which document that, during the Progressive Era, political reformers were often openly racists and directly involved in the eugenic soci-

\footnotetext{
${ }^{30}$ As discussed in Section 3, since Presidential elections are held every four years, I computed the average between the closest two elections after each Census year. Results are unchanged when taking the average from the two closest election years (see online appendix D8).

${ }^{31}$ Shertzer (2016) notes that the Democratic party was particularly appealing to foreign born because of its support for ethnic parochial schools and its opposition to the prohibition of alcohol.
} 
ety (Leonard, 2005, 2016). Moreover, the policy platform of Progressives was centered on radical urban reforms aimed at dismantling the political machines, whose main supporters were precisely the foreign born (e.g. Erie, 1990; Menes, 1999).

\subsection{Congressmen Ideology and Voting Behavior}

\subsubsection{Legislators' Ideology}

In column 4 of Table 3, I estimate the effects of immigration on the ideology of members of the House that represented the 180 cities in my sample in each Congress corresponding to the three Census years considered in my analysis, i.e. Congress 61 (1909-1911), Congress 66 (1919-1921), and Congress 71 (1929-1931). As discussed in Section 3, following Autor et al. (2017), I proxy for Congress members' ideology using the first dimension of the DW Nominate scores (Poole and Rosenthal, 1985; McCarty et al., 2006), and conduct the analysis at the city by congressional district level. ${ }^{32}$ While most of the city-congressional district combinations did not change between 1910 and 1930, redistricting between the $61^{\text {st }}$ and the $66^{\text {th }}$ Congress prevents the construction of a balanced panel including all cities in my sample. For this reason, I present results for both the unbalanced panel (Table 3) and the balanced panel that includes only cities not affected by redistricting between 1910 and 1920 (Table 4, column 2).

Focusing on the 2SLS coefficient reported in column 4 of Table 3, immigration had a positive and statistically significant effect on legislators' Nominate scores. ${ }^{33}$ This effect is also economically relevant: one standard deviation increase in the fraction of immigrants increases Nominate scores by approximately 0.25 standard deviations. ${ }^{34}$ These magnitudes are close to those in Autor et al. (2017) who estimate that a one standard deviation increase in trade exposure raises Nominate scores by 0.36 standard deviations.

Since the analysis is conducted at decennial frequency, most of the effect of immigration on legislators' Nominate scores comes from the election of new, more conservative representatives, rather than from changes in the ideology of incumbent politicians. ${ }^{35}$ Note that the increase in Nominate scores can come from the election of either more moderate (i.e. less liberal) Democrats or more conservative (i.e. less moderate) Republicans. Moreover,

\footnotetext{
${ }^{32}$ DW Nominate scores rank Congress members on an ideological scale from liberal to conservative using voting behavior on previous roll-calls, with higher (lower) values indicating a more conservative (liberal) ideology.

${ }^{33}$ The difference between OLS and 2SLS estimates indicates that immigrants endogenously settled in cities with a less hostile political environment. Column 2 of Table 4 confirms that results are similar when restricting the analysis to the balanced panel of cities to congressional districts.

${ }^{34}$ This number is obtained by multiplying the coefficient in column 4 (Panel B) by one standard deviation increase in immigration (0.05), and dividing it through the 1910 standard deviation in the DW Nominate scores $(0.372)$.

${ }^{35}$ Indeed, only in six cases, the same congressman in office in 1910 was also in office in 1930.
} 
since immigration had a strong impact on the Republican-Democrat vote margin (Table A6, column 3), the rise in Nominate scores may simply reflect a shift from moderate Democrats to moderate Republicans.

Columns 3 to 6 of Table 4 address these issues by studying if immigration affected the probability of electing, respectively, a liberal Democrat (column 3), a moderate Democrat (column 4), a moderate Republican (column 5), or a conservative Republican (column 6). Liberal (resp. moderate) Democrats are defined as legislators with a Nominate score below (resp. above) the median score for Democrats in the $61^{\text {st }}$ Congress. Likewise, a Republican legislator is classified as moderate (resp. conservative) if his Nominate score is below (resp. above) the median score for Republicans in the $61^{\text {st }}$ Congress. Similar results are obtained when classifying legislators relative to the four quartiles of the overall 1910 distribution of Nominate scores.

The replacement of more liberal Democrats with more moderate Democrats is not responsible for the rise in Nominate scores. In fact, even though the point estimate is not significant at conventional levels, there is a negative and quantitatively large effect of immigration on the probability of electing a moderate Democrat (column 4). Also, moderate Democrats are not replaced by moderate Republicans (column 5), but rather by conservative Republicans (column 6). Figure A8 visually displays this pattern, by plotting 2SLS coefficients reported in columns 3 to 6 of Table 4 . Interpreting the magnitude of these results, a 5 percentage points increase in immigration raises the probability of electing a conservative Republican by 12.5 percentage points. This effect is, once again, close to that estimated in Autor et al. (2017), who find that a one standard deviation increase in trade exposure increases the probability of electing a conservative Republican by 17.5 percentage points.

\subsubsection{Legislators' Voting Behavior and the National Origins Act}

In this section, I turn to the most direct proxy for anti-immigration sentiments, namely, the voting behavior of legislators on the 1924 National Origins Act. This bill, approved in 1924 as part of the Johnson-Reed Act, was the last of a series of attempts undertaken by US Congress to restrict immigration in the early twentieth century, and remained in place until 1965. While Congress approved the literacy test in 1917 and the Emergency Quota Act in 1921, it was not until the passage of the National Origins Act that the inflow of immigrants, especially from Eastern and Southern Europe, was effectively and permanently shut down. On the one hand, even though the literacy test was accompanied by a heated political debate (Goldin, 1994), by the time of its approval it was no longer binding. On the other, the Emergency Quota Act introduced only temporary measures, which were then 
made permanent (and more stringent) with the National Origins Act of $1924 .{ }^{36}$ For these reasons, I focus on the 1924 Immigration Act, and not on its predecessors.

As for Section 5.3.1, the analysis is conducted at the city by congressional district level, and attention is restricted to members of the House who represented the 180 cities in my sample during the Congress that approved the National Origins Act, i.e. Congress 68. Since I examine voting behavior at a specific point in time, redistricting is no longer an issue. However, precisely because of the cross-sectional nature of the analysis, results should be interpreted as suggestive. To indirectly gauge the size and the direction of the potential bias due to the impossibility of including city (and state by year) fixed effects, online appendix D8 (Table D16) replicates columns 1 to 6 of Table 4 using cross-sectional regressions. Reassuringly, results remain close to those reported in the main text.

Columns 7 and 8 of Table 4 document a positive and statistically significant relationship between a legislator's propensity to vote in favor of the National Origins Act and the 1910 to 1920 change in the fraction of immigrants received by the city (or cities) he represented. Column 7 only includes state fixed effects, while column 8 also controls for a number of 1900 characteristics, such as the fraction of Europeans and of African Americans, as well as congressmen party of affiliation. Even if the magnitude of the coefficient in column 8 is somewhat lower, the association between immigration and representatives' voting behavior remains positive and significant.

The coefficient in column 8 implies that, when comparing cities at the $25^{\text {th }}$ and $75^{\text {th }}$ percentiles of immigration, legislators representing the more exposed city were more likely to vote in favor of the National Origins Act by approximately 10 percentage points. This is a large, but not unreasonable effect, given that immigration was at that time (as it is today) at the forefront of the political debate. ${ }^{37}$

\subsection{Interpretation of Results}

So far, I presented three sets of results. First, cities cut tax rates and public spending in response to immigration. Second, the inflow of immigrants reduced support for the Democratic Party. Third, cities receiving more immigrants elected more conservative members of the House of Representatives who were in turn more likely to vote in favor of the 1924 National

\footnotetext{
${ }^{36}$ The 1921 Emergency Quota Act temporarily limited the number of immigrants from any given country that could enter the United States to $3 \%$ of the 1910 population of each ethnic group. With the 1924 National Origins Act, which made the 1921 Immigration Act permanent, the ceiling was lowered to $2 \%$ and the "base" year was moved to 1890. These two changes were undertaken to shut down the inflow of immigrants from "undesired" sources, such as Eastern and Southern Europe. As the Saturday Evening Post put it, "if there is one thing we need more than another it is a little discrimination in our immigration policy" (Spiro, 2009).

${ }^{37}$ Consider, for instance, that one standard deviation increase in the mortgage default rate during the 2007 Great Recession increased legislators' propensity to support the American Housing Rescue and Foreclosure Prevention Act by 12.6 percentage points (Mian et al., 2010).
} 
Origins Act. My interpretation of these patterns is that immigration generated political opposition among natives. In what follows, I discuss a number of alternative explanations, and argue that none of them can be entirely reconciled with my results.

First, at that time, after five years immigrants could apply for citizenship, becoming eligible to vote (Shertzer, 2016). If immigrants had different preferences relative to natives, changes in public spending and in tax rates may have resulted from the direct effect of immigrants' preferences rather than from natives' reactions. This idea, however, is inconsistent with electoral results presented in Sections 5.2 and 5.3, and with the historical literature documenting that, after 1910, the political involvement of foreign born fell steadily (Kleppner, 1982).

Second, it is possible that immigrants increased natives' income; if the (native) median voter became richer, demand for redistribution might have declined for reasons unrelated to political discontent (e.g. Meltzer and Richard, 1981). Note that both the election of more conservative Republicans and stronger support for anti-immigration legislation might be consistent with this alternative interpretation. Not only conservative Republicans were less likely to favor redistribution (relative to Democrats), but also, restricting the inflow of (poorer) immigrants may have been one way to limit redistribution. However, in contrast with this idea, Section 7 documents that, while Protestant and non-Protestant immigrants had similar effects on natives' employment and on economic activity, they triggered very different political reactions. Only Catholics and Jews - who were considered culturally further from natives relative to Protestants immigrants (Higham, 1955) - induced cities to limit redistribution, favored the election of more conservative legislators, and increased support for the 1924 National Origins Act.

A third possibility is that the political effects of immigration estimated above did indeed reflect backlash, but that this came from previously arrived immigrants rather than from natives. For instance, more established immigrants from Northern and Western Europe might have displayed a "cultural distaste" for more recent ones originating from Eastern and Southern Europe. Similarly, past immigrants might have been harmed economically due to labor market competition brought about by new migrants (Goldin, 1994). While this is a plausible interpretation, previous immigrants could have been pivotal in the political arena only if their preferences were aligned with those of natives. Said differently, previously arrived immigrants could have significantly influenced local politics only by forming a coalition with (at least some) natives. 


\section{The Economic Effects of Immigration}

This section first documents that immigrants increased natives' employment and fostered industrial production (Section 6.1). Next, it shows that, while immigration had no positive effect for workers closely substitutable for immigrants, it did not lower either employment or wages even for natives working in the most exposed sector to immigration, i.e. manufacturing (Section 6.2). It concludes with a discussion on the relationship between the economic and the political effects of immigration, arguing that natives' backlash was not predominantly driven by standard economic forces (Section 6.3).

\subsection{Natives' Employment and Economic Activity}

Perhaps the most obvious cause for natives' backlash is that immigrants increased labor market competition, depressing wages and raising unemployment among natives. To investigate this idea, Table 5 studies the economic effects of immigration. Restricting the sample to native men of working age, I focus on the employment to population ratio (column 1) and on log occupational scores (column 2). ${ }^{38}$

Starting from employment, both OLS (Panel A) and 2SLS (Panel B) coefficients are positive, statistically significant, and very close to each other. The point estimate in column 1 implies that a 5 percentage points increase in immigration raised natives' employment probability by 1.4 percentage points, or by $1.6 \%$ relative to the 1910 mean. Figure A9 displays the residual scatterplot for the reduced form estimates of the 2SLS specification and visually confirms the pattern emerging from column 1. Next, column 2 documents that immigration had a strong, positive effect on natives' occupational scores. ${ }^{39}$ Since occupational scores measure cross-occupational changes in earnings, this suggests that employment gains for natives were accompanied by occupational and skill upgrading.

These findings are in contrast with some results from the contemporary immigration literature such as Borjas (2003), Borjas and Katz (2007), and Dustmann et al. (2017) among others, who find a negative and sizeable effect of immigration on natives' labor market outcomes. They are also somewhat different from those of a number of contemporaneous cross-city studies that estimate a zero effect of immigration on natives' wages (e.g. Card, 2001, 2005). One reason for the difference between my findings and those from the more

\footnotetext{
${ }^{38}$ In my baseline specification, I consider men in the age range 15 to 65 , but results are robust to the use of different age thresholds (see also Carlana and Tabellini, 2018). As commonly done in the literature, the employment to population ratio is constructed as the number of native men (between 15 and 65) employed, over the total number of native men in the same age range.

${ }^{39}$ Differently from column 1, 2SLS estimates in column 2 are an order of magnitude larger than OLS. One possible interpretation is that, even though immigrants did not systematically select cities with stronger labor demand, they might have nonetheless moved to places with fewer opportunities for skill upgrading due to congestion costs (see also Sequeira et al., 2019).
} 
recent period is that, at the beginning of the twentieth century, the US economy had high potential for growth. Especially in manufacturing, labor scarcity was a recurrent problem (see the discussion in Section 2.2). In this context, by increasing the supply of cheap labor, immigration might have relaxed firms' (labor) constraints, allowing them to expand. Because of complementarity between immigrants and natives (Peri and Sparber, 2009), as firms grew, they also created more (relatively high skilled) jobs for natives.

To test these ideas, columns 3 and 4 of Table 5 investigate the impact of immigration on (the $\log$ of) value added per establishment and (the log of) establishment size. 2SLS estimates are positive, statistically significant, and economically large. They imply that a 5 percentage points increase in immigration raised industrial production and establishment size by approximately 10\%. Table A7 documents that similar results hold when using alternative measures of industrialization (columns 1 to 3 ), and that immigration had a large effect also on capital utilization and on firms' productivity (columns 4 and 5). ${ }^{40}$

When comparing the magnitudes in column 4 with those in column 1 of Table 5, it immediately appears that the growth in natives' employment is an order of magnitude smaller than that in establishment size. There are two complementary explanations for this. First, firms grew not only by hiring natives, but also, and importantly, by absorbing the immigration shock (Table A8, column 6). Second, establishment size increased because of firm consolidation, as immigration lowered the number of establishments (Table A7, column 6).

I refer the interested reader to online appendix E, where I present several additional results, including: $i$ ) a detailed analysis of immigrants-natives complementarities; $i i$ ) the margins (previously unemployed natives; increase in labor force participation of young natives; internal migration) through which natives' employment gains might have occurred; iii) the effects of immigration on employment of previous immigrants; $i v$ ) additional effects of immigration on firm productivity; and $v$ ) heterogeneous effects depending on city characteristics. $^{41}$

\subsection{Heterogeneous Effects and Manufacturing Wages}

Even if immigrants had, on average, positive economic effects, did they make any group of natives strictly worse off? Answering this question is important when interpreting the political results presented in Section 5. For instance, if immigrants increased labor market competition for low-skilled natives employed in manufacturing (the most exposed sector to

\footnotetext{
${ }^{40}$ Consistent with the literature, I proxy for capital utilitazion using the log of horsepower (results are robust to using the log of horsepower per capita or per establishment). To estimate the effects of immigration on productivity, I assumed a Cobb-Douglas production function with two factors of production, capital and (homogeneous) labor.

${ }^{41}$ Section 8 reports a summary of the robustness checks, which are described in detail in online appendix D.
} 
immigration), anti-immigration sentiments might reflect discontent arising from economic losers, who pushed for political and economic protection.

Table A8 shows that, consistent with economic theory, immigration did not increase employment for natives who were close substitutes for immigrants, like illiterate native whites (column 3) or African Americans (column 4). Similarly, immigration had no effect for natives employed as manufacturing laborers (column 5) - one of the most exposed occupations to immigrants' competition. ${ }^{42}$ However, even in highly exposed occupations and for groups that were close substitutes for immigrants, immigration did not significantly affect employment. As noted above, one explanation for this pattern is that manufacturing was able to expand, in turn absorbing the immigration-induced supply shock. Indeed, total employment in manufacturing increased almost one for one with immigration (Table A8, column 6).

Even if immigration had a positive effect on natives' employment, and no negative effect even for natives working in highly exposed sectors, it is nonetheless possible that it lowered wages at least for some workers. Unfortunately, the US Census of Population did not collect income or wage data prior to 1940, and so, this issue cannot be directly addressed using census data. While occupational scores can be used to proxy for natives' income, they do not capture within occupation changes in earnings. To overcome this limitation, in column 7 of Table A8, I estimate the effects of immigration on (log) average manufacturing wages, digitized from the Census of Manufactures. The coefficient is negative, but not statistically significant, with very large standard errors. Moreover, the implied magnitude is quite small: a 5 percentage points increase in the fraction of immigrants lowered wages in manufacturing by less than $1 \% .^{43}$

Summing up, the evidence presented in this section is inconsistent with the idea that immigration lowered wages or reduced employment even for workers in the most exposed sector, or whose skills were very similar to those of immigrants. While I do not observe the entire distribution of wages, since data from the Census of Manufactures do not distinguish between immigrants and natives, since new immigrants were closer substitutes for previously arrived immigrants than for natives, and because manufacturing was the most exposed sector to immigrants' competition, one can confidently interpret these results as a lower bound for the impact of immigration on natives' earnings.

\footnotetext{
${ }^{42}$ In 1910, recent immigrants were twice as likely as natives to be employed in unskilled occupations. Similarly, while around $21 \%$ of natives were working in manufacturing, almost $45 \%$ of immigrants were employed in this sector.

${ }^{43}$ This finding is somewhat in contrast with Goldin (1994), possibly because she focused on a different sample of cities and used a different empirical strategy.
} 


\subsection{Did Natives' Backlash Have Economic Roots?}

The analysis presented above weighs against the idea that political discontent was driven by purely economic factors. Not only immigration had a positive effect on natives' employment and occupational standing, but also, it did not reduce either employment or wages even for workers that were highly exposed to immigrants' competition. Yet, there exist a few other explanations for natives' political reactions that rest on economic grounds.

First, although immigration did not create clear economic losers among natives, it might have increased inequality. If individuals assess their life satisfaction relative to other (socioeconomic) groups in the society, natives' backlash can be explained by a "keep up with the Jones" type of argument. Lack of survey data for this historical period prevents me from directly addressing this issue. However, in the next section, I show that this interpretation is unlikely to hold: immigrants from different religious groups had very similar economic effects - likely moving the income distribution in the same way - and yet triggered very different political reactions.

A second, related possibility is that immigrants were able to upgrade faster than natives, in turn triggering natives' grievances, who may have felt threatened by "socially inferior" groups. Abramitzky et al. $(2012,2014)$ show that, contrary to the common wisdom, immigrants did not experience occupational mobility at a faster rate than natives, and that it often took multiple generations for immigrants' earnings to converge towards those of natives. Consistent with their findings, online appendix E3 documents that, if anything, immigration had a negative (although not statistically significant) effect on employment of previously arrived immigrants - an effect that disappears for immigrants who had spent more than 20 years in the US, and who were arguably more similar to natives (and thus less likely to be perfect substitutes for new migrants).

Third, it is possible that the positive economic effects of immigration did not reflect the creation of new jobs, but were instead simply due to the relocation of economic activity from one city to the others. In online appendix D2, I show that the economic effects of immigration are unchanged when aggregating the unit of analysis to the MSA, suggesting that any negative spillover had to operate outside the local labor market (e.g. at the state level). Exploring this possibility, online appendix D2 also tests whether immigration to other cities in the same state had any effect on a given city. Consistent with Sequeira et al. (2019), I find little evidence of negative spillovers from immigration to other cities, weighting against the possibility that political discontent was due to this channel.

Fourth, by increasing housing demand, immigration might have raised house prices and rents. While this would have benefitted homeowners, it would have nonetheless increased the 
cost of living for natives who did not own a house. ${ }^{44}$ These dynamics, rather than economic competition in the labor markets, may explain natives' hostile reactions. I provide two pieces of evidence against this possibility. First, as noted in Section 5.1, immigration did not have any significant effect on property values (Table A3). Second, online appendix E5 documents that immigration was not correlated with rents paid by natives. One possible explanation for this pattern is that immigrants represented a production amenity, but were perceived by natives as a consumption disamenity. ${ }^{45}$

Finally, immigration might have triggered natives' backlash by generating congestion costs in already crowded cities. Counter to this explanation, however, in online appendix E6, I show that political reactions were not systematically more pronounced in larger or in more densely populated cities.

\section{Backlash, Cultural Distance, and Ethnic Diversity}

If immigration was economically beneficial and did not reduce employment even for natives in highly exposed occupations, why did backlash emerge? In this section, exploiting variation in the "mix" of immigrants received by US cities over time, I show that cultural differences between immigrants and natives were responsible, at least in part, for natives' anti-immigration reactions.

\subsection{Cultural Distance: Religious Affiliation}

The historical evidence reviewed in Section 2.3 suggests that opposition to immigration during the Age of Mass Migration had deep cultural roots. Anti-immigration sentiments were often directed towards Jews and Catholics, whose values were perceived as a threat to the Puritan tradition prevailing in the US at that time (Higham, 1955; Spiro, 2009). One of the best examples for the strength of these sentiments is the revival of the Ku Klux Klan in the 1920s, which openly embraced an anti-Catholic and anti-Semitic ideology. Similarly, immigrants from non Anglo-Saxon and non English-speaking countries were the main target of the anti-immigration rhetoric at that time (Abramitzky et al., 2018; Leonard, 2016).

Motivated by these observations, I proxy for cultural distance between natives and immigrants using, respectively, religion and linguistic distance from English. Starting from religion, I estimate

$$
y_{c s t}=\gamma_{c}+\delta_{s t}+\beta_{1} I m m_{c s t}^{\text {Non-Prot }}+\beta_{2} I m m_{c s t}^{\text {Prot }}+u_{c s t}
$$

\footnotetext{
${ }^{44}$ In 1910, only $40 \%$ of natives living in the cities in my sample were homeowners.

${ }^{45}$ This idea is consistent with findings of several papers for both Europe and the US today (e.g. Card et al., 2012; Saiz and Wachter, 2011).
} 
where $I m m_{c s t}^{\text {Non-Prot }}$ (resp. $I m m_{c s t}^{\text {Prot }}$ ) is the fraction of Jews or Catholics (resp. Protestant) immigrants. In practice, equation (3) is estimated using two separate instruments, one for each religious group, constructed by summing predicted immigration from each sending region (see (2) in Section 4.2) across non-Protestant and Protestant countries respectively. I standardize the fraction of immigrants from non-Protestant and Protestant countries, so that coefficients $\beta_{1}$ and $\beta_{2}$ in (3) can be interpreted as the effect of one standard deviation increase in immigration from either religious group.

As a preliminary step, online appendix E7 shows that the economic effects of immigration were very similar across religious groups (see Figures E6 and E7). This is important because it rules out the possibility that any difference in natives' political reactions can be explained by differences in the economic effects of Protestant and non-Protestant immigrants. Next, in Table 6, I estimate (3), focusing on a set of political outcomes. Immigration had a negative and significant effect on taxes and spending only when immigrants came from nonProtestant countries (columns 1 to 4), whereas the coefficient on Protestant immigrants is quantitatively very small (or even positive, as in columns 1 and 2) and never statistically significant. Turning to electoral outcomes, even though both non-Protestant and Protestant immigrants seem to reduce the Democrat-Republican vote margin, results are statistically significant only for the former (column 5).

To more directly investigate the rise of anti-Catholic sentiments, in column 6, I study if the 1910-1930 (instrumented) change in Catholic and Protestant immigration had an effect on the percent of votes received by Alfred Smith in 1928 Presidential elections. Smith was the first Roman Catholic to run for presidency for the Democratic party, and historical accounts consider his religious affiliation one of the main reasons for his defeat (Slayton, 2001). The strong, negative association between Catholic (but not Protestant) immigrants and the percent of votes received by Smith is consistent with this view as well as with the idea that immigration triggered natives' backlash in receiving areas.

Finally, column 7 indicates that the increase in legislators' ideology was entirely due to non-Protestant immigration. Likewise, legislators' propensity to support the 1924 National Origins Act is strongly correlated with the 1910-1920 change in Catholic and Jewish immigration (column 8). Conversely, there is a negative, albeit not significant, correlation between the 1910-1920 change in the fraction of Protestant immigrants and the probability of voting in favor of the immigration restrictions. Consistent with these results, using data from local newspapers and Congressional speeches, D'Amico and Tabellini (2018) document that only Catholic and Jewish, but not Protestant, immigration increased the frequency of racially charged terms both in local media and in the Senate. 


\subsection{Linguistic Distance and Ethnic Diversity}

As an alternative proxy for cultural differences between immigrants and natives, I rely on the measure of linguistic distance constructed by Chiswick and Miller (2005), which is described in detail in online appendix E1. First, I compute the weighted average of immigrants' linguistic distance from English, $L D_{c s t}=\sum_{j}\left(s h_{c s t}^{j} \cdot L^{j}\right)$, where $s h_{c s t}^{j}$ is the share of ethnic group $j$ among the foreign born population of city $c$ in Census year $t$, and $L^{j}$ is the linguistic distance between country $j$ and English. Then, I re-estimate (1) using as main regressor of interest $L D_{c s t}$, always controlling for the (instrumented) fraction of immigrants and instrumenting the actual shares $\left(s h_{c s t}^{j}\right)$ with the same logic of the instrument in $(2) \cdot{ }^{46}$ To ease the interpretation of results, presented in Table 7 , I standardize $L D_{c s t}$ by subtracting its mean and dividing it by its standard deviation.

Consistent with findings in Table 6, higher linguistic distance is associated with larger reductions in taxes and public spending (columns 1 to 4 ). Moreover, and similarly to Table A5, the fall in spending is concentrated in education and, even though the point estimate is not statistically significant, in categories where inter-ethnic interactions are likely to be more salient (columns 5, 7, and 8). These results reject the idea that natives' reactions were primarily driven by economic considerations, since it was precisely immigration from linguistically far countries that boosted natives' occupational standing (Table E3 in online appendix E1).

Findings in Tables 6 and 7 are robust to simultaneously including a (standardized) index of average literacy among immigrants, thus reducing concerns that they might be capturing not only cultural, but also economic attributes of the foreign born (Table A9) ${ }^{47}$ Not surprisingly, since there are now three different endogenous regressors and three instruments, the precision of the estimates deteriorates relative to Table 7. Nonetheless, only linguistic distance has a significant effect on taxes and public spending. Moreover, except for columns 7 and 8 , the coefficient on linguistic distance is an order of magnitude larger (in absolute value) than that on literacy.

Differently from what one may expect, the correlation between the fraction of nonProtestant immigrants and the index of linguistic distance is as low as 0.05 , suggesting that findings for linguistic diversity are unlikely to merely replicate those for religious affiliation (see also online appendix E8). Finally, online appendix E9 provides evidence that the

\footnotetext{
${ }^{46}$ The estimated effect of immigration is not reported to save space. However, I always report the AP F-stat associated with its first stage.

${ }^{47}$ The literacy index was constructed as $L I T_{c s t}=\sum_{j}\left(s h_{c s t}^{j} \cdot L i t_{t}^{j}\right)$, where $L i t_{t}^{j}$ is the average literacy rate of males in working age from ethnic group $j$ who entered the US in the previous decade. To ease the interpretation of results, I multiplied $L I T_{c s t}$ by -1 , so that higher values of this index can be interpreted as lower average literacy among immigrants, and can be directly compared to $L D_{c s t}$. The correlation between $L D_{c s t}$ and $L I T_{c s t}$ is relatively low, with a value of 0.26 .
} 
(negative) effect of immigration on redistribution was larger when ethnic diversity among foreign born was higher. These findings are consistent with the large literature showing that ethnic diversity is associated with lower public goods provision and with more limited redistribution (e.g. Alesina et al., 1999; Beach and Jones, 2017; Luttmer, 2001).

It is possible that the negative relationship between redistribution and cultural or ethnic diversity merely reflects heterogeneity in preferences, and did not have any effect on social cohesion. However, as documented in Table 6, cultural diversity not only reduced public goods provision, but also generated a number of additional effects, such as the election of more conservative legislators and higher support for anti-immigration legislation. These patterns indicate that cultural diversity brought about by immigration caused hostile political reactions among natives, likely raising social conflict in receiving cities.

\section{Summary of Main Robustness Checks}

Online appendix D presents several robustness checks for results presented in the main paper. First, to address concerns that 1900 immigrants' settlements might be correlated with other city-specific characteristics that had a time varying effect on economic and political conditions: i) I show that there is no correlation between the pre-period change in any of the outcomes of interest and the change in immigration predicted by the instrument (Table D1); ii) I augment the baseline specification by separately controlling for predicted industrialization, and interacting year dummies with several 1900 city characteristics (Tables D2 to D4). Second, I document that the economic effects of immigration are unchanged when aggregating the analysis to the MSA level, and that there are no spillovers from cities in the same state (Table D5).

Third, to deal with the possibility that the 1900 share of immigrants were not independent of cross-city pull factors systematically related to 1900 settlers' country of origin (see Goldsmith-Pinkham et al., 2018), I replicate results interacting year dummies with the share of immigrants from each sending country (Figures D1 and D2). Fourth, to show that cityspecific, time-varying shocks did not endogenously affect immigration from specific European countries, I replicate the analysis using the WWI and quotas instruments and the weather shocks instrument constructed in online appendix B (Tables D6 and D7). Fifth, I present a number of results (Figures D3 and D4; Table D8) to show that, in this setting, the shift-share instrument is unlikely to conflate the long and the short run effects of immigration (Jaeger et al., 2018).

Sixth, I show that results are robust to: $i$ ) dropping potential outliers (Tables D9 to D11; Figure D5); ii) scaling the number of immigrants with different population measures (Table D12); iii) considering not only European or recently arrived immigrants (Table D13). 
Finally, I estimate non-parametric regressions to test for the possibility that immigration had non-linear effects (Figures D6 to D9), check that results are robust to using a specification in logs (Table D14), and replicate the analysis allowing for different assumptions on bias due to selection on observables and unobservables (Table D15), following the procedure outlined in Oster (2017).

\section{Conclusions}

Today, immigration is at the forefront of the political debate, and immigrants are increasingly opposed on both economic and cultural grounds. In this paper, I exploit variation in the number of immigrants received by US cities between 1910 and 1930 to jointly study the political and economic consequences of an episode of mass immigration. Using a leave-out version of the shift-share instrument (Card, 2001), I find that immigration triggered hostile political reactions, such as limiting redistribution, electing more conservative politicians, and raising support for the introduction of immigration restrictions.

Exploring the causes of such political reactions, I provide evidence that natives' backlash was unlikely to have economic roots. Not only immigration was on average beneficial to US cities, by increasing natives' employment and occupational standing and by fostering industrial production. But also, it did not induce losses even among natives working in sectors or occupations highly exposed to immigrants' competition. Exploiting variation in immigrants' background, I document that natives' backlash was increasing in the cultural distance between immigrants and natives, suggesting that opposition to immigration, at least in this context, was more likely to arise because of cultural, rather than economic, considerations.

Findings in this paper may be specific to the conditions prevailing in US cities in the early twentieth century. However, they may still be relevant for the design of policies aimed at dealing with the economic and the political effects of immigration today. My results suggest that, when cultural differences between immigrants and natives are large, opposition to immigration can arise even if immigrants are on average economically beneficial and do not create economic losers among natives. Thus, favoring the cultural assimilation of immigrants and reducing the (actual or perceived) distance between immigrants and natives may be at least as important as addressing the potential economic effects of immigration. 


\section{References}

Abramitzky, R. and L. P. Boustan (2017). Immigration in american economic history. Journal of Economic Literature 55(4).

Abramitzky, R., L. P. Boustan, and K. Eriksson (2012). Europe's tired, poor, huddled masses: Self-selection and economic outcomes in the age of mass migration. American Economic Review 102(5), 1832-56.

Abramitzky, R., L. P. Boustan, and K. Eriksson (2014). A nation of immigrants: Assimilation and economic outcomes in the age of mass migration. Journal of Political Economy 122(3), $467-506$.

Abramitzky, R., L. P. Boustan, and K. Eriksson (2018). Cultural assimilation during the two ages of mass migration. Working paper.

Ager, P. and C. W. Hansen (2017). Closing heaven's door: Evidence from the 1920s u.s. immigration quota acts. Working Paper.

Alesina, A., R. Baqir, and W. Easterly (1999). Public goods and ethnic divisions. The Quarterly Journal of Economics 114(4), 1243-1284.

Alesina, A. and E. La Ferrara (2005). Ethnic diversity and economic performance. Journal of economic literature $43(3), 762-800$.

Alesina, A., A. Miano, and S. Stantcheva (2018). Immigration and redistribution. NBER Working Paper.

Autor, D., D. Dorn, G. Hanson, and K. Majlesi (2017). Importing political polarization? the electoral consequences of rising trade exposure. NBER Working Paper 2263\%.

Bazzi, S. and M. Gudgeon (2016). Local government proliferation, diversity, and conflict. Technical report, Boston University-Department of Economics.

Beach, B. and D. B. Jones (2017). Gridlock: Ethnic diversity in government and the provision of public goods. American Economic Journal: Economic Policy 9(1), 112-36.

Becker, S. O. and T. Fetzer (2016). Does migration cause extreme voting. Technical report, Competitive Advantage in the Global Economy (CAGE).

Borjas, G. J. (2003). The labor demand curve is downward sloping: Reexamining the impact of immigration on the labor market. The quarterly journal of economics 118(4), 13351374 . 
Borjas, G. J. (2016). We Wanted Workers: Unraveling the Immigration Narrative. WW Norton \& Company.

Borjas, G. J. and L. F. Katz (2007). The evolution of the mexican-born workforce in the united states. In Mexican immigration to the United States, pp. 13-56. University of Chicago Press.

Borusyak, K., P. Hull, and X. Jaravel (2018). Quasi-experimental shift-share research designs. Working Paper.

Boustan, L. P. (2009). Competition in the promised land: Black migration and racial wage convergence in the north, 1940-1970. The Journal of Economic History 69(3), 755-782.

Burchardi, K. B., T. Chaney, and T. A. Hassan (2019). Migrants, ancestors, and investments. Review of Economic Studies, Forthcoming.

Card, D. (2001). Immigrant inflows, native outflows, and the local labor market impacts of higher immigration. Journal of Labor Economics 19(1), 22-64.

Card, D. (2005). Is the new immigration really so bad? The Economic Journal 115(507).

Card, D. (2009). Immigration and inequality. American Economic Review 99(2), 1-21.

Card, D., C. Dustmann, and I. Preston (2012). Immigration, wages, and compositional amenities. Journal of the European Economic Association 10(1), 78-119.

Carlana, M. and M. Tabellini (2018). Happily ever after: Immigration, natives' marriage, and fertility. Working Paper.

Chevalier, A., B. Elsner, A. Lichter, and N. Pestel (2018). Immigrant voters, taxation and the size of the welfare state. Working Paper.

Chiswick, B. R. and P. W. Miller (2005). Linguistic distance: A quantitative measure of the distance between english and other languages. Journal of Multilingual and Multicultural Development 26(1), 1-11.

Clemens, M. A., E. G. Lewis, and H. M. Postel (2018). Immigration restrictions as active labor market policy: Evidence from the mexican bracero exclusion. American Economic Review 108(6), 1468-87.

Clubb, J. M., W. H. Flanigan, and N. H. Zingale (1990). Partisan realignment: Voters, parties, and government in American history. 
Dahlberg, M., K. Edmark, and H. Lundqvist (2012). Ethnic diversity and preferences for redistribution. Journal of Political Economy 120(1), 41-76.

D'Amico, L. and M. Tabellini (2018). Immigration and cultural backlash in the age of mass migration: Evidence from local newspapers and congressional speeches. Working Paper.

de Benedictis-Kessner, J. and C. Warshaw (2016). Mayoral partisanship and municipal fiscal policy. The Journal of Politics 78(4), 1124-1138.

Dustmann, C., U. Schönberg, and J. Stuhler (2016). The impact of immigration: Why do studies reach such different results? Journal of Economic Perspectives 30(4), 31-56.

Dustmann, C., U. Schonberg, and J. Stuhler (2017). Labor supply shocks, native wages, and the adjustment of local employment. The Quarterly Journal of Economics 132(1), 435.

Dustmann, C., K. Vasiljeva, and A. P. Damm (2019). Refugee migration and electoral outcomes. Review of Economic Studies, Forthcoming 19, 16.

Easterly, W. and R. Levine (1997). Africa's growth tragedy: policies and ethnic divisions. The Quarterly Journal of Economics 112(4), 1203-1250.

Erie, S. P. (1990). Rainbow's end: Irish-Americans and the dilemmas of urban machine politics, 1840-1985, Volume 15. Univ of California Press.

Fisher, G. W. (1996). The worst tax?: A history of the property tax in America. University Press of Kansas.

Foerster, R. F. (1924). The Italian emigration of our times, Volume 20. Harvard University Press.

Foged, M. and G. Peri (2016). Immigrants' effect on native workers: New analysis on longitudinal data. American Economic Journal: Applied Economics 8(2), 1-34.

Goldin, C. (1994). The political economy of immigration restriction in the united states, 1890 to 1921. In The regulated economy: A historical approach to political economy, pp. 223-258. University of Chicago Press.

Goldsmith-Pinkham, P., I. Sorkin, and H. Swift (2018). Bartik instruments: What, when, why, and how. Working paper, National Bureau of Economic Research.

Greenwood, M. J. and Z. Ward (2015). Immigration quotas, world war i, and emigrant flows from the united states in the early 20th century. Explorations in Economic History 55, $76-96$. 
Halla, M., A. F. Wagner, and J. Zweimüller (2017). Immigration and voting for the far right. Journal of the European Economic Association 15(6), 1341-1385.

Hatton, T. J. and J. G. Williamson (1998). The age of mass migration: Causes and economic impact. Oxford University Press on Demand.

Hatton, T. J. and J. G. Williamson (2006). International migration in the long run: Positive selection, negative selection, and policy. In Labor Mobility and the World Economy, pp. 1-31. Springer.

Higgs, R. (1971). The transformation of the American economy, 1865-1914: An essay in interpretation. Wiley New York.

Higham, J. (1955). Strangers in the land: Patterns of American nativism, 1860-1925. Rutgers University Press.

Jaeger, D. A., J. Ruist, and J. Stuhler (2018). Shift-share instruments and the impact of immigration. Working paper, National Bureau of Economic Research.

Jones, M. A. (1992). American immigration. University of Chicago Press.

Keeling, D. (1999). The transportation revolution and transatlantic migration, 1850-1914. Research in Economic History 19, 39-74.

Kennedy, P. J. F. (1964). A nation of immigrants. New York: Harper \& Row Publishers.

Kleppner, P. (1979). The Third Electoral System 1853-1892: Parties, Voters, and Political Cultures, Volume 2. University of North Carolina Press.

Kleppner, P. (1982). Who voted?: The dynamics of electoral turnout, 1870-1980. Praeger Publishers.

Lafortune, J., J. Tessada, and E. Lewis (2019). People and machines: A look at the evolving relationship between capital and skill in manufacturing 1860-1930 using immigration shocks. Review of Economics and Statistics, Forthcoming.

Leonard, T. C. (2005). Retrospectives: Eugenics and economics in the progressive era. Journal of Economic Perspectives 19(4), 207-224.

Leonard, T. C. (2016). Illiberal reformers: race, eugenics, and American economics in the Progressive Era. Princeton University Press.

Lewis, E. (2011). Immigration, skill mix, and capital skill complementarity. The Quarterly Journal of Economics 126(2), 1029-1069. 
Lewis, E. and G. Peri (2015). Immigration and the economy of cities and regions. Handbook of Regional and Urban Economics 5, 625-685.

Lewis, J. B., B. DeVine, L. Pitcher, and K. C. Martis (2013). Digital boundary definitions of united states congressional districts, 1789-2012. Data file and code book.

Luconi, S. (1996). Machine politics and the consolidation of the roosevelt majority: The case of italian americans in pittsburgh and philadelphia. Journal of American Ethnic History, $32-59$.

Luttmer, E. F. (2001). Group loyalty and the taste for redistribution. Journal of political Economy 109(3), 500-528.

McCarty, N., K. T. Poole, and H. Rosenthal (2006). Polarized America: The dance of ideology and unequal riches. MIT Press.

Meltzer, A. H. and S. F. Richard (1981). A rational theory of the size of government. Journal of political Economy 89(5), 914-927.

Menes, R. (1999). The effect of patronage politics on city government in american cities, 1900-1910. Working Paper 6975, National Bureau of Economic Research.

Mian, A., A. Sufi, and F. Trebbi (2010). The political economy of the us mortgage default crisis. American Economic Review 100(5), 1967-98.

Monkkonen, E. H. (1990). America becomes urban: the development of US cities $\& 5$ towns, 1780-1980. Univ of California Press.

Monras, J. (2018). Immigration and wage dynamics: Evidence from the mexican peso crisis.

Oster, E. (2017). Unobservable selection and coefficient stability: Theory and evidence. Journal of Business \& Economic Statistics, 1-18.

Ottaviano, G. I. and G. Peri (2012). Rethinking the effect of immigration on wages. Journal of the European economic association 10(1), 152-197.

Peri, G. and C. Sparber (2009). Task specialization, immigration, and wages. American Economic Journal: Applied Economics 1(3), 135-69.

Poole, K. T. and H. Rosenthal (1985). A spatial model for legislative roll call analysis. American Journal of Political Science, 357-384.

Ruggles, S., K. Genadek, R. Goeken, J. Grover, and M. Sobek (2015). Integrated public use microdata series: Version 6.0 [dataset]. Minneapolis: University of Minnesota. 
Saiz, A. and S. Wachter (2011). Immigration and the neighborhood. American Economic Journal: Economic Policy 3(2), 169-188.

Sequeira, S., N. Nunn, and N. Qian (2019). Immigrants and the making of america. Review of Economic Studies, Forthcoming.

Shertzer, A. (2016). Immigrant group size and political mobilization: Evidence from european migration to the united states. Journal of Public Economics 139, 1-12.

Slayton, R. A. (2001). Empire statesman: The rise and redemption of Al Smith. Simon and Schuster.

Sniderman, P. M., L. Hagendoorn, and M. Prior (2004). Predisposing factors and situational triggers: Exclusionary reactions to immigrant minorities. American Political Science Review 98(01), 35-49.

Spiro, J. (2009). Defending the master race: conservation, eugenics, and the legacy of Madison Grant. UPNE.

Stuart, B. A. and E. J. Taylor (2016). Social interactions and location decisions: Evidence from us mass migration. Unpublished working paper.

Swift, E. K., R. G. Brookshire, D. T. Canon, E. C. Fink, J. R. Hibbing, B. D. Humes, M. J. Malbin, and K. C. Martis (2000). Database of congressional historical statistics [computer file]. Ann Arbor, MI: Inter-university Consortium for Political and Social Research.

Tabellini, M. (2018). Racial heterogeneity and local government finances: Evidence from the great migration. Working Paper.

Watts, S. (2009). The people's tycoon: Henry Ford and the American century. Vintage. 
Table 1. Summary Statistics

\begin{tabular}{|c|c|c|c|c|c|c|}
\hline VARIABLES & Mean & Median & St. Dev. & Min & $\operatorname{Max}$ & Obs. \\
\hline \multicolumn{7}{|c|}{$\underline{\text { Panel A. City Demographics }}$} \\
\hline Fr. all immigrants & 0.152 & 0.149 & 0.097 & 0.007 & 0.518 & 540 \\
\hline Fr. recent immigrants & 0.042 & 0.026 & 0.044 & 0.001 & 0.343 & 540 \\
\hline $\begin{array}{l}\text { Recent immigrants over } \\
1900 \text { population }\end{array}$ & 0.074 & 0.048 & 0.078 & 0.002 & 0.678 & 540 \\
\hline City population $(1,000 \mathrm{~s})$ & 190.1 & 76.05 & 510.4 & 30.20 & 6,930 & 540 \\
\hline \multicolumn{7}{|c|}{$\underline{\text { Panel B. Economic Outcomes }}$} \\
\hline Employed & 0.858 & 0.889 & 0.071 & 0.648 & 0.952 & 538 \\
\hline Log occupational scores & 3.263 & 3.265 & 0.047 & 3.080 & 3.427 & 538 \\
\hline $\begin{array}{l}\text { Value added per } \\
\text { establishment }\end{array}$ & 87.66 & 65.92 & 74.47 & 7.945 & 556.3 & 525 \\
\hline Establishment size & 52.86 & 43.09 & 37.98 & 5.465 & 229.9 & 525 \\
\hline \multicolumn{7}{|c|}{$\underline{\text { Panel C. Political Outcomes }}$} \\
\hline $\begin{array}{l}\text { Tax rate per } 1,000 \$ \text { of } \\
\text { assessed valuation }\end{array}$ & 29.42 & 25.78 & 16.48 & 6.450 & 114.3 & 539 \\
\hline Expenditures per capita & 14.57 & 12.89 & 7.336 & 3.443 & 49.99 & 540 \\
\hline Democrats' vote share & 0.482 & 0.465 & 0.189 & 0.103 & 0.967 & 378 \\
\hline DW Nominate Score & 0.178 & 0.334 & 0.338 & -0.578 & 0.991 & 470 \\
\hline
\end{tabular}

\section{Table 2. First Stage}

\begin{tabular}{|c|c|c|c|c|c|c|}
\hline & \multicolumn{6}{|c|}{ Dep. Variable: Fraction of Immigrants } \\
\hline & (1) & (2) & (3) & (4) & (5) & (6) \\
\hline $\mathrm{Z}$ & $\begin{array}{c}0.840 * * * \\
(0.056)\end{array}$ & $\begin{array}{c}0.968 * * * \\
(0.064)\end{array}$ & $\begin{array}{c}0.999 * * * \\
(0.059)\end{array}$ & $\begin{array}{c}0.948 * * * \\
(0.104)\end{array}$ & $\begin{array}{c}0.893 * * * \\
(0.091)\end{array}$ & $\begin{array}{c}0.900 * * * \\
(0.081)\end{array}$ \\
\hline 1900 population & & $\mathrm{X}$ & & & & \\
\hline Predicted population & & & $\mathrm{X}$ & & & \\
\hline MSA analysis & & & & $\mathrm{X}$ & & \\
\hline Year by 1900 Log & & & & & $\begin{array}{l}\text { City and imm } \\
\text { pop }\end{array}$ & $\begin{array}{l}\text { Value added } \\
\text { manuf. }\end{array}$ \\
\hline F-stat & 225.1 & 226.7 & 288.3 & 82.65 & 96.48 & 124.8 \\
\hline Cities & 180 & 180 & 180 & 127 & 180 & 176 \\
\hline Observations & 540 & 180 & 540 & 379 & 540 & 528 \\
\hline
\end{tabular}


Table 3. The Political Effects of Immigration

\begin{tabular}{|c|c|c|c|c|}
\hline Dependent Variable: & $\begin{array}{l}\text { (1) } \\
\text { Public Spending per } \\
\text { Capita }\end{array}$ & $\begin{array}{c}\text { (2) } \\
\text { Property tax rate }\end{array}$ & $\begin{array}{c}(3) \\
\text { Democrats' Vote Share }\end{array}$ & $\begin{array}{c}(4) \\
\text { DW Nominate Score }\end{array}$ \\
\hline \multicolumn{5}{|l|}{ Panel A: OLS } \\
\hline Fr. Immigrants & $\begin{array}{l}-5.958 \\
(3.900)\end{array}$ & $\begin{array}{c}-28.49 * * * \\
(10.60)\end{array}$ & $\begin{array}{c}-0.528 * * * \\
(0.119)\end{array}$ & $\begin{array}{c}0.745 \\
(0.514)\end{array}$ \\
\hline \multicolumn{5}{|l|}{ Panel B: 2SLS } \\
\hline Fr. Immigrants & $\begin{array}{l}-8.699 * \\
(4.453)\end{array}$ & $\begin{array}{l}-29.44^{*} \\
(16.95)\end{array}$ & $\begin{array}{c}-0.404 * * * \\
(0.141)\end{array}$ & $\begin{array}{l}1.658 * * \\
(0.808)\end{array}$ \\
\hline F-stat & 288.3 & 292.7 & 83.14 & 23.11 \\
\hline Mean of dep var. & 12.16 & 19.75 & 0.490 & 0.165 \\
\hline Observations & 540 & 539 & 378 & 460 \\
\hline $\begin{array}{l}\text { Note: columns } 1 \text { and } 2 \text { pres } \\
\text { public spending per capita } \\
\text { Presidential elections, and th } \\
\text { the dependent variable is the } \\
66 \text {, and } 71 \text {, for the } 180 \text { citie } \\
\text { immigrants arrived in the pr } \\
\text { text). F-stat refers to the K-F } \\
\text { (column 3) or congressional } \\
\text { (column 4) level, in parenth }\end{array}$ & $\begin{array}{l}\text { balanced panel of the } 180 \mathrm{~L} \\
\text { d property tax rate for } \$ 1,0 \\
\text { des the balanced panel of the } \\
\text { of DW Nominate scores for } \\
\text { my sample. Panels A and B } \\
\text { ver predicted city population, } \\
\text { instrument. Regressions in } \mathrm{c} \\
\text { column } 4 \text { ) and state by year } \mathrm{f} \\
; * * p<0.05 ; * \mathrm{p}<0.1 \text {. }\end{array}$ & $\begin{array}{l}\text { ith at least } 30,000 \text { resid } \\
\text { ssed valuation in colum } \\
\text { politan statistical areas ( } \\
\text { of the House of Represen } \\
\text { LS and } 2 S L S \text { results for } \\
\text { trumented using the base } \\
\text { and } 2 \text { include city and sta } \\
\text { ts. Robust standard error }\end{array}$ & $\begin{array}{l}\text { each Census year } 1910,1920 \text {, } \\
\text { column } 3 \text {, the dependent varial } \\
\text { containing at least one of the } 18 \\
\text {, for the panel of city-to-congress } \\
\text { aseline specification (equation (1) } \\
\text { rsion of the instrument constructe } \\
\text { year fixed effects, while regressio } \\
\text { tered at the MSA (for columns } 1\end{array}$ & $\begin{array}{l}\text { 1930. The dependent variable } \\
\text { is the Democrats vote share } \\
\text { cities in my sample. In column } \\
\text { nal district units for Congress } 61 \\
\text { Fr. Immigrants is the fraction o } \\
\text { in Section } 4.2 \text { (see (2) in the mai } \\
\text { in columns } 3 \text { and } 4 \text { include MS } \\
\text { 3) or congressional district to cit }\end{array}$ \\
\hline
\end{tabular}

Table 4. Congressmen Ideology and the National Origins Act of 1924

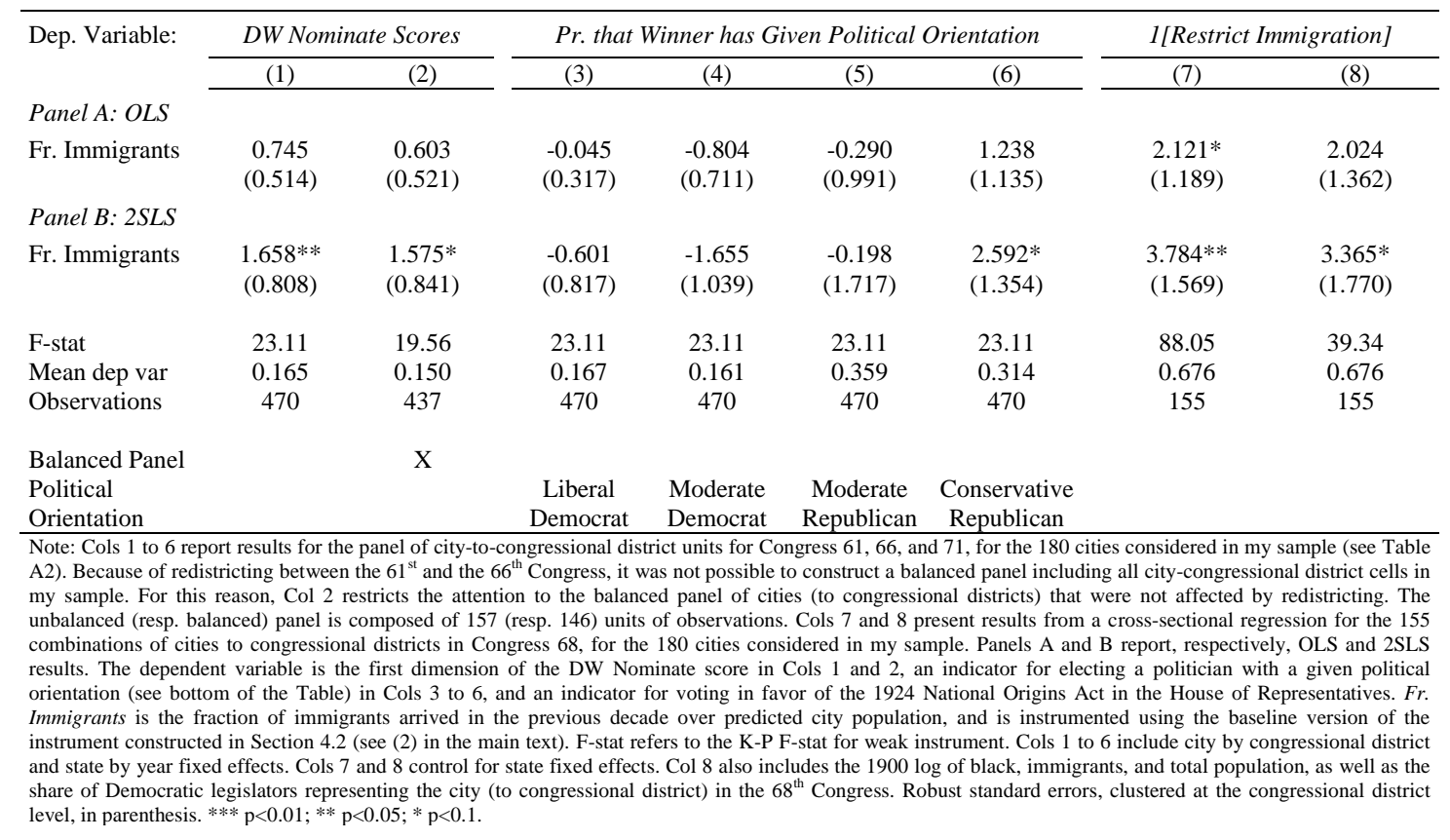


Table 5. The Economic Effects of Immigration

\begin{tabular}{|c|c|c|c|c|}
\hline \multirow[b]{2}{*}{ Dependent Variable: } & \multicolumn{2}{|c|}{ Natives' Outcomes } & \multicolumn{2}{|c|}{ Economic Activity } \\
\hline & $\begin{array}{c}\text { (1) } \\
\text { Employment to } \\
\text { Population Ratio }\end{array}$ & $\begin{array}{c}(2) \\
\text { Log Occupational } \\
\text { Scores }\end{array}$ & $\begin{array}{c}\text { (3) } \\
\text { Log Value Added per } \\
\text { Establishment }\end{array}$ & $\begin{array}{c}\text { (4) } \\
\text { Log Establishment } \\
\text { Size }\end{array}$ \\
\hline \multicolumn{5}{|l|}{ Panel A: $O L S$} \\
\hline Fr. Immigrants & $\begin{array}{c}0.287 * * * \\
(0.043)\end{array}$ & $\begin{array}{c}0.000 \\
(0.053)\end{array}$ & $\begin{array}{c}2.057 * * * \\
(0.703)\end{array}$ & $\begin{array}{c}2.195^{* * * *} \\
(0.614)\end{array}$ \\
\hline \multicolumn{5}{|l|}{ Panel B: $2 S L S$} \\
\hline Fr. Immigrants & $\begin{array}{c}0.299 * * * \\
(0.064)\end{array}$ & $\begin{array}{c}0.097 * * * \\
(0.036)\end{array}$ & $\begin{array}{c}2.889 * * * \\
(0.954)\end{array}$ & $\begin{array}{c}2.532 * * * \\
(0.815)\end{array}$ \\
\hline F-stat & 251.3 & 251.3 & 270.5 & 270.5 \\
\hline Mean of dep var. & 0.911 & $\begin{array}{c}3.245 \\
538\end{array}$ & $\begin{array}{c}3.820 \\
525\end{array}$ & $\begin{array}{c}3.539 \\
525\end{array}$ \\
\hline $\begin{array}{l}\text { Note: this table presents rest } \\
\text { in the age range } 15 \text { to } 65 \mathrm{wl} \\
\text { the Census of Manufactu } \\
\text { column 2. Occupational sco } \\
\text { added per establishment i } \\
\text { Fr. Immigrants is the fractio } \\
\text { in Section } 4.2 \text { (see (2) in the } \\
\text { at the MSA level, in parenth }\end{array}$ & $\begin{array}{l}\text { panel of the } 180 \text { US citie } \\
\text { in schools (columns } 1 \text { a } \\
\text { and } 1929 \text {. The depen } \\
\text { by IPUMS, and assign to } \\
\text { the log of establishmer } \\
\text { rived in the previous dec } \\
\text { refers to the K-P F-stat f } \\
* \text { p }<0.05 \text {; } * \text { p }<0.1 \text {. }\end{array}$ & $\begin{array}{l}\text { ast } 30,000 \text { residents in ea } \\
\text { amns } 3 \text { and } 4 \text { further restr } \\
\text { le is natives' employmen } \\
\text { lual the median income o } \\
\text { olumn 4. Panels A and } \mathrm{I} \\
\text { redicted city population, } \\
\text { trument. All regressions i }\end{array}$ & $\begin{array}{l}\text { s year } 1910,1920 \text {, and } 1930, \mathrm{r} \\
\text { mple to city-year observations } \\
\text { ulation ratio in column 1, and } \\
\text { category in } 1950 \text {. The deper } \\
\text { OLS and 2SLS results for the } \\
\text { trumented using the baseline } \\
\text { ity and state by year fixed effe }\end{array}$ & $\begin{array}{l}\text { ting the attention to native } \mathrm{m} \\
\text { which data were reported } \\
\text { es' log occupational scores } \\
\text { variable is the log of val } \\
\text { ine specification (equation ( } 1 \\
n \text { of the instrument construct } \\
\text { obust standard errors, cluster }\end{array}$ \\
\hline
\end{tabular}

\section{Table 6. Immigration and Religion}

\begin{tabular}{|c|c|c|c|c|c|c|c|c|}
\hline Dep. Var. & $\begin{array}{c}\text { (1) } \\
\text { Total tax } \\
\text { revenues PC }\end{array}$ & $\begin{array}{c}\text { (2) } \\
\text { Property tax } \\
\text { revenues PC }\end{array}$ & $\begin{array}{c}\text { (3) } \\
\text { Property tax } \\
\text { rate }\end{array}$ & $\begin{array}{c}\text { (4) } \\
\text { Public } \\
\text { spending PC }\end{array}$ & $\begin{array}{c}(5) \\
\text { Dem-Rep. } \\
\text { margin }\end{array}$ & $\begin{array}{c}\text { (6) } \\
\text { Smith's pct. } \\
\text { votes }\end{array}$ & $\begin{array}{c}\text { (7) } \\
\text { DW Nominate } \\
\text { Scores }\end{array}$ & $\begin{array}{c}\text { (8) } \\
1[\text { Restrict } \\
\text { Immigration] }\end{array}$ \\
\hline \multicolumn{9}{|l|}{ Panel A: OLS } \\
\hline Fr. Non-Prot. & $\begin{array}{l}-0.519 \\
(0.329)\end{array}$ & $\begin{array}{l}-0.449 \\
(0.278)\end{array}$ & $\begin{array}{c}-1.235 * * * \\
(0.477)\end{array}$ & $\begin{array}{c}-0.320^{*} \\
(0.180)\end{array}$ & $\begin{array}{c}-0.039 * * * \\
(0.007)\end{array}$ & $\begin{array}{c}-0.085^{* * *} \\
(0.015)\end{array}$ & $\begin{array}{c}0.035 \\
(0.025)\end{array}$ & $\begin{array}{c}0.098 * * * \\
(0.036)\end{array}$ \\
\hline Fr. Prot. & $\begin{array}{c}0.406 \\
(0.339)\end{array}$ & $\begin{array}{c}0.277 \\
(0.326)\end{array}$ & $\begin{array}{l}-0.077 \\
(0.722)\end{array}$ & $\begin{array}{c}0.154 \\
(0.313)\end{array}$ & $\begin{array}{c}0.023 \\
(0.016)\end{array}$ & $\begin{array}{l}0.050^{*} \\
(0.030)\end{array}$ & $\begin{array}{c}-0.009 \\
(0.017)\end{array}$ & $\begin{array}{c}-0.057 \\
(0.046)\end{array}$ \\
\hline
\end{tabular}

Panel B: 2SLS

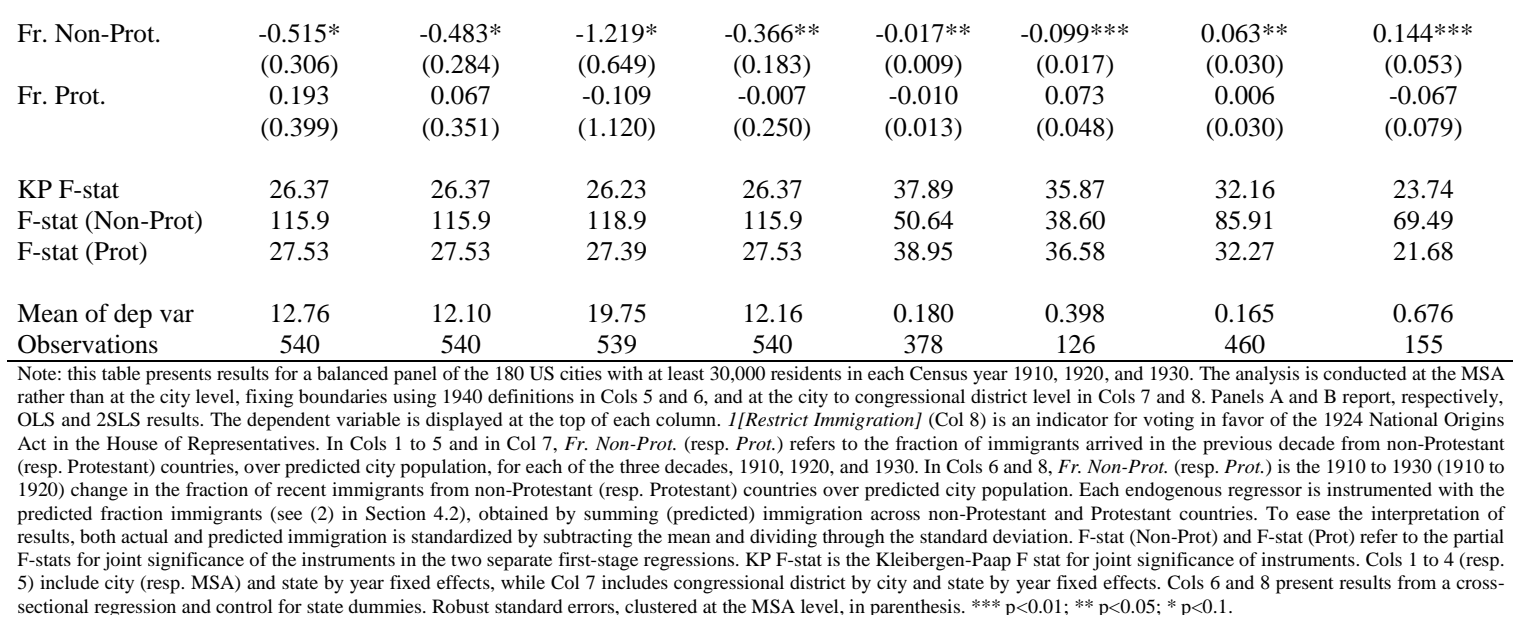


Table 7. Linguistic Distance and Redistribution

\begin{tabular}{|c|c|c|c|c|c|c|c|c|}
\hline Dep. Var. & $\begin{array}{c}1) \\
\text { Total tax } \\
\text { revenues PC }\end{array}$ & $\begin{array}{c}\text { (2) } \\
\text { Property tax } \\
\text { revenues PC }\end{array}$ & $\begin{array}{l}\text { (3) } \\
\text { Property tax } \\
\text { rate }\end{array}$ & $\begin{array}{c}\text { (4) } \\
\text { Public } \\
\text { spending PC }\end{array}$ & $\begin{array}{c}\text { (5) } \\
\text { Education }\end{array}$ & $\begin{array}{c}(6) \\
\text { Police }\end{array}$ & $\begin{array}{c}(7) \\
\text { Charities and } \\
\text { Hospitals }\end{array}$ & $\begin{array}{c}(8) \\
\text { Sanitation }\end{array}$ \\
\hline \multicolumn{9}{|l|}{ Panel A: OLS } \\
\hline Ling. Distance & $\begin{array}{l}-0.361^{*} \\
(0.205)\end{array}$ & $\begin{array}{l}-0.346 \\
(0.212)\end{array}$ & $\begin{array}{l}-1.485^{*} \\
(0.840)\end{array}$ & $\begin{array}{l}-0.213 \\
(0.160)\end{array}$ & $\begin{array}{l}-0.050 \\
(0.060)\end{array}$ & $\begin{array}{l}-0.032 \\
(0.021)\end{array}$ & $\begin{array}{l}-0.010 \\
(0.039)\end{array}$ & $\begin{array}{l}-0.045 \\
(0.029)\end{array}$ \\
\hline \multicolumn{9}{|l|}{ Panel B: $2 S L S$} \\
\hline Ling. Distance & $\begin{array}{l}-0.875^{*} \\
(0.468)\end{array}$ & $\begin{array}{c}-0.809^{*} \\
(0.458)\end{array}$ & $\begin{array}{l}-2.308 \\
(1.598)\end{array}$ & $\begin{array}{l}-0.519^{*} \\
(0.301)\end{array}$ & $\begin{array}{l}-0.199^{*} \\
(0.117)\end{array}$ & $\begin{array}{l}-0.013 \\
(0.042)\end{array}$ & $\begin{array}{l}-0.119 \\
(0.084)\end{array}$ & $\begin{array}{l}-0.053 \\
(0.052)\end{array}$ \\
\hline KP F-stat & 21.02 & 21.02 & 21.47 & 21.02 & 21.14 & 21.02 & 16.31 & 21.02 \\
\hline F-stat (Imm.) & 123.1 & 123.1 & 124.7 & 123.1 & 106.9 & 123.1 & 101.6 & 123.1 \\
\hline F-stat (Ling.) & 50.38 & 50.38 & 53.48 & 50.38 & 48.05 & 50.38 & 34.06 & 50.38 \\
\hline Mean of dep var & 12.76 & 12.10 & 19.75 & 12.16 & 4.250 & 1.338 & 0.635 & 1.129 \\
\hline Observations & 540 & 540 & 539 & 540 & 534 & 540 & 516 & 540 \\
\hline $\begin{array}{l}\text { Note: this Table pre } \\
\text { report, respectively, } \\
\text { capita on the catego } \\
7.2 \text {, instrumented us } \\
\text { significance of instr } \\
\text { regressions include } \\
\text { effects Robust stann }\end{array}$ & $\begin{array}{l}\text { results for a } \\
\text { and } 2 \text { SLS re } \\
\text { ed at the top } \\
\text { redicted shar } \\
\text { s. F-stat (Im } \\
\text { ain effect of } \\
\text { rors, clustere }\end{array}$ & $\begin{array}{l}\text { ced panel of } \\
\text { The depen } \\
\text { column. Tl } \\
\text { immigrants } \\
\text { nd F-stat (L } \\
\text { igration (in } \\
\text { the MSA lev }\end{array}$ & $\begin{array}{l}80 \text { US citie } \\
\text { rariable is d } \\
\text { in regressor } \\
\text { teach send } \\
\text { refer to the } \\
\text { ented with } \\
\text { parenthesis }\end{array}$ & $\begin{array}{l}\text { th at least } 30 \text {, } \\
\text { ayed at the to } \\
\text { nterest is the } \\
\text { region obtain } \\
\text { ial F-stats for } \\
\text { baseline shift } \\
\text { p }<0.01: * * \mathrm{p}\end{array}$ & $\begin{array}{l}\text { residents it } \\
\text { each colur } \\
\text { ndardized) } \\
\text { rom (2) in } \\
\text { nt significa }\end{array}$ & $\begin{array}{l}\text { Census y } \\
\text { Cols } 5 \text { to } \\
\text { ed averag } \\
4.2 \text {. F-s } \\
\text { the instru }\end{array}$ & $\begin{array}{l}10,1920 \text {, and } 19 \\
\text { dependent varia } \\
\text { tistic distance cor } \\
\text { the Kleibergen-P } \\
\text { in the two separ } \\
\text { trol for city and }\end{array}$ & $\begin{array}{l}\text { Panels A and B } \\
\text { is spending per } \\
\text { ucted in Section } \\
\text { F stat for joint } \\
\text { first-stages. All } \\
\text { te by year fixed }\end{array}$ \\
\hline
\end{tabular}

\section{Figure 1. Immigrants as a Percent of US Population}

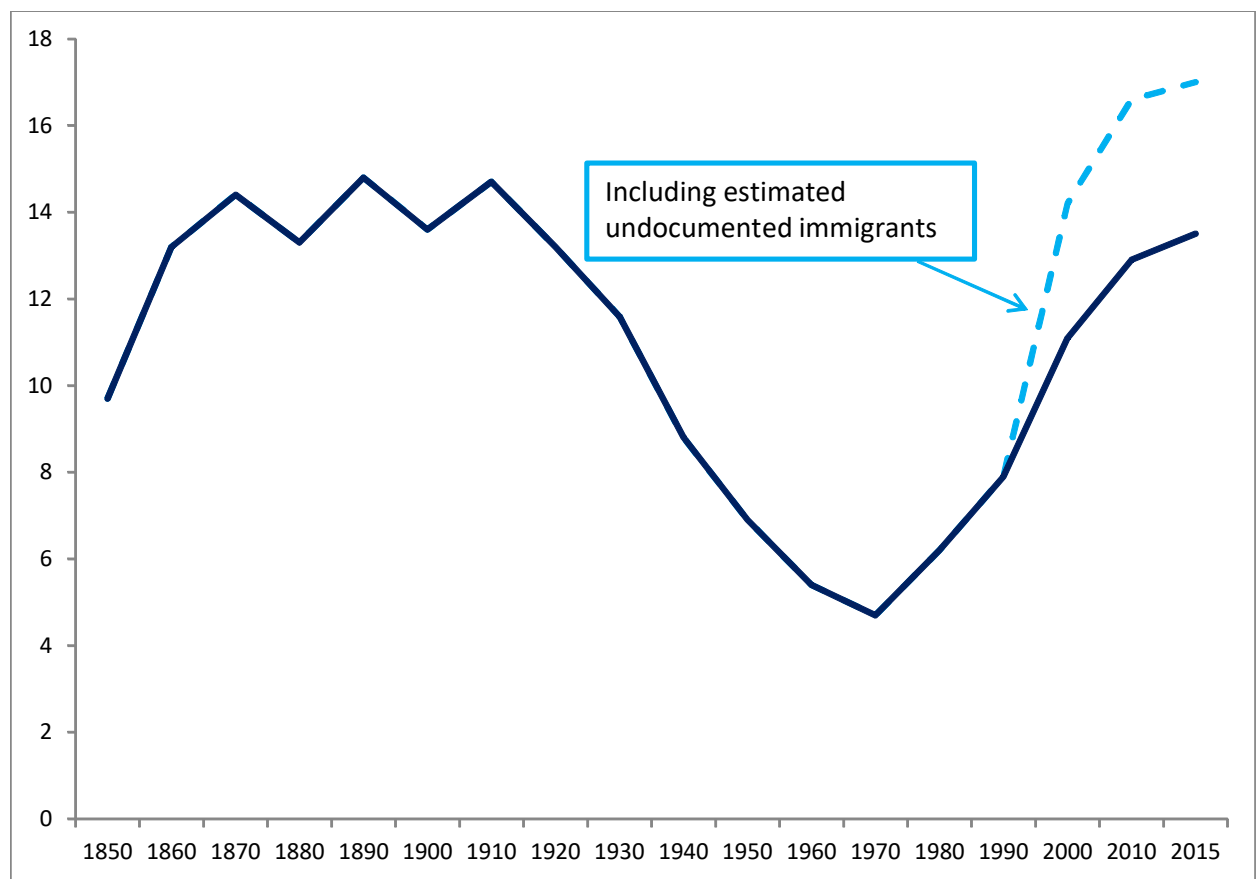

Note: The solid line shows the number of legal immigrants as a percent of US population. The dashed line includes also the estimated number of illegal immigrants, available from 2000 onwards. Source: the number of legal immigrants comes from the Migration Policy Institute, while the number of illegal immigrants was taken from the Pew Research Center tabulations 
Figure 2. Share of Foreign Born in the United States, by Region

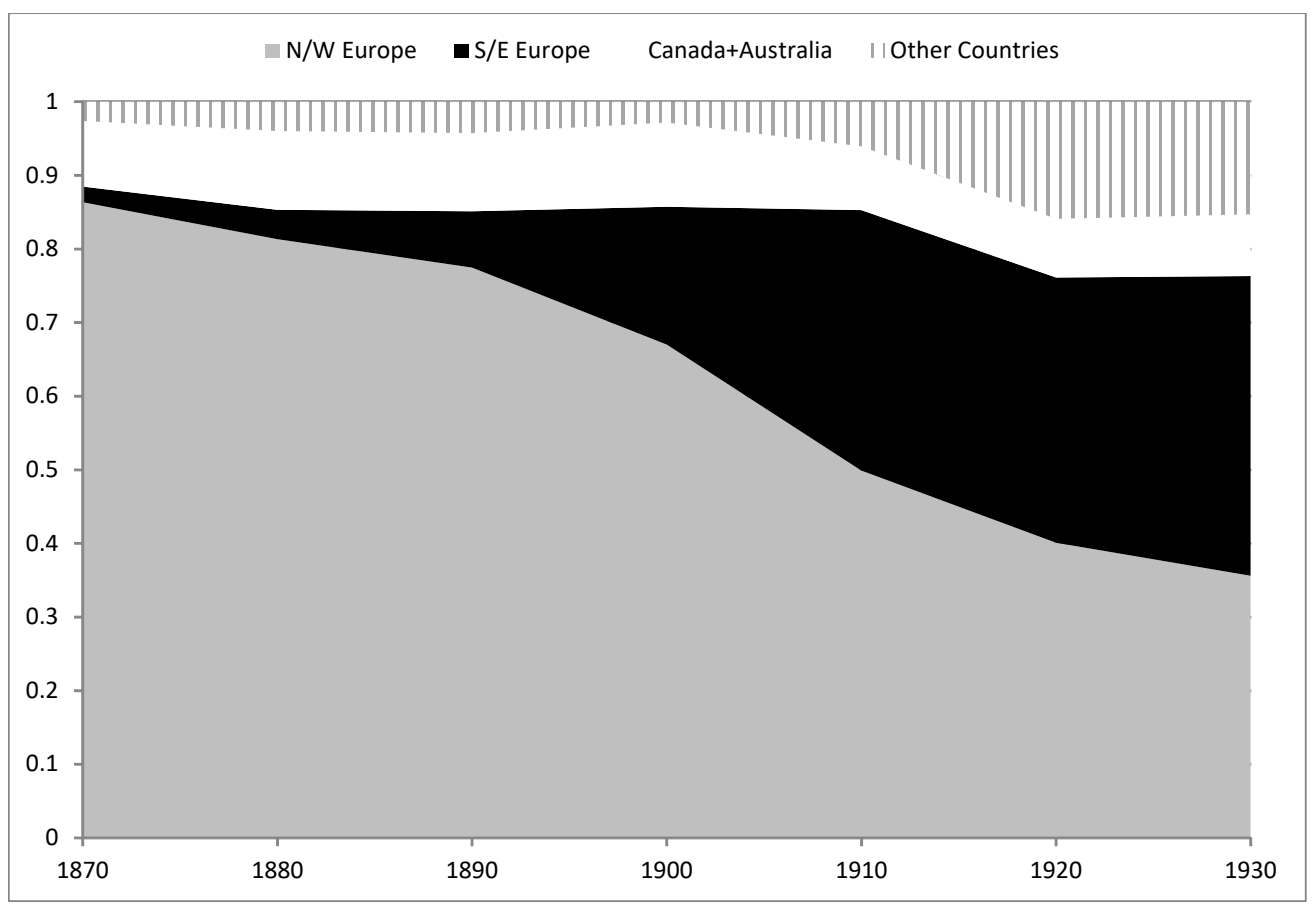

Note: Share of immigrant stock living in the United States, by sending region and by decade. Source: Author's calculations from IPUMS sample of US Census (Ruggles et al., 2015).

\section{Figure 3. Total Number of Immigrants (in Thousands)}

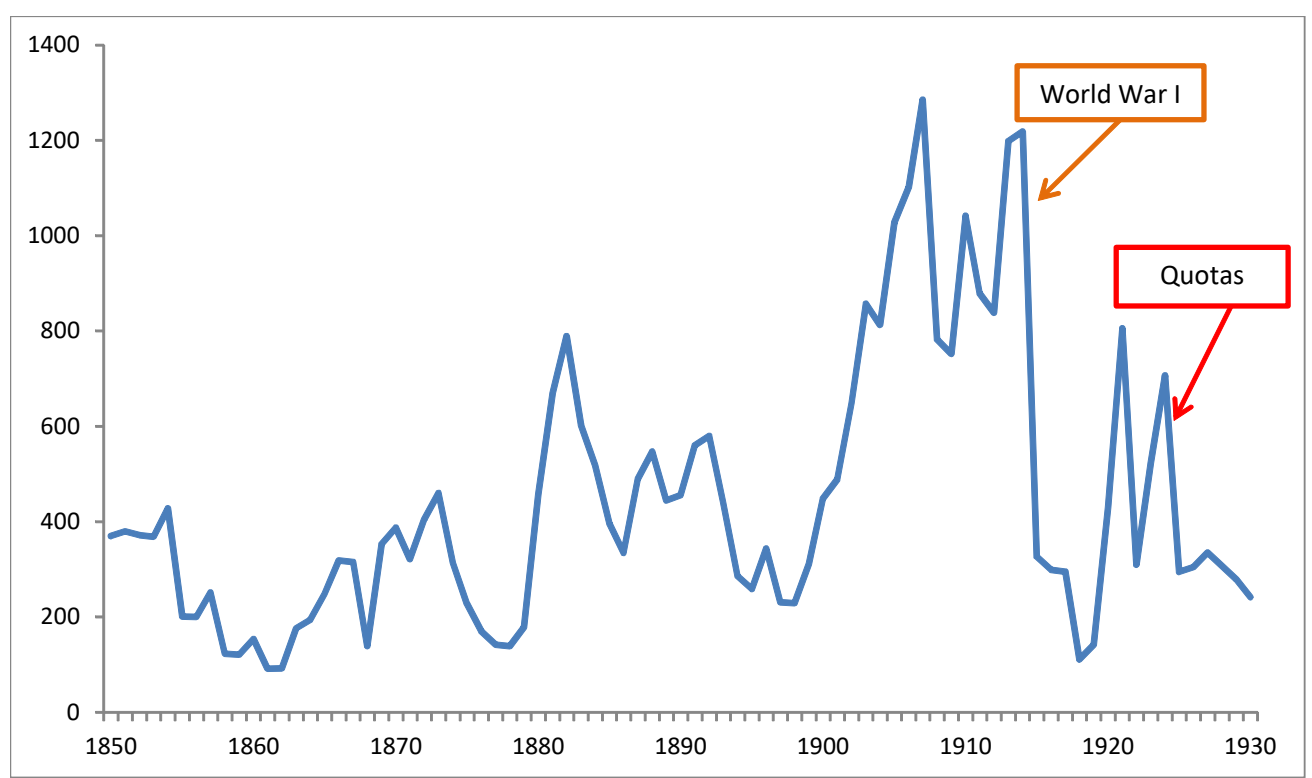

Note: Annual inflow of immigrants to the United States (1850-1930). Source: Migration Policy Institute. 


\section{Figure 4. First Stage: Actual vs Predicted Immigration}

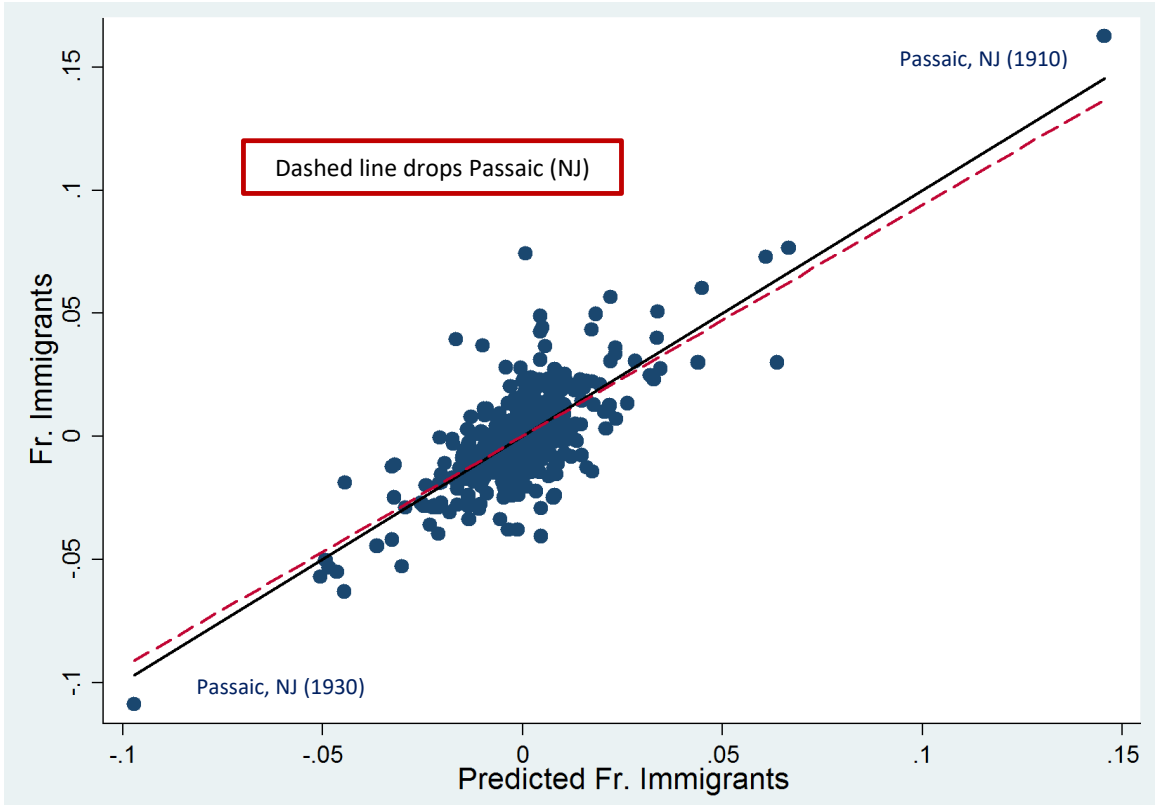

Note: the $y$-axis (resp. x-axis) reports the actual (resp. predicted) number of immigrants over predicted city population in each of the three Census years, 1910, 1920, and 1930. Each point in the scatter diagram represents the residual change in a city's actual and predicted fraction of immigrants after partialling out city and year by state fixed effects. The predicted number of immigrants is constructed as discussed in Section 4.2 in the text (see (2)). Predicted city population is obtained by multiplying 1900 city population with average urban growth, excluding that of the Census division where a city is located. The solid line shows the regression coefficient for the full sample (coefficient $=0.999$, standard error $=0.059$ ). The dotted (red) line shows the regression coefficient obtained when dropping the city of Passaic, NJ (coefficient $=0.940$, standard error $=0.068$ ). 


\section{ONLINE APPENDIX}

\section{Contents}

$\begin{array}{ll}\text { A Supplementary Tables and Figures } & 45\end{array}$

B WWI, Quotas, and Weather Shocks Instruments $\quad 56$

$\begin{array}{lc}\text { C Graphical Example and Immigrants' Settlements } & 63\end{array}$

$\begin{array}{ll}\text { D Robustness Checks } & 67\end{array}$

$\begin{array}{ll}\text { E Additional Results } & 92\end{array}$ 


\section{A Supplementary Tables and Figures}

Table A1. European Regions

\begin{tabular}{cc}
\hline UK & Russia \\
Ireland & Eastern Europe (Yugoslavia, Czechoslovakia, etc.) \\
Denmark & Austria-Hungary \\
Finland & Switzerland \\
Norway & France \\
Sweden & Belgium-Netherlands \\
Germany & Greece-Portugal-Spain \\
Poland & Italy \\
\hline
\end{tabular}

Note: this table lists the European sending regions used to construct the instrument for immigration. 


\section{Table A2. City List}

\begin{tabular}{|c|c|c|c|}
\hline Akron, $\mathrm{OH}$ & Elizabeth, NJ & McKeesport, PA & Saint Joseph, MO \\
\hline Albany, NY & Elmira, NY & Memphis, TN & Saint Louis, MO \\
\hline Allentown, PA & Erie, PA & Milwaukee, WI & Saint Paul, MN \\
\hline Altoona, PA & Evansville, IN & Minneapolis, MN & Salem, MA \\
\hline Amsterdam, NY & Everett, MA & Mobile, AL & San Antonio, TX \\
\hline Atlanta, GA & Fall River, MA & Montgomery, AL & San Diego, CA \\
\hline Atlantic City, NJ & Fitchburg, MA & Mount Vernon, NY & San Francisco, CA \\
\hline Auburn, NY & Flint, MI & Nashville, TN & Savannah, GA \\
\hline Augusta, GA & Fort Wayne, IN & New Bedford, MA & Schenectedy, NY \\
\hline Baltimore, MD & Fort Worth, TX & New Britain, CT & Scranton, PA \\
\hline Bay City, MI & Galveston, TX & New Castle, PA & Seattle, WA \\
\hline Bayonne, NJ & Grand Rapids, MI & New Haven, CT & Sioux City, IA \\
\hline Berkeley, CA & Hamilton, $\mathrm{OH}$ & New Orleans, LA & Somerville, MA \\
\hline Binghamton, NY & Harrisburg, PA & New York, NY & South Bend, IN \\
\hline Birmingham, AL & Hartford, CT & Newark, NJ & Spokane, WA \\
\hline Boston, MA & Haverhill, MA & Newton, MA & Springfield, IL \\
\hline Bridgeport, CT & Hoboken, NJ & Niagara Falls, NY & Springfield, MA \\
\hline Brockton, MA & Holyoke, MA & Norfolk, VA & Springfield, MO \\
\hline Buffalo, NY & Houston, TX & Oakland, CA & Springfield, $\mathrm{OH}$ \\
\hline Butte, MT & Huntington, WV & Oklahoma City, OK & Superior, WI \\
\hline Cambridge, MA & Indianapolis, IN & Omaha, NE & Syracuse, NY \\
\hline Camden, NJ & Jackson, MI & Oshkosh, WI & Tacoma, WA \\
\hline Canton, $\mathrm{OH}$ & Jacksonville, FL & Pasadena, CA & Tampa, FL \\
\hline Cedar Rapids, IA & Jamestown, NY & Passaic, NJ & Taunton, MA \\
\hline Charleston, SC & Jersey City, NJ & Paterson, NJ & Terre Haute, IN \\
\hline Charlotte, NC & Johnstown, PA & Pawtucket, RI & Toledo, $\mathrm{OH}$ \\
\hline Chattanooga, TN & Joliet, IL & Peoria, IL & Topeka, KS \\
\hline Chelsea, MA & Kalamazoo, MI & Perth Amboy, NJ & Trenton, NJ \\
\hline Chester, PA & Kansas City, KS & Philadelphia, PA & Troy, NY \\
\hline Chicago, IL & Kansas City, MO & Pittsburgh, PA & Utica, NY \\
\hline Cincinnati, $\mathrm{OH}$ & Knoxville, TN & Pittsfield, MA & Washington, DC \\
\hline Cleveland, $\mathrm{OH}$ & La Crosse, WI & Portland, ME & Waterbury, CT \\
\hline Columbus, $\mathrm{OH}$ & Lancaster, PA & Portland, OR & Wheeling, WV \\
\hline Covington, $\mathrm{KY}$ & Lansing, MI & Portsmouth, VA & Wichita, KS \\
\hline Dallas, TX & Lawrence, MA & Providence, RI & Wilkes-Barre, PA \\
\hline Davenport, IA & Lexington, $\mathrm{KY}$ & Pueblo, CO & Williamsport, PA \\
\hline Dayton, $\mathrm{OH}$ & Lima, $\mathrm{OH}$ & Quincy, IL & Wilmington, DE \\
\hline Decatur, IL & Lincoln, NE & Quincy, MA & Woonsocket, RI \\
\hline Denver, CO & Little Rock, AR & Racine, WI & Worcester, MA \\
\hline Des Moines, IA & Los Angeles, CA & Reading, PA & Yonkers, NY \\
\hline Detroit, MI & Louisville, KY & Richmond, VA & York, PA \\
\hline Dubuque, IA & Lowell, MA & Roanoke, VA & Youngstown, $\mathrm{OH}$ \\
\hline Duluth, MN & Lynn, MA & Rochester, NY & \\
\hline East Orange, NJ & Macon, GA & Rockford, IL & \\
\hline East St. Louis, IL & Malden, MA & Sacramento, CA & \\
\hline El Paso, TX & Manchester, NH & Saginaw, MI & \\
\hline
\end{tabular}


Table A3. Tax Revenues and Property Values

\begin{tabular}{|c|c|c|c|c|c|}
\hline Dep. Var. & $\begin{array}{c}(1) \\
\text { Total tax revenues PC }\end{array}$ & $\begin{array}{c}\text { (2) } \\
\text { Property tax revenues } \\
\text { PC }\end{array}$ & $\begin{array}{c}\text { (3) } \\
\text { Property values PC }\end{array}$ & $\begin{array}{c}\text { (4) } \\
\text { Property values over } \\
1910 \text { pop }\end{array}$ & $\begin{array}{c}\text { (5) } \\
\text { Business Taxes } \\
\text { PC }\end{array}$ \\
\hline \multicolumn{6}{|l|}{ Panel A: OLS } \\
\hline Fr. Immigrants & $\begin{array}{l}-8.525 \\
(6.490)\end{array}$ & $\begin{array}{l}-8.060 \\
(5.515)\end{array}$ & $\begin{array}{l}372.4 \\
(740.6)\end{array}$ & $\begin{array}{c}240.3 \\
(562.1)\end{array}$ & $\begin{array}{c}0.268 \\
(1.677)\end{array}$ \\
\hline \multicolumn{6}{|l|}{ Panel B: $2 S L S$} \\
\hline Fr. Immigrants & $\begin{array}{l}-11.15 \\
(6.982)\end{array}$ & $\begin{array}{l}-11.08^{*} \\
(6.467)\end{array}$ & $\begin{array}{l}294.6 \\
(915.3)\end{array}$ & $\begin{array}{c}518.3 \\
(740.9)\end{array}$ & $\begin{array}{c}1.843 \\
(1.604)\end{array}$ \\
\hline F-stat & 288.3 & 288.3 & 288.3 & 288.3 & 288.3 \\
\hline Mean of dep var & 12.53 & 12.04 & 715.9 & 715.9 & 0.889 \\
\hline Cities & 180 & 180 & 180 & 180 & 180 \\
\hline Observations & 540 & 540 & 540 & 540 & 540 \\
\hline $\begin{array}{l}\text { Note: this Table pre } \\
\text { report, respectively, } \\
\text { (resp. over } 1910 \text { pop } \\
\text { over predicted city } \\
\text { the K-P F-stat for w } \\
\text { p }<0.01 ; * * p<0.05 ;\end{array}$ & $\begin{array}{l}\text { or a balanced panel of the } \\
\text { S results. The dependent } \\
13 \text { (resp. Col 4); and busin } \\
\text { d is instrumented using the } \\
\text { t. All regressions include c }\end{array}$ & $\begin{array}{l}0 \text { US cities with at least } \\
\text { iable is total (resp. prope } \\
\text { s taxes per capita in Col } \\
\text { aseline version of the in } \\
\text { and state by year fixed }\end{array}$ & $\begin{array}{l}000 \text { residents in each } \\
\text { tax revenues per capi } \\
r \text {. Immigrants is the } \mathrm{fr} \\
\text { ment constructed in } \mathrm{S} \\
\text { ts. Robust standard er }\end{array}$ & $\begin{array}{l}\text { S year 1910, 1920, and } \\
\text { Col } 1 \text { (resp. Col 2); pro } \\
\text { of immigrants arrived } \\
4.2 \text { (see (2) in the mai } \\
\text { lustered at the MSA le }\end{array}$ & $\begin{array}{l}\text { 30. Panels A and B } \\
\text { ty values per capita } \\
\text { the previous decade } \\
\text { ext). F-stat refers to } \\
\text { in parenthesis. } * * *\end{array}$ \\
\hline
\end{tabular}

\section{Table A4. Public Spending and Tax Revenues: Per Capita vs Total}

\begin{tabular}{|c|c|c|c|c|}
\hline \multirow[t]{3}{*}{ Dep. Variable: } & $\begin{array}{c}\text { Public } \\
\text { Spending }\end{array}$ & $\begin{array}{c}\text { Property Tax } \\
\text { Revenues }\end{array}$ & $\begin{array}{c}\text { Public } \\
\text { Spending }\end{array}$ & $\begin{array}{c}\text { Property Tax } \\
\text { Revenues }\end{array}$ \\
\hline & \multicolumn{2}{|c|}{ Per Capita } & \multicolumn{2}{|c|}{ Total } \\
\hline & $(1)$ & $(2)$ & (3) & (4) \\
\hline Fr. Immigrants & $\begin{array}{l}-8.699 * \\
(4.453)\end{array}$ & $\begin{array}{c}-11.08 * \\
(6.467)\end{array}$ & $\begin{array}{c}-452.9 * * * \\
(96.70)\end{array}$ & $\begin{array}{c}-491.4 * * * \\
(104.5)\end{array}$ \\
\hline F-stat & 288.3 & 288.3 & 288.3 & 288.3 \\
\hline Observations & 540 & 540 & 540 & 540 \\
\hline \multicolumn{5}{|c|}{$\begin{array}{l}\text { Note: this table presents } 2 \text { SLS results for a balanced panel of the } 180 \text { US cities with at least } 30,000 \text { residents in each Census } \\
\text { year } 1910,1920 \text {, and } 1930 \text {. The dependent variable is public spending and property tax revenues per capita in columns } 1 \\
\text { and } 2 \text {. In columns } 3 \text { and } 4 \text {, the dependent variable is total public spending and total property tax revenues (in } 100,000 \\
\text { dollars). Fr. Immigrants is the fraction of immigrants arrived in the previous decade over predicted city population, and is } \\
\text { instrumented using the baseline version of the instrument constructed in Section } 4.2 \text { (see ( } 2 \text { ) in the main text). F-stat refers } \\
\text { to the K-P F-stat for weak instrument. All regressions include city and state by year fixed effects. Robust standard errors, } \\
\text { clustered at the MSA level, in parenthesis. *** }<<0.01 ; * * \mathrm{p}<0.05 ; * \mathrm{p}<0.1 \text {. }\end{array}$} \\
\hline
\end{tabular}




\section{Table A5. Public Spending Per Capita, by Category}

\begin{tabular}{|c|c|c|c|c|c|}
\hline VARIABLES & $\begin{array}{c}\text { (1) } \\
\text { Education }\end{array}$ & $\begin{array}{c}(2) \\
\text { Police } \\
\end{array}$ & $\begin{array}{l}(3) \\
\text { Fire }\end{array}$ & $\begin{array}{c}\text { (4) } \\
\text { Charities and hospitals }\end{array}$ & $\begin{array}{c}(5) \\
\text { Sanitation } \\
\end{array}$ \\
\hline \multicolumn{6}{|l|}{ Panel A: OLS } \\
\hline Fr. Immigrants & $\begin{array}{c}-7.453 * * * \\
(2.332)\end{array}$ & $\begin{array}{c}0.227 \\
(0.560)\end{array}$ & $\begin{array}{l}-0.369 \\
(0.552)\end{array}$ & $\begin{array}{c}0.486 \\
(0.747)\end{array}$ & $\begin{array}{l}-0.537 \\
(0.696)\end{array}$ \\
\hline \multicolumn{6}{|l|}{ Panel B: $2 S L S$} \\
\hline Fr. Immigrants & $\begin{array}{c}-6.170 * * * \\
(2.146)\end{array}$ & $\begin{array}{l}-0.345 \\
(0.663)\end{array}$ & $\begin{array}{l}-0.213 \\
(0.680)\end{array}$ & $\begin{array}{l}-1.258 \\
(1.897)\end{array}$ & $\begin{array}{l}-1.318^{*} \\
(0.717)\end{array}$ \\
\hline F-stat & 248.6 & 288.3 & 288.3 & 220.3 & 288.3 \\
\hline Mean dep var & 4.250 & 1.338 & 1.485 & 0.635 & 1.129 \\
\hline Cities & 180 & 180 & 180 & 175 & 180 \\
\hline Observations & 534 & 540 & 540 & 516 & 540 \\
\hline
\end{tabular}

\section{Table A6. Additional Electoral Outcomes}

\begin{tabular}{|c|c|c|c|c|}
\hline VARIABLES & $\begin{array}{c}\text { (1) } \\
\text { Republicans' vote share }\end{array}$ & $\begin{array}{c}(2) \\
\text { Other parties' vote share }\end{array}$ & $\begin{array}{c}(3) \\
\text { Democrats-Republicans } \\
\text { Margin }\end{array}$ & $\begin{array}{c}\text { (4) } \\
\text { Turnout }\end{array}$ \\
\hline \multicolumn{5}{|l|}{ Panel A: OLS } \\
\hline Fr. Immigrants & $\begin{array}{c}0.337 * * \\
(0.133)\end{array}$ & $\begin{array}{c}0.191 \\
(0.127)\end{array}$ & $\begin{array}{c}-0.866 * * * \\
(0.219)\end{array}$ & $\begin{array}{c}-1.033 * * * \\
(0.233)\end{array}$ \\
\hline \multicolumn{5}{|l|}{ Panel B: 2SLS } \\
\hline Fr. Immigrants & $\begin{array}{c}0.169 \\
(0.149)\end{array}$ & $\begin{array}{c}0.235^{* * *} \\
(0.101)\end{array}$ & $\begin{array}{c}-0.573 * * \\
(0.272)\end{array}$ & $\begin{array}{c}-1.422 * * * \\
(0.183)\end{array}$ \\
\hline F-stat & 83.14 & 83.14 & 83.14 & 83.52 \\
\hline Mean dep var & 0.310 & 0.200 & 0.181 & 0.504 \\
\hline MSAs & 126 & 126 & 126 & 125 \\
\hline Observations & 378 & 378 & 378 & 375 \\
\hline \multicolumn{5}{|c|}{$\begin{array}{l}\text { Note: this Table presents results for a balanced panel of the } 126 \text { metropolitan statistical areas (MSAs) including at least one of the } 180 \text { cities with at least } 30,000 \\
\text { residents in each Census year 1910, 1920, and 1930. Panels A and B report, respectively, OLS and } 2 \text { SLS results. The dependent variable is reported at the top of each } \\
\text { column, and refers to Presidential elections. All electoral outcomes were aggregated from the county to the MSA level, using the } 1940 \text { MSAs' definitions, and were } \\
\text { computed as the average between the closest two elections after each Census year. Results are unchanged when taking the average from the two closest election years } \\
\text { (see the online appendix). Other parties' vote share refers to the vote share of all parties other than Democrats and Republicans. Fr. Immigrants is the fraction of } \\
\text { immigrants arrived in the previous decade over predicted city population, and is instrumented using the baseline version of the instrument constructed in Section } 4.2 \\
\text { (see (2) in the main text). F-stat refers to the K-P F-stat for weak instrument. All regressions include MSA and state by year fixed effects. Robust standard errors, } \\
\text { clustered at the MSA level, in parenthesis. *** p }<0.01 ; * * \text { p }<0.05 ; * \text { p }<0.1 \text {. }\end{array}$} \\
\hline
\end{tabular}




\section{Table A7. Additional Outcomes: Economic Activity}

\begin{tabular}{|c|c|c|c|c|c|c|}
\hline VARIABLES & $\begin{array}{c}\text { (1) } \\
\text { Log value added } \\
\text { per capita }\end{array}$ & $\begin{array}{c}\text { (2) } \\
\text { Log value products } \\
\text { per establishment }\end{array}$ & $\begin{array}{c}\text { (3) } \\
\text { Log value products } \\
\text { per capita }\end{array}$ & $\begin{array}{c}\text { (4) } \\
\text { Log } \\
\text { horsepower } \\
\end{array}$ & $\begin{array}{l}(5) \\
\text { TFP }\end{array}$ & $\begin{array}{c}\text { (6) } \\
\text { Log number of } \\
\text { establishments } \\
\end{array}$ \\
\hline \multicolumn{7}{|l|}{ Panel A: OLS } \\
\hline Fr. Immigrants & $\begin{array}{c}0.785 \\
(0.580)\end{array}$ & $\begin{array}{c}2.264 * * * \\
(0.704)\end{array}$ & $\begin{array}{l}0.992 * \\
(0.556)\end{array}$ & $\begin{array}{c}1.267 * * * \\
(0.475)\end{array}$ & $\begin{array}{c}0.295 \\
(0.358)\end{array}$ & $\begin{array}{l}-0.524 \\
(0.365)\end{array}$ \\
\hline \multicolumn{7}{|l|}{ Panel B: $2 S L S$} \\
\hline Fr. Immigrants & $\begin{array}{c}1.404 * * \\
(0.586)\end{array}$ & $\begin{array}{c}3.549 * * * \\
(1.214)\end{array}$ & $\begin{array}{c}2.065 * * \\
(0.845)\end{array}$ & $\begin{array}{c}1.906^{* * * *} \\
(0.705)\end{array}$ & $\begin{array}{l}1.013 * \\
(0.540)\end{array}$ & $\begin{array}{c}-1.061 * * \\
(0.439)\end{array}$ \\
\hline F-stat & 270.5 & 270.5 & 270.5 & 270.5 & 270.5 & 270.5 \\
\hline Cities & 178 & 178 & 178 & 178 & 178 & 178 \\
\hline Observations & 525 & 525 & 525 & 525 & 525 & 525 \\
\hline $\begin{array}{l}\text { Note: this table pres } \\
\text { were reported in the } \\
\text { value added per cap } \\
\text { (TFP) in Col 5; and, } \\
\text { population, and is in } \\
\text { instrument. All regr } \\
\text { p }<0.1 \text {. }\end{array}$ & $\begin{array}{l}\text { for a balanced pane } \\
\text { Manufacture betwee } \\
\text { 1; the log of value of } \\
\text { the number of estab } \\
\text { using the baseline } \\
\text { lude city and state b }\end{array}$ & $\begin{array}{l}\text { the } 178 \text { US cities with a } \\
909 \text { and } 1929 \text {. Panels A a } \\
\text { oducts per establishment } \\
\text { ments in Col } 6 \text {. Fr. Immi } \\
\text { ion of the instrument con } \\
\text { ear fixed effects. Robust }\end{array}$ & $\begin{array}{l}\text { east 30,000 residents in } \\
\text { B report, respectively, } \\
\text { er capita) in Col } 2 \text { (Co } \\
\text { ants is the fraction of i } \\
\text { ucted in Section } 4.2 \text { (se } \\
\text { andard errors, clustere }\end{array}$ & $\begin{array}{l}\text { Census yea } \\
\text { S and } 2 S L S \mathrm{r} \\
\text { the log of ho } \\
\text { igrants arrive } \\
\text { in the main } \mathrm{t} \\
\text { the MSA leve }\end{array}$ & $\begin{array}{l}\text { 1920, an } \\
\text { The deper } \\
\text { er in Col } \\
\text { previous } \\
\text { stat refer } \\
\text { renthesis. }\end{array}$ & $\begin{array}{l}\text { and for which data } \\
\text { ariable is: the log of } \\
\text { factor productivity } \\
\text { e over predicted city } \\
\text { K-P F-stat for weak } \\
<0.01 ; * * \text { p }<0.05 \text {; }\end{array}$ \\
\hline
\end{tabular}

\section{Table A8. Heterogeneous Effects and Manufacturing Wages}

\begin{tabular}{|c|c|c|c|c|c|c|c|}
\hline \multirow[b]{2}{*}{ Dep. Var: } & \multicolumn{5}{|c|}{$\underline{\text { Natives Only }}$} & \multicolumn{2}{|c|}{$\underline{\text { Natives and Immigrants }}$} \\
\hline & $\begin{array}{c}(1) \\
\text { In Labor Force }\end{array}$ & $\begin{array}{c}(2) \\
\text { High-Low Skill } \\
\text { Ratio } \\
\end{array}$ & $\begin{array}{c}(3) \\
\text { Employed } \\
\text { Illiterate } \\
\end{array}$ & $\begin{array}{c}(4) \\
\text { Employed } \\
\text { Blacks } \\
\end{array}$ & $\begin{array}{c}(5) \\
\text { Employed } \\
\text { Labor manuf } \\
\end{array}$ & $\begin{array}{c}\text { (6) } \\
\text { Log workers } \\
\text { manuf }\end{array}$ & $\begin{array}{c}\text { (7) } \\
\text { Log avg. wage } \\
\text { manuf }\end{array}$ \\
\hline \multicolumn{8}{|l|}{ Panel A: OLS } \\
\hline Fr. Immigrants & $\begin{array}{c}0.205 * * * \\
(0.050)\end{array}$ & $\begin{array}{l}-0.030 \\
(0.034)\end{array}$ & $\begin{array}{l}-0.147 \\
(0.217)\end{array}$ & $\begin{array}{l}-0.108 \\
(0.273)\end{array}$ & $\begin{array}{c}0.037 \\
(0.098)\end{array}$ & $\begin{array}{c}1.671 * * * \\
(0.557)\end{array}$ & $\begin{array}{l}-0.091 \\
(0.237)\end{array}$ \\
\hline \multicolumn{8}{|l|}{ Panel B: $2 S L S$} \\
\hline Fr. Immigrants & $\begin{array}{c}0.204 * * * \\
(0.065)\end{array}$ & $\begin{array}{l}0.061 * \\
(0.036)\end{array}$ & $\begin{array}{l}-0.109 \\
(0.332)\end{array}$ & $\begin{array}{l}-0.107 \\
(0.269)\end{array}$ & $\begin{array}{c}0.078 \\
(0.114)\end{array}$ & $\begin{array}{c}1.471 * * * \\
(0.527)\end{array}$ & $\begin{array}{l}-0.186 \\
(0.291)\end{array}$ \\
\hline F-stat & 251.3 & 251.3 & 251.3 & 251.3 & 251.3 & 270.5 & 270.5 \\
\hline $\begin{array}{l}\text { Mean dep var } \\
\text { Observations }\end{array}$ & $\begin{array}{c}0.954 \\
538\end{array}$ & $\begin{array}{c}0.978 \\
538\end{array}$ & $\begin{array}{c}0.745 \\
538\end{array}$ & $\begin{array}{c}0.750 \\
538\end{array}$ & $\begin{array}{c}0.941 \\
538\end{array}$ & $\begin{array}{c}9.063 \\
525\end{array}$ & $\begin{array}{c}6.275 \\
525\end{array}$ \\
\hline $\begin{array}{l}\text { Note: this Table pre } \\
\text { which data were re } \\
\text { were not enrolled i } \\
\text { (In Labor Force) } \\
\text { Americans, and for } \\
\text { sector (from the Ce } \\
\text { manufacturing in C } \\
\text { Katz and Margo (2 } \\
\text { baseline version of } \\
\text { and state by year fi } \\
\text { level, in parenthesis }\end{array}$ & $\begin{array}{l}\text { esents results for a ba } \\
\text { ported in the Census } \\
\text { n schools. Panels A a } \\
\text { n Col } 1 \text {; the log of } \\
\text { natives working as i } \\
\text { nsus of Manufacture } \\
\text { ol 6; and (the log of } \\
013 \text { ). Fr. Immigrant } \\
\text { the instrument constr } \\
\text { xed effects. The mea } \\
\text { s.** p }<0.01 ; * * \text { p }<0\end{array}$ & $\begin{array}{l}\text { lanced panel of the } 18 \\
\text { of Manufacture betwe } \\
\text { ind B report, respectiv } \\
\text { high skill natives ov } \\
\text { manufacturing laborer } \\
\text {, and include both im } \\
\text { the average wage in } \\
\text { s is the fraction of im } \\
\text { ucted in Section } 4.2 \text { ( } \\
\text { in of each dependent } \\
.05 ; * \text { p }<0.1 \text {. }\end{array}$ & $\begin{array}{l}\text { US cities wit } \\
1909 \text { and } 19 \\
\text {, OLS and } 2 \\
\text { the log of } 1 \\
\text { n Cols } 3 \text { to } 5 \\
\text { grant and na } \\
\text { nufacturing } \\
\text { grants arrive } \\
\text { (2) in the } m\end{array}$ & $\begin{array}{l}\text { ast 30,000 res } \\
\text { ols 6-7). Varia } \\
\text { esults. The de } \\
\text { ill natives in } \\
\text { ctively. Varia } \\
\text { orkers. The de } \\
\text { 7. To classify } \\
\text { he previous d } \\
\text { t). F-stat refe }\end{array}$ & $\begin{array}{l}\text { ts in each Cens } \\
\text { in Cols } 1 \text { to } 5 \\
\text { dent variable is } \\
2 \text {; and the em } \\
\text { in Cols 6-7 ref } \\
\text { dent variable is } \\
\text { lividuals across } \\
\text { e over predicte } \\
\text { the K-P F-stat }\end{array}$ & $\begin{array}{l}10,1920 \text {, and } 1 \\
\text { tive men in the a } \\
\text { tor for holding } \\
\text { rate for illitera } \\
\text { whole labor forc } \\
\text { f) the number o } \\
\text { gories, I use the } \\
\text { ulation, and is } \\
\text { nstrument. All r }\end{array}$ & $\begin{array}{l}\text { (Cols 1-5), and for } \\
\text { range } 15 \text { to } 65 \text { who } \\
\text { gainful occupation } \\
\text { atives, for African } \\
\text { the manufacturing } \\
\text { orkers employed in } \\
\text { sification made by } \\
\text { umented using the } \\
\text { essions include city }\end{array}$ \\
\hline
\end{tabular}


Table A9. Linguistic Distance vs Literacy

\begin{tabular}{|c|c|c|c|c|c|c|c|c|}
\hline Dep. Var. & $\begin{array}{c}\text { (1) } \\
\text { Total tax } \\
\text { revenues PC }\end{array}$ & $\begin{array}{c}\text { (2) } \\
\text { Property tax } \\
\text { revenues PC }\end{array}$ & $\begin{array}{c}(3) \\
\text { Property tax } \\
\text { rate }\end{array}$ & $\begin{array}{c}\text { (4) } \\
\text { Public } \\
\text { spending PC }\end{array}$ & $\begin{array}{c}\text { (5) } \\
\text { Education }\end{array}$ & $\begin{array}{c}(6) \\
\text { Police }\end{array}$ & $\begin{array}{c}(7) \\
\text { Charities and } \\
\text { Hospitals }\end{array}$ & $\begin{array}{c}(8) \\
\text { Sanitation }\end{array}$ \\
\hline \multicolumn{9}{|l|}{ Panel A: OLS } \\
\hline Ling. Distance & $\begin{array}{l}-0.292 \\
(0.185)\end{array}$ & $\begin{array}{l}-0.260 \\
(0.180)\end{array}$ & $\begin{array}{l}-0.997 \\
(0.701)\end{array}$ & $\begin{array}{l}-0.183 \\
(0.151)\end{array}$ & $\begin{array}{l}-0.062 \\
(0.054)\end{array}$ & $\begin{array}{l}-0.020 \\
(0.019)\end{array}$ & $\begin{array}{l}-0.044 \\
(0.036)\end{array}$ & $\begin{array}{l}-0.028 \\
(0.033)\end{array}$ \\
\hline Literacy & $\begin{array}{c}0.058 \\
(0.181)\end{array}$ & $\begin{array}{c}0.160 \\
(0.169)\end{array}$ & $\begin{array}{c}0.404 \\
(0.327)\end{array}$ & $\begin{array}{c}0.093 \\
(0.132)\end{array}$ & $\begin{array}{c}0.099 \\
(0.063)\end{array}$ & $\begin{array}{c}0.026 \\
(0.020)\end{array}$ & $\begin{array}{l}-0.060 \\
(0.041)\end{array}$ & $\begin{array}{l}-0.028 \\
(0.026)\end{array}$ \\
\hline \multicolumn{9}{|l|}{ Panel B: $2 S L S$} \\
\hline Ling. Distance & $\begin{array}{c}-0.946^{* *} \\
(0.458)\end{array}$ & $\begin{array}{c}-0.861^{*} \\
(0.450)\end{array}$ & $\begin{array}{l}-2.340 \\
(1.553)\end{array}$ & $\begin{array}{l}-0.575^{*} \\
(0.314)\end{array}$ & $\begin{array}{l}-0.177 \\
(0.128)\end{array}$ & $\begin{array}{c}0.001 \\
(0.046)\end{array}$ & $\begin{array}{l}-0.131 \\
(0.092)\end{array}$ & $\begin{array}{l}-0.065 \\
(0.054)\end{array}$ \\
\hline Literacy & $\begin{array}{l}-0.294 \\
(0.327)\end{array}$ & $\begin{array}{l}-0.217 \\
(0.303)\end{array}$ & $\begin{array}{l}-0.129 \\
(0.801)\end{array}$ & $\begin{array}{l}-0.234 \\
(0.266)\end{array}$ & $\begin{array}{c}0.096 \\
(0.099)\end{array}$ & $\begin{array}{c}0.062 \\
(0.039)\end{array}$ & $\begin{array}{l}-0.091 \\
(0.097)\end{array}$ & $\begin{array}{l}-0.054 \\
(0.051)\end{array}$ \\
\hline KP F-stat & 14.30 & 14.30 & 14.57 & 14.30 & 14.45 & 14.30 & 10.89 & 14.30 \\
\hline F-stat (Imm.) & 101.7 & 101.7 & 102.1 & 101.7 & 87.48 & 101.7 & 83.47 & 101.7 \\
\hline F-stat (Ling.) & 36.48 & 36.48 & 37.87 & 36.48 & 34.74 & 36.48 & 26.10 & 36.48 \\
\hline F-stat (Lit.) & 21.77 & 21.77 & 21.68 & 21.77 & 21.70 & 21.77 & 21.27 & 21.77 \\
\hline Mean of dep var & 12.76 & 12.10 & 19.75 & 12.16 & 4.250 & 1.338 & 0.635 & 1.129 \\
\hline Observations & 540 & 540 & 539 & 540 & 534 & 540 & 516 & 540 \\
\hline
\end{tabular}


Figure A1. Literacy Rates, for Selected Sending Regions (1910)

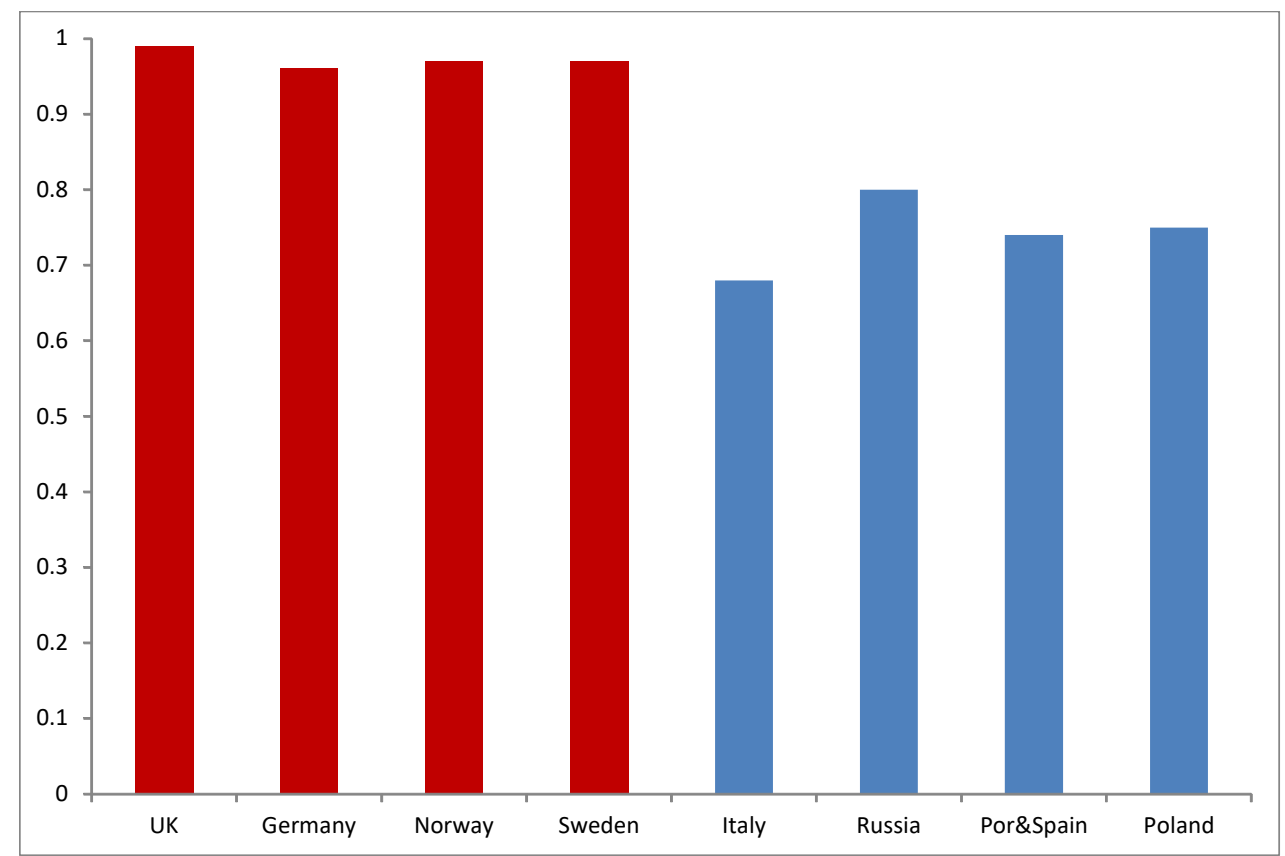

Note: this Figure reports the literacy rate for men in the age range (15-65) for selected immigrants' groups in 1910. Source: Author's calculations using IPUMS data.

Figure A2. Fraction Unskilled, for Selected Sending Regions (1910)

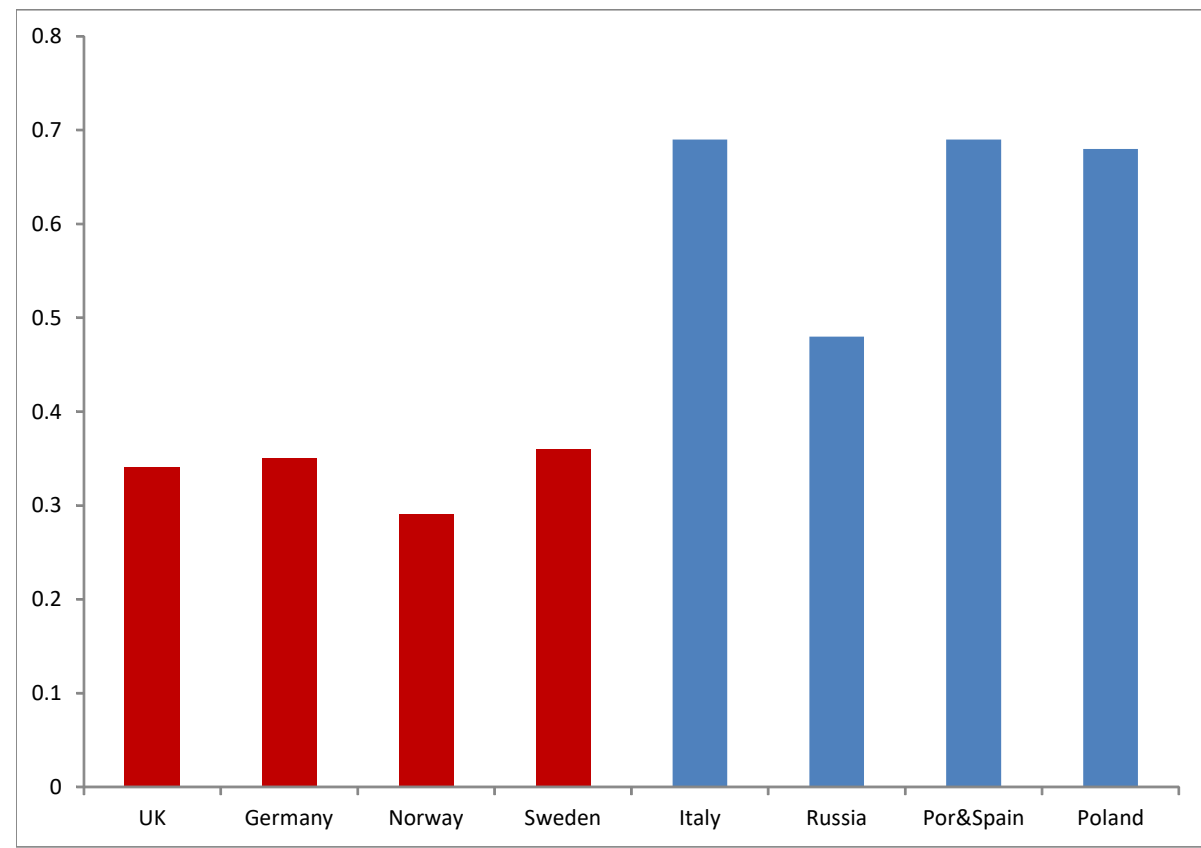

Note: this Figure reports the fraction of men in the age range (15-65) in unskilled occupations for selected immigrants groups in 1910. Source: Author's calculations using IPUMS data. 


\section{Figure A3. Immigration and Newspapers' Coverage}

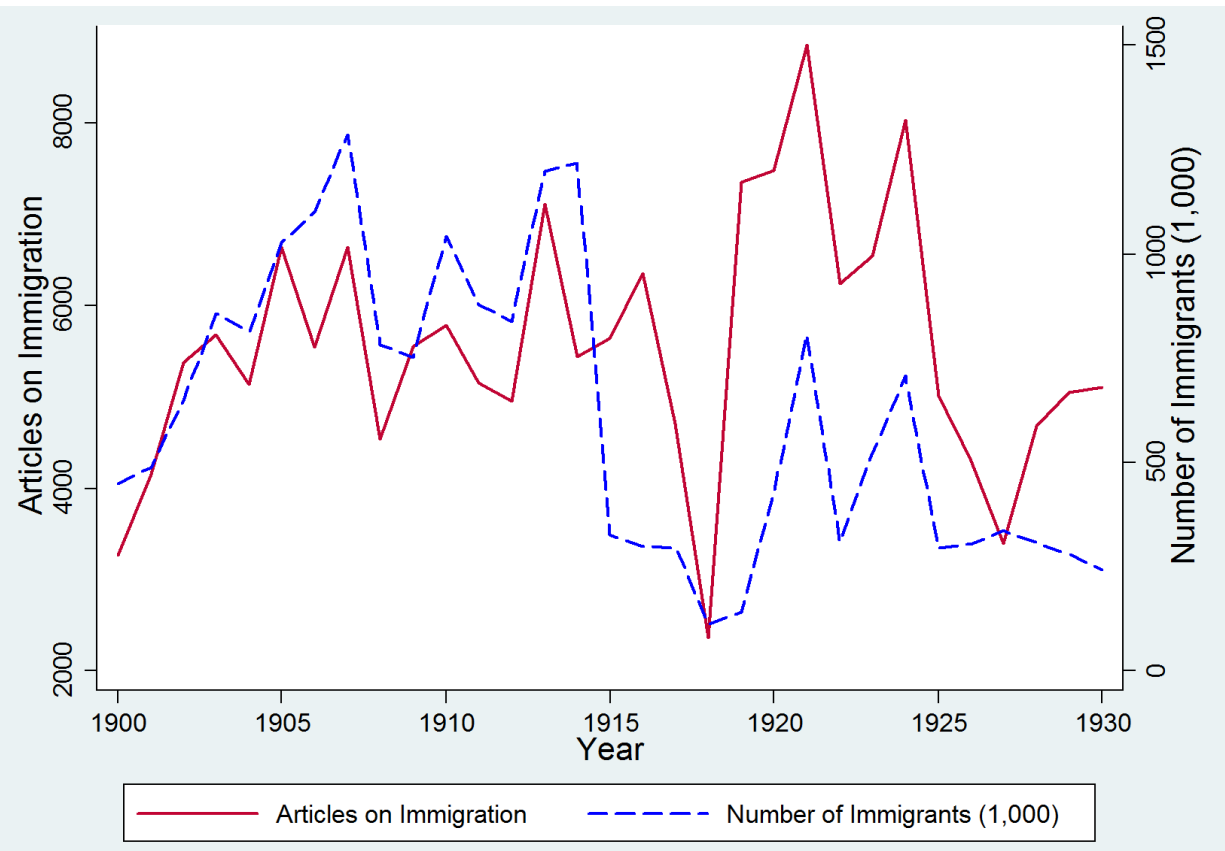

Note: the Figure plots the annual number of immigrants in thousands (dashed blue line, right-axis) and the number of times the words "immigration" and "immigrants" appeared in local newspapers for all cities with at least 30,000 residents and for which data were available in the database of Newspapersarchive (solid red line, left-axis). Source: author's calculation using data from Newspapersarchive.

Figure A4. Share of Recent Immigrants, by Region and Decade

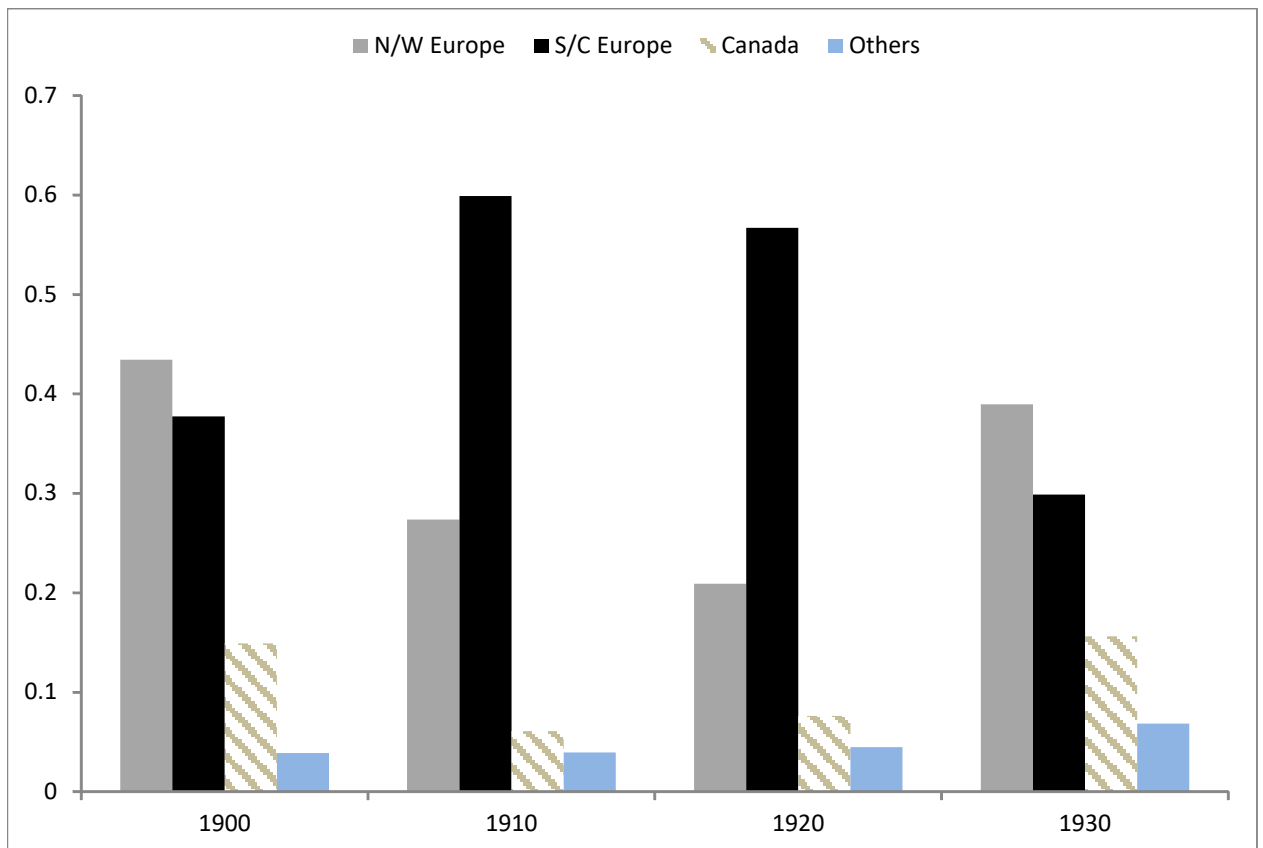

Note: Share of immigrant entering the United States in the previous ten years, by sending region and by decade. Source: Author's calculations from IPUMS sample of US Census (Ruggles et al., 2015). 
Figure A5. Recent Immigrants Over 1900 City Population, by Decade

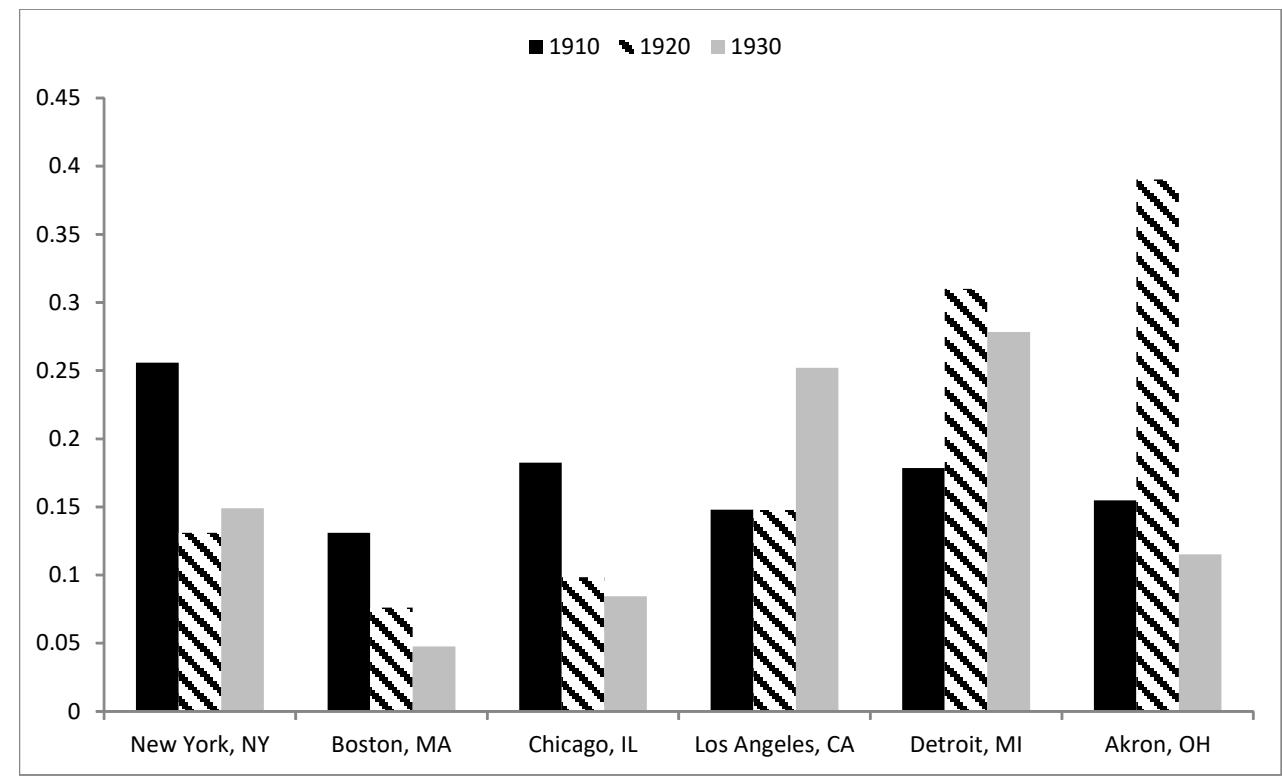

Note: Number of European immigrants that arrived in the United States in the last decade over 1900 city population, for selected cities and by decade. Source: Author's calculations from IPUMS sample of US Census (Ruggles et al., 2015).

Figure A6. Changing Composition of Immigrants in Selected Cities
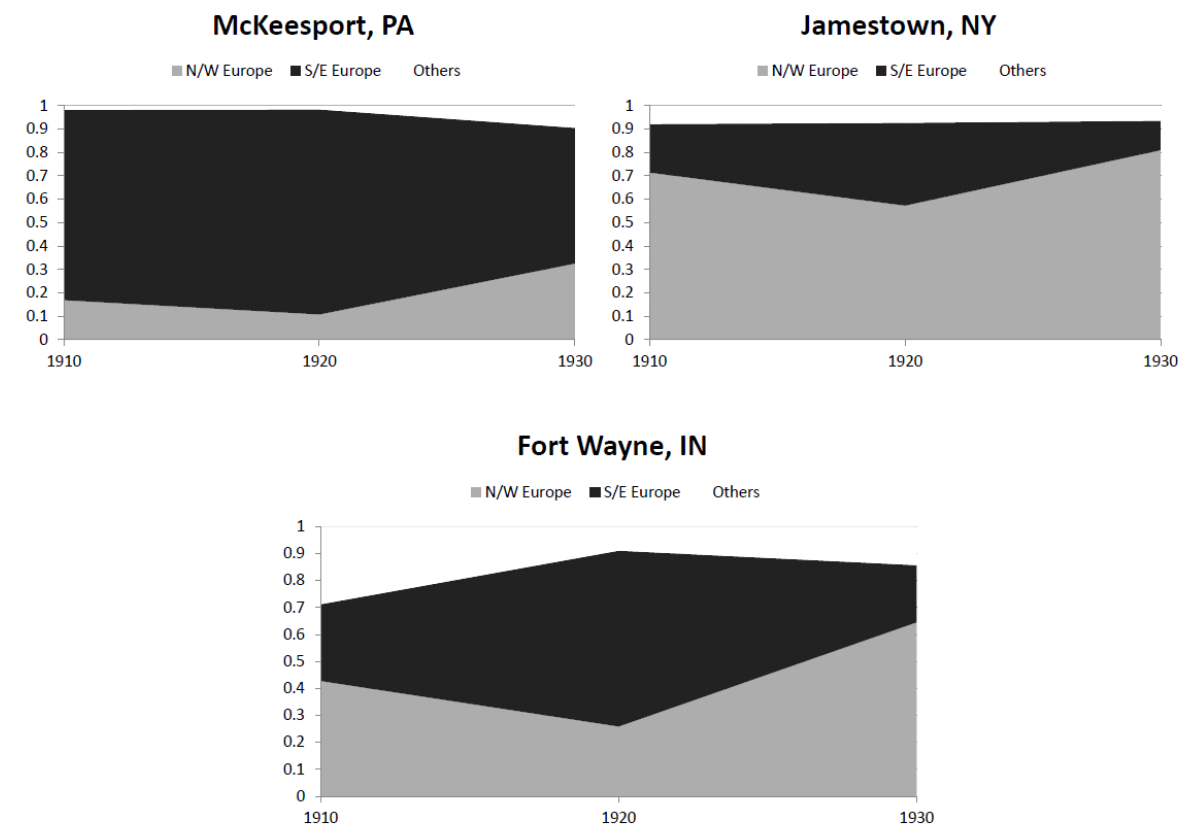

Note: Share of immigrants entering the US in the previous decade from different regions living in selected cities. Source: Author's calculations from IPUMS sample of US Census (Ruggles et al., 2015). 


\section{Figure A7. Map of Cities}

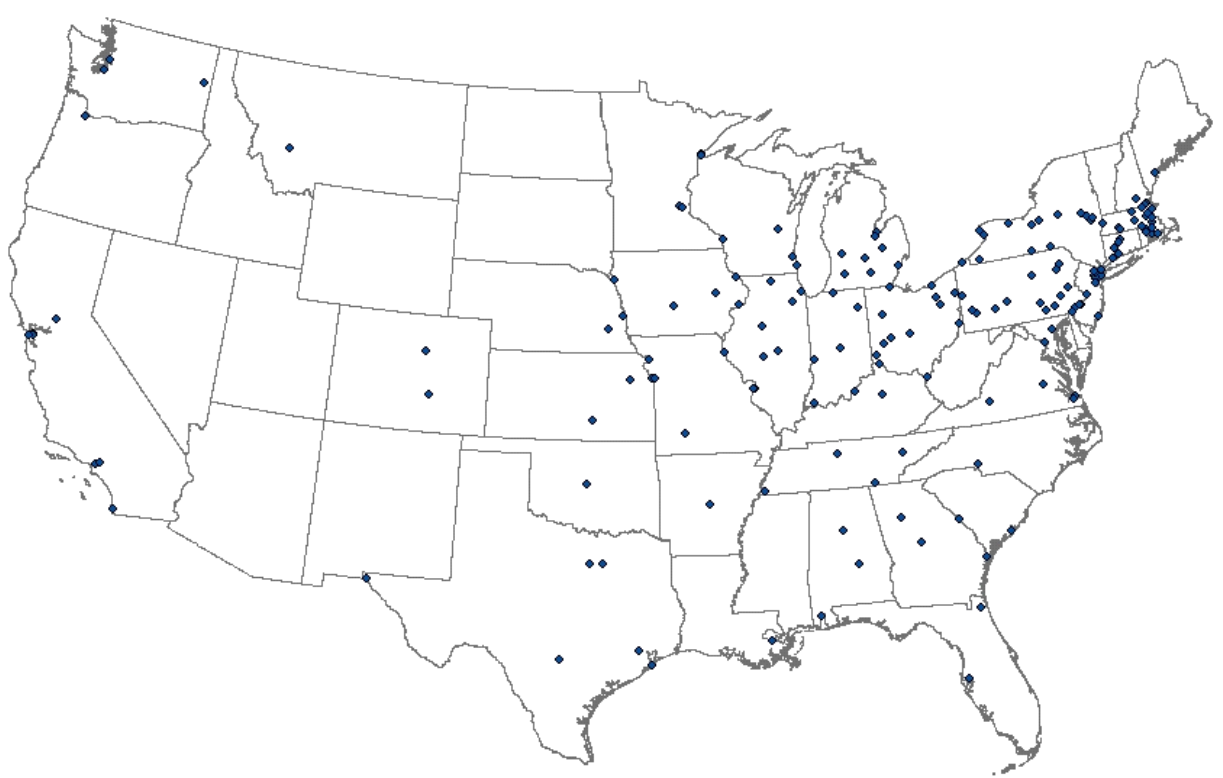

Note: The map plots the 180 cities with at least 30,000 residents in each of the three Census years 1910, 1920, and 1930

\section{Figure A8. Probability that Winner Has Given Political Orientation}

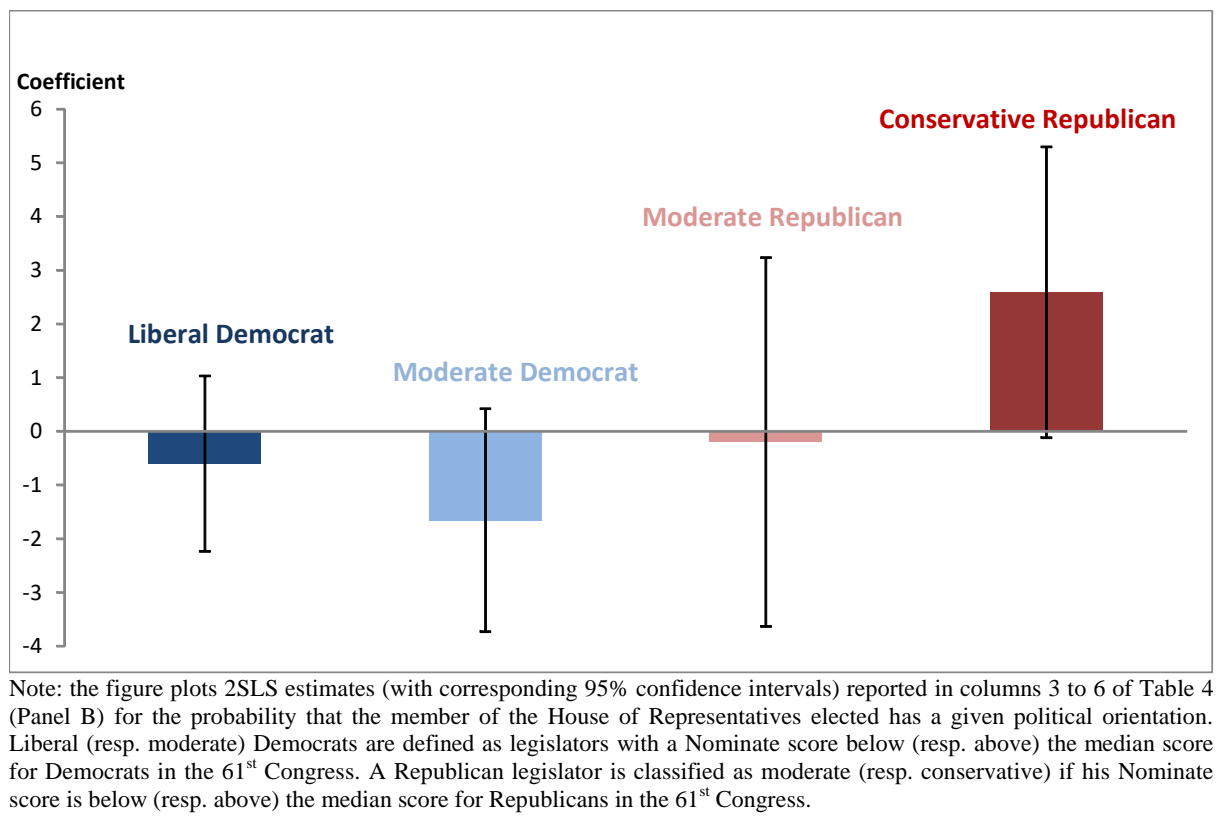




\section{Figure A9. Natives' Employment and Immigration: Reduced Form}

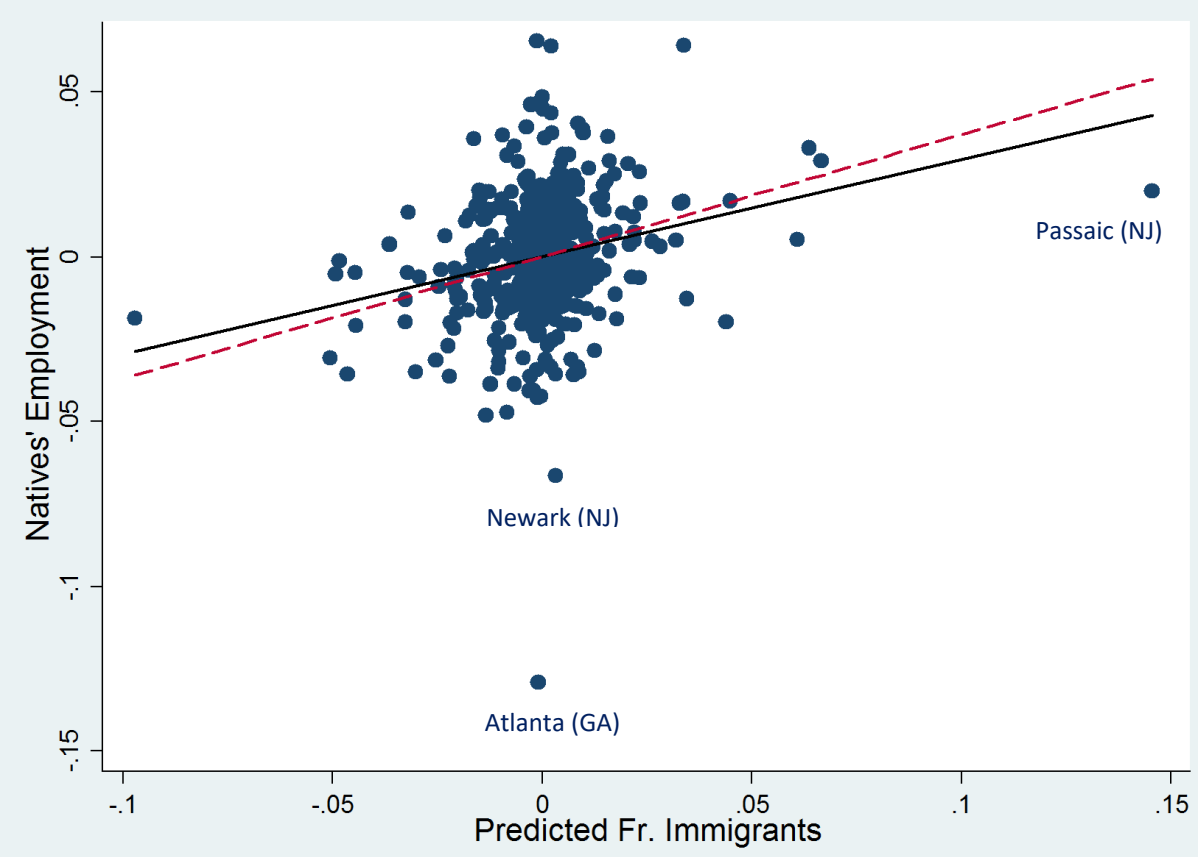

Note: the $\mathrm{y}$-axis and the $\mathrm{x}$-axis report, respectively, the employment to population ratio for native males in working age who were not in school and predicted fraction of immigrants over predicted city population in each of the three Census years, 1910, 1920, and 1930. Each point in the scatter diagram represents the residual change in each of the two variables after partialling out city and state by year fixed effects. The solid line shows the regression coefficient for the full sample (coefficient $=0.296$, standard error $=0.054$ ). The dotted (red) line shows the regression coefficient obtained when dropping the city of Passaic, NJ (coefficient=0.371, standard error=0.065). 


\section{B WWI, Quotas, and Weather Shocks Instruments}

In this section, I construct different versions of the baseline shift-share instrument of equation (2) in the paper using two alternative strategies. First, in Section B1, I replace actual immigration from each European country in each decade using only variation generated by WWI and by the Immigration Acts. Second, in Section B2, I predict country-decade immigration exploiting only weather shocks in Europe. In Section B3, I show that, as for the baseline instrument, there is a strong first stage for the instruments constructed using either of these alternative strategies.

\section{B1 World War I and Quotas Instruments}

As discussed in Section 2 in the paper, WWI and the Immigration Acts induced large and exogenous variation both in the number and in the ethnic composition of immigrants arriving in the US over time. In this section, I explicitly rely on such variation to deal with the potential concern that aggregate migration flows by country of origin, $O_{j t}^{-M}$, might be endogenous to city-specific pull factors - something that, as noted above, would invalidate the instrument constructed in equation (2) in the main text.

I start by taking (stacked) first differences of equation (1) in the paper. Next, I construct two separate instruments for the decadal change (1910 to 1920 and 1920 to 1930) in the number of immigrants received by a given city in the previous ten years. These instruments $\left(\Delta Z W_{c s}\right.$ and $\Delta Z Q_{c s}$ in equations $(B 1)$ and $\left.(B 2)\right)$ replace the actual number of immigrants entering the US from each country $j$ with a measure of predicted immigration constructed exploiting directly WWI and the Immigration Acts respectively.

Formally, the 1910-1920 and the 1920-1930 changes in immigration are instrumented with, respectively,

$$
\Delta Z W_{c s}=\frac{1}{\hat{P}_{c s, 1920}} \sum_{j} \alpha_{j c}\left(1\left[\text { Allies }_{j}\right] \cdot O_{j, 1910}-O_{j, 1910}\right)
$$

and

$$
\Delta Z Q_{c s}=\frac{1}{\hat{P}_{c s, 1930}} \sum_{j} \alpha_{j c}\left(Q_{j}-O_{j, 1920}\right)
$$

The term $O_{j, 1910}$ (resp. $O_{j, 1920}$ ) is the number of immigrants from country $j$ that entered the US between 1900 and 1910 (resp. 1910 and 1920). 1 [Allies $s_{j}$ in (B1) is a dummy equal to 1 if sending country $j$ belongs to the Allies in WWI, and zero otherwise. Finally, $Q_{j}$ in $(B 2)$ is the sum of the yearly quota for country $j$ specified by the Immigration Acts of 1921 and 1924 . 
The intuition behind equation $(B 1)$ is that, if a country was not part of the Allies, its immigration was completely shut down between 1910 and 1920. If, instead, the country belonged to the Allies, there was no change in immigration from that specific country over this period. To visually depict this intuition, Figure B1 plots the number of immigrants that entered the United States in the previous decade (relative to 1910) from Germany (dashed blue line) and the UK (red line). While WWI reduced immigration for both countries, the drop in German immigration was twice as large (relative to 1910) as that in immigration from Great Britain.

Interacting ( $B 1)$ and (B2) with year (i.e. 1920 and 1930) dummies, I re-estimate equation (1) in stacked first differences with 2SLS. In formulas, the second and the first stage equations become

$$
F D y_{c s \tau}=\xi_{s \tau}+\beta_{S} F D I m m_{c s \tau}+F D u_{c s \tau}
$$

and

$$
F D I m m_{c s \tau}=\xi_{s \tau}+\beta_{F W}\left(\Delta Z W_{c s} \cdot \tau\right)+\beta_{F Q}\left(\Delta Z Q_{c s} \cdot \tau\right)+\varepsilon_{c s \tau}
$$

where $F D$ refers to the first difference for period $\tau$, and $\xi_{s \tau}$ includes interactions between period dummies and state dummies. ${ }^{1}$ Variables $\Delta Z W_{c s}$ and $\Delta Z Q_{c s}$ in $(B 4)$ are the instruments constructed in $(B 1)$ and $(B 2)$ above, and are both interacted with a full set of year dummies $(\tau)$. While being econometrically more demanding, this strategy allows me to perform an important placebo check. Effectively, in $(B 4)$ there are four instruments, but only two of them, i.e. the interactions between $\Delta Z W_{c s}$ (resp. $\Delta Z Q_{c s}$ ) and the 1920 (resp. 1930) dummy, should be statistically significant. In Section B3 below, I explicitly test this implication, and show that, reassuringly, the WWI (resp. the quota) instrument predicts changes in immigration only when interacted with the 1920 (resp. 1930) dummy.

As a further robustness check, I also estimate a long differences specification:

$$
\Delta y_{c s}=\gamma_{s}+\beta_{L} \Delta I m m_{c s}+\Delta u_{c s}
$$

where $\Delta$ is the 1910-1930 change, $\gamma_{s}$ refers to state fixed effects, and the first stage equation is given by

$$
\Delta I m m_{c s}=\gamma_{s}+\beta_{W} \Delta Z W_{c s}+\beta_{Q} \Delta Z Q_{c s}+\Delta \varepsilon_{c s}
$$

\footnotetext{
${ }^{1}$ Note that, now, there are two time periods, 1920-1910 and 1930-1920, and all variables refer to the change during that period.
} 


\section{B2 Predicting Migration Using Weather Shocks}

A number of works have documented the link between agricultural output and weather conditions in Europe during the Age of Mass Migration. For instance, Solomou and Wu (1999) find that more than half of the variation in agricultural production in France, Germany, and the UK between 1850 and 1915 can be explained by temperature and precipitation shocks. At the same time, in a seminal contribution, Hatton and Williamson (1995) argue that agricultural conditions were strongly related to outmigration rates in Europe in this historical period. A similar pattern is found also for contemporary international migration in less developed countries (e.g. Feng et al., 2010).

Motivated by this evidence, I exploit variation in weather shocks across European countries over time to predict migration flows that are independent of US economic or political conditions. As in Sequeira et al. (2019), I make use of historical precipitation and temperature data from, respectively, Pauling et al. (2006) and Luterbacher et al. (2004). The data are measured at annual frequency for each season of the year, and are available at a 0.5 degree spatial resolution. Since out-migration is available at the country-level, I averaged weather variables over all grid cells for each country.

To estimate yearly outmigration rates, I digitized data from the Commissioner General of Immigration between 1900 and 1930. ${ }^{2}$ I use migration flows classified by race rather than by country of origin to deal with the non-trivial problem that the boundaries of several European countries changed significantly between 1900 and 1930. Ethnic groups were then mapped to the country of birth reported in the US Census of Population to match migration flows with 1900 immigrants' shares, $\alpha_{j c}$ in equation (2) in the main text. ${ }^{3}$

For each year between 1900 and 1930 and for each country, I estimated

$$
\ln \text { Outmig }_{j y}=\alpha+\sum_{s=1}^{4} \sum_{m \in M} \beta_{j s m} I_{j y-1}^{s, m}+\varepsilon_{j y-1}
$$

where $\ln \mathrm{Outmig}_{j y}$ is the $\log$ of migrants from European country $j$ in year $y$; and $I_{j y-1}^{s, m}$ is a dummy equal to 1 if the average precipitation (or temperature) in season $s$ falls in the range $m$. In my baseline specification, I consider precipitation shocks, but results are unchanged when using temperature.

Following Sequeira et al. (2019), I consider the following six categories $m \in M$ : more

\footnotetext{
${ }^{2}$ The US Census of Population records migration only at decadal frequency, and so cannot be used to perform this exercise.

${ }^{3}$ This exercise was relatively straightforward, except when matching individuals of Hebrew race to the corresponding country of origin. I experimented with several alternatives and, reassuringly, results remained always very similar.
} 
than 3 standard deviations below the mean; between 2 and 3 standard deviations below the mean; between 1 and 2 standard deviations below the mean; between 1 and 2 standard deviations above the mean; between 2 and 3 standard deviations above the mean; and more than 3 standard deviations above the mean. That is, I omit the category for precipitations (or temperatures) that are within one standard deviation below or above the mean.

After separately estimating (B7) for each country in my sample, I predict log migrant flows (for each country in each year), ln $\widehat{O u t m i} g_{j y}$, using the $\beta_{j s m}$ 's estimated from (B7). Figure B2 plots the relationship between actual and predicted (log) migration flows, and shows that the two are strongly correlated. Next, I aggregate predicted flows at the decadal frequency to get

$$
\hat{O}_{j t}=\sum_{y} \exp \left(\ln \widehat{\text { Outmi }} g_{j y}\right)
$$

Below, I assess the robustness of my results using an alternative version of the shift-share instrument, obtained by replacing $O_{j t}^{-M}$ with $\hat{O}_{j t}$ in equation (2) in the main text.

\section{B3 First Stage Regressions}

Table B1 reports results for the stacked first differences and for the long differences specifications, i.e. equations $(B 4)$ and $(B 6)$ respectively, in columns 7 and 8. To ease comparisons, columns 1 to 6 replicate Table 2 in the main text. At the bottom of the table, columns 7 and 8 also present the p-value for the test of overidentifying restrictions. Reassuringly, in both cases, not only the F-stat is well above conventional levels, but also, the null hypothesis of overidentifying restrictions cannot be rejected. Furthermore, in column 7 , the interaction between year dummies and the WWI instrument is significant only for 1920, while that between year dummies and the quota instrument is significant only for 1930. Conversely, when interacting the WWI and the quota instruments with, respectively, the 1930 and the 1920 dummies, coefficients are never statistically significant and, especially for WWI, an order of magnitude smaller. ${ }^{4}$

Next, in Table B2, I report estimates for the relationship between actual immigration and the instrument constructed in Section B2. To ease comparisons, columns 1 and 2 show the baseline specification estimated in the main text, and reported in columns 2 and 3 of Table 2. Next, columns 3 and 4 replace actual migration flows from each sending country with those predicted using only weather shocks at origin (see (B8)). Column 3 scales the

\footnotetext{
${ }^{4}$ While only the interaction between the 1930 dummy and the quota instrument is statistically significant, the coefficient is not statistically different from that on the interaction between the quota istrument and the 1920 dummy. One possible explanation is that the literacy test introduced in 1917 was more binding for immigrants from Southern and Eastern Europe - groups also more penalized during the 1920s because of the Immigration Acts (see Section 2).
} 
number of immigrants by predicted population, while column 4 divides it by 1900 population. Both the coefficients and the F-stat in columns 3 and 4 fall, but the relationship between actual and predicted immigration remains positive and highly significant even when using this alternative instrument. 


\section{Table B1. First Stage for WWI and Quota Instruments}

\begin{tabular}{|c|c|c|c|c|c|c|c|c|}
\hline & \multicolumn{8}{|c|}{ Dep. Variable: Fraction of Immigrants } \\
\hline & $(1)$ & $(2)$ & (3) & (4) & $(5)$ & (6) & (7) & $(8)$ \\
\hline $\mathrm{Z}$ & $\begin{array}{c}0.840 * * * \\
(0.056)\end{array}$ & $\begin{array}{c}0.968 * * * \\
(0.064)\end{array}$ & $\begin{array}{c}0.999 * * * \\
(0.059)\end{array}$ & $\begin{array}{c}0.948^{* * * *} \\
(0.104)\end{array}$ & $\begin{array}{c}0.893 * * * \\
(0.091)\end{array}$ & $\begin{array}{c}0.900 * * * \\
(0.081)\end{array}$ & & \\
\hline ZW*1920 & & & & & & & $\begin{array}{c}0.774 * * * \\
(0.106)\end{array}$ & $\begin{array}{c}0.838 * * * \\
(0.067)\end{array}$ \\
\hline ZQ*1930 & & & & & & & $\begin{array}{c}0.771 * * \\
(0.349)\end{array}$ & $\begin{array}{c}1.236^{* * * *} \\
(0.188)\end{array}$ \\
\hline ZW*1930 & & & & & & & $\begin{array}{c}0.064 \\
(0.082)\end{array}$ & \\
\hline ZQ*1920 & & & & & & & $\begin{array}{c}0.464 \\
(0.423)\end{array}$ & \\
\hline 1900 population & & $\mathrm{X}$ & & & & & & \\
\hline Predicted population & & & $\mathrm{X}$ & & & & & \\
\hline MSA analysis & & & & $\mathrm{X}$ & & & & \\
\hline Year by 1900 Log & & & & & $\begin{array}{l}\text { City and } \\
\text { imm pop }\end{array}$ & $\begin{array}{c}\text { Value added } \\
\text { manuf. }\end{array}$ & & \\
\hline WWI-Quotas IV & & & & & & & First Diff. & Long Diff. \\
\hline F-stat & 225.1 & 226.7 & 288.3 & 82.65 & 96.48 & 124.8 & 106.8 & 207.4 \\
\hline P-value Overid. Test & & & & & & & 0.456 & 0.432 \\
\hline Cities & 180 & 180 & 180 & 127 & 180 & 176 & 180 & 180 \\
\hline Observations & 540 & 180 & 540 & 379 & 540 & 528 & 360 & 180 \\
\hline $\begin{array}{l}\text { Note: the sample includes a } \\
\text { scaled by actual population, } \\
\text { predicted number of immigr } \\
\text { actual number of immigrant } \\
\text { between year dummies and, } \\
\text { stacked first differences equ } \\
\text { (equations (B1) and (B2) in } \\
\text { regressions partial out city ar }\end{array}$ & $\begin{array}{l}\text { anced panel of tl } \\
\text { d the instrumen } \\
\text { s by, respectivel } \\
\text { e scaled by prec } \\
\text { pectively, the (lo } \\
\text { n (B4) and long } \\
\text { line appendix } \mathrm{E} \\
\text { tate by year fixe }\end{array}$ & $\begin{array}{l}80 \text { US cities w } \\
\text { the leave-out } \\
900 \text { and predic } \\
\text { d population. } \\
\text { f) } 1900 \text { city an } \\
\text { ferences equati } \\
\text { F-stat refers t } \\
\text { fects. Robust st }\end{array}$ & $\begin{array}{l}\text { It least } 30,000 \\
\text { ion of the shift } \\
\text { population. Fro } \\
4 \text { replicates the } \\
\text { migrants popul } \\
\text { B6) replacing } \\
\text { e K-P F-stat f } \\
\text { ard errors, clus }\end{array}$ & $\begin{array}{l}\text { ents in each Ce } \\
\text { re IV in equati } \\
\text { ol } 3 \text { onwards, } \\
\text { lysis aggregatin } \\
\text {, and the (log o } \\
\text { andard shift-sh } \\
\text { eak instrument. } \\
\text { at the MSA les }\end{array}$ & $\begin{array}{l}\text { year } 1910,192 \\
\text { (Section } 4.2) \\
2 \text { presents res } \\
\text { unit of analys } \\
04 \text { value addec } \\
\text { nstrument with } \\
\text { s } 7-8 \text { report th } \\
\text { n parenthesis. * }\end{array}$ & 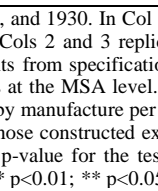 & $\begin{array}{l}\text { the actual numb } \\
\text { ate Col } 1 \text { by sca } \\
\text { ns where both th } \\
\text { Cols } 5 \text { and } 6 \text { inc } \\
\text { establishment. C } \\
\text { loiting World } \mathrm{W} \\
\text { of overidentifyi } \\
; * \text { p }<0.1 \text {. }\end{array}$ & $\begin{array}{l}\text { of immigrants i } \\
\text { ig the actual an } \\
\text { predicted and th } \\
\text { de the interactior } \\
7 \text { and } 8 \text { estimat } \\
\text { I and the quota } \\
\text { restrictions. Al }\end{array}$ \\
\hline
\end{tabular}

\section{Table B2. First Stage for Weather Shocks Instrument}

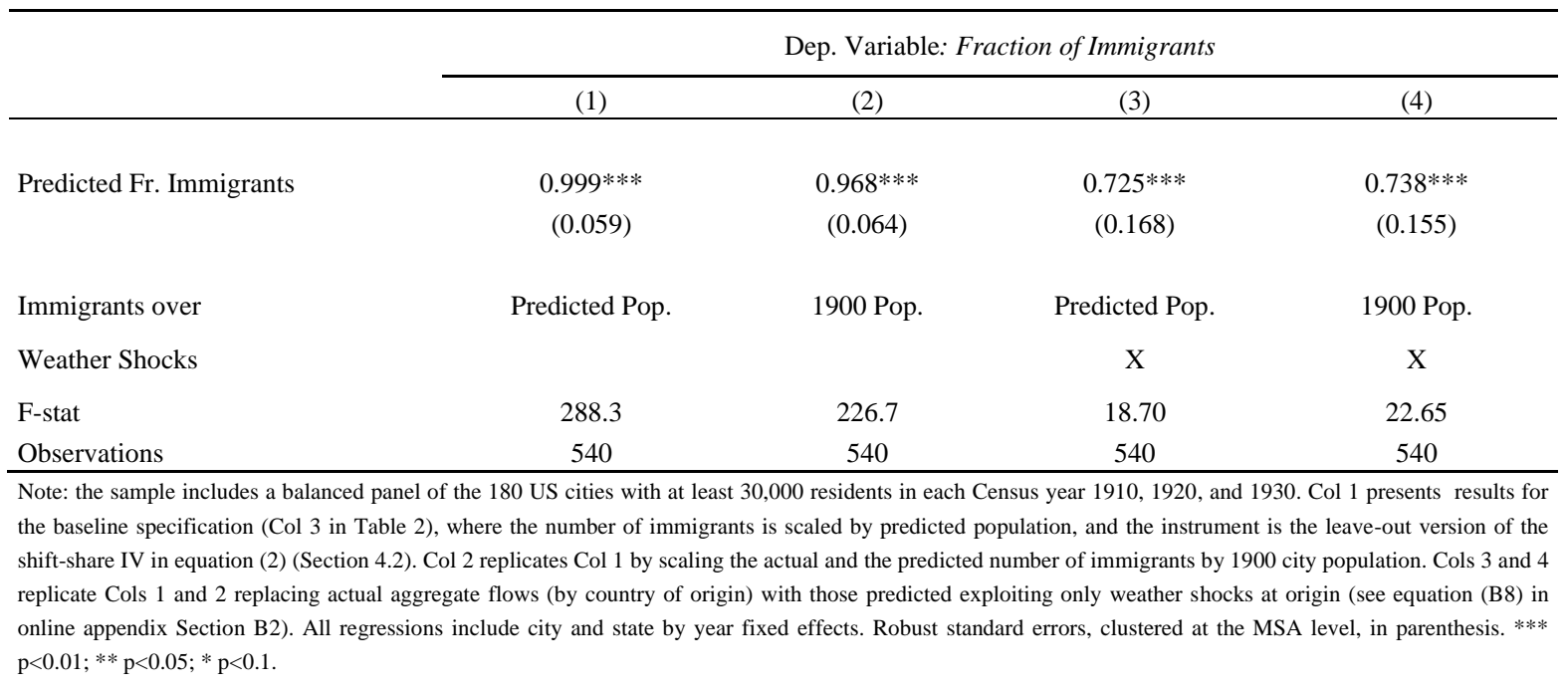


Figure B1. The Effect of WWI on Immigration from Allies and Enemies

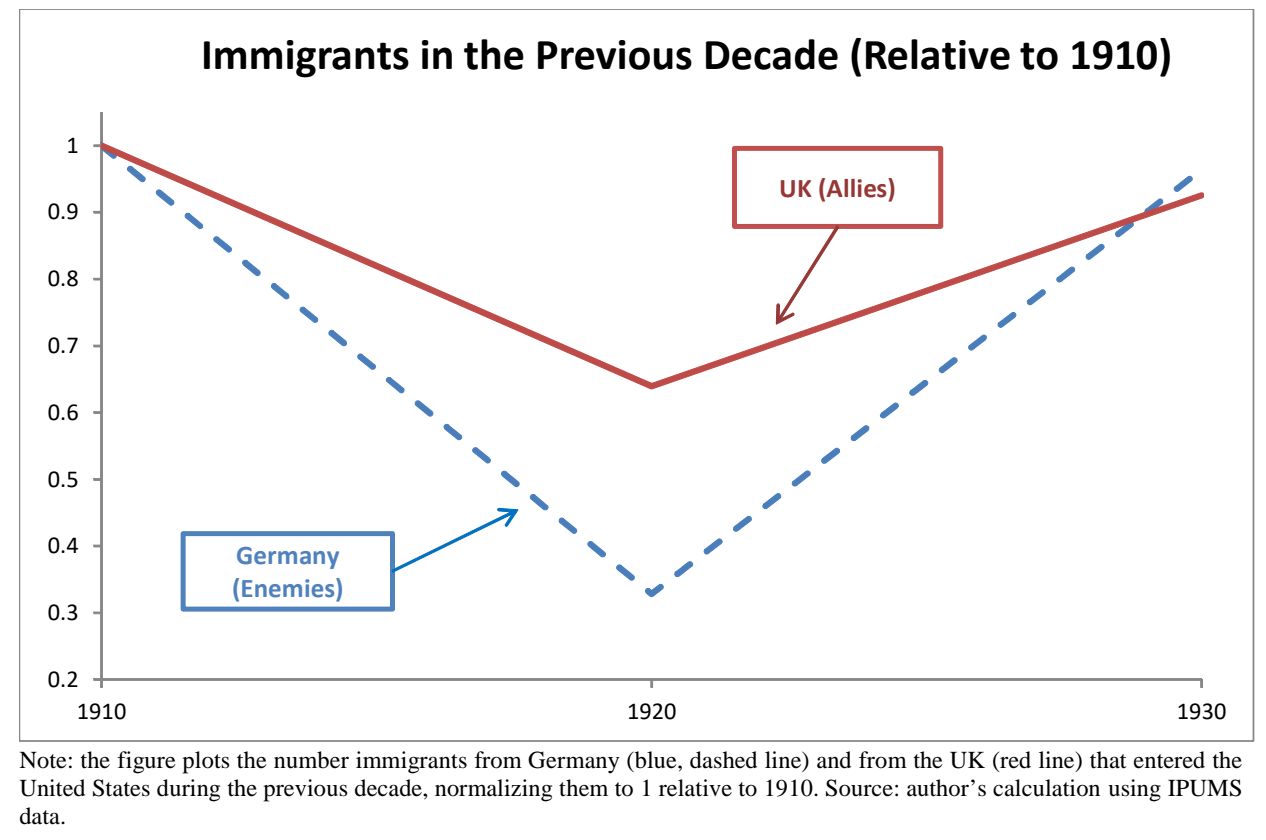

Figure B2. Actual Versus Predicted Migration Using Precipitation Shocks

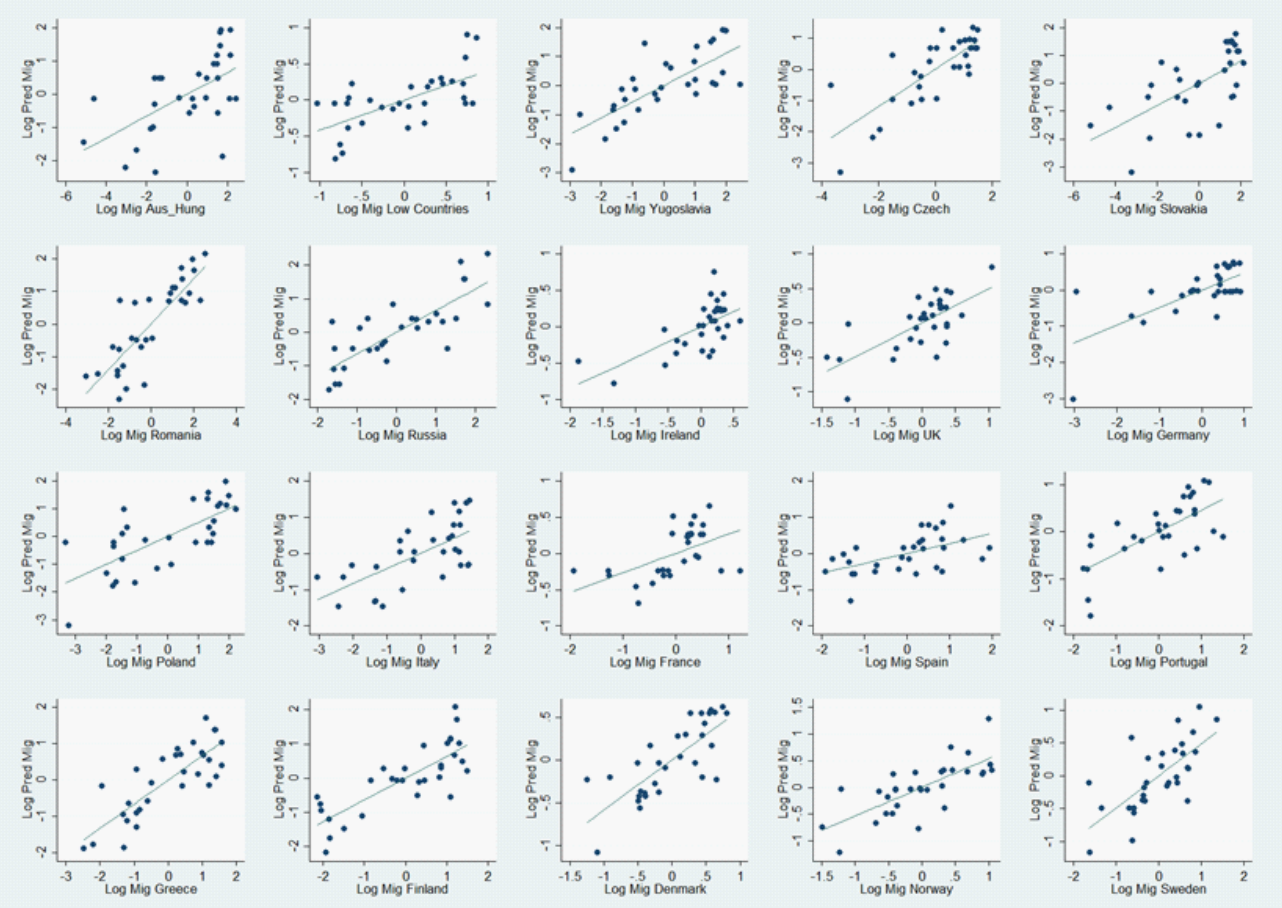




\section{Graphical Example and Immigrants' Settlements}

\section{C1 Graphical Example}

The instrument constructed in equation (2) in the main text exploits two sources of variation: first, cross-sectional variation in the share of individuals from each ethnic group living in different US cities in $1900\left(\alpha_{j c}\right)$; second, time-series variation induced by changes in the total number of immigrants from any sending region entering the United States in a given

decade $\left(O_{j t}^{-M}\right)$. Figure $\mathrm{C} 1$ presents an example for three cities (Chicago, Milwaukee, and San Francisco) and two ethnic groups (Italians and Germans) to illustrate the variation underlying the instrument.

Between 1910 and 1930, Italian immigration fell monotonically, while German immigration declined between 1910 and 1920 due to WWI, but rebounded after 1920, as the quotas were quite generous with respect to Germany. Chicago (Panel A) had large Italian and German communities in 1900. In line with the aggregate flows, both the actual (straight lines) and the predicted (dotted lines) number of Italians (yellow lines) and Germans (blue lines) arriving in Chicago fell between 1910 and 1920. However, after 1920, while Italian immigration continued its decline, Chicago experienced a positive immigration shock from Germany.

Milwaukee, instead, had a relatively large German community, but almost no Italians in 1900. Thus, as shown in Panel B, variation in immigration for this city resulted from changes in German, and not Italian, immigration. Finally, while very few Germans were living in San Francisco in 1900, Italian settlements were fairly large in this city. As documented in Panel $\mathrm{C}$, the actual and predicted immigration shock for San Francisco was due to the decline in Italian immigration, and only marginally to the inflow of Germans after 1920.

The instrument in equation (2) in the main text extends this example to many cities and many ethnic groups, but the logic behind it can be grasped by looking at the patterns in Panels A to C of Figure C1.

\section{C2 Immigrants' Settlements}

The cross-sectional variation underlying the instrument in equation (2) in the main text is based on the idea that immigrants cluster geographically and their settlements are highly persistent due to social networks and family ties, and not because of local pull factors (Card, 2001; Stuart and Taylor, 2016). As documented in Sequeira et al. (2019), the gradual expansion of the railroad network during the second half of the nineteenth century is a strong predictor of the geographic distribution of immigrants in the US: places that gained access 
to the railroad just before an immigration boom received more immigrants in the following decade. Since the timing of outmigration varied widely across European countries, depending on local political and economic conditions (Hatton and Williamson, 1998), different US regions were populated by different ethnic groups before 1900. Early settlers then acted as a catalyst for subsequent migrants from the same ethnic group (Lafortune and Tessada, 2014).

The geographic concentration of Europeans in the United States during the Age of Mass Migration is discussed, among others, by Abramitzky and Boustan (2017). For instance, Italians clustered in the north-eastern states of New York, Pennsylvania, and New Jersey, and in California, whereas Germans and Scandinavians settled mainly in the lower and in the upper Midwest respectively. Figure C2 visually confirms these patterns in my data by plotting the share of individuals from different European regions living in selected US cities in 1900. Figure C3 presents a similar example for Ohio, and shows that differences in immigrants' settlements existed also within the same state. This is important, for otherwise the instrument in (2) would not have power, since my empirical strategy exploits only within state variation in immigration. 


\section{Figure C1. A Simple Example: Actual and Predicted Immigration}
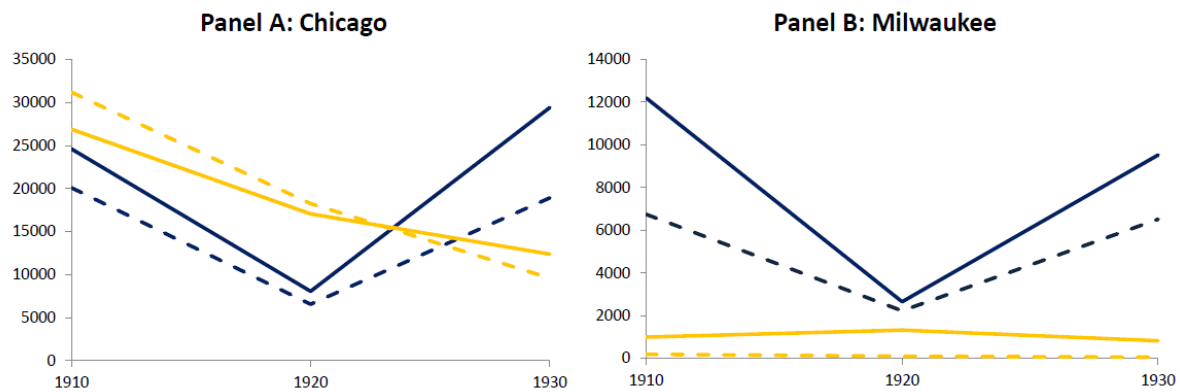

Panel C: San Francisco

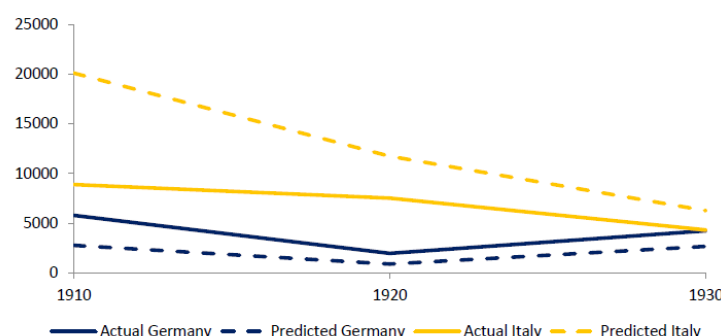

Note: This Figure reports the actual and predicted number of Italians and Germans arrived during the previous decade to Chicago (Panel A), Milwaukee (Panel B), and San Francisco (Panel C), in 1910, 1920, and 1930. Predicted immigration is obtained from the instrument constructed in equation (2) in the main text. Source: from IPUMS sample of US Census (Ruggles et al., 2015). 
Figure C2. Share of European Immigrants in US Cities, 1900

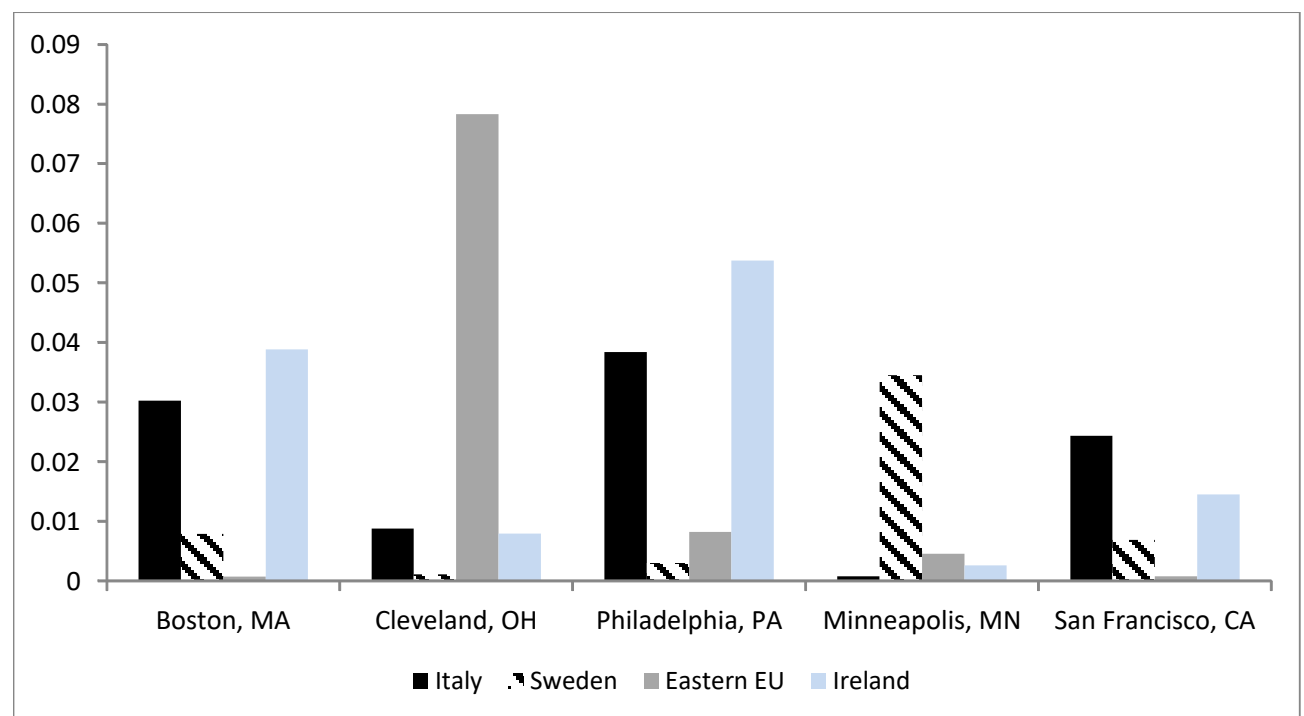

Note: share of individuals of European ancestry living in US cities in 1900, for selected ethnic groups. Source: Author's calculations using IPUMS data.

Figure C3. Share of European Immigrants in Ohio, 1900

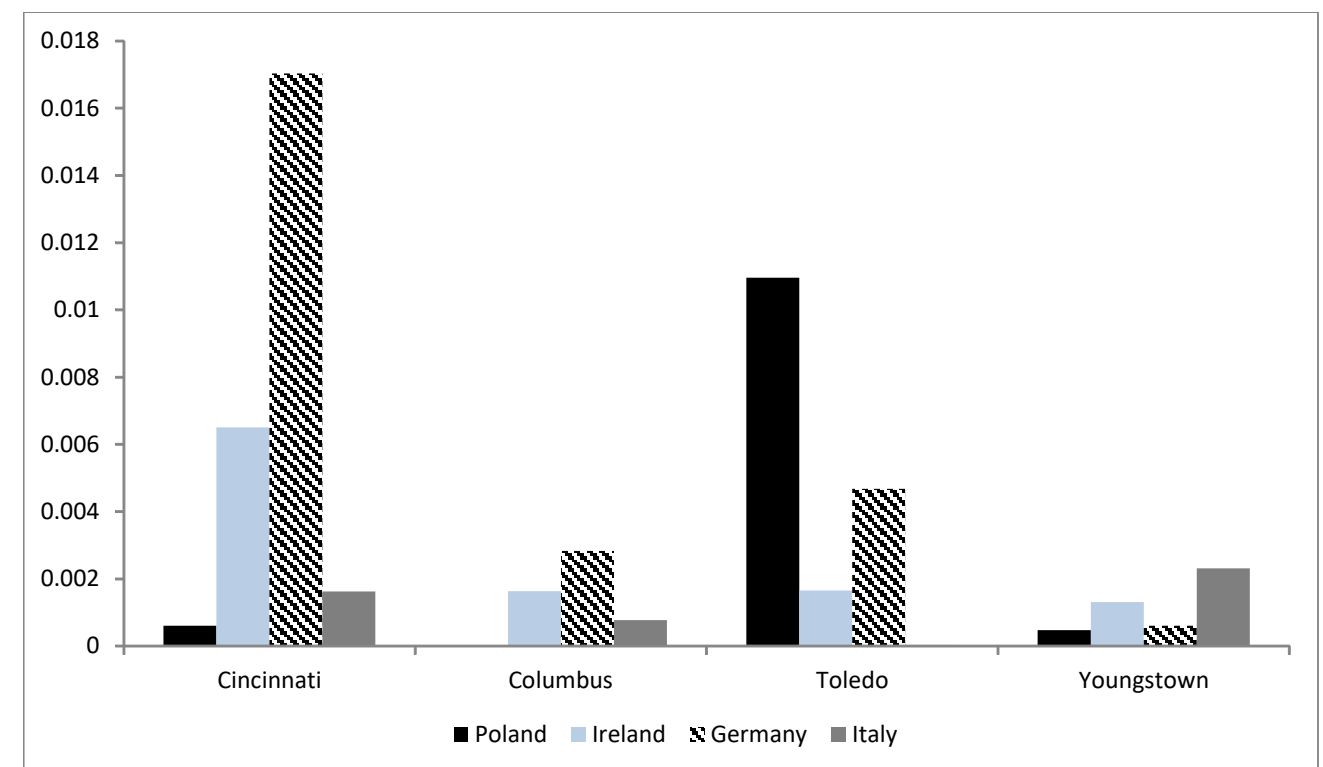

Note: share of individuals of European ancestry living in selected cities of Ohio in 1900, for selected ethnic groups. Source: Author's calculations using IPUMS data. 


\section{Robustness Checks}

In this section, I conduct a number of robustness checks. Section D1: $i$ ) tests for pre-trends; ii) augments the baseline specification with a predicted measure of industrialization and interacts year dummies with many 1900 city characteristics; iii) tests the stability of results when including interactions between year dummies and the 1900 share of immigrants from each sending country. Section D2 shows that results are robust to: $i$ ) aggregating the unit of analysis to the MSA level; and $i i$ ) allowing for the presence of spillovers from other cities in the same state. Section D3 replicates the analysis using the WWI and quota, and the weather shocks instruments constructed in online appendix B.

Section D4 documents that the shift-share instrument in this setting is unlikely to conflate the short and the long run effects of immigration (Jaeger et al., 2018). Section D5 shows that results are robust to: $i$ ) dropping potential outliers; $i i)$ scaling the number of immigrants in different ways; and $\mathrm{iii}$ ) using alternative definitions of immigration. Section D6 explores possible non-linearities, and compares the effects of relative vs absolute size of immigration. Section D7 documents that results are robust to different assumptions on bias due to selection on observables and unobservables using the procedure described in Oster (2017). Section D8 replicates the analysis on legislators' ideology using cross-sectional regressions, and shows that results on Presidential elections are robust to constructing outcomes in different ways.

\section{D1 Pre-Trends and Interactions}

The validity of the shift-share instrument constructed in equation (2) in the main text rests on one key assumption: cities receiving more immigrants (from each sending area) before 1900 must not be on different trajectories for the evolution of economic and political conditions in subsequent decades (see also Borusyak et al., 2018, and Goldsmith-Pinkham et al., 2018). In this section, I test this assumption in a variety of ways. First, in Table D1, I test for pre-trends, regressing the pre-period change in the outcomes of interest against the 1910 to 1930 change in immigration predicted by the instrument. ${ }^{5}$ Reassuringly, coefficients (reported in Panel B) are never statistically significant. Also, and importantly, they are quantitatively different from the baseline 2SLS estimates, reported in Panel A. These results indicate that, before 1900, European immigrants did not settle in cities that were already undergoing economic growth or political change.

Next, in Panel B of Table D2, I check that results are unchanged when separately con-

\footnotetext{
${ }^{5}$ For public spending per capita and property tax rates, I use 1906 as pre-period year, since this was the first year for which the data were available. For the same reason, for the log of value added per establishment and for log of establishment size, I use 1904 as pre-1910 year. For other outcomes, I instead use 1900.
} 
trolling for a measure of predicted industrialization constructed by interacting 1900 industry shares with national growth rates as in Sequeira et al. (2019). ${ }^{6}$ The rest of Table D2 includes interactions between year dummies and i) 1900 city and immigrant population (Panel C); ii) 1904 value added per establishment (Panel D). In most cases, results are unchanged. The only notable exception emerges for the Democrats' vote share in Presidential elections, when year dummies are interacted with the 1900 immigrant and city population (column 3, Panel C). Reassuringly, however, this pattern does not appear for any other outcome. Moreover, results for all outcomes remain similar to the baseline estimates when, in Table D3 (Panels A to D), I also include interactions between year dummies and: i) 1900 ratio of high to low skilled natives; ii) 1900 fraction of blacks; iii) 1904 value of products per establishment; iv) 1900 employment share in manufacturing. ${ }^{7}$

When interacting year dummies with the 1904 value added by manufacture (Table D2, Panel D), value of products (Table D3, Panel C), and employment share in manufacturing (Table D3, Panel D), the coefficient for public spending per capita (column 1) becomes almost twice as large (in absolute value) as that from the baseline specification. Yet, as documented in Table D4, this is due to the slightly different sample of cities for which 1904 Census of Manufacture data are available. ${ }^{8}$ Specifically, in Table D4, I estimate the baseline specification for the full sample (Panel A) and for the sample of cities for which data were reported in the 1904 Census of Manufacture (Panel B). The coefficient on public spending per capita (column 1) in Panel B is twice as large as that for the full sample. Also, and importantly, this coefficient is quantitatively very close to that reported in Panel D of Table D2 and in Panels C and D of Table D3 (column 1).

Finally, I replicate the analysis by interacting the 1900 share of each immigrant group $\left(\alpha_{j c}\right.$ in equation (2) in the main text) with year dummies. ${ }^{9}$ This is an important test to check whether results are driven by some specific group that happened to settle in specific cities before 1900, and at the same time is responsible for a large component of the variation in immigration over time (Goldsmith-Pinkham et al., 2018). Figures D1 and D2 plot the 2SLS coefficient (with corresponding 95\% confidence intervals) for the effect of immigration on each of the four main political and economic outcomes in specifications where I control for interactions between year dummies and $\alpha_{j c}$ in equation (2). To ease comparison with results reported in the main text, the first dot on the left of each panel plots the baseline

\footnotetext{
${ }^{6}$ Formally, predicted industrialization, $i n d_{c s t}$, is constructed as $i n d_{c s t}=\sum_{i} \gamma_{c i}^{900} g_{i t}$, where $\gamma_{c i}^{900}$ is the (one digit) industry share of industry $i$ in city $c$ in 1900, and $g_{i t}$ is the national growth rate of that industry between $t$ and $t-10$.

${ }^{7}$ Results, shown in Table D15 below, are also robust when including all interactions simultaneously.

${ }^{8}$ Cities for which 1904 industrial data are missing are: Pasadena (CA), Perth Amboy (NJ), Superior (WI), and Washington DC.

${ }^{9}$ See Table A1 for the list of countries.
} 
point estimate (see Tables 3 and 5 in the main text).

Results are very stable and, in most cases, coefficients always remain statistically significant and quantitatively close to the baseline effect obtained without including any interaction.

\section{D2 Spillovers}

The shift-share instrument - but more generally any cross-area design study - assumes no geographic spillovers across treated units (i.e., in this case, cities receiving immigrants). Given the proximity of some cities in my sample, especially in northeastern states like New York or Massachusetts, this might be an excessively stringent assumption. Moreover, as discussed in Borjas (2003), immigration may induce some native workers to leave the local labor market, moving to less exposed areas. In turn, this mechanism might dilute the (negative) effect of immigration on natives' wages.

To address these and similar concerns, I replicate the analysis aggregating the unit of analysis to the MSA level, a reasonable proxy for integrated (local) labor markets at the time. Results, reported in Panel B of Table D5, remain quantitatively very similar to those presented in Table 5 (also reported in Panel A of Table D5), even though the coefficient for $\log$ occupational scores (column 2) is no longer statistically significant. ${ }^{10}$ These findings are consistent with historical accounts suggesting that, differently from the Great Migration of blacks from the South to the North of the United States (Boustan, 2010), natives did not systematically leave cities in response to European immigration. In line with this idea, in online appendix E2, I show that, if anything, immigration promoted internal in-migration (Table E6).

Next, to more directly tackle the issue of spillovers at the state level, I separately include the average fraction of immigrants received by other cities in the same state (Table D5, Panel C). The average fraction of immigrants received by other cities is instrumented with the equivalent version of the instrument in equation (2) in the main text. To ease the interpretation of coefficients, both the fraction of immigrants in the city and the average fraction of immigrants in other cities are standardized by subtracting the mean and dividing through the standard deviation. While the coefficient on immigration to other cities is negative for all outcomes, except for occupational scores (column 2), it is smaller in magnitude than the (positive) direct effect of immigration and not statistically significant at conventional levels. ${ }^{11}$ This suggests that immigration to other cities in the state likely had a small, if

\footnotetext{
${ }^{10}$ The lower precision of these estimates should not be surprising, given that when aggregating observations up to the MSA level the number of units moves from 180 to 127.

${ }^{11}$ In unreported results, I also replicated the analysis for political outcomes presented in Table 3. Im-
} 
not negligible, effect on economic conditions within individual cities. Findings in Panel $\mathrm{C}$ of Table D5 are consistent with those in Sequeira et al. (2019) who document that immigration had a positive effect on industrialization in US counties between 1860 and 1920, and did not generate negative spillovers.

\section{D3 Push Factors Instruments}

As discussed in Section 4.2 in the paper, one potential concern with the shift-share instrument is that local economic shocks in US cities pulled immigrants from specific countries. For example, an economic boom in New York City may have attracted Italian immigrants to the US. Given the size of the local labor market in New York, upon arrival, all Italians might have settled precisely in this city to take advantage of the economic opportunities. ${ }^{12}$ Under this scenario, and if this were true also for other cities and other national groups, the identifying assumption would be violated, and the instrument would be spuriously correlated with changes in economic conditions across cities.

I address this issue in two different ways. First, I replicate results using the instrument constructed in online appendix B1, where national inflows from each European origin $\left(O_{j t}^{-M}\right)$ are predicted using WWI and the quotas. Second, I use the version of the instrument constructed relying on weather shocks across European countries to predict national immigration flows (online appendix B2). Table D6 (Panels B and C) replicates results using the stacked first difference and the long difference version of the WWI and quota instrument (equations $(B 1)$ and $(B 2)$ in online appendix B1), and shows that my estimates are robust to these specifications. As for the interaction between year dummies and 1900 immigrant population (Table D2, Panel C), only for the Democrats' vote share in Presidential elections, in the stacked first difference specification, the coefficient is significantly affected. In all other cases, instead, results are unchanged.

In Panel B of Table D7, I perform an even more stringent robustness check by augmenting the stacked first difference specification (equation (B3) in online appendix B1) with the interaction between year dummies and (the log of) 1900 city and immigrants population. This amounts to comparing cities that in 1900 had the same fraction of immigrants, and that experienced changes in immigration only because of variation in sending countries induced by World War I and by the Immigration Acts. Not surprisingly, the precision of the estimates deteriorates. However, their magnitude remains very close to that from the baseline stacked

migration to other cities in the same state had a negative and statistically significant effect only on public spending per capita, while all other political variables were not affected.

${ }^{12}$ Since I always use a leave-out version of the instrument, for this story to be a problem, one would need shocks to e.g. New York City to affect migration to other cities within the state of New York, but outside the New York City MSA. 
first difference specification (see Table D7, Panel A). ${ }^{13}$

Finally, Panel D of Table D6 replicates the analysis replacing actual aggregate migration flows using the measure of predicted immigration that only exploits temperature and precipitation shocks in origin countries $\left(\hat{O}_{j t}\right.$ in $(B 8)$ above). Results are consistent with those obtained in the baseline specification, even if in some cases they are an order of magnitude larger, especially for tax rates (column 2) and employment (column 5).

\section{D4 Serial Correlation in National Migration Flows}

The recent work by Jaeger et al. (2018) shows that, for the post 1970 period, the shiftshare instrument might conflate the long and the short run effects of immigration, because there is a very high serial correlation (between 0.95 and 0.99 ) in the sending-destination migration patterns. Said differently, high immigration cities like Los Angeles have been receiving immigrants from the same sources (Mexico) in all decades between 1970 and 2000. Since the economy might react with a lag to the inflow of immigrants, such serial correlation might bias the standard shift-share instrument, which identifies a mix of contemporaneous and lagged effects of immigration.

In Figures D3 and D4, I show that this concern is unlikely to hold in my setting. Due to the national shocks - WWI and Immigration Acts - occurring during this period, there were large and unexpected changes in immigration from different countries (see Section 2 in the main text). Figure D3 plots the serial correlation in the share of immigrants from each European country entering the US over time. With the partial exception of Italy and Russia, the major sending countries in the 1900s and 1910s were quite different from the main sending countries in the 1920s. This is also documented in Figure D4: until the Immigration Acts, most immigrants came from Eastern and Southern Europe. Yet, this pattern was reversed in the 1920s. Similarly, immigration from Germany experienced a dip in the 1910s due to WWI, but then rebounded during the 1920s, once the "German scare" (Fouka, 2018; Higham, 1955) was over.

Directly investigating the serial correlation in immigration across cities in my sample, I found that this number was in the order of 0.7. According to Jaeger et al. (2018), this value is sufficiently low for the shift-share instrument to be unlikely to conflate the long and the short run effects of immigration. Consistent with this idea, in Table D8, I report results for specifications where the contemporaneous (columns 1 and 2) and the lagged (columns 3 and 4) values of the actual fraction of immigrants are regressed against the contemporaneous and the lagged values of the instrument. Once city and state by year fixed effects are included

\footnotetext{
${ }^{13}$ As noted above, the only case in which results are not robust to the use of the stacked first difference specification is for the Democrats' vote share.
} 
(as in all specifications in the paper), only the contemporaneous value of the instrument is significantly correlated with the contemporaneous value of the actual fraction of immigrants. Also, and reassuringly, the correlation between the lagged fraction of immigrants is more precisely estimated and an order of magnitude larger for the lagged value of the instrument relative to the contemporaneous one.

Taken together, these patterns suggest that the critiques to shift-share instruments raised by Jaeger et al. (2018) are unlikely to apply to this context. Further corroborating this idea, in appendix D5.3 below, I show that all results are unchanged when the fraction of all immigrants (irrespective of their arrival year) is instrumented with the contemporaneous and the lagged values of the instrument, using a strategy akin to that in Burchardi et al. (2019).

\section{D5 Outliers and Alternative Specifications}

In this section, I show that results are robust to: $i$ ) dropping potential outliers (Section D5.1); ii) constructing the fraction of immigrants using different denominators (Section D5.2); and iii) considering not only European immigrants arrived in the previous decade (Section D5.3).

\section{D5.1 Outliers}

First, I check that results are not driven by the city of Passaic (NJ), which often appeared as a potential outlier in the scatterplots presented in the main paper (e.g. Figures 4 and A9), or by other cities with extreme values (either high or low) of immigration. In Table D9, I start by replicating each of the specifications for the first stage reported in Tables 2 and B1 by dropping Passaic (NJ). Reassuringly, coefficients always remain highly significant and quantitatively close to those presented in Table 2 and, in all cases, the F-stat is above conventional levels. Figure D5 replicates Figure 4 in the paper, plotting the relationship between the fraction of immigrants and the instrument, after partialling out city and state by year fixed effects (column 3 in Table D9). Then, in Table D10, I replicate Tables 2 and B1 by excluding cities in the $1^{\text {st }}$ (Flint, MI, and Pasadena, CA) and $99^{\text {th }}$ (Passaic, NJ, and Perth Amboy, NJ) percentiles of the 1910 to 1930 change in immigration. As for Table D9, all results remain in line with those reported in the main text. ${ }^{14}$

Next, in Table D11, I assess the robustness of second stage estimates for the key political and economic outcomes. Panel A reports the baseline specification, Panel B drops the city of Passaic, and Panel C omits cities in the $1^{\text {st }}$ and $99^{\text {th }}$ percentiles of the 1910 to 1930 change

\footnotetext{
${ }^{14}$ Very similar results are obtained when trimming the top and bottom percentiles of the 1900 fraction of immigrants.
} 
in immigration. As in Tables D9 and D10, reassuringly, all results remain in line with those obtained for the full sample, becoming, if anything, somewhat larger (in absolute value). ${ }^{15}$

\section{D5.2 Scaling the Number of Immigrants in Different Ways}

Since actual city population is likely to be an outcome of immigration, in my baseline specification I present results where the actual and the predicted number of immigrants are both scaled by predicted city population, constructed by multiplying 1900 population with average urban growth in the US, excluding the Census division where the city is located. In Table D12, I present results obtained scaling the number of immigrants using different population measures. First, in Panel B, both the actual and the predicted number of immigrants is scaled by 1900 city population. Second, in Panel C, I replicate the analysis by scaling the actual number of immigrants with actual city population, while instrumenting it with the predicted number of immigrants over predicted city population, i.e. $Z_{c s t}$ in (2) in the main text. Reassuringly, in both cases, results remain close to those estimated in the main text, and reported in Panel A of Table D12.

\section{D5.3 Immigrants' Stock and Immigrants from Any Source}

As discussed in the main text, in my baseline specification, I only consider European immigrants that entered the United States in the previous decade. However, one may be worried that the effects of recently arrived foreign born differ from those of "long-term" immigrants. For this reason, in Panel A of Table D13, I repeat the analysis considering the fraction of all foreign born individuals, and not only those arrived in the previous ten years. To instrument for immigrants' stock, I adopt a strategy very similar to that in Burchardi et al. (2019): at any point in time, the number of foreign born in a given city is predicted by interacting 1900 shares (i.e. $\alpha_{j c}$ in equation (2) in the main text) with both current and lagged aggregate migration flows (from each sending region). This strategy is also akin to the "double instrumentation" procedure suggested by Jaeger et al. (2018) to isolate the component of immigration uncorrelated with both current demand and past supply shocks.

Reassuringly, results remain very similar to those obtained using only recent immigrants. As a further check, Panel B of Table D13 considers (recently arrived) immigrants from all source countries, and not only from Europe. As expected, results are barely affected.

\footnotetext{
${ }^{15}$ Results, not reported for brevity, also remain very similar to those from my baseline specification when using the $\mathrm{Li}$ (1985) procedure to downweight outliers.
} 


\section{D6 Non-Linear Effects and Relative vs Absolute Size}

\section{D6.1 Non-Linear Effects}

In the paper, I run linear regressions to estimate the effects of immigration on political and economic outcomes. However, it is possible that immigration affected both political and economic conditions across US cities in a non-linear way. To explore this possibility, in Figures D6 and D7, I plot the relationship between the inflow of immigrants and the eight main outcomes considered in the paper, without restricting the functional form to be linear. In particular, I first regress non-parametrically the 1910-1930 change in each of the outcomes and in the instrument on state dummies. Next, I predict the residuals, and plot non-parametrically the residualized change in each of the outcomes against the residualized change in the instrument. ${ }^{16}$

Figure D6 presents results for political outcomes: in all cases, except for public spending per capita, the relationship between (predicted) immigration and political reactions appears to be linear (or, close to linear). For public spending, instead, there seems to be evidence of a non-linear - and in particular, quadratic - relationship. Also in this case, however, a linear approximation seems to perform quite well. Next, Figure D7 plots the equivalent graphs of D6, focusing on economic outcomes. Also in this case, the economic effects of immigration seem to be well approximated by a linear functional form.

As discussed above, Passaic (NJ) appears to be an outlier, and one may be concerned that some of the results might be unduly affected by this city. In Figures D8 and D9, I replicate the analysis presented in Figures D6 and D7 omitting this city. Reassuringly, all results remain very similar to the full-sample specification. In unreported results, I also estimated regressions interacting the main effect of immigration with a dummy equal to 1 for cities with the fraction of immigrants above the $75^{\text {th }}$ percentile. While this reduced the precision of results, the coefficient on the main effect remained in line with that estimated in the paper, while that on the interaction term was never statistically significant. I also replicated this with other values for potentially "salient thresholds", but I never detected a statistically significant and consistent pattern. My interpretation is that these findings, together with Figures D6 to D9, indicate that the effects of immigration were unlikely to be non-linear.

\footnotetext{
${ }^{16}$ Note that an equivalent way of doing this would be to run (non-parametric) regressions stacking the data and partialling out city and state by year fixed effects (as I do in the paper for linear regressions). Here, I preferred to perform this exercise in changes to make graphs easier to read and interpret. However, all results are very similar when stacking the data and estimating panel regressions.
} 


\section{D6.2 Absolute vs Relative Size}

In the paper, I showed that a higher fraction of immigrants triggered political backlash despite their economic benefits. It is possible that the absolute numbers (or levels) of immigrants mattered too. Especially in the housing market and in the allocation of public spending, the (absolute) number of immigrants might be even more likely to generate congestion costs than their shares. To explore this possibility, in Panel B of Table D14, I repeat the analysis using as main regressor of interest the log of the number of immigrants, separately controlling for the log of city population. ${ }^{17}$ To ease comparisons, Panel A presents the coefficients estimated in the paper for the effects of the fraction of immigrants.

Starting from the political effects of immigration, while results become somewhat less precise, also when using a specification in logs, immigration triggers hostile political reactions. The only exception is the property tax rate (column 2): the log of immigrant population has no longer a statistically significant effect, and the coefficient becomes positive. However, given the size of the standard errors, it is impossible to make any conclusive statement in this case. Turning to economic outcomes, as it appears from columns 5 to 8, even when considering a specification in logs, immigration had a positive, statistically significant, and economically relevant effect on natives' employment and on economic activity.

Summing up, results estimated in the paper are robust to a specification in logs, suggesting that both the relative and the absolute size of immigrant groups mattered (both for political and for economic outcomes).

\section{D7 Selection on Observables and Unobservables}

In Table D15, I explore the stability of coefficients using the methodology proposed in Oster (2017), which allows for different assumptions on bias due to selection on observables and unobservables. Since my baseline specification already controls for city and state by year fixed effects, and relies on an instrumental variable procedure, I first residualize all outcomes as well as predicted immigration by regressing them (separately) on city dummies and on interactions between year and state dummies. Column 1 of Table D15 reports the coefficient for reduced form regressions of each residualized outcome on the residualized instrument. ${ }^{18}$ Here, I also report the R-squared of the baseline specification in square brackets.

Next, in column 2, I report the estimates for a model where the baseline (residualized) specification of column 1 is augmented with interactions between year dummies and all

\footnotetext{
${ }^{17}$ Results are unchanged when separately controlling for the log of predicted (rather than actual) city population.

${ }^{18}$ As usual, standard errors are reported in parentheses.
} 
the controls used to test the robustness of results (see online appendix D1, and Tables D2 and D3). ${ }^{19}$ Following the terminology in Oster (2017), I refer to this as the "full controls" specification. As already documented in Tables D2 and D3 above, most coefficients remain quantitatively close to those estimated in the baseline specification. ${ }^{20}$ The only exception occurs for the Democrats' vote share in Presidential elections, which is not robust to the inclusion of interactions between year dummies and the 1900 immigrant and city population.

Finally, in column 3 of Table D15, I apply the adjustment strategy proposed by Oster (2017). I impose the most conservative estimate for $R_{\max }$, equal to $1.3^{*} R 2_{c}$, where $R 2_{c}$ is the R-squared of the "full controls" model. Following Oster (2017), I define the relative degree of selection on observables and unobservables $\delta$, and assume a value for it equal to 1 , but results remain almost identical when setting $\delta$ lower than 1 (as for $R_{\text {max }}$, I chose the value of $\delta$ that would provide the most stringent test). Reassuringly, except for the Democrats' vote share and, to some extent, the DW Nominate scores, all point estimates remain quantitatively very close to those estimated in the baseline model even when using the adjustment procedure from Oster (2017). These findings suggest that the stability of coefficients does not depend on specific assumptions about selection on unobservables.

\section{D8 Additional Robustness Checks}

\section{D8.1 Cross-Sectional Regressions for Legislators' Ideology}

In Section 5.3.2 of the paper, I investigate the relationship between the 1910 to 1920 change in immigration and votes of members of the House of Representatives on the 1924 National Origins Act. Since I examine voting behavior at a specific point in time, my analysis for this outcome relies on a cross-sectional regression, implying that city and state by year fixed effects cannot be included. To indirectly assess the size and the direction of the bias that this may generate, in Table D16, I replicate columns 1 and 3 to 6 of Table 4 using cross-sectional regressions. To mirror as close as possible the specification reported in columns 7 and 8 of Table 4, 1920 DW Nominate scores are regressed against the 1910 to 1920 (instrumented) change in the fraction of immigrants and on state fixed effects.

Results from this exercise, reported in Panel B of Table D16, are similar to those from the baseline specification, which, to ease comparisons, are presented in Panel A. While only suggestive, the estimates in Table D16 indicate that failing to include city and state by year

\footnotetext{
${ }^{19}$ Specifically, these variables are the pre-period: log of immigrant and city population; skill ratios; fraction of blacks; log of value added by manufacturing per establishment; log of the value of products per establishment; share of employment in manufacturing.

${ }^{20}$ In a few instances, such as for tax rates or DW Nominate scores, however, coefficients are no longer statistically significant at conventional levels.
} 
fixed effects, at least for this set of outcomes, does not seem to introduce substantial bias in 2SLS estimates.

\section{D8.2 Presidential Elections}

Finally, in Table D17, I replicate the electoral results presented in Table 3 (column 3) and Table A6 above by computing vote shares and turnout by taking the average between the two closest election years rather than between the two elections after each Census year (Panel A), and excluding MSAs in the US South (Panel B). In both cases, results remain in line with those presented in the main text. 


\section{Table D1. Checking for Pre-Trends}

\begin{tabular}{|c|c|c|c|c|c|c|c|c|}
\hline VARIABLES & $\begin{array}{c}\text { (1) } \\
\text { Public } \\
\text { Spending PC } \\
\end{array}$ & $\begin{array}{l}(2) \\
\text { Prop. Tax } \\
\text { Rate } \\
\end{array}$ & $\begin{array}{c}(3) \\
\text { Democrats' } \\
\text { Vote Share }\end{array}$ & $\begin{array}{c}(4) \\
\text { DW Nominate } \\
\text { Scores } \\
\end{array}$ & $\begin{array}{c}(5) \\
\text { Employed }\end{array}$ & $\begin{array}{c}(6) \\
\text { Log Occ. } \\
\text { Scores } \\
\end{array}$ & $\begin{array}{c}\text { (7) } \\
\text { Log Value Added } \\
\text { per Establ. }\end{array}$ & $\begin{array}{c}(8) \\
\text { Log Establ. } \\
\text { Size } \\
\end{array}$ \\
\hline \multicolumn{9}{|c|}{ Panel A. Baseline Specification } \\
\hline Fr. Immigrants & $\begin{array}{l}-8.699 * \\
(4.453)\end{array}$ & $\begin{array}{c}-29.44 * \\
(16.95)\end{array}$ & $\begin{array}{c}-0.404 * * * \\
(0.141)\end{array}$ & $\begin{array}{c}1.658 * * \\
(0.808)\end{array}$ & $\begin{array}{c}0.299 * * * \\
(0.064)\end{array}$ & $\begin{array}{c}0.097 * * * \\
(0.036)\end{array}$ & $\begin{array}{c}2.889 * * * \\
(0.954)\end{array}$ & $\begin{array}{c}2.532 * * * \\
(0.815)\end{array}$ \\
\hline F-stat & 288.3 & 292.7 & 83.14 & 23.11 & 251.3 & 251.3 & 270.5 & 270.5 \\
\hline Observations & 540 & 539 & 378 & 460 & 538 & 538 & 525 & 525 \\
\hline \multicolumn{9}{|c|}{ Panel B. Dep. Variable is 1910-1900 Change } \\
\hline Fr. Immigrants & $\begin{array}{c}0.460 \\
(4.135)\end{array}$ & $\begin{array}{l}-4.204 \\
(8.224)\end{array}$ & $\begin{array}{l}-0.147 \\
(0.157)\end{array}$ & $\begin{array}{c}0.052 \\
(0.909)\end{array}$ & $\begin{array}{l}-0.117 \\
(0.112)\end{array}$ & $\begin{array}{c}0.026 \\
(0.066)\end{array}$ & $\begin{array}{c}0.031 \\
(0.414)\end{array}$ & $\begin{array}{c}0.051 \\
(0.458)\end{array}$ \\
\hline F-stat & 318.3 & 320.6 & 64.54 & 25.92 & 313.0 & 313.0 & 272.6 & 272.6 \\
\hline Observations & 180 & 179 & 123 & 135 & 180 & 180 & 176 & 176 \\
\hline
\end{tabular}

\section{Table D2. Differential Trends/1}

\begin{tabular}{|c|c|c|c|c|c|c|c|c|}
\hline VARIABLES & $\begin{array}{c}(1) \\
\text { Public } \\
\text { Spending PC }\end{array}$ & $\begin{array}{c}(2) \\
\text { Prop. Tax } \\
\text { Rate } \\
\end{array}$ & $\begin{array}{c}(3) \\
\text { Democrats' Vote } \\
\text { Share } \\
\end{array}$ & $\begin{array}{c}(4) \\
\text { DW Nominate } \\
\text { Scores } \\
\end{array}$ & $\begin{array}{c}5) \\
\text { Employed }\end{array}$ & $\begin{array}{c}(6) \\
\text { Log Occ. } \\
\text { Scores }\end{array}$ & $\begin{array}{c}(7) \\
\text { Log Value Added } \\
\text { per Establ. }\end{array}$ & $\begin{array}{c}(8) \\
\text { Log Establ. } \\
\text { Size } \\
\end{array}$ \\
\hline \multicolumn{9}{|c|}{ Panel A: Baseline Specification } \\
\hline Fr. Immigrants & $\begin{array}{l}-8.699^{*} \\
(4.453)\end{array}$ & $\begin{array}{l}-29.44 * \\
(16.95)\end{array}$ & $\begin{array}{c}-0.404 * * * \\
(0.141)\end{array}$ & $\begin{array}{l}1.658 * * \\
(0.808)\end{array}$ & $\begin{array}{c}0.299^{*} * * * \\
(0.064)\end{array}$ & $\begin{array}{c}0.097 * * * \\
(0.036)\end{array}$ & $\begin{array}{c}2.889 * * * \\
(0.954)\end{array}$ & $\begin{array}{c}2.532^{* * *} \\
(0.815)\end{array}$ \\
\hline F-stat & 288.3 & 292.7 & 83.14 & 23.11 & 251.3 & 251.3 & 270.5 & 270.5 \\
\hline \multicolumn{9}{|c|}{ Panel B: Predicted Industrialization } \\
\hline Fr. Immigrants & $\begin{array}{c}-12.47 * * * * \\
(4.759)\end{array}$ & $\begin{array}{l}-30.80^{*} \\
(18.72)\end{array}$ & $\begin{array}{c}-0.375^{* *} \\
(0.158)\end{array}$ & $\begin{array}{l}1.529 * \\
(0.855)\end{array}$ & $\begin{array}{c}0.288 * * * \\
(0.070)\end{array}$ & $\begin{array}{c}0.098^{* * * *} \\
(0.035)\end{array}$ & $\begin{array}{c}2.884 * * * \\
(1.014)\end{array}$ & $\begin{array}{c}2.532 * * * \\
(0.843)\end{array}$ \\
\hline F-stat & 234.3 & 239.3 & 76.10 & 22.16 & 207.3 & 207.3 & 216.0 & 216.0 \\
\hline \multicolumn{9}{|c|}{ Panel C: Immigrant and City Pop. } \\
\hline Fr. Immigrants & $\begin{array}{c}-12.01 * * \\
(5.490)\end{array}$ & $\begin{array}{l}-21.42 \\
(21.22)\end{array}$ & $\begin{array}{c}0.169 \\
(0.271)\end{array}$ & $\begin{array}{l}1.760^{*} \\
(1.025)\end{array}$ & $\begin{array}{c}0.226 * * * \\
(0.061)\end{array}$ & $\begin{array}{l}0.082^{*} \\
(0.042)\end{array}$ & $\begin{array}{c}2.465^{* *} \\
(1.073)\end{array}$ & $\begin{array}{l}1.945^{* *} \\
(0.931)\end{array}$ \\
\hline F-stat & 96.48 & 97.37 & 35.64 & 10.75 & 82.91 & 82.91 & 89.38 & 89.38 \\
\hline \multicolumn{9}{|c|}{ Panel D: Value Added Manufacturing } \\
\hline Fr. Immigrants & $\begin{array}{c}-17.18^{* * * *} \\
(4.421)\end{array}$ & $\begin{array}{l}-19.38 \\
(19.73)\end{array}$ & $\begin{array}{l}-0.271 \\
(0.169)\end{array}$ & $\begin{array}{c}2.403 \\
(1.507)\end{array}$ & $\begin{array}{c}0.280 * * * \\
(0.081)\end{array}$ & $\begin{array}{c}0.112 * * * \\
(0.039)\end{array}$ & $\begin{array}{c}2.423 * * \\
(1.113)\end{array}$ & $\begin{array}{c}2.590 * * * \\
(0.972)\end{array}$ \\
\hline F-stat & 124.8 & 124.2 & 67.73 & 34.13 & 107.5 & 107.5 & 124.7 & 124.7 \\
\hline
\end{tabular}




\section{Table D3. Differential Trends/2}

\begin{tabular}{|c|c|c|c|c|c|c|c|c|}
\hline VARIABLES & $\begin{array}{c}(1) \\
\text { Public } \\
\text { Spending PC } \\
\end{array}$ & $\begin{array}{c}(2) \\
\text { Prop. Tax } \\
\text { Rate } \\
\end{array}$ & $\begin{array}{c}(3) \\
\text { Democrats' Vote } \\
\text { Share } \\
\end{array}$ & $\begin{array}{c}(4) \\
\text { DW Nominate } \\
\text { Scores } \\
\end{array}$ & $\begin{array}{c}\text { (5) } \\
\text { Employed }\end{array}$ & $\begin{array}{c}(6) \\
\text { Log Occ. } \\
\text { Scores }\end{array}$ & $\begin{array}{c}(7) \\
\text { Log Value Added } \\
\text { per Establ. }\end{array}$ & $\begin{array}{c}(8) \\
\text { Log Establ. } \\
\text { Size } \\
\end{array}$ \\
\hline \multicolumn{9}{|c|}{ Panel A: Skill Ratios } \\
\hline Fr. Immigrants & $\begin{array}{l}-8.257^{*} \\
(4.686)\end{array}$ & $\begin{array}{l}-29.52^{*} \\
(17.00)\end{array}$ & $\begin{array}{c}-0.393^{* * * *} \\
(0.142)\end{array}$ & $\begin{array}{l}1.614 * * \\
(0.821)\end{array}$ & $\begin{array}{c}0.294 * * * \\
(0.065)\end{array}$ & $\begin{array}{c}0.101 * * * \\
(0.035)\end{array}$ & $\begin{array}{c}2.879 * * * \\
(0.948)\end{array}$ & $\begin{array}{c}2.520 * * * \\
(0.816)\end{array}$ \\
\hline F-stat & 258.8 & 260.3 & 83.60 & 25.33 & 223.8 & 223.8 & 247.1 & 247.1 \\
\hline $\begin{array}{l}\text { Panel B: Fracti } \\
\text { Fr. Immigrants }\end{array}$ & $\begin{array}{l}\text { of Blacks } \\
-9.968^{* *} \\
(4.480)\end{array}$ & $\begin{array}{l}-27.25 \\
(16.94)\end{array}$ & $\begin{array}{c}-0.384 * * * \\
(0.146)\end{array}$ & $\begin{array}{l}1.756^{* *} \\
(0.794)\end{array}$ & $\begin{array}{c}0.286^{* * * *} \\
(0.063)\end{array}$ & $\begin{array}{c}0.092 * * \\
(0.036)\end{array}$ & $\begin{array}{c}3.009 * * * \\
(1.006)\end{array}$ & $\begin{array}{c}2.825 * * * \\
(0.920)\end{array}$ \\
\hline F-stat & 269.7 & 273.8 & 76.74 & 24.06 & 235.1 & 235.1 & 249.9 & 249.9 \\
\hline $\begin{array}{l}\text { Panel C: Value } \\
\text { Fr. Immigrants }\end{array}$ & $\begin{array}{l}\text { Products } \\
-17.19 * * * \\
\text { (4.752) }\end{array}$ & $\begin{array}{l}-19.63 \\
(20.15)\end{array}$ & $\begin{array}{l}-0.226 \\
(0.179)\end{array}$ & $\begin{array}{c}2.302 \\
(1.550)\end{array}$ & $\begin{array}{c}0.265^{* * * *} \\
(0.075)\end{array}$ & $\begin{array}{c}0.108 * * * \\
(0.038)\end{array}$ & $\begin{array}{c}2.642^{* * *} \\
(1.189)\end{array}$ & $\begin{array}{c}2.690 * * \\
(1.054)\end{array}$ \\
\hline F-stat & 130.6 & 130.7 & 34.89 & 37.73 & 112.9 & 112.9 & 128.6 & 128.6 \\
\hline $\begin{array}{l}\text { Panel D: Emplo } \\
\text { Fr. Immigrants }\end{array}$ & $\begin{array}{c}\text { tent Share Ma } \\
-15.45^{* * *} * \\
(4.455)\end{array}$ & $\begin{array}{l}\text { Ifacture } \\
\quad-20.47 \\
(22.37)\end{array}$ & $\begin{array}{c}-0.407 * * * \\
(0.146)\end{array}$ & $\begin{array}{l}2.310^{*} \\
(1.247)\end{array}$ & $\begin{array}{c}0.284 * * * \\
(0.092)\end{array}$ & $\begin{array}{c}0.127 * * * \\
(0.044)\end{array}$ & $\begin{array}{c}3.220 * * * \\
(1.118)\end{array}$ & $\begin{array}{c}2.860 * * * \\
(0.941)\end{array}$ \\
\hline F-stat & 230.5 & 232.0 & 60.27 & 34.45 & 204.7 & 204.7 & 222.3 & 222.3 \\
\hline
\end{tabular}

\section{Table D4. Full Sample vs Cities with 1904 Industrial Data}

\begin{tabular}{|c|c|c|c|c|c|c|c|c|}
\hline VARIABLES & $\begin{array}{c}(1) \\
\text { Public } \\
\text { Spending PC } \\
\end{array}$ & $\begin{array}{l}(2) \\
\text { Prop. Tax } \\
\text { Rate } \\
\end{array}$ & $\begin{array}{c}\text { (3) } \\
\text { Democrats' Vote } \\
\text { Share } \\
\end{array}$ & $\begin{array}{c}\text { (4) } \\
\text { DW Nominate } \\
\text { Scores } \\
\end{array}$ & $\begin{array}{c}(5) \\
\text { Employed }\end{array}$ & $\begin{array}{c}(6) \\
\text { Log Occ. } \\
\text { Scores } \\
\end{array}$ & $\begin{array}{c}\text { (7) } \\
\text { Log Value Added } \\
\text { per Establ. }\end{array}$ & $\begin{array}{c}(8) \\
\text { Log Establ. } \\
\text { Size } \\
\end{array}$ \\
\hline \multicolumn{9}{|c|}{ Panel A: Full Sample } \\
\hline Fr. Immigrants & $\begin{array}{l}-8.699 * \\
(4.453)\end{array}$ & $\begin{array}{c}-29.44 * \\
(16.95)\end{array}$ & $\begin{array}{c}-0.404 * * * \\
(0.141)\end{array}$ & $\begin{array}{c}1.658 * * \\
(0.808)\end{array}$ & $\begin{array}{c}0.299 * * * \\
(0.064)\end{array}$ & $\begin{array}{c}0.097 * * * \\
(0.036)\end{array}$ & $\begin{array}{c}2.889 * * * \\
(0.954)\end{array}$ & $\begin{array}{c}2.532 * * * \\
(0.815)\end{array}$ \\
\hline F-stat & 288.3 & 292.7 & 83.14 & 23.11 & 251.3 & 251.3 & 270.5 & 270.5 \\
\hline Cities & 180 & 180 & 126 & 157 & 180 & 180 & 178 & 178 \\
\hline Observations & 540 & 539 & 378 & 460 & 538 & 538 & 525 & 525 \\
\hline \multicolumn{9}{|c|}{ Panel B: Drop Cities without 1904 Industrial Data } \\
\hline Fr. Immigrants & $\begin{array}{c}-13.38 * * * \\
(3.840)\end{array}$ & $\begin{array}{l}-20.85 \\
(18.55)\end{array}$ & $\begin{array}{c}-0.415^{* * *} \\
(0.140)\end{array}$ & $\begin{array}{l}2.159 * \\
(1.291)\end{array}$ & $\begin{array}{c}0.287 * * * \\
(0.074)\end{array}$ & $\begin{array}{c}0.109 * * * \\
(0.038)\end{array}$ & $\begin{array}{c}2.964 * * * \\
(1.038)\end{array}$ & $\begin{array}{c}2.715 * * * \\
(0.838)\end{array}$ \\
\hline F-stat & 247.9 & 251.3 & 83.75 & 42.17 & 216.6 & 216.6 & 240 & 240 \\
\hline Cities & 176 & 176 & 126 & 154 & 176 & 176 & 176 & 176 \\
\hline Observations & 528 & 527 & 378 & 451 & 526 & 526 & 519 & 519 \\
\hline
\end{tabular}

Note: this table replicates the baseline specification comparing the full sample (Panel A) with the sample of cities for which 1904 industrial data were reported in the 1904 Census of Manufacture (Panel B). The 4 cities for which industrial data is not available are: Pasadena (CA), Perth Amboy (NJ), Superior (WI), and Washington D.C. The dependent variable is displayed at the top of each column. *** $\mathrm{p}<0.01 ; * * \mathrm{p}<0.05 ; * \mathrm{p}<0.1$. 


\section{Table D5. Testing for Spillovers}

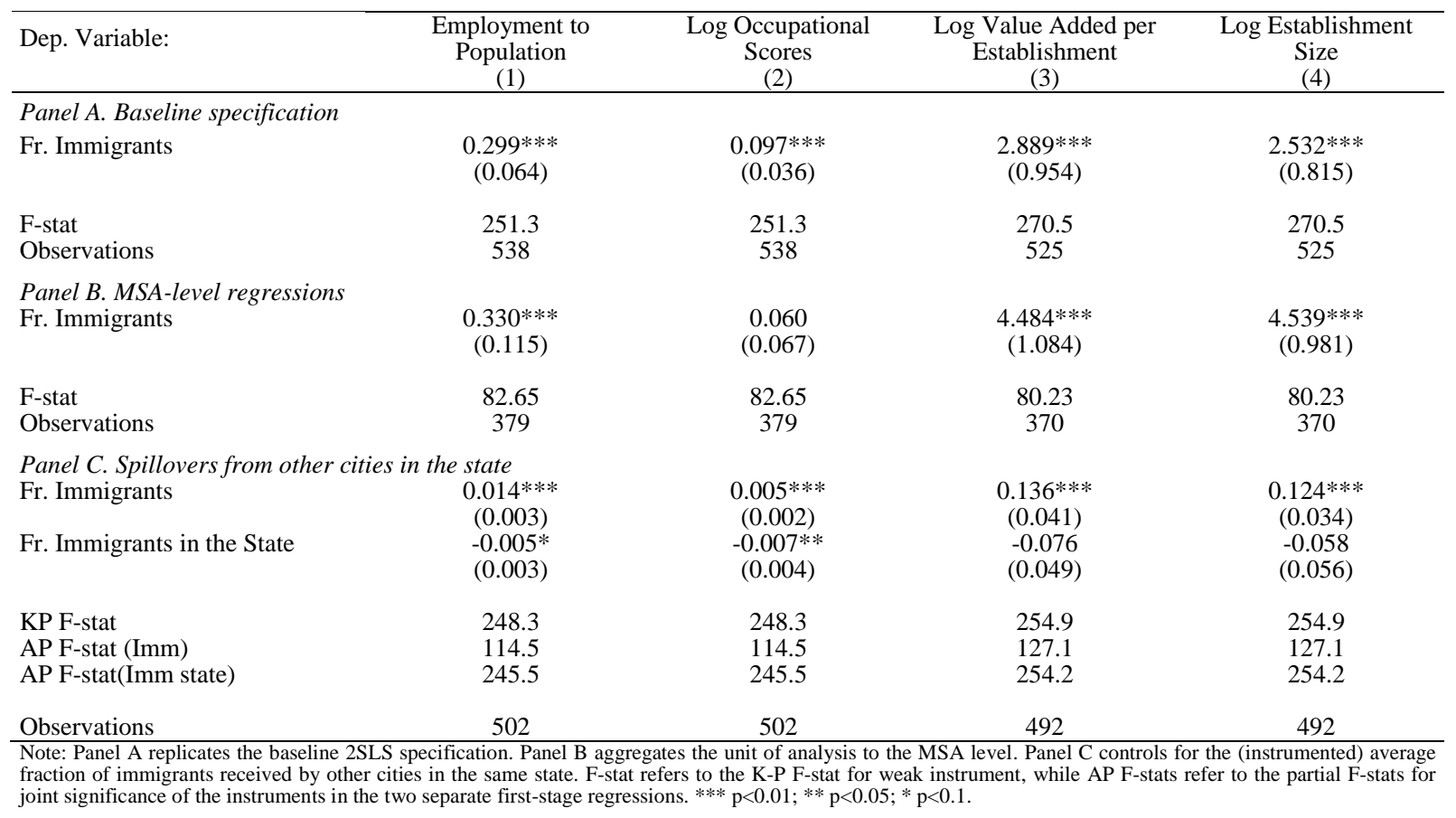

\section{Table D6. Quota and WWI and Weather Shock Instruments}

\begin{tabular}{|c|c|c|c|c|c|c|c|c|}
\hline VARIABLES & $\begin{array}{c}(1) \\
\text { Public } \\
\text { Spending PC }\end{array}$ & $\begin{array}{c}(2) \\
\text { Prop. Tax } \\
\text { Rate } \\
\end{array}$ & $\begin{array}{c}\text { (3) } \\
\text { Democrats' } \\
\text { Vote Share }\end{array}$ & $\begin{array}{c}(4) \\
\text { DW Nominate } \\
\text { Scores }\end{array}$ & $\begin{array}{c}\text { (5) } \\
\text { Employed }\end{array}$ & $\begin{array}{c}(6) \\
\text { Log Occ. } \\
\text { Scores }\end{array}$ & $\begin{array}{c}\text { (7) } \\
\begin{array}{c}\text { Log Value Added } \\
\text { per Establ. }\end{array}\end{array}$ & $\begin{array}{c}(8) \\
\text { Log Establ. } \\
\text { Size } \\
\end{array}$ \\
\hline \multicolumn{9}{|c|}{ Panel A: Baseline Specification } \\
\hline Fr. Immigrants & $\begin{array}{l}-8.699 * \\
(4.453)\end{array}$ & $\begin{array}{l}-29.44 * \\
(16.95)\end{array}$ & $\begin{array}{c}-0.404 * * * \\
(0.141)\end{array}$ & $\begin{array}{l}1.658^{* *} \\
(0.808)\end{array}$ & $\begin{array}{c}0.299 * * * \\
(0.064)\end{array}$ & $\begin{array}{c}0.097 * * * \\
(0.036)\end{array}$ & $\begin{array}{c}2.889 * * * \\
(0.954)\end{array}$ & $\begin{array}{c}2.532 * * * \\
(0.815)\end{array}$ \\
\hline F-stat & 288.3 & 292.7 & 83.14 & 23.11 & 251.3 & 251.3 & 270.5 & 270.5 \\
\hline \multicolumn{9}{|c|}{ Panel B: Stacked $1^{\text {st }}$ Differences } \\
\hline Fr. Immigrants & $\begin{array}{l}-5.739^{*} \\
(2.970)\end{array}$ & $\begin{array}{l}-24.29 \\
(19.35)\end{array}$ & $\begin{array}{c}0.048 \\
(0.162)\end{array}$ & $\begin{array}{l}1.939 * * \\
(0.773)\end{array}$ & $\begin{array}{c}0.213 * * * \\
(0.043)\end{array}$ & $\begin{array}{l}0.082 * * \\
(0.033)\end{array}$ & $\begin{array}{c}1.778 * * * \\
(0.665)\end{array}$ & $\begin{array}{c}1.983 * * * \\
(0.596)\end{array}$ \\
\hline F-stat & 106.8 & 106.2 & 23.43 & 8.693 & 102.2 & 102.2 & 106.0 & 106.0 \\
\hline $\begin{array}{l}\text { Panel C: Long } \\
\text { Fr. Immigrants }\end{array}$ & $\begin{array}{l}\text { ifferences } \\
\quad-11.34^{*} \\
(6.197)\end{array}$ & $\begin{array}{c}-38.16^{* *} \\
(14.88)\end{array}$ & $\begin{array}{c}-0.606 * * * \\
(0.167)\end{array}$ & $\begin{array}{c}1.168 \\
(0.843)\end{array}$ & $\begin{array}{c}0.362 * * * \\
(0.076)\end{array}$ & $\begin{array}{c}0.124 * * * \\
(0.042)\end{array}$ & $\begin{array}{c}2.277 * * * \\
(0.729)\end{array}$ & $\begin{array}{c}2.146 * * * \\
(0.720)\end{array}$ \\
\hline F-stat & 207.4 & 204.5 & 35.76 & 15.39 & 207.4 & 207.4 & 199.4 & 199.4 \\
\hline $\begin{array}{l}\text { Panel D: Weath } \\
\text { Fr. Immigrants }\end{array}$ & $\begin{array}{l}r \text { Shocks } \\
\quad-15.88^{* *} \\
\quad(7.848)\end{array}$ & $\begin{array}{c}-86.07 * \\
(48.12)\end{array}$ & $\begin{array}{l}-0.387 * \\
(0.230)\end{array}$ & $\begin{array}{c}2.205 * * \\
(1.042)\end{array}$ & $\begin{array}{c}0.480 * * * \\
(0.113)\end{array}$ & $\begin{array}{c}0.141 * * \\
(0.060)\end{array}$ & $\begin{array}{c}2.171^{* *} \\
(0.969)\end{array}$ & $\begin{array}{l}1.924 * \\
(0.983)\end{array}$ \\
\hline F-stat & 18.70 & 18.72 & 28.17 & 14.39 & 15.68 & 15.68 & 18.28 & 18.28 \\
\hline
\end{tabular}




\section{Table D7. Quota and WWI Instrument: Interactions}

\begin{tabular}{|c|c|c|c|c|c|c|c|c|}
\hline VARIABLES & $\begin{array}{c}\text { (1) } \\
\text { Public } \\
\text { Spending PC } \\
\end{array}$ & $\begin{array}{l}(2) \\
\text { Prop. Tax } \\
\text { Rate } \\
\end{array}$ & $\begin{array}{c}\text { (3) } \\
\text { Democrats' } \\
\text { Vote Share } \\
\end{array}$ & $\begin{array}{c}(4) \\
\text { DW Nominate } \\
\text { Scores } \\
\end{array}$ & $\begin{array}{c}(5) \\
\text { Employed }\end{array}$ & $\begin{array}{c}(6) \\
\text { Log Occ. } \\
\text { Scores } \\
\end{array}$ & $\begin{array}{c}\text { (7) } \\
\text { Log Value Added } \\
\text { per Establ. }\end{array}$ & $\begin{array}{c}(8) \\
\text { Log Establ. } \\
\text { Size } \\
\end{array}$ \\
\hline \multicolumn{9}{|c|}{ Panel A: Baseline Stacked $1^{\text {st }}$ Differences } \\
\hline Fr. Immigrants & $\begin{array}{l}-5.739^{*} \\
(2.970)\end{array}$ & $\begin{array}{l}-24.29 \\
(19.35)\end{array}$ & $\begin{array}{c}0.048 \\
(0.162)\end{array}$ & $\begin{array}{l}1.939 * * \\
(0.773)\end{array}$ & $\begin{array}{c}0.213 * * * \\
(0.043)\end{array}$ & $\begin{array}{c}0.082^{* *} \\
(0.033)\end{array}$ & $\begin{array}{c}1.778 * * * \\
(0.665)\end{array}$ & $\begin{array}{c}1.983 * * * \\
(0.596)\end{array}$ \\
\hline F-stat & 106.8 & 106.2 & 23.43 & 8.693 & 102.2 & 102.2 & 106.0 & 106.0 \\
\hline \multicolumn{9}{|c|}{ Panel B: Stacked $1^{\text {st }}$ Differences AND Year by 1900 City and Immigrants Pop. } \\
\hline Fr. Immigrants & $\begin{array}{l}-7.790 \\
(5.080)\end{array}$ & $\begin{array}{l}-20.45 \\
(23.84)\end{array}$ & $\begin{array}{l}-0.069 \\
(0.197)\end{array}$ & $\begin{array}{l}1.735^{*} \\
(1.046)\end{array}$ & $\begin{array}{c}0.205 * * * \\
(0.055)\end{array}$ & $\begin{array}{l}0.087 * \\
(0.047)\end{array}$ & $\begin{array}{l}1.515 * * \\
(0.724)\end{array}$ & $\begin{array}{l}1.526 * * \\
(0.764)\end{array}$ \\
\hline F-stat & 86.99 & 87.26 & 15.28 & 5.945 & 80.24 & 80.24 & 91.18 & 91.18 \\
\hline
\end{tabular}

\section{Table D8. First Stage: Specification in Jaeger et al. (2018)}

\begin{tabular}{|c|c|c|c|c|}
\hline & \multicolumn{4}{|c|}{ Dep. Variable: Fraction of Immigrants } \\
\hline & (1) & (2) & (3) & (4) \\
\hline & \multicolumn{2}{|c|}{ Contemporaneous } & \multicolumn{2}{|c|}{ Lagged } \\
\hline Instrument & $\begin{array}{c}0.557 * * \\
(0.254)\end{array}$ & $\begin{array}{c}0.677 * * \\
(0.278)\end{array}$ & $\begin{array}{l}0.409 * \\
(0.240)\end{array}$ & $\begin{array}{l}0.696^{*} \\
(0.398)\end{array}$ \\
\hline Lagged Instrument & $\begin{array}{c}0.254 * * * \\
(0.089)\end{array}$ & $\begin{array}{c}0.095 \\
(0.083)\end{array}$ & $\begin{array}{c}1.024 * * * \\
(0.097)\end{array}$ & $\begin{array}{c}0.804 * * * \\
(0.118)\end{array}$ \\
\hline Observations & 360 & 360 & 360 & 360 \\
\hline Fixed Effects & NO & YES & NO & YES \\
\hline
\end{tabular}


Table D9. First Stage Omitting Passaic (NJ)

\begin{tabular}{|c|c|c|c|c|c|c|c|c|}
\hline & \multicolumn{8}{|c|}{ Dep. Variable: Fraction of Immigrants } \\
\hline & $(1)$ & (2) & (3) & $(4)$ & $(5)$ & (6) & (7) & (8) \\
\hline $\mathrm{Z}$ & $\begin{array}{c}0.884 * * * \\
(0.059)\end{array}$ & $\begin{array}{c}0.900 * * * \\
(0.077)\end{array}$ & $\begin{array}{c}0.940 * * * \\
(0.068)\end{array}$ & $\begin{array}{c}0.948 * * * \\
(0.105)\end{array}$ & $\begin{array}{c}0.795 * * * \\
(0.092)\end{array}$ & $\begin{array}{c}0.786 * * * \\
(0.078)\end{array}$ & & \\
\hline$\left(\mathrm{Z} \_W W I\right) * 1920$ & & & & & & & $\begin{array}{c}0.730 * * * \\
(0.146)\end{array}$ & $\begin{array}{c}0.783^{*} * * \\
(0.121)\end{array}$ \\
\hline (Z_Quotas)*1930 & & & & & & & $\begin{array}{c}0.774 * * \\
(0.349)\end{array}$ & $\begin{array}{c}1.246 * * * \\
(0.189)\end{array}$ \\
\hline$\left(Z \_W W I\right) * 1930$ & & & & & & & $\begin{array}{c}0.053 \\
(0.092)\end{array}$ & \\
\hline (Z_Quotas)*1920 $^{2}$ & & & & & & & $\begin{array}{c}0.472 \\
(0.427)\end{array}$ & \\
\hline 1900 population & & $\mathrm{X}$ & & & & & & \\
\hline Predicted population & & & $\mathrm{X}$ & & & & & \\
\hline MSA analysis & & & & $\mathrm{X}$ & & & & \\
\hline Year by $1900 \mathrm{Log}$ & & & & & $\begin{array}{l}\text { City and } \\
\text { imm pop }\end{array}$ & $\begin{array}{l}\text { Value added } \\
\text { manuf. }\end{array}$ & & \\
\hline WWI-Quotas IV & & & & & & & First Diff. & Long Diff. \\
\hline $\begin{array}{l}\text { F-stat } \\
\text { P-value Overid Test }\end{array}$ & 226.4 & 137.0 & 193.2 & 81.88 & 75.38 & 102.0 & $\begin{array}{l}36.31 \\
0.431\end{array}$ & $\begin{array}{l}64.47 \\
0.603\end{array}$ \\
\hline Cities & 179 & 179 & 179 & 127 & 179 & 175 & 179 & 179 \\
\hline Observations & 537 & 537 & 537 & 379 & 537 & 525 & 358 & 179 \\
\hline $\begin{array}{l}\text { Note: this table presents the } \\
\text { and the instrument is the leav } \\
\text { respectively, } 1900 \text { and predi } \\
\text { scaled by predicted populati } \\
\text { respectively, the (log of) } 190 \\
\text { equation (B4) and long differ } \\
\text { in online appendix B1). F-sta } \\
\text { state by year fixed effects. Ro }\end{array}$ & $\begin{array}{l}\text { eplica of Table } \\
\text { t version of the } \\
\text { population. Fr } \\
\text { Col } 4 \text { replicate } \\
\text { ty and immigr } \\
\text { s equation (B6 } \\
\text { ers to the K-P } \\
\text { standard error }\end{array}$ & $\begin{array}{l}\text { - online appe } \\
\text {-share IV in e } \\
\text { ol } 3 \text { onwards, } \\
\text { analysis aggr } \\
\text { pulation, and } \\
\text { acing the stan } \\
\text { for weak ins }\end{array}$ & $\begin{array}{l}\text { B excluding t } \\
\text { on (2) (Sectio } \\
\text { le D9 present } \\
\text { ng the unit o } \\
\text { (log of) } 1904 \\
\text { shift-share in } \\
\text { ent. Cols } 7-8 \\
\text { level, in paren }\end{array}$ & $\begin{array}{l}\text { of Passaic } \\
\text { Cols } 2 \text { and } 3 \\
\text { Its from spec } \\
\text { sis at the } M \\
\text { added by } m \\
\text { int with those } \\
\text { the p-value }\end{array}$ & $\begin{array}{l}\text { Col } 1 \text { the act } \\
\text { cate Col } 1 \text { by s } \\
\text { ons where bot } \\
\text { vel. Cols } 5 \text { an } \\
\text { ture per estab } \\
\text { ructed exploit } \\
\text { test of overid } \\
0.05 ; \text { * p }<0.1 \text {. }\end{array}$ & $\begin{array}{l}\text { al number of immig } \\
\text { ling the actual and } \\
\text { the predicted and tt } \\
6 \text { include the inter } \\
\text { hment. Cols } 7 \text { and } \\
\mathrm{g} \text { World War I and } \\
\text { thifying restrictions. }\end{array}$ & $\begin{array}{l}\text { ants is scaled by } \\
\text { redicted numbe } \\
\text { e actual number } \\
\text { ction between } \\
\text { B estimate stack } \\
\text { ne quotas (equa } \\
\text { All regressions }\end{array}$ & $\begin{array}{l}\text { ictual population, } \\
\text { f immigrants by, } \\
\text { f immigrants are } \\
\text { ar dummies and, } \\
\text { Ifirst differences } \\
\text { ns (B1) and (B2) } \\
\text { ittial out city and }\end{array}$ \\
\hline
\end{tabular}

\section{Table D10. First Stage Trimming $1^{\text {st }}$ and $99^{\text {th }}$ Percentiles of Immigration}

\begin{tabular}{|c|c|c|c|c|c|c|c|c|}
\hline & \multicolumn{8}{|c|}{ Dep. Variable: Fraction of Immigrants } \\
\hline & $(1)$ & (2) & (3) & (4) & $(5)$ & $(6)$ & (7) & $(8)$ \\
\hline $\mathrm{Z}$ & $\begin{array}{c}0.889 * * * \\
(0.067)\end{array}$ & $\begin{array}{c}0.845^{* * * *} \\
(0.097)\end{array}$ & $\begin{array}{c}0.897 * * * \\
(0.079)\end{array}$ & $\begin{array}{c}0.945^{* * * *} \\
(0.105)\end{array}$ & $\begin{array}{c}0.758 * * * \\
(0.099)\end{array}$ & $\begin{array}{c}0.785^{* * * *} \\
(0.078)\end{array}$ & & \\
\hline$($ Z_WWI)*1920 & & & & & & & $\begin{array}{c}0.759 * * * \\
(0.162)\end{array}$ & $\begin{array}{c}0.790 * * * \\
(0.163)\end{array}$ \\
\hline (Z_Quotas)*1930 & & & & & & & $\begin{array}{c}0.787 * * \\
(0.347)\end{array}$ & $\begin{array}{c}1.209 * * * \\
(0.188)\end{array}$ \\
\hline$\left(Z_{-}\right.$WWI)*1930 & & & & & & & $\begin{array}{c}0.031 \\
(0.099)\end{array}$ & \\
\hline (Z_Quotas)*1920 & & & & & & & $\begin{array}{c}0.422 \\
(0.412)\end{array}$ & \\
\hline 1900 population & & $\mathrm{X}$ & & & & & & \\
\hline Predicted population & & & $\mathrm{X}$ & & & & & \\
\hline MSA analysis & & & & $\mathrm{X}$ & & & & \\
\hline Year by 1900 Log & & & & & $\begin{array}{l}\text { City and } \\
\text { imm pop }\end{array}$ & $\begin{array}{l}\text { Value added } \\
\text { manuf. }\end{array}$ & & \\
\hline WWI-Quotas IV & & & & & & & First Diff. & Long Diff. \\
\hline F-stat & 176.4 & 75.71 & 128.6 & 80.74 & 58.36 & 101.5 & 23.76 & 42.48 \\
\hline P-value Overid. Test & & & & & & & 0.456 & 0.557 \\
\hline Cities & 176 & 176 & 176 & 127 & 176 & 173 & 176 & 176 \\
\hline Observations & 528 & 528 & 528 & 379 & 528 & 519 & 352 & 176 \\
\hline
\end{tabular}




\section{Table D11. Main Results Omitting Potential Outliers}

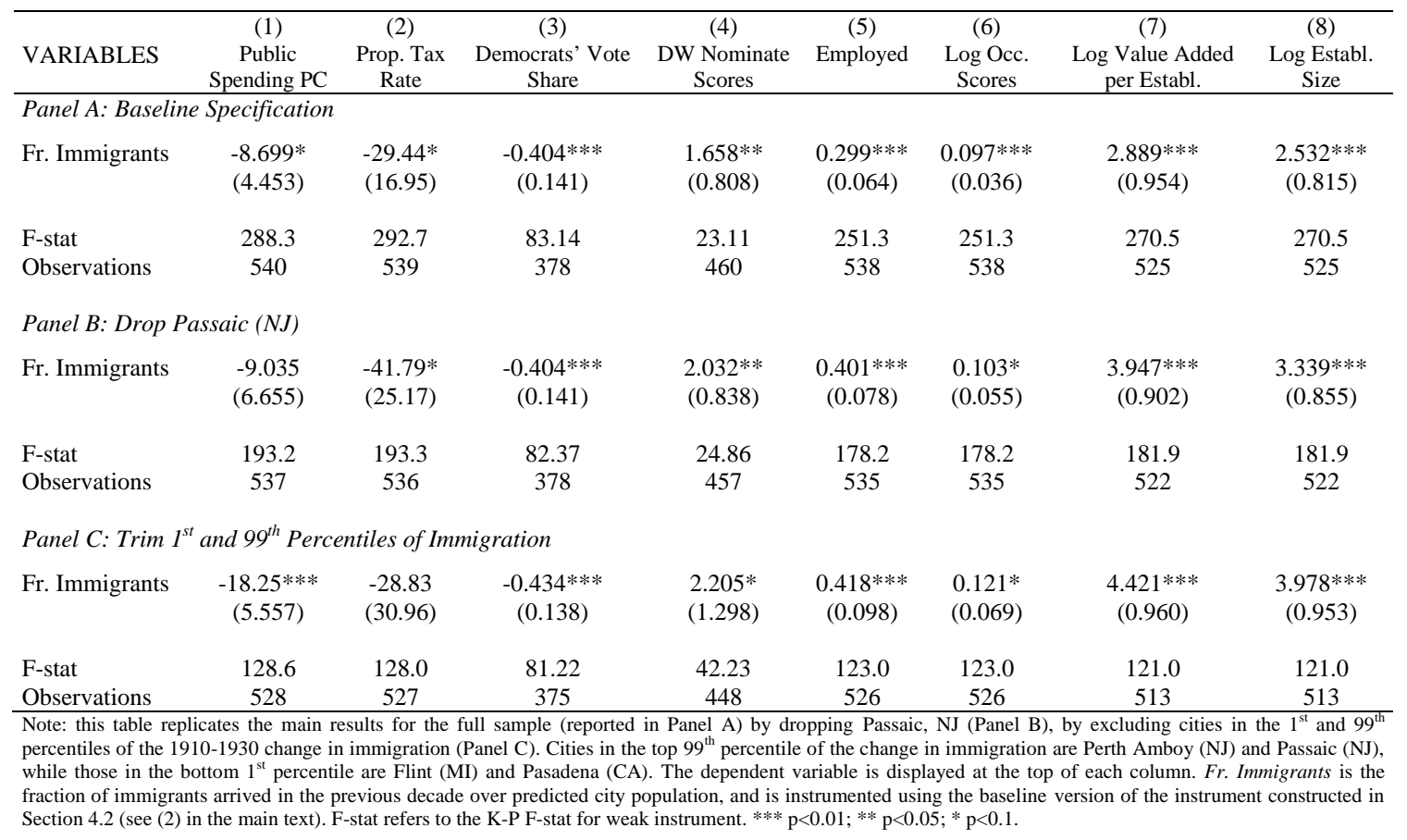

Table D12. Alternative Specifications/1

\begin{tabular}{|c|c|c|c|c|c|c|c|c|}
\hline VARIABLES & $\begin{array}{c}(1) \\
\text { Public } \\
\text { Spending PC }\end{array}$ & $\begin{array}{l}(2) \\
\text { Prop. Tax } \\
\text { Rate } \\
\end{array}$ & $\begin{array}{c}(3) \\
\text { Democrats' } \\
\text { Vote Share }\end{array}$ & $\begin{array}{c}(4) \\
\text { DW Nominate } \\
\text { Scores } \\
\end{array}$ & $\begin{array}{c}(5) \\
\text { Employed }\end{array}$ & $\begin{array}{c}(6) \\
\text { Log Occ. } \\
\text { Scores } \\
\end{array}$ & $\begin{array}{c}\text { (7) } \\
\text { Log Value Added } \\
\text { per Establ. }\end{array}$ & $\begin{array}{c}(8) \\
\text { Log Establ. } \\
\text { Size } \\
\end{array}$ \\
\hline \multicolumn{9}{|c|}{ Panel A. Baseline Specification } \\
\hline Fr. Immigrants & $\begin{array}{l}-8.699 * \\
(4.453)\end{array}$ & $\begin{array}{l}-29.44 * \\
(16.95)\end{array}$ & $\begin{array}{c}-0.404 * * * \\
(0.141)\end{array}$ & $\begin{array}{l}1.658 * * \\
(0.808)\end{array}$ & $\begin{array}{c}0.299 * * * \\
(0.064)\end{array}$ & $\begin{array}{c}0.097 * * * \\
(0.036)\end{array}$ & $\begin{array}{c}2.889 * * * \\
(0.954)\end{array}$ & $\begin{array}{c}2.532 * * * \\
(0.815)\end{array}$ \\
\hline F-stat & 288.3 & 288.3 & 83.14 & 23.11 & 251.3 & 251.3 & 270.5 & 270.5 \\
\hline \multicolumn{9}{|c|}{ Panel B. Immigrants Over 1900 Pop. } \\
\hline Fr. Immigrants & $\begin{array}{l}-5.794 * \\
(3.178)\end{array}$ & $\begin{array}{l}-16.09 \\
(11.56)\end{array}$ & $\begin{array}{c}-0.313 * * * \\
(0.112)\end{array}$ & $\begin{array}{c}1.174 * * \\
(0.559)\end{array}$ & $\begin{array}{c}0.213 * * * \\
(0.048)\end{array}$ & $\begin{array}{c}0.070 * * * \\
(0.026)\end{array}$ & $\begin{array}{c}2.105^{* * * *} \\
(0.730)\end{array}$ & $\begin{array}{c}1.726 * * * \\
(0.596)\end{array}$ \\
\hline F-stat & 226.7 & 230.4 & 55.42 & 70.30 & 175.3 & 175.3 & 198.2 & 198.2 \\
\hline \multicolumn{9}{|c|}{ Panel C. Immigrants Over Actual Pop. } \\
\hline Fr. Immigrants & $\begin{array}{c}-10.34 * * \\
(4.870)\end{array}$ & $\begin{array}{c}-35.06 * \\
(18.96)\end{array}$ & $\begin{array}{c}-0.387 * \\
(0.230)\end{array}$ & $\begin{array}{c}2.205 * * \\
(1.042)\end{array}$ & $\begin{array}{c}0.357 * * * \\
(0.056)\end{array}$ & $\begin{array}{c}0.116^{* * * *} \\
(0.040)\end{array}$ & $\begin{array}{c}3.456 * * * \\
(0.926)\end{array}$ & $\begin{array}{c}3.029 * * * \\
(0.810)\end{array}$ \\
\hline F-stat & 225.1 & 223.5 & 28.17 & 14.39 & 249.3 & 249.3 & 241.8 & 241.8 \\
\hline Observations & 540 & 539 & 378 & 460 & 538 & 538 & 525 & 525 \\
\hline
\end{tabular}




\section{Table D13. Alternative Specifications/2}

\begin{tabular}{|c|c|c|c|c|c|c|c|c|}
\hline VARIABLES & $\begin{array}{c}\text { (1) } \\
\text { Public } \\
\text { Spending PC }\end{array}$ & $\begin{array}{l}\text { (2) } \\
\text { Prop. Tax } \\
\text { Rate }\end{array}$ & $\begin{array}{c}\text { (3) } \\
\text { Democrats' Vote } \\
\text { Share }\end{array}$ & $\begin{array}{c}\text { (4) } \\
\text { DW Nominate } \\
\text { Scores }\end{array}$ & $\begin{array}{c}(5) \\
\text { Employed }\end{array}$ & $\begin{array}{c}(6) \\
\text { Log Occ. } \\
\text { Scores }\end{array}$ & $\begin{array}{c}\text { (7) } \\
\text { Log Value Added } \\
\text { per Establ. }\end{array}$ & $\begin{array}{c}\text { (8) } \\
\text { Log Establ. } \\
\text { Size }\end{array}$ \\
\hline \multicolumn{9}{|c|}{ Panel A: Immigrants' Stock } \\
\hline Fr. Immigrants & $\begin{array}{c}-9.843^{*} \\
(5.156)\end{array}$ & $\begin{array}{c}-33.29 * \\
(18.42)\end{array}$ & $\begin{array}{c}-0.489 * * * \\
(0.181)\end{array}$ & $\begin{array}{c}2.068 * * \\
(0.984)\end{array}$ & $\begin{array}{c}0.335 * * * \\
(0.071)\end{array}$ & $\begin{array}{c}0.109 * * * \\
(0.041)\end{array}$ & $\begin{array}{c}3.323 * * * \\
(1.047)\end{array}$ & $\begin{array}{c}2.911 * * * \\
(0.884)\end{array}$ \\
\hline F-stat & 81.14 & 80.90 & 19.49 & 37.88 & 81.20 & 81.20 & 76.66 & 76.66 \\
\hline \multicolumn{9}{|c|}{ Panel B: Immigrants from All Sources } \\
\hline Fr. Immigrants & $\begin{array}{c}-7.107 * * \\
(2.819)\end{array}$ & $\begin{array}{l}-17.78 \\
(11.67)\end{array}$ & $\begin{array}{c}-0.256 * * * \\
(0.075)\end{array}$ & $\begin{array}{c}0.907 * * \\
(0.462)\end{array}$ & $\begin{array}{c}0.189 * * * \\
(0.059)\end{array}$ & $\begin{array}{c}0.095 * * * \\
(0.027)\end{array}$ & $\begin{array}{c}1.945^{* * *} * \\
(0.627)\end{array}$ & $\begin{array}{c}1.605 * * \\
(0.634)\end{array}$ \\
\hline F-stat & 86.59 & 86.32 & 32.02 & 40.35 & 85.19 & 85.19 & 89.38 & 89.38 \\
\hline Observations & 540 & 539 & 378 & 460 & 538 & 538 & 525 & 525 \\
\hline $\begin{array}{l}\text { Note: Panel A rep } \\
\text { population, instrun } \\
\text { 1900. Panel B repl } \\
\text { during the previou } \\
\text { main text). The de }\end{array}$ & $\begin{array}{l}\text { es the baseline } \\
\text { ng it with both } \\
\text { s the baseline } \\
\text { ade over predi } \\
\text { ent variable is } r\end{array}$ & $\begin{array}{l}\text { pecification } \\
\text { rrent and las } \\
\text { ecification c } \\
\text { d city popul }\end{array}$ & $\begin{array}{l}\text { easuring immigrati } \\
\text { ed migration flows } \\
\text { sidering immigrant } \\
\text { ion, and is instrume }\end{array}$ & $\begin{array}{l}\text { (Fr. Immigran } \\
\text { teracted with th } \\
\text { from all sending } \\
\text { ted with the base }\end{array}$ & $\begin{array}{l}\text { as the frac } \\
\text { hare of imm } \\
\text { ountries: } F r \\
\text { e version of }\end{array}$ & $\begin{array}{l}\text { of all forei } \\
\text { nts (from ea } \\
\text { migrants ref } \\
\text { instrument }\end{array}$ & $\begin{array}{l}\text { born individuals ov } \\
\text { country of origin) liv } \\
\text { s to the fraction of in } \\
\text { nstructed in Section } \\
\text { * }<<0.01 ; * * p<0.05 ;\end{array}$ & $\begin{array}{l}\text { predicted city } \\
\text { g in the city in } \\
\text { higrants arrived } \\
2 \text { (see (2) in the } \\
\text { p }<0.1 .\end{array}$ \\
\hline
\end{tabular}

\section{Table D14. Relative vs Absolute Size of Immigrants}

\begin{tabular}{|c|c|c|c|c|c|c|c|c|}
\hline VARIABLES & $\begin{array}{c}\text { (1) } \\
\text { Public } \\
\text { Spending PC }\end{array}$ & $\begin{array}{l}\text { (2) } \\
\text { Prop. Tax } \\
\text { Rate }\end{array}$ & $\begin{array}{c}\text { (3) } \\
\text { Democrats' Vote } \\
\text { Share }\end{array}$ & $\begin{array}{c}\text { (4) } \\
\text { DW Nominate } \\
\text { Scores }\end{array}$ & $\begin{array}{c}(5) \\
\text { Employed }\end{array}$ & $\begin{array}{c}(6) \\
\text { Log Occ. } \\
\text { Scores }\end{array}$ & $\begin{array}{c}(7) \\
\text { Log Value Added } \\
\text { per Establ. }\end{array}$ & $\begin{array}{c}(8) \\
\text { Log Establ. } \\
\text { Size }\end{array}$ \\
\hline \multicolumn{9}{|c|}{ Panel A: Baseline Specification } \\
\hline Fr. Immigrants & $\begin{array}{c}-8.699 * \\
(4.453)\end{array}$ & $\begin{array}{c}-29.44 * \\
(16.95)\end{array}$ & $\begin{array}{c}-0.404 * * * \\
(0.141)\end{array}$ & $\begin{array}{c}1.658 * * \\
(0.808)\end{array}$ & $\begin{array}{c}0.299 * * * \\
(0.064)\end{array}$ & $\begin{array}{c}0.097 * * * \\
(0.036)\end{array}$ & $\begin{array}{c}2.889 * * * \\
(0.954)\end{array}$ & $\begin{array}{c}2.532 * * * \\
(0.815)\end{array}$ \\
\hline F-stat & 288.3 & 292.7 & 83.14 & 23.11 & 251.3 & 251.3 & 270.5 & 270.5 \\
\hline \multicolumn{9}{|c|}{ Panel B: Logs Specification } \\
\hline Log Immigrants & $\begin{array}{c}-4.348 * * * \\
(1.455)\end{array}$ & $\begin{array}{c}2.053 \\
(6.080)\end{array}$ & $\begin{array}{c}-0.066^{*} \\
(0.039)\end{array}$ & $\begin{array}{c}0.239 \\
(0.191)\end{array}$ & $\begin{array}{c}0.053 * * \\
(0.021)\end{array}$ & $\begin{array}{l}0.020 * \\
(0.012)\end{array}$ & $\begin{array}{c}1.082 * * * \\
(0.340)\end{array}$ & $\begin{array}{c}0.714 * * \\
(0.291)\end{array}$ \\
\hline F-stat & 247.9 & 251.3 & 83.75 & 42.17 & 19.08 & 19.08 & 15.20 & 15.20 \\
\hline
\end{tabular}


Table D15. Selection on Observables and Unobservables: Oster (2017)

\begin{tabular}{|c|c|c|c|}
\hline Specification: & $\begin{array}{l}\text { Baseline } \\
\text { (1) }\end{array}$ & $\begin{array}{l}\text { Controlled } \\
\text { (2) }\end{array}$ & $\begin{array}{l}\text { Bias Adjusted } \\
\text { Coefficient } \\
(3)\end{array}$ \\
\hline Public Spending per Capita & $\begin{array}{c}-8.688 * * \\
(4.333) \\
{[0.007]}\end{array}$ & $\begin{array}{c}-11.05 * * \\
(4.553) \\
{[0.120]}\end{array}$ & -11.87 \\
\hline Property Tax Rate & $\begin{array}{l}-29.42 * \\
(16.09) \\
{[0.012]}\end{array}$ & $\begin{array}{l}-21.71 \\
(19.12) \\
{[0.027]}\end{array}$ & -17.55 \\
\hline Democrats Vote Share & $\begin{array}{c}-0.383^{* *} \\
(0.147) \\
{[0.018]}\end{array}$ & $\begin{array}{l}-0.083 \\
(0.171) \\
{[0.179]}\end{array}$ & 0.017 \\
\hline DW Nominate Score & $\begin{array}{c}1.669 * * \\
(0.773) \\
{[0.019]}\end{array}$ & $\begin{array}{c}1.124 \\
(0.930) \\
{[0.061]}\end{array}$ & 0.892 \\
\hline Employment to Population & $\begin{array}{c}0.296 * * * \\
(0.054) \\
{[0.057]}\end{array}$ & $\begin{array}{c}0.234 * * * \\
(0.052) \\
{[0.166]}\end{array}$ & 0.206 \\
\hline Log Occupational Scores & $\begin{array}{c}0.096 * * * \\
(0.034) \\
{[0.014]}\end{array}$ & $\begin{array}{c}0.092 * * \\
(0.038) \\
{[0.028]}\end{array}$ & 0.090 \\
\hline $\begin{array}{l}\text { Log Value Added per } \\
\text { Establ. }\end{array}$ & $\begin{array}{c}2.859 * * * \\
(0.861) \\
{[0.046]}\end{array}$ & $\begin{array}{c}2.353^{* * *} * \\
(0.891) \\
{[0.094]}\end{array}$ & 2.056 \\
\hline Log Establ. Size & $\begin{array}{c}2.505 * * * \\
(0.737) \\
{[0.044]}\end{array}$ & $\begin{array}{l}1.996 * * \\
(0.845) \\
{[0.083]}\end{array}$ & 1.671 \\
\hline
\end{tabular}




\section{Table D16. Legislators' Ideology: Cross-Sectional Regressions}

\begin{tabular}{l} 
Dep. Variable: \\
\cline { 2 - 4 }
\end{tabular}

\section{Table D17. Presidential Elections: Alternative Definitions and Samples}

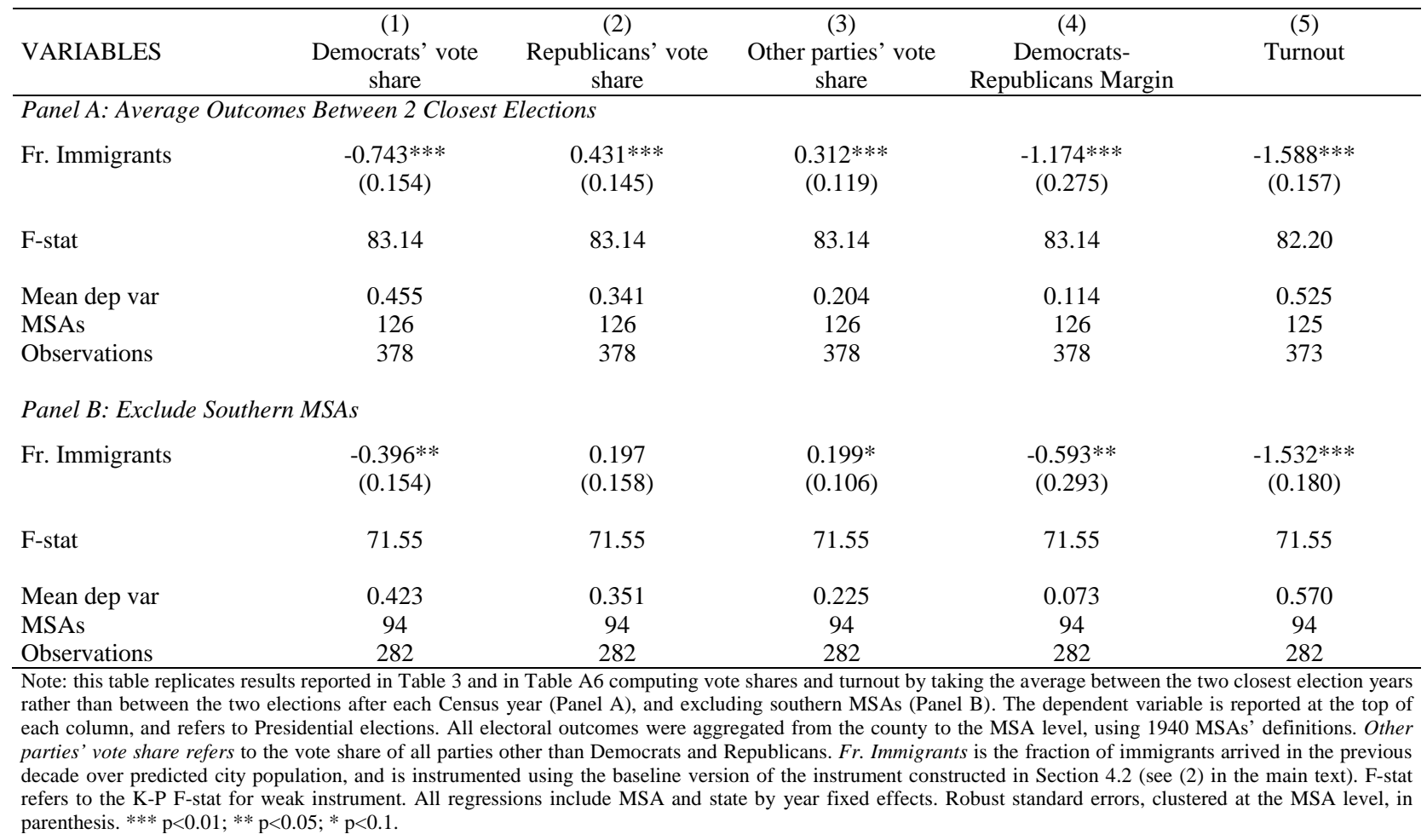




\section{Figure D1. Political Effects of Immigration, Interacting Year with $\alpha_{j c}$}

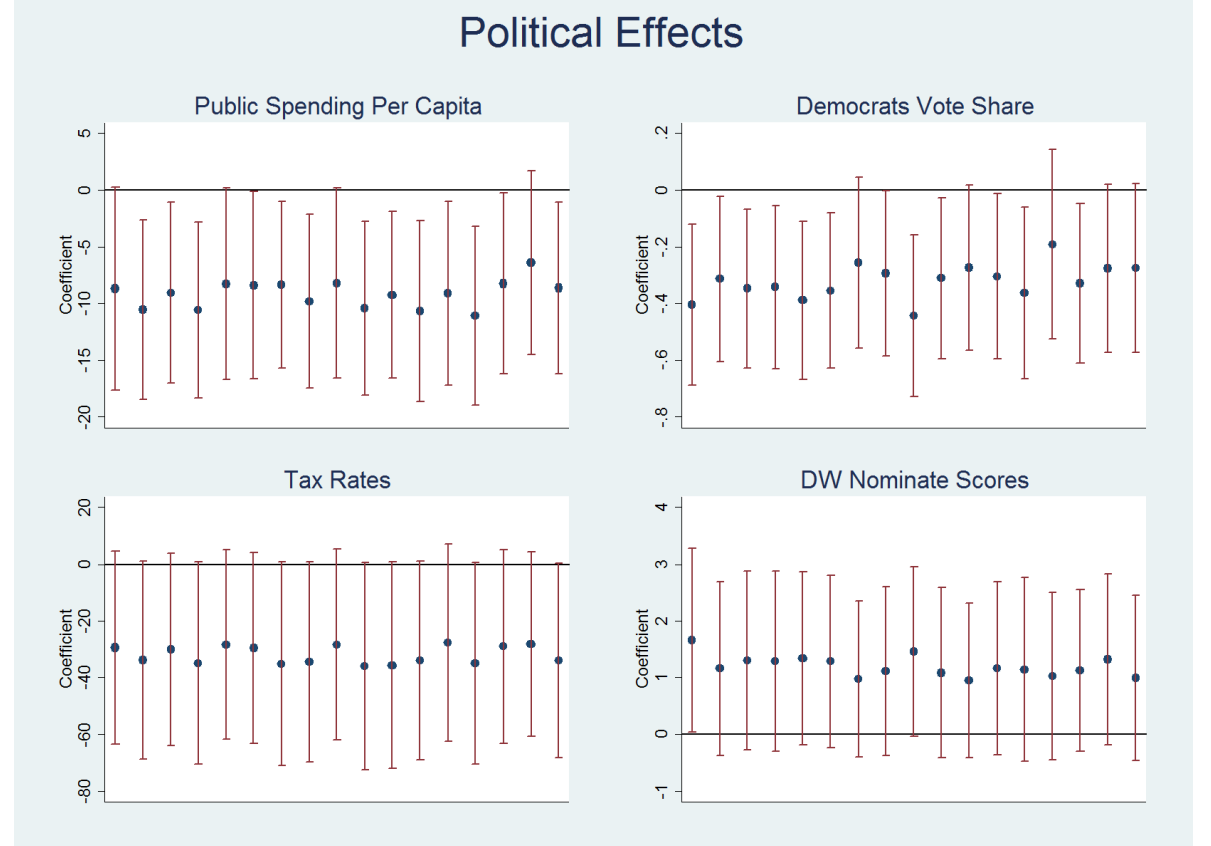

Note: the Figure plots the 2SLS point estimate (with corresponding 95\% confidence intervals) for the political effects of immigration augmenting the baseline specification reported in Table 3 with interactions between year dummies and the 1900 share of immigrants from each sending country.

Figure D2. Economic Effects of Immigration, Interacting Year with $\alpha_{j c}$

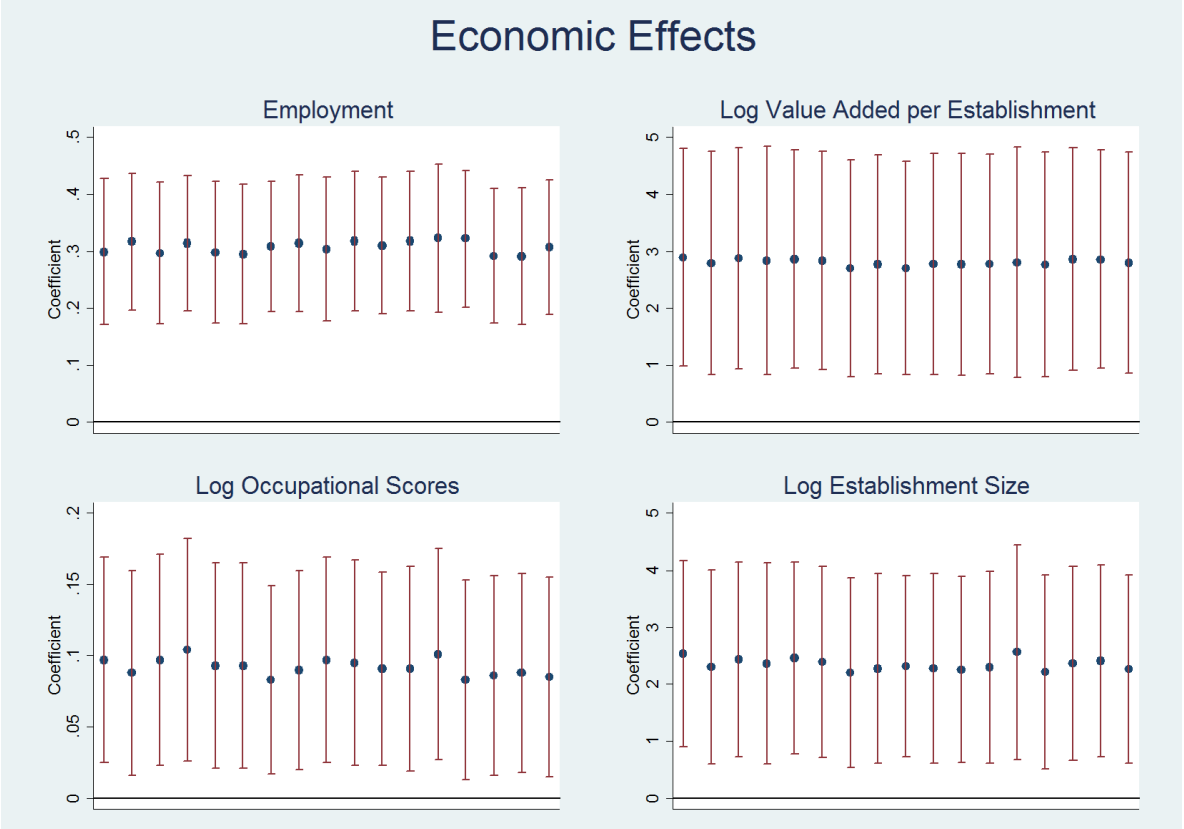

Note: the Figure plots the 2SLS point estimate (with corresponding 95\% confidence intervals) for the political effects of immigration augmenting the baseline specification reported in Table 5 with interactions between year dummies and the 1900 share of immigrants from each sending country. 


\section{Figure D3. Serial Correlation in National Migration Flows}

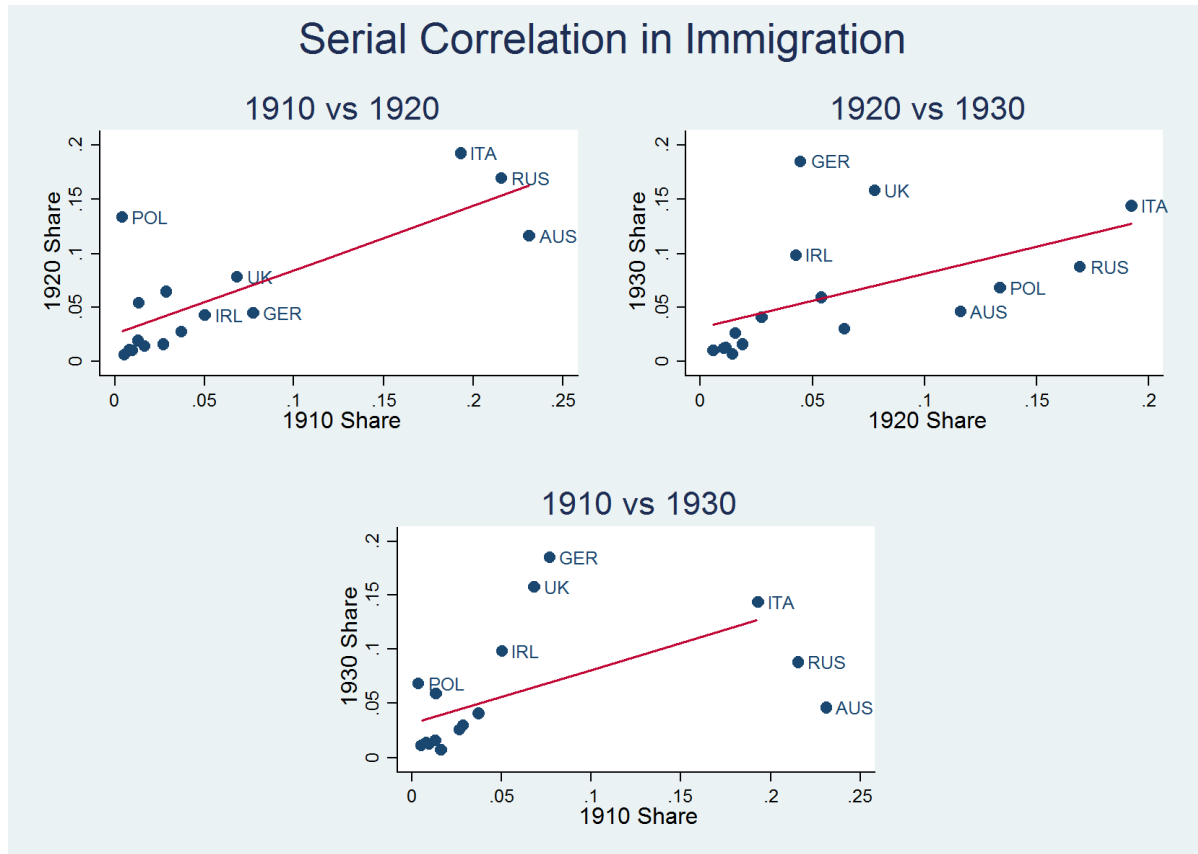

Note: each dot represents the correlation between the share of immigrants entering the US during decade $t$ and decade $t-10$ (or, t-20 in the graph at the bottom of the Figure). Shares are computed as the number of immigrants from each country relative to all European immigrants arriving in the US during the same period.

Figure D4. European Immigrants: Composition, 1910-1930



Note: the graph plots the share of European immigrants arrived in the previous decade from each region in the three decades, 1910, 1920, and 1930. Source: author's calculations using full count Census data (Ruggles et al., 2015). 


\section{Figure D5. First Stage Omitting Passaic (NJ)}

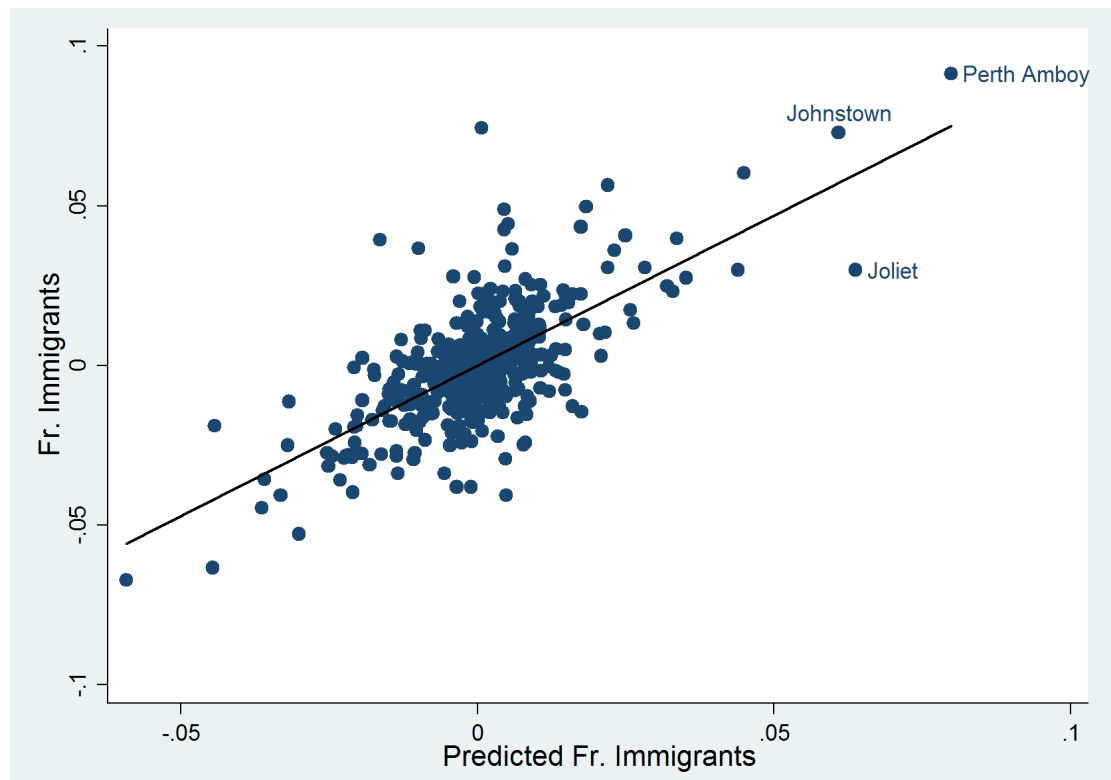

Note: this figure replicates Figure 4 in the main text omitting the city of Passaic (NJ). The y-axis (resp. $\mathrm{x}$-axis) reports the actual (resp. predicted) number of immigrants over predicted city population in each of the three Census years, 1910, 1920, and 1930. Each point in the scatter diagram represents the residual change in a city's actual and predicted fraction of immigrants after partialling out city and year by state fixed effects. The predicted number of immigrants is constructed as discussed in Section 4.2 in the text (see (2)). Predicted city population is obtained by multiplying 1900 city population with average urban growth, excluding that of the Census division where a city is located. The solid line shows the regression coefficient (coefficient $=0.940$, standard error $=0.068$ )

\section{Figure D6. Non-Parametric Regressions: Political Effects}

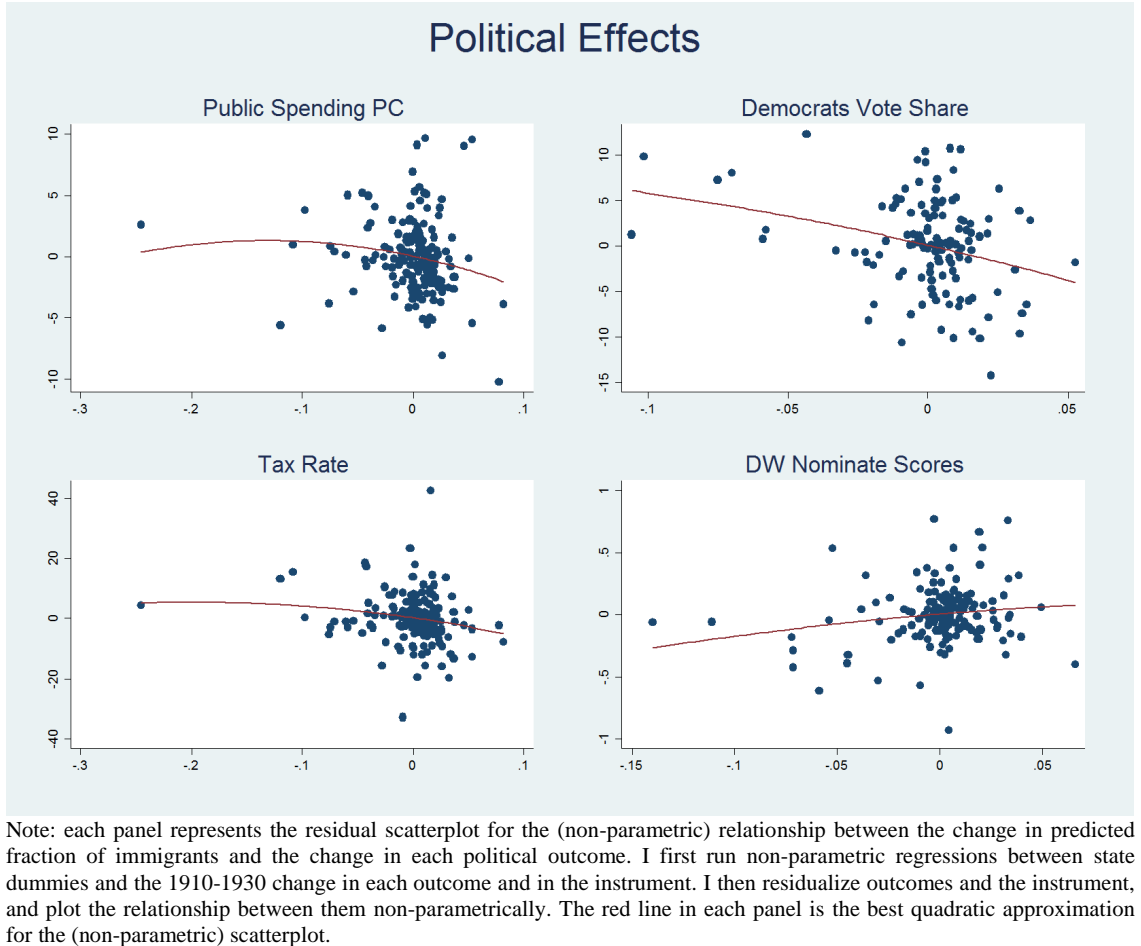




\section{Figure D7. Non-Parametric Regressions: Economic Effects}

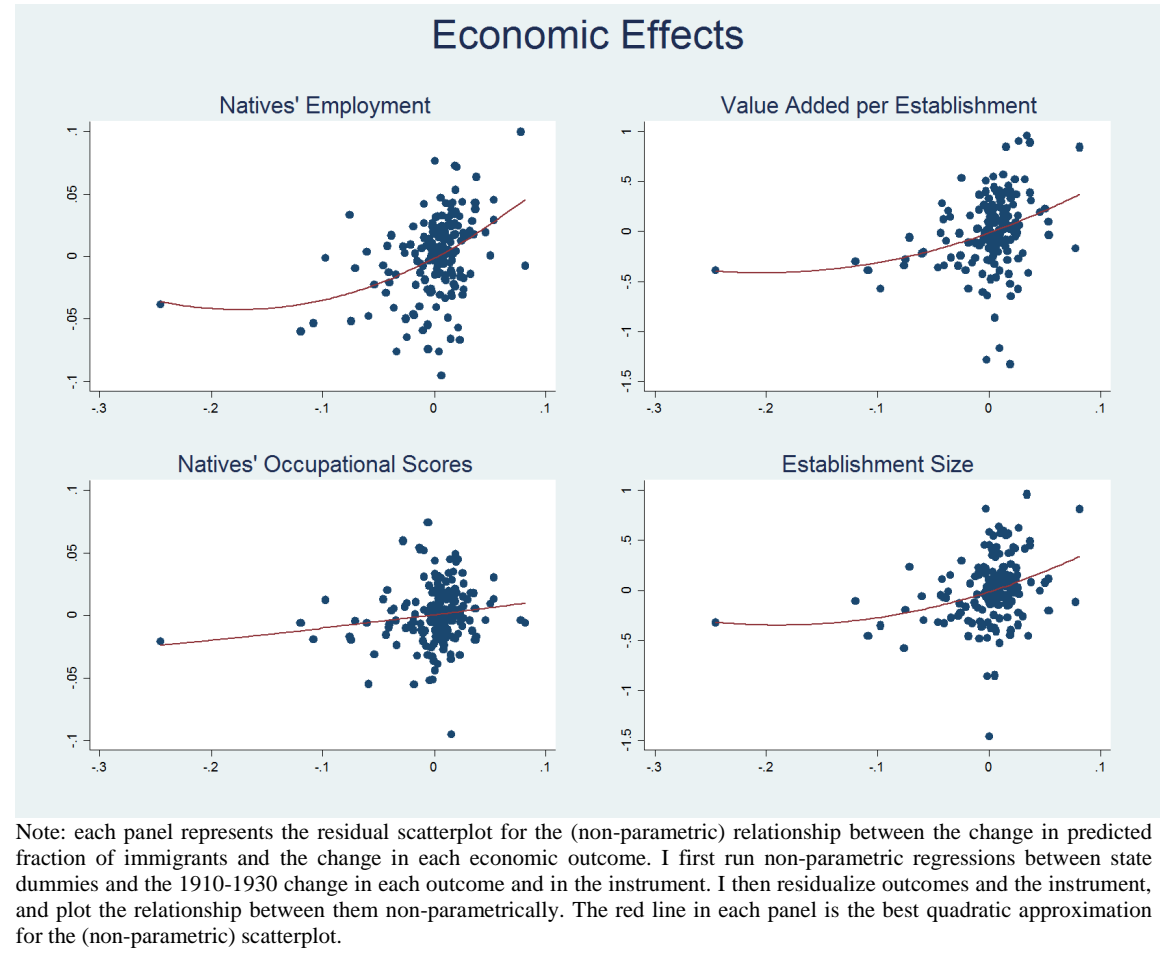

\section{Figure D8. Non-Parametric Regressions: Political Effects (Drop Passaic)}

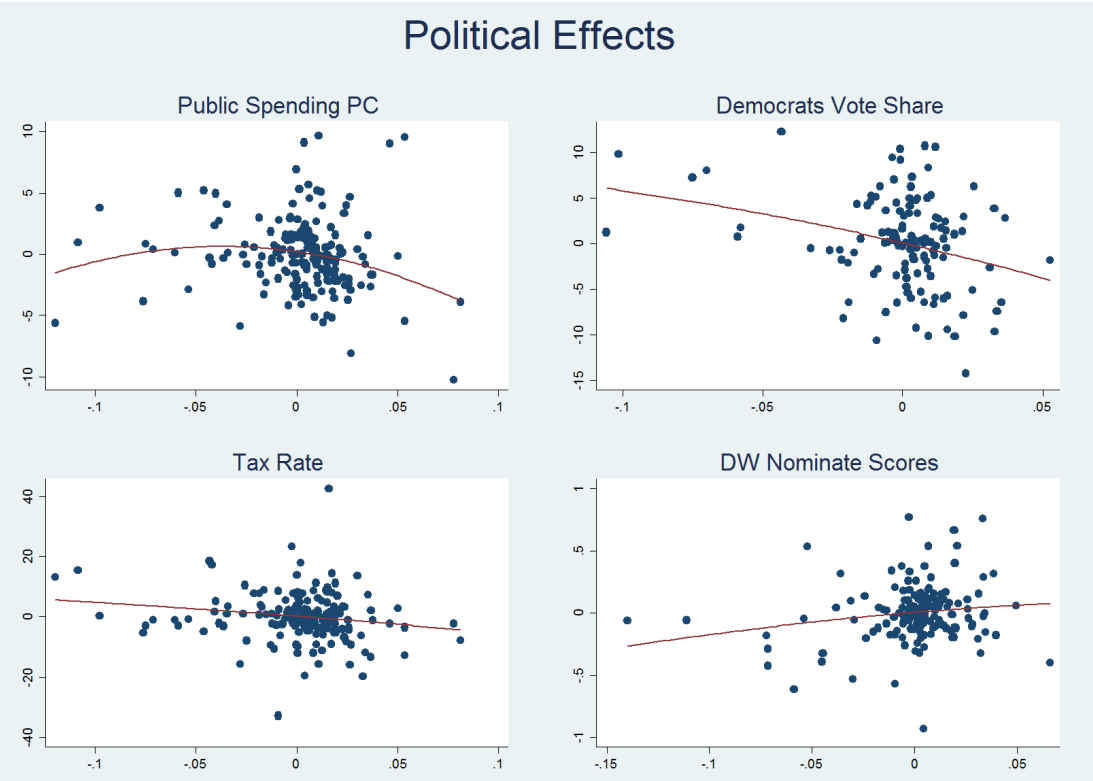

Note: This figure replicates Figure D6 dropping the city of Passaic (NJ). Specifically, each panel represents the residual scatterplot for the (non-parametric) relationship between the change in predicted fraction of immigrants and the change in each political outcome. I first run non-parametric regressions between state dummies and the 1910-1930 change in each outcome and in the instrument. I then residualize outcomes and the instrument, and plot the relationship between them nonparametrically. The red line in each panel is the best quadratic approximation for the (non-parametric) scatterplot. 


\section{Figure D9. Non-Parametric Regressions: Economic Effects (Drop Passaic)}

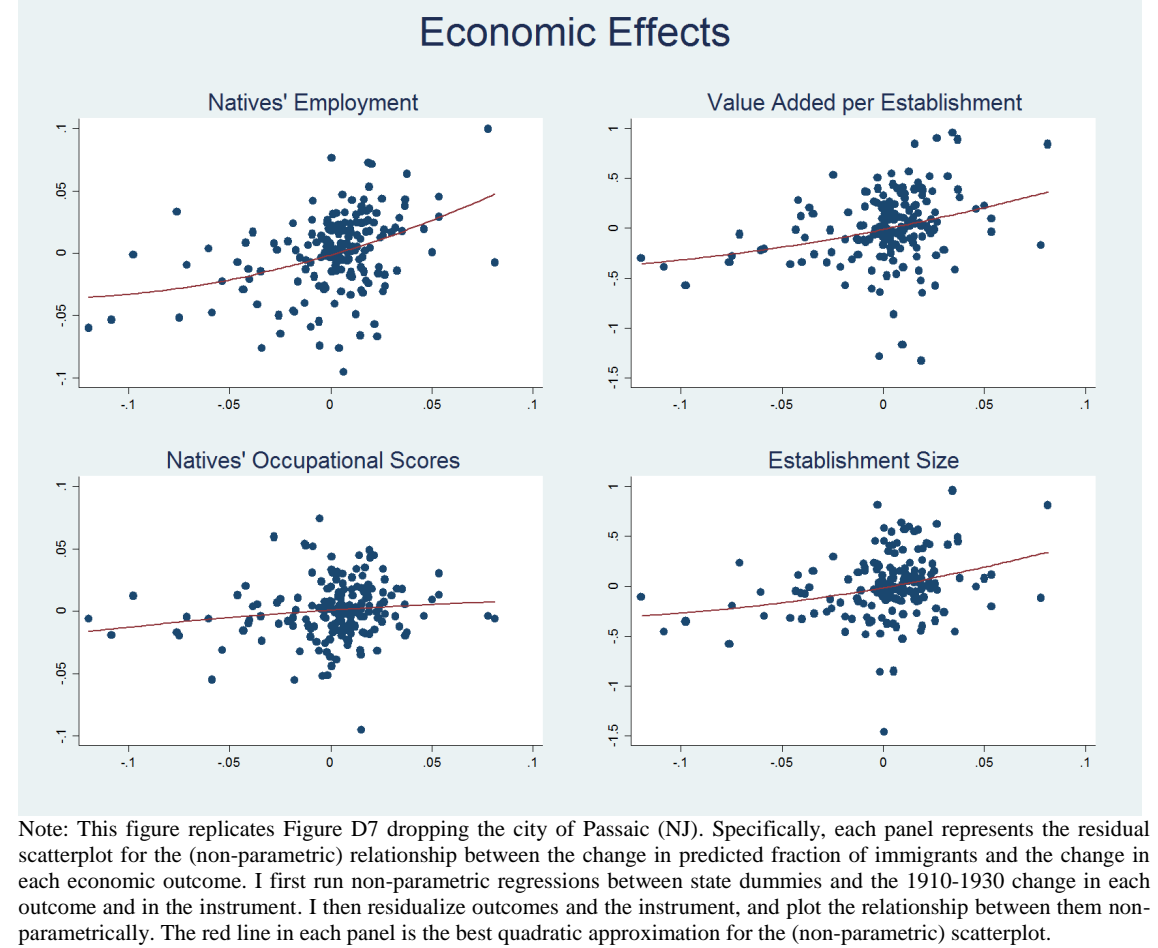




\section{E Additional Results}

In this section I present several additional results. First, I provide detailed evidence of immigrants-natives complementarities (Section E1). Second, I investigate which groups among natives likely benefitted from the new employment opportunities created by immigration (Section E2). Third, I study the effects of immigration on employment of previously arrived immigrants (Section E3). Fourth, I investigate the effects of immigration on the use of electricity in manufacturing (Section E4). Fifth, I test whether immigration had any effect on natives' rents (Section E5). Sixth, I explore possible heterogeneity in the effects of immigration, depending on city characteristics (Section E6). Seventh, I ask if Protestant and non-Protestant immigrants had differential economic effects (Section E7). Finally, I run a horse-race between religion and linguistic distance (Section E8), and study the effects of ethnic diversity on redistribution (Section E9).

\section{E1 Immigrants-Natives Complementarities}

A recent body of the literature has shown theoretically and empirically that immigrants can raise natives' wages and employment because of complementarity and gains from specialization (e.g. Peri and Sparber, 2009; Ottaviano and Peri, 2012; Foged and Peri, 2016). Building on these ideas, and exploiting the granularity of full count census data, I test whether this mechanism was at play also in the early twentieth century.

Table E1 studies the effects of immigration on the fraction of natives employed in specific occupations, which varied in their exposure to immigrants' competition. I proxy for the latter using the ratio of the probability that natives and immigrants held a given occupation in 1910, reported at the bottom of Table E1: values below (resp. above) 1 indicate that immigrants were over (resp. under) represented relative to natives (see also Table E2).

Columns 1 to 3 consider three occupations that were heavily exposed to immigrants' competition and required relatively low skills as well as language proficiency (manufacturing laborers, waiters, and blacksmiths). While the coefficient is statistically significant only in column 3, the point estimates are consistently negative, suggesting that natives responded to immigration by moving away from these occupations. In line with this interpretation, columns 4 to 6 document a significant increase in the fraction of natives employed in more skilled and less exposed occupations such as manufacturing foremen (column 4), electricians (column 5), and engineers (column 6). These findings can be effectively summarized using the words of Jewish-American economist and statistician Isaac Hourwich who, in 1912, noted that "the effect of immigration upon the occupational distribution of industrial wage earners has been the elevation of the English-speaking workmen to the status of an aristocracy of 
labor, while the immigrants have been employed to perform the rough work of all industries" (Meyer, 1981).

Among the occupations considered in Table E1, manufacturing foremen experienced the largest percent increase relative to the 1910 mean in response to immigration (Figure E1). This seems plausible for two reasons. First, becoming supervisors or floor managers did not require significant investment in education, and so even natives that were already in the labor force could be employed there relatively quickly. Second, as I show in the main text (Table 5, columns 3 and 4), immigration promoted the expansion of manufacturing, not only allowing to absorb the supply shock, but also creating new job opportunities for natives.

If immigration induced natives to specialize in more skilled occupations because of complementarity, this effect should be stronger when skill differences between immigrants and natives were larger. To investigate this conjecture, I classify immigrants as coming from linguistically close and far countries using the measure constructed by Chiswick and Miller (2005), which is based on the difficulty that Americans have in learning other languages. I define a country as linguistically far (resp. close) if its linguistic distance from English is above (resp. below) the median distance.

Relying on this admittedly crude measure of linguistic distance, in Table E3, I re-estimate equation (1) in the main text allowing immigrants from linguistically far and close countries to have differential effects on natives' employment and occupational standing. To ease comparisons across groups, I standardize both regressors by subtracting their means and dividing them by their standard deviations. In this way, coefficients in Table E3 can be interpreted as the effect of a one standard deviation change in the fraction of linguistically far and close immigrants respectively.

Consistent with Peri and Sparber (2009) and Foged and Peri (2016), while the employment effects of immigration are positive regardless of "immigrants' type", they are statistically significant only when immigrants came from linguistically far countries (columns 1 and 2). More importantly, there is evidence of natives' occupational upgrading (columns 3 and 4) only when immigrants were linguistically far from natives. Figure E2 plots the implied percent change in employment and occupational scores due to a one standard deviation change in immigrants from linguistically far (orange bar) and linguistically close (blue bar) countries. Similar patterns emerge when splitting immigrants between new (Russia, Eastern, and Southern Europe) and old (British Isles, Western Europe, Scandinavia, and Germany) source countries (see Panel B of Table E3), exploiting the fact that immigrants from new sending regions were more likely to be illiterate and unskilled (see Figures A1 and A2 above). ${ }^{21}$

\footnotetext{
${ }^{21}$ See also Biavaschi et al. (2017) and Greenwood and Ward (2015).
} 
Figure E3 further corroborates the idea that immigrants benefitted natives because of complementarities. Focusing on the fraction of immigrants arrived more than 10 years before (rather than on natives) in the same occupations considered in Figure E1, it shows that immigration did not favor occupational upgrading for previously arrived foreign born workers. This is in line with theoretical predictions (e.g. Borjas, 2003), since new immigrants were closer substitutes for previous migrants than for natives, and should have not benefitted from the inflow of "very similar" workers. $^{22}$

\section{E2 Natives' Employment Gains: Where Did They Come From?}

Table 5 in the paper shows that immigration increased natives' employment and occupational standing. My analysis suggests that two mechanisms were responsible for this pattern: first, immigration promoted firm growth and spurred industrialization; second, complementarities between immigrants and natives favored natives' occupational mobility. One remaining question, though, is: who were the newly employed natives? There are at least three possible, non-mutually exclusive, answers. First, immigration might have increased employment among previously unemployed natives. Second, the economic boom triggered by immigration, by increasing the opportunity cost of schooling, might have raised labor force participation of young native males who opted out of school. Third, by making cities economically more attractive, immigration may have favored internal migration of natives living elsewhere in the country. ${ }^{23}$

I start by investigating the first channel: if natives' employment gains accrued to previously unemployed workers, one would expect cities with a larger pool of unemployed individuals at baseline to experience higher employment growth in response to immigration. Table E4 tests this idea by interacting immigration with the 1910 unemployment rate, which is standardized to ease the interpretation of coefficients. ${ }^{24}$ As already documented in Table 5 (column 1), immigration had a positive and statistically significant effect on natives' employment. However, this effect was lower in cities with higher initial unemployment. Specifically, in a city where the 1910 unemployment rate was one standard deviation above the sample mean, the (positive) effect of immigration on natives' employment was $20 \%$ lower. ${ }^{25}$

\footnotetext{
${ }^{22}$ See online appendix E3 below for the effects of immigration on employment of previously arrived immigrants.

${ }^{23}$ Carlana and Tabellini (2018) show that immigration increased fertility among native couples. A fourth potential channel could thus be that natives' employment increased because of higher population growth, due to fertility and not internal migration. This seems unlikely, however, given that it would take at least 15 to 20 years for newly born individuals to enter the labor force.

${ }^{24}$ In Table E4, I consider the unemployment rate among men, irrespective of their nativity. However, results are unchanged when using the unemployment rate of native men.

${ }^{25}$ In column 3, I augment the baseline specification (presented in column 2) by interacting year dummies
} 
This finding suggests that natives' employment gains were unlikely to come from previously unemployed workers - if this were to be the case, one would expect the coefficient on the interaction term in Table E4 to be positive, rather than negative. In fact, consistent with the historical evidence reviewed in Section 2.2 of the paper, one interpretation of results in Table E4 is that immigration was economically beneficial because it allowed firms to overcome a persistent problem of labor scarcity. If previously unemployed workers did not represent the pool of natives responsible for the employment gains documented in the paper, it must be that either immigration favored internal migration or it pulled young natives into the labor force (and out of school), or both. In what follows, I provide evidence that both forces were at play.

First, in Table E5, I replicate results obtained in Carlana and Tabellini (2018), and show that immigration increased the probability of employment among native males in the age range 15-18 (Panel A). Symmetrically, the enrollment rate of the same age group fell significantly in response to immigration (Panel B), indicating that young natives dropped out of school to enter labor markets earlier in their life, because of the higher opportunity cost of schooling. ${ }^{26}$ As discussed in Carlana and Tabellini (2018), this pattern is consistent with findings for the more recent period in Cascio and Narayan (2015) and Charles et al. (2018) among others. Note, however, that this channel is very unlikely to account for the majority of the employment effects brought about by immigration. On the one hand, the supply of native males between 15 and 18 was relatively limited, and cannot, by any means, explain the large employment effects presented in Table 5. On the other, young natives likely entered at the bottom of the occupational ladder - something that cannot explain the positive effect of immigration on natives' occupational ranking. ${ }^{27}$

Second, I test if, by making cities relatively more attractive, immigrants promoted inmigration of natives from other parts of the country. Since prior to 1940 statistics on internal migration in the US do not exist, I proxy for the number of internal movers by looking at the fraction of (native) males in working age that were born outside the state of their city of residence (see also Bandiera et al., 2019). Table E6 documents that immigration had a positive and statistically significant effect on the fraction of internal movers (column 1). Reassuringly, the 1900 to 1910 change in the fraction of natives born in another state does not predict the (instrumented) change in immigration in subsequent decades (column 2).

Interestingly, 2SLS coefficients in column 1 of Tables 5 (0.299) and E6 (0.296) are quan-

with the 1900 immigrant and city population. Reassuringly, results are unchanged.

${ }^{26}$ As also noted in Carlana and Tabellini (2018), there were no systematic differences depending on teenagers' parentage.

${ }^{27}$ Consistent with this reasoning, Carlana and Tabellini (2018) show that the positive effects of immigration on employment were strongest among native men between the age of 20 and 35 . 
titatively very close to each other, suggesting that internal migration likely represented the main mechanism behind the rise in natives' employment. One may wonder why firms did not create jobs for natives in the first place, or why native workers were not willing to move to urban areas even before the inflow of international immigrants. One answer, consistent with the historical evidence discussed in Section 2.2, is that immigration raised the supply of cheap labor and allowed firms to expand. As firms expanded, because of complementarity between the skills of immigrants and those of natives (Peri and Sparber, 2009), new, relatively more skilled jobs were created for native workers. ${ }^{28}$ This interpretation squares well with the positive effect of immigration on natives' occupational scores (Table 5, column 2), and suggests that internal migrants were positively selected.

If immigration fostered in-migration of natives, it must be that some areas in the US lost population, possibly also experiencing economic losses. Section D2 reassuringly documents that immigration was unlikely to generate negative spillovers across the cities in my sample (see Table D5). This is important because it suggests that endogenous population responses are unlikely to introduce systematic (upwards) bias in my estimates for the economic effects of immigration. One possibility, consistent with findings in the recent working paper by Abramitzky et al. (2019), is that rural areas were negatively affected by immigration to cities, as workers and economic resources moved away from the periphery (i.e. the countryside) and into the core of local economies (i.e. cities). Investigating this idea goes beyond the scope of this paper. However, it is important to emphasize that none of the results in my work would be affected by the presence of rural-urban reallocation, since non-urban areas are not included in my sample (and thus do not serve as a "control group").

\section{E3 Effects of Immigration on Previous Immigrants' Employment}

In this section, I investigate the effects of immigration on employment of previously arrived immigrants. Relative to natives, new and old immigrants have relatively similar skills, and should thus be closer substitutes in production. Because of this, it would be surprising if immigration had a positive effect also on employment of previous migrants. Reassuringly, Figure E4 shows that this was not the case. In particular, here I plot the coefficient (and corresponding $95 \%$ confidence intervals) for the effect of immigration on employment of different groups of immigrants. ${ }^{29}$

Starting from the left, the first dot reports the coefficient for the effect of immigration

\footnotetext{
${ }^{28}$ In online appendix F, I show that a model of directed technological change with complementarities between natives and immigrants can explain the empirical results obtained in my paper.

${ }^{29}$ Since the dependent variable in this analysis refers to the foreign born, I re-estimate a version of equation (1) in the paper by also including the interaction between year dummies and the 1900 fraction of immigrants.
} 
on natives' employment (which is positive and statistically significant). Next, moving from the left to the right of the figure on the x-axis, there is no positive effect of immigration on employment of immigrants from either Southern and Eastern (second group from the left) or Northern and Western (third group from the left) Europe. In fact, the coefficient is negative, although not statistically significant. Consistent with the idea that European immigrants gradually assimilated over time (Abramitzky and Boustan, 2017; Abramitzky et al., 2018), the point estimate is negative for relatively recent immigrants (i.e. those arrived between 10 and 20 years before), while it is zero for foreign born that had spent at least 20 years in the United States. In addition to providing a useful placebo check for the validity of the empirical strategy, Figure E4 also suggests that natives' backlash was unlikely to emerge because immigrants were able to upgrade faster than natives in this period (see the discussion in Section 6.3 of the paper).

\section{E4 Immigration and Electricity in Manufacturing}

One possible explanation for the positive effect of immigration on firms' productivity is that the inflow of immigrants encouraged the adoption of new technologies that made intensive use of electricity, e.g. the assembly line, in turn raising the demand for managers and supervisors, and for high skilled workers such as electricians (Goldin and Katz, 2009; Katz and Margo, 2014). Lack of systematic data on electricity use at the city level before 1940 prevents me from investigating this idea directly. However, I digitized data on the share of horsepower coming from electricity reported in the 1929 Census of Manufactures for selected US counties. Aggregating the data to the MSA level, and running cross-sectional regressions, I find that MSAs that received more immigrants between 1910 and 1930 had a larger share of power coming from electricity in 1930 (Table E7). Because of the cross-sectional nature of this exercise, the evidence in Table E7 should be interpreted as only suggestive. ${ }^{30}$ Nevertheless, it is consistent with the idea that immigration may have induced a faster adoption of electricity and of related technologies.

\section{E5 Immigration and Natives' Rents}

To directly assess the causal effect of immigration on rents, ideally, one would want to exploit data that vary both over time and across neighborhoods within the same city. Unfortunately, such data are not consistently available for the historical period studied in my paper.

\footnotetext{
${ }^{30}$ All regressions control for state fixed effects. Columns 2 and 4 also include a number of 1900 controls such as city and immigrants population, skill ratios, and measures of industrial production.
} 
Instead, to indirectly investigate the possibility that higher rents fueled natives' discontent, in Figure E5, I plot the relationship between the 1910 to 1930 instrumented change in immigration (x-axis) and 1930 natives' average rents (y-axis), after partialling out state fixed effects. ${ }^{31}$ Because of the cross-sectional nature of this regression, results in Figure E5 should be interpreted with some caution, but they suggest that immigration was not correlated with rents paid by natives. This, in turn, weighs against the possibility that natives' backlash was triggered (mainly) by higher rents. As discussed in the main text of the paper, one potential explanation for why, despite its positive effect on productivity, immigration did not increase rents is that immigrants represented a production amenity, but were perceived as a consumption disamenity, as documented for the contemporaneous period by a number of papers in both Europe and the US (e.g. Card et al., 2012; Saiz and Wachter, 2011).

\section{E6 Heterogeneous Effects of Immigration}

\section{E6.1 City Size and Population Density}

In the paper, I argue that natives' backlash was due predominantly to cultural differences between immigrants and natives. However, an alternative interpretation is that, in spite of the positive economic effects, immigration created congestions and lowered living standards in already crowded cities. In Table E8, I explore this possibility by testing if immigration had heterogeneous effects depending on baseline city population (Panel A) and population density (Panel B). To ease the interpretation of 2SLS coefficients, both variables are standardized by subtracting their mean and dividing through their standard deviation. Population density was constructed dividing city population by land area, which was collected and digitized from the Financial Statistics of Cities. ${ }^{32}$

Starting from city population, Panel A documents that immigration lead to smaller reductions in public spending per capita or property tax rates (columns 1 and 2) in larger cities, but the increase in DW Nominate scores (column 4) was larger in more populated places. These patterns suggest that the relationship between political backlash and city size was mixed. Consistent with the presence of agglomeration economies, larger cities experienced a stronger industrial growth following immigration (columns 7 and 8), although here the employment gains were marginally lower. Next, when focusing on population density (Panel B) - probably the most accurate variable to capture congestion costs - there is some evidence that immigration lead to larger tax and spending cuts in more densely populated

\footnotetext{
${ }^{31} 1930$ is the first year in which data on rents were collected by the US Census.

${ }^{32}$ Since neither population density nor land area is available for MSAs and city-Congressional District units, I computed density by taking the weighted average across the cities belonging to the MSA or the Congressional District.
} 
cities, but had no differential effect on either the Democrats' vote share (column 3) or DW Nominate scores (column 4). ${ }^{33}$

Overall, the unstable patterns documented in Table E8 are not consistent with congestion costs being the main channel behind the political effects of immigration, although one cannot rule out the possibility that they played a role in fostering natives' grievances against immigrants.

\section{E6.2 Average Length of Stay of Immigrants}

Both historical and anecdotal evidence suggests that, until the early 1900s, immigrants represented an important political group in major US cities (e.g. Kleppner, 1982; Goldin, 1994; Shertzer, 2016). Hence, it might be interesting to explore if political reactions were mediated by the presence of more established immigrants. Ex-ante, the effects of a larger share of more established (and likely more assimilated) immigrants on city politics and, in particular, on natives' backlash is ambiguous. On the one hand, backlash can be decreasing in the time spent by previous immigrants in the US, if natives begin to consider the latter as part of the in-group of the society, and if established and new migrants belong to the same ethnic group. On the other hand, if new migrants belong to a different ethnic group than that of more established ones, due to "status" (or, housing and labor market) competition, old immigrants might join natives in their anti (new) immigrant positions (Goldin, 1994).

In Table E9, I test empirically these ideas by interacting the main effect of immigration with a dummy equal to 1 for cities where the average immigrants' length of stay at baseline was above the sample median (18 years). Except for the Democrats' vote share (column 3), the average length of stay in the US does not affect natives' political reactions in a statistically significant way. If anything, immigration seems to lead to higher political opposition in cities where the average length of stay of previous immigrants was higher, although standard errors are very large. ${ }^{34}$

Instead, the opposite holds for Presidential elections: in this case, the negative effect of immigration on the Democrats' vote share is entirely driven by cities where the average length of stay of previous immigrants was below the sample median. One interpretation for this finding, strongly consistent with Shertzer (2016), is that in cities with more assimilated ethnic enclaves, new immigrants were more effectively mobilized to express their (pro-immigration) preferences. Finally, as expected, there is no significantly different eco-

\footnotetext{
${ }^{33}$ Except for occupational scores (column 6), which increased more in more densely populated places, immigration did not have a statistically different effect on economic outcomes in more vs less densely populated cities.

${ }^{34}$ This interpretation would be consisent with Goldin (1994).
} 
nomic effect of immigration depending on immigrants' length of stay at baseline (columns 5 to 8$)$.

\section{E7 Religion and the Economic Effects of Immigration}

Table 6 in the paper shows that political discontent emerged entirely when immigrants came from Catholic or Jewish, but not from Protestant, countries. My interpretation is that this was due to cultural differences between immigrants and natives, which were significantly more pronounced for Catholics and Jews (e.g. Higham, 1955). However, an alternative interpretation is that non-Protestant immigrants had a negative (or, a less positive) economic effect on natives. To rule out this possibility, in Figures E6 and E7, I plot the effect of Protestant and non-Protestant immigration on, respectively, natives' employment and log of value added by manufacturing per establishment. To ease the interpretation of results, as in Table 6, I standardize the inflow of immigrants for each religious group by subtracting the mean and dividing through the standard deviation.

Immigrants from the two religious groups did not have a statistically different impact on either natives' labor market outcomes or economic activity. In the full sample, nonProtestant immigration has a somewhat lower effect on natives' employment (left panel in Figure E6). However, once the city of Passaic (NJ) is excluded, the effects of immigration from Protestant and non-Protestant countries on natives' employment become almost identical (right hand side panel in Figure E6).

These results suggest that political backlash triggered by non-Protestant immigration did not come from a differential effect that these immigrants had on natives' labor market outcomes, and provide further support for the cultural hypothesis advanced in the paper. Importantly, as for Tables 6 and 7, results in Figures E6 and E7 are robust to controlling simultaneously for an index of average literacy of the foreign born - this is an important control, since one may be worried that Protestant immigrants were more skilled and better educated than non-Protestant ones (although, the Jews are a clear counterexample to this possibility).

\section{E8 A Horse-Race Between Religion and Linguistic Distance}

Tables 6 and 7 in the paper document that political discontent: $i$ ) took place only when immigrants came from non-Protestant countries; and $i i)$ was increasing in the linguistic distance between immigrants and natives. In this section, I investigate if either of the two measures of cultural diversity dominates over the other by replicating the analysis in Table 7 including simultaneously religion and linguistic distance. To ease the interpretation of 
results, the fraction of immigrants from Protestant and non-Protestant countries are both standardized by subtracting their mean and dividing through their standard deviation. Thus, as for the index of linguistic distance, the coefficient on immigration from each religious group should be interpreted as the effect of a one standard deviation increase in the fraction of immigrants from Protestant and non-Protestant countries.

2SLS results are reported in Table E10. When focusing on taxes and spending (columns 1 to 4), only the index of linguistic distance is statistically significant. Instead, even if the coefficient on immigration from non-Protestant countries is negative, it is quantitatively small and imprecisely estimated. However, for electoral outcomes (columns 5 to 8 ), the opposite pattern emerges: only immigration from non-Protestant countries is associated with a significant reduction (resp. increase) in support for Democrats (resp. in legislators' ideology and support for the 1924 Immigration Act). ${ }^{35}$ One possible interpretation is that the salience of different cultural attributes might differ across political issues.

\section{E9 Ethnic Diversity}

A large literature has shown that ethnic diversity is associated with lower public goods provision and with more limited redistribution (e.g. Alesina et al., 1999; Beach and Jones, 2017; Luttmer, 2001). The argument advanced in these works is that both altruism and the utility from public goods' consumption are lower when they involve inter-ethnic interactions. It follows that, if immigration reduced natives' demand for public goods by increasing ethnic diversity, this effect should be stronger when the ethnic composition of foreign born was more heterogeneous. Also, a more diverse foreign born population may reduce immigrants' ability to act as a unified political group, in turn reinforcing the effectiveness of natives' actions. ${ }^{36}$ To test these conjectures, I interact immigration, $I m m_{c s t}$, with an index of ethnic diversity (Alesina et al., 1999) of the foreign born population, $E D_{c s t}=1-\sum_{j}\left(s h_{c s t}^{j}\right)^{2}$, where $s h_{c s t}^{j}$ is the share of ethnic group $j$ among the foreign born population introduced in the previous section. I then estimate

$$
y_{c s t}=\gamma_{c}+\delta_{s t}+\beta_{1} I m m_{c s t}+\beta_{2} I m m_{c s t} * E D_{c s t}+\beta_{3} E D_{c s t}+u_{c s t}
$$

As in the main text (Section 7.2), to ease the interpretation of results, which are reported in Table E11, I standardize $E D_{\text {cst }}$ by subtracting its mean and dividing it by its standard deviation. The coefficient on the interaction between immigration and ethnic diversity, $\beta_{2}$,

\footnotetext{
${ }^{35}$ Somewhat surprisingly, the index of linguistic distance seems to have a positive effect on the support for Democrats (column 5).

${ }^{36}$ An alternative view is discussed in Borjas (2016), who suggests that higher diversity could make immigration less salient, in turn reducing natives' backlash.
} 
can thus be interpreted as the additional effect of immigration for a city with ethnic diversity one standard deviation above the sample mean. When estimating $(E 1)$, the interaction term, $I m m_{c s t} * E D_{c s t}$, is instrumented with the interaction between $E D_{c s t}$ and predicted immigration, i.e. $Z_{c s t}$ in equation (2) in the main text.

The (negative) effect of immigration on tax revenues per capita is larger when ethnic diversity among foreign born is higher (columns 1 and 2). Somewhat surprisingly, though, when looking at tax rates (column 3), the coefficient on the interaction between immigration and ethnic diversity is not statistically significant, even if it is negative. Next, in line with columns 1 and 2, column 4 shows that the effects of immigration on public spending are larger (i.e. more negative) when ethnic diversity is higher. This result is consistent with the existing literature (e.g. Alesina et al., 1999), and corroborates the interpretation advanced in Section 5 that immigrants lowered natives' utility from consumption of public goods by increasing ethnic diversity. 


\section{Table E1. Immigration and Natives' Occupational Upgrading}

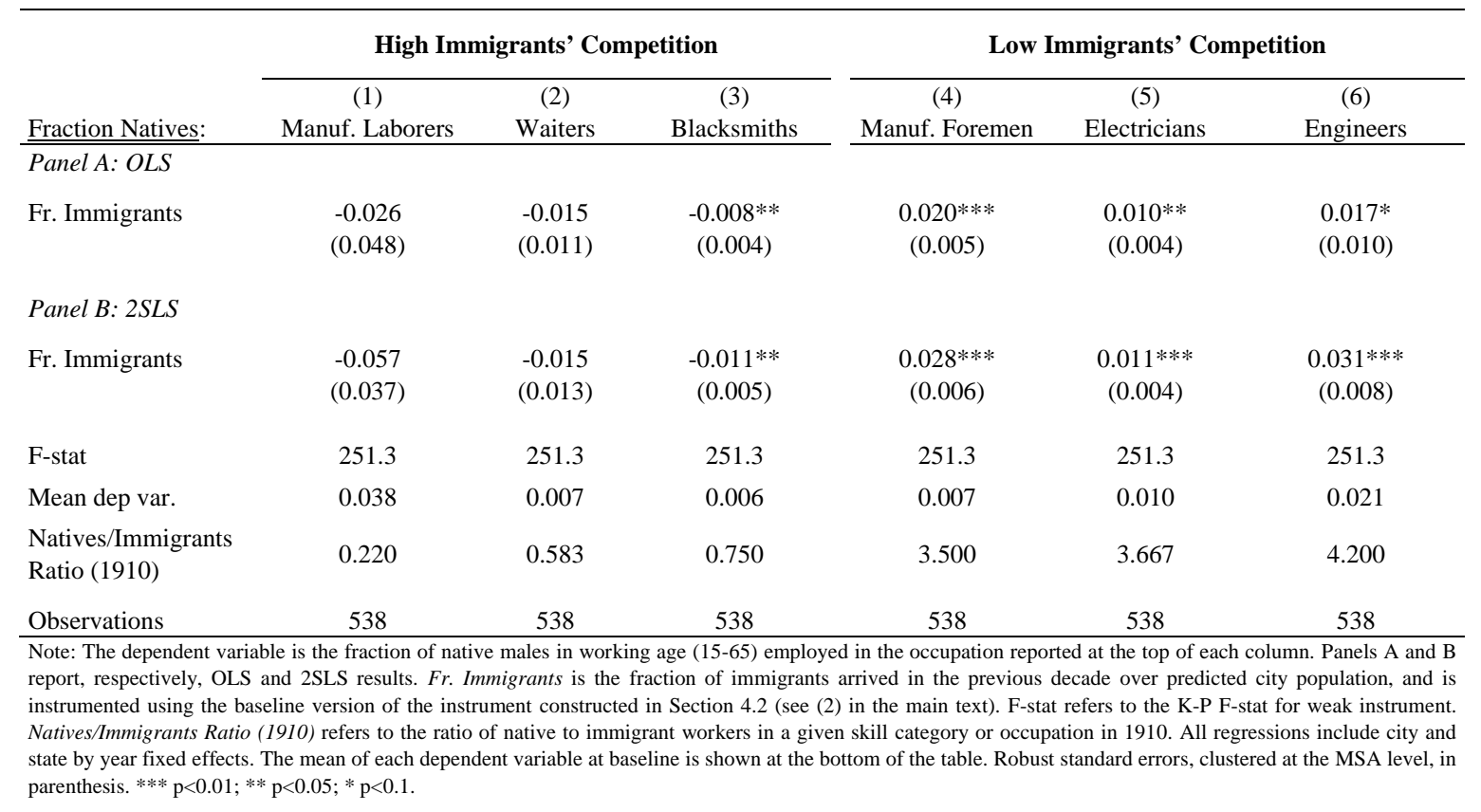

\section{Table E2. Labor Market Characteristics of Immigrants and Natives}

\begin{tabular}{|c|c|c|c|}
\hline & Natives & Immigrants & Ratio (Natives to Immigrants) \\
\hline \multicolumn{4}{|l|}{ Panel A: Industries } \\
\hline Manufacturing & 0.216 & 0.437 & 0.494 \\
\hline Construction & 0.089 & 0.107 & 0.832 \\
\hline Trade & 0.182 & 0.169 & 1.077 \\
\hline Services (excluding personal) & 0.098 & 0.037 & 2.649 \\
\hline Public Sector & 0.034 & 0.005 & 6.800 \\
\hline \multicolumn{4}{|c|}{ Panel B: Skills and Broad Occupational Groups } \\
\hline High Skilled & 0.345 & 0.126 & 2.738 \\
\hline Unskilled & 0.347 & 0.614 & 0.565 \\
\hline Clerical and Sales & 0.198 & 0.065 & 3.046 \\
\hline Laborers & 0.110 & 0.311 & 0.354 \\
\hline \multicolumn{4}{|c|}{ Panel C: Narrowly Defined Occupations } \\
\hline Manuf. Laborers & 0.038 & 0.150 & 0.253 \\
\hline Waiters & 0.007 & 0.012 & 0.583 \\
\hline Blacksmiths & 0.006 & 0.008 & 0.750 \\
\hline Manuf. Supervisors & 0.007 & 0.002 & 3.500 \\
\hline Electricians & 0.010 & 0.003 & 3.667 \\
\hline Engineers & 0.021 & 0.005 & 4.200 \\
\hline
\end{tabular}




\section{Table E3. Immigrants' Characteristics and Natives' Employment}

\begin{tabular}{l} 
Dependent Variable: \\
\cline { 2 - 4 } \\
\cline { 2 - 3 }
\end{tabular}

\section{Table E4. Immigration, Natives' Employment, and Labor Scarcity}

\begin{tabular}{l}
\hline \\
\hline
\end{tabular}




\section{Table E5. Enrollment, and Labor Force Participation of Young Natives}

\begin{tabular}{|c|c|c|c|c|}
\hline & $(1)$ & (2) & (3) & (4) \\
\hline & \multicolumn{4}{|c|}{ Panel A. Employment to Population Ratio, Native Males (15-18) } \\
\hline Fr. Immigrants & $\begin{array}{c}0.307 * * * \\
(0.103)\end{array}$ & $\begin{array}{c}0.312 * * * \\
(0.105)\end{array}$ & $\begin{array}{l}0.150^{*} \\
(0.084)\end{array}$ & $\begin{array}{c}0.261 * * \\
(0.116)\end{array}$ \\
\hline \multirow[t]{2}{*}{ Mean Dep. Variable } & 0.602 & 0.595 & 0.547 & 0.633 \\
\hline & \multicolumn{4}{|c|}{ Panel B. Share Enrolled in School, Native Males (15-18) } \\
\hline Fr. Immigrants & $\begin{array}{c}-0.131 * * \\
(0.065)\end{array}$ & $\begin{array}{c}-0.139 * * \\
(0.070)\end{array}$ & $\begin{array}{l}-0.081 \\
(0.072)\end{array}$ & $\begin{array}{l}-0.042 \\
(0.073)\end{array}$ \\
\hline Mean Dep. Variable & 0.323 & 0.338 & 0.388 & 0.299 \\
\hline Observations & 538 & 538 & 538 & 538 \\
\hline F-stat & 251.3 & 251.3 & 251.3 & 251.3 \\
\hline Group & All natives & All native whites & Native parentage & $\begin{array}{l}\text { Mixed/foreign } \\
\text { parentage }\end{array}$ \\
\hline
\end{tabular}

Table E6. Immigration and Internal Migration

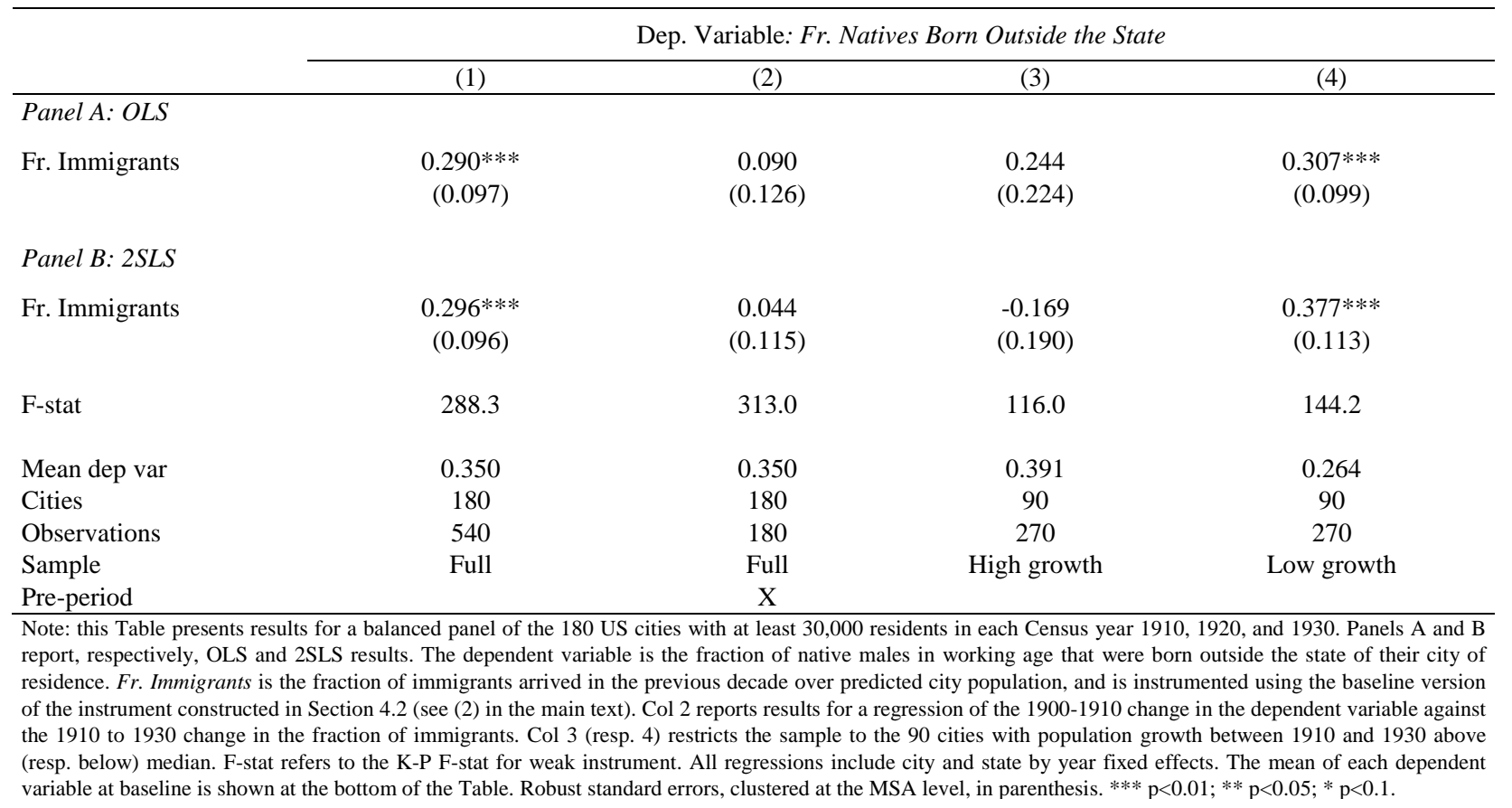




\section{Table E7. Share of Electric Power in Manufacture (1930)}

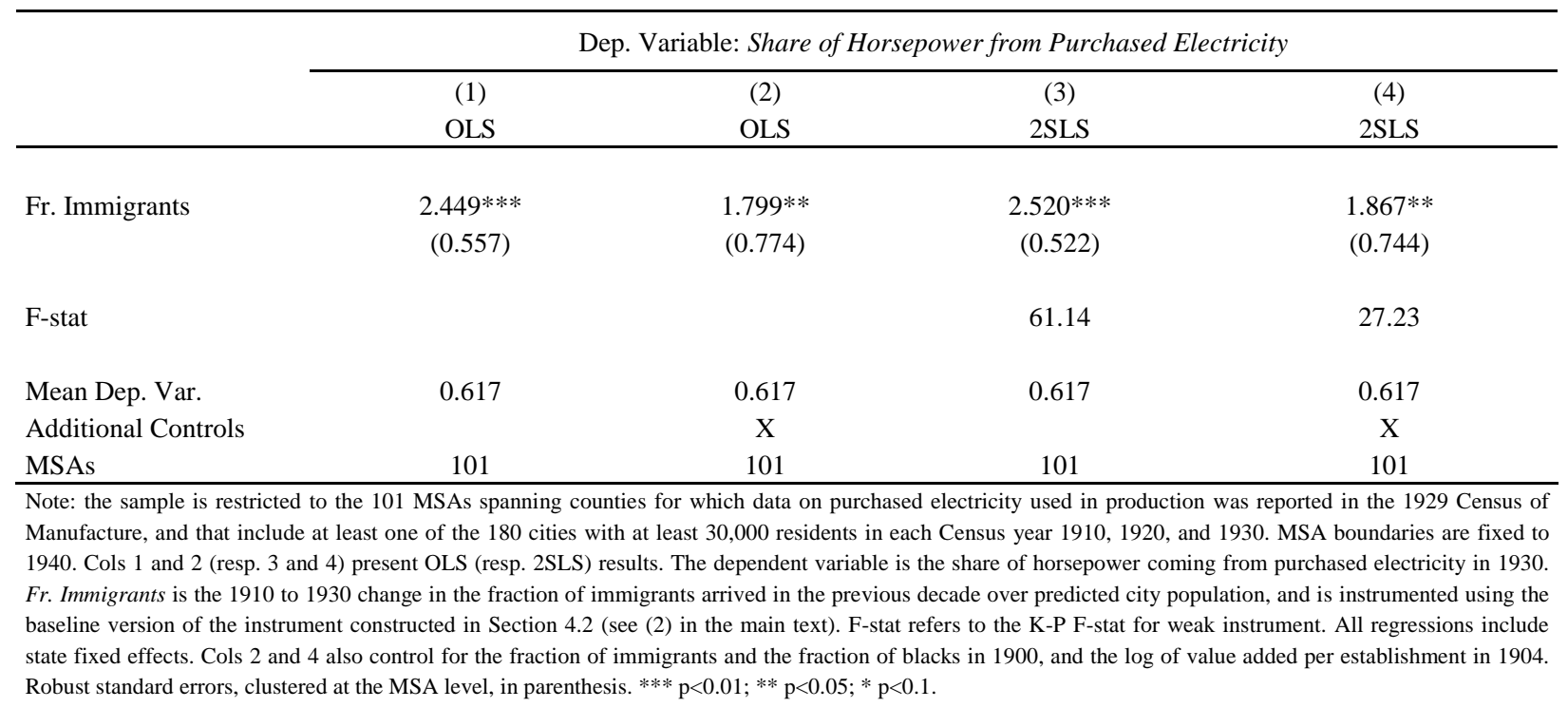

\section{Table E8. Heterogeneity: City Size and Population Density}

\begin{tabular}{|c|c|c|c|c|c|c|c|c|}
\hline & $\begin{array}{c}(1) \\
\text { Public } \\
\text { Spending PC }\end{array}$ & $\begin{array}{c}(2) \\
\text { Prop. Tax } \\
\text { Rate }\end{array}$ & $\begin{array}{c}\text { (3) } \\
\text { Democrats' } \\
\text { Vote Share }\end{array}$ & $\begin{array}{c}(4) \\
\text { DW Nominate } \\
\text { Scores }\end{array}$ & $\begin{array}{c}\text { (5) } \\
\text { Employed }\end{array}$ & $\begin{array}{c}(6) \\
\text { Log Occ. } \\
\text { Scores }\end{array}$ & $\begin{array}{c}\text { (7) } \\
\text { Log Value Added } \\
\text { per Establ. }\end{array}$ & $\begin{array}{c}(8) \\
\text { Log Establ. } \\
\text { Size }\end{array}$ \\
\hline \multicolumn{9}{|c|}{ Panel A. City population } \\
\hline Fr. Immigrants & $\begin{array}{c}-18.08 * * * \\
(3.523)\end{array}$ & $\begin{array}{l}-35.37 \\
(25.78)\end{array}$ & $\begin{array}{c}-0.346 * * \\
(0.139)\end{array}$ & $\begin{array}{c}1.023 \\
(0.749)\end{array}$ & $\begin{array}{c}0.261 * * * \\
(0.042)\end{array}$ & $\begin{array}{c}0.062 \\
(0.040)\end{array}$ & $\begin{array}{c}2.137 * * * \\
(0.605)\end{array}$ & $\begin{array}{c}2.087 * * * \\
(0.516)\end{array}$ \\
\hline Interaction & $\begin{array}{c}3.126 * * * \\
(0.992)\end{array}$ & $\begin{array}{c}11.43^{* * * *} \\
(3.211)\end{array}$ & $\begin{array}{c}-0.047 * * * \\
(0.018)\end{array}$ & $\begin{array}{c}0.476 * * * \\
(0.092)\end{array}$ & $\begin{array}{c}-0.028^{* * *} * \\
(0.005)\end{array}$ & $\begin{array}{c}0.007 \\
(0.007)\end{array}$ & $\begin{array}{c}0.225^{* * * *} \\
(0.054)\end{array}$ & $\begin{array}{c}0.357 * * * \\
(0.081)\end{array}$ \\
\hline KP F-stat & 131.8 & 132.9 & 34.28 & 9.454 & 118.4 & 118.4 & 131.8 & 131.8 \\
\hline AP F-stat (Imm.) & 133.1 & 134.2 & 70.25 & 16.93 & 119.7 & 119.7 & 133.2 & 133.2 \\
\hline AP F-stat(Int.) & 2,289 & 2,282 & 1,193 & 4,454 & 2,240 & 2,240 & 2,483 & 2,483 \\
\hline Observations & 540 & 539 & 378 & 470 & 538 & 538 & 525 & 525 \\
\hline \multicolumn{9}{|l|}{ Panel B. Density } \\
\hline Fr. Immigrants & $\begin{array}{c}-12.36 * * * \\
(4.303)\end{array}$ & $\begin{array}{c}-28.70 \\
(31.052)\end{array}$ & $\begin{array}{c}-0.370 * * * \\
(0.138)\end{array}$ & $\begin{array}{c}1.698 * * \\
(0.751)\end{array}$ & $\begin{array}{c}0.270 * * * \\
(0.040)\end{array}$ & $\begin{array}{c}0.013 \\
(0.042)\end{array}$ & $\begin{array}{c}2.175^{* * *} * \\
(0.654)\end{array}$ & $\begin{array}{c}1.974 * * * \\
(0.573)\end{array}$ \\
\hline Interaction & $\begin{array}{c}-5.493 * * * \\
(1.292)\end{array}$ & $\begin{array}{l}-5.232 \\
(8.435)\end{array}$ & $\begin{array}{l}-0.050 \\
(0.069)\end{array}$ & $\begin{array}{l}-0.022 \\
(0.471)\end{array}$ & $\begin{array}{l}-0.023 \\
(0.016)\end{array}$ & $\begin{array}{c}0.064 * * * \\
(0.021)\end{array}$ & $\begin{array}{l}-0.001 \\
(0.399)\end{array}$ & $\begin{array}{c}0.193 \\
(0.355)\end{array}$ \\
\hline KP F-stat & 114.5 & 115.5 & 36.36 & 13.94 & 101.0 & 101.0 & 113.4 & 113.4 \\
\hline AP F-stat (Imm.) & 130.3 & 130.7 & 44.95 & 19.76 & 116.6 & 116.6 & 129.4 & 129.4 \\
\hline AP F-stat(Int.) & 9,267 & 9,187 & 121.2 & 39.37 & 9,536 & 9,536 & 9,282 & 9,282 \\
\hline Observations & 531 & 530 & 372 & 451 & 529 & 529 & 519 & 519 \\
\hline
\end{tabular}




\section{Table E9. Heterogeneity: Average Length of Stay}

\begin{tabular}{|c|c|c|c|c|c|c|c|c|}
\hline & $\begin{array}{c}\text { (1) } \\
\text { Public } \\
\text { Spending PC }\end{array}$ & $\begin{array}{c}(2) \\
\text { Prop. Tax } \\
\text { Rate }\end{array}$ & $\begin{array}{c}(3) \\
\text { Democrats' } \\
\text { Vote Share }\end{array}$ & $\begin{array}{c}\text { (4) } \\
\text { DW Nominate } \\
\text { Scores }\end{array}$ & $\begin{array}{c}(5) \\
\text { Employed }\end{array}$ & $\begin{array}{c}(6) \\
\text { Log Occ. } \\
\text { Scores }\end{array}$ & $\begin{array}{c}(7) \\
\text { Log Value Added } \\
\text { per Establ. }\end{array}$ & $\begin{array}{c}(8) \\
\text { Log Establ. } \\
\text { Size }\end{array}$ \\
\hline Fr. Immigrants & $\begin{array}{l}-8.890 * \\
(4.771)\end{array}$ & $\begin{array}{c}-31.713^{*} \\
(17.95)\end{array}$ & $\begin{array}{c}-0.337 * * \\
(0.146)\end{array}$ & $\begin{array}{l}1.729 * * \\
(0.864)\end{array}$ & $\begin{array}{c}0.294 * * * \\
(0.068)\end{array}$ & $\begin{array}{l}0.102 * * \\
(0.041)\end{array}$ & $\begin{array}{c}3.059 * * * \\
(1.010)\end{array}$ & $\begin{array}{c}2.675 * * * \\
(0.865)\end{array}$ \\
\hline $\begin{array}{l}\text { Fr. Imm.*1[high } \\
\text { length of stay] }\end{array}$ & $\begin{array}{l}-2.825 \\
(17.57)\end{array}$ & $\begin{array}{l}-35.71 \\
(46.06)\end{array}$ & $\begin{array}{c}0.784 * * \\
(0.374)\end{array}$ & $\begin{array}{c}0.861 \\
(1.571)\end{array}$ & $\begin{array}{l}-0.078 \\
(0.157)\end{array}$ & $\begin{array}{c}0.070 \\
(0.175)\end{array}$ & $\begin{array}{c}2.499 \\
(1.793)\end{array}$ & $\begin{array}{c}2.097 \\
(1.537)\end{array}$ \\
\hline KP F-stat & 40.55 & 43.09 & 29.68 & 15.42 & 38.67 & 38.67 & 37.32 & 37.32 \\
\hline AP F-stat (Imm.) & 201.7 & 203.2 & 41.43 & 13.90 & 179.7 & 179.7 & 196.7 & 196.7 \\
\hline AP F-stat(Int.) & 138.7 & 145.5 & 46.53 & 52.34 & 138.4 & 138.4 & 132.6 & 132.6 \\
\hline Observations & 540 & 539 & 378 & 460 & 538 & 538 & 525 & 525 \\
\hline
\end{tabular}

Note: this table tests the heterogeneity of results for the 8 outcomes reported at the top of each column by interacting the fraction of immigrants with a dummy equal to 1 if the average length of stay of immigrants living in the city in 1910 was above the median (18 years). The interaction term is instrumented with the interaction between the instrument for immigration and the relevant interaction variable. KP F-stat is the Kleibergen-Paap F stat for joint significance of instruments. AP F-stat (Imm.) and AP F-stat (Int.) refer to the partial F-stats for joint significance of the instruments in the two separate first-stage regressions. All regressions include city and state by year fixed effects. Robust standard errors, clustered at the MSA level, in parenthesis. ${ }^{* * *} \mathrm{p}<0.01 ;{ }^{*} * \mathrm{p}<0.05 ; * \mathrm{p}<0.1$.

Table E10. A Horse-Race Between Religion and Linguistic Distance (2SLS)

\begin{tabular}{|c|c|c|c|c|c|c|c|c|}
\hline Dep. Var. & $\begin{array}{c}1) \\
\text { Total tax } \\
\text { revenues PC }\end{array}$ & $\begin{array}{c}(2) \\
\text { Property tax } \\
\text { revenues PC }\end{array}$ & $\begin{array}{l}(3) \\
\text { Property tax } \\
\text { rate }\end{array}$ & $\begin{array}{c}(4) \\
\text { Public } \\
\text { spending PC }\end{array}$ & $\begin{array}{c}(5) \\
\text { Dem-Rep. } \\
\text { margin }\end{array}$ & $\begin{array}{c}\text { (6) } \\
\text { Smith's pct. } \\
\text { votes }\end{array}$ & $\begin{array}{c}(7) \\
\text { DW Nominate } \\
\text { Scores }\end{array}$ & $\begin{array}{c}(8) \\
1[\text { Restrict } \\
\text { Immigration] }\end{array}$ \\
\hline Ling. Distance & $\begin{array}{l}-0.860^{*} \\
(0.474)\end{array}$ & $\begin{array}{l}-0.802 * \\
(0.463)\end{array}$ & $\begin{array}{l}-2.309 \\
(1.593)\end{array}$ & $\begin{array}{l}-0.516^{*} \\
(0.303)\end{array}$ & $\begin{array}{c}0.036^{* * *} \\
(0.015)\end{array}$ & $\begin{array}{l}0.065^{*} \\
(0.033)\end{array}$ & $\begin{array}{c}0.028 \\
(0.030)\end{array}$ & $\begin{array}{l}-0.033 \\
(0.061)\end{array}$ \\
\hline Fr. Non-Prot & $\begin{array}{l}-0.108 \\
(0.417)\end{array}$ & $\begin{array}{l}-0.104 \\
(0.382)\end{array}$ & $\begin{array}{l}-0.122 \\
(0.879)\end{array}$ & $\begin{array}{l}-0.122 \\
(0.257)\end{array}$ & $\begin{array}{c}-0.041 * * * \\
(0.013)\end{array}$ & $\begin{array}{c}-0.148 * * * \\
(0.031)\end{array}$ & $\begin{array}{c}0.049 \\
(0.037)\end{array}$ & $\begin{array}{c}0.157 * * * \\
(0.060)\end{array}$ \\
\hline Fr. Prot & $\begin{array}{c}0.213 \\
(0.411)\end{array}$ & $\begin{array}{c}0.086 \\
(0.375)\end{array}$ & $\begin{array}{l}-0.051 \\
(1.029)\end{array}$ & $\begin{array}{c}0.005 \\
(0.267)\end{array}$ & $\begin{array}{l}-0.009 \\
(0.013)\end{array}$ & $\begin{array}{c}0.072 \\
(0.044)\end{array}$ & $\begin{array}{c}0.006 \\
(0.030)\end{array}$ & $\begin{array}{l}-0.071 \\
(0.081)\end{array}$ \\
\hline KP F-stat & 14.72 & 14.72 & 15.01 & 14.72 & 8.111 & 5.841 & 13.57 & 9.314 \\
\hline F-stat (Ling.) & 37.91 & 37.91 & 40.05 & 37.91 & 30.54 & 30.33 & 25.25 & 19.45 \\
\hline F-stat (Non-Prot) & 65.52 & 65.52 & 66.81 & 65.52 & 39.39 & 29.81 & 57.43 & 46.80 \\
\hline F-stat (Prot) & 20.91 & 20.91 & 20.66 & 20.91 & 27.37 & 23.31 & 23.01 & 16.79 \\
\hline Mean of dep var. & 12.76 & 12.10 & 19.75 & 12.16 & 0.180 & 0.398 & 0.165 & 0.676 \\
\hline Observations & 540 & 540 & 539 & 540 & 378 & 126 & 460 & 155 \\
\hline \multicolumn{9}{|c|}{$\begin{array}{l}\text { Note: this table replicates results reported in Table } 7 \text { in the main text, including simultaneously immigration from different religious groups and the index of } \\
\text { linguistic distance introduced in Section } 7.2 \text { in the paper. The dependent variable is displayed at the top of each column. To ease the interpretation of results, the } \\
\text { fraction of immigrants from Protestant (Fr. Prot) and from non-Protestant (Fr. Non-Prot) countries are both standardized by subtracting their mean and dividing } \\
\text { them by their standard deviation. All regressors are instrumented using the instruments constructed in the main text. KP F-stat is the Kleibergen-Paap F stat for joint } \\
\text { significance of instruments. F-stat (Ling.). F-stat (Non-Prot), and F-stat(Prot) refer to the partial F-stats for joint significance of the instruments in the three separate } \\
\text { first-stage regressions. Cols } 1 \text { to } 4 \text { (resp. 5) include city (resp. MSA) and state by year fixed effects, while Col } 7 \text { includes congressional district by city and state by } \\
\text { year fixed effects. Cols } 6 \text { and } 8 \text { present results from a cross-sectional regression and control for state dummies. Robust standard errors, clustered at the MSA level, in } \\
\text { parenthesis. *** p }<0.01 ; * * \text { p }<0.05 ; * \text { p }<0.1 \text {. }\end{array}$} \\
\hline
\end{tabular}




\section{Table E11. Immigration and Ethnic Diversity}

\begin{tabular}{|c|c|c|c|c|c|c|c|c|}
\hline Dep. Var. & $\begin{array}{c}(1) \\
\text { Total tax } \\
\text { revenues PC }\end{array}$ & $\begin{array}{c}(2) \\
\text { Property tax } \\
\text { revenues PC }\end{array}$ & $\begin{array}{c}(3) \\
\text { Property tax } \\
\text { rate }\end{array}$ & $\begin{array}{c}(4) \\
\text { Public } \\
\text { spending PC }\end{array}$ & $\begin{array}{c}(5) \\
\text { Education }\end{array}$ & $\begin{array}{c}(6) \\
\text { Police }\end{array}$ & $\begin{array}{c}(7) \\
\text { Charities and } \\
\text { Hospitals } \\
\end{array}$ & $\begin{array}{c}(8) \\
\text { Sanitation }\end{array}$ \\
\hline \multicolumn{9}{|l|}{ Panel A: OLS } \\
\hline $\begin{array}{l}\text { Fr. Immigrants } \\
(\text { Fr.Imm.)*ED }\end{array}$ & $\begin{array}{c}-7.092 \\
(6.030) \\
-9.749 * * \\
(4.647)\end{array}$ & $\begin{array}{c}-6.817 \\
(5.055) \\
-9.390^{*} \\
(4.749)\end{array}$ & $\begin{array}{c}-28.35 * * * \\
(10.82) \\
0.626 \\
(7.772)\end{array}$ & $\begin{array}{c}-4.803 \\
(3.705) \\
-6.107 * * \\
(2.969)\end{array}$ & $\begin{array}{c}-7.178 * * * \\
(2.248) \\
-2.882 * * \\
(1.253)\end{array}$ & $\begin{array}{c}0.263 \\
(0.586) \\
-0.760 * \\
(0.423)\end{array}$ & $\begin{array}{c}0.828 \\
(0.701) \\
-0.480 \\
(0.740)\end{array}$ & $\begin{array}{c}-0.433 \\
(0.667) \\
-1.614 * * \\
(0.672)\end{array}$ \\
\hline \multicolumn{9}{|l|}{ Panel B: $2 S L S$} \\
\hline $\begin{array}{l}\text { Fr. Immigrants } \\
(\text { Fr. Imm.)*ED }\end{array}$ & $\begin{array}{c}-9.885 \\
(6.477) \\
-15.43 * * * \\
(4.587)\end{array}$ & $\begin{array}{c}-10.133 * \\
(5.934) \\
-15.28 * * * \\
(4.458)\end{array}$ & $\begin{array}{c}-30.31 * \\
(17.709) \\
-13.71 \\
(11.26)\end{array}$ & $\begin{array}{c}-7.564 * \\
(4.125) \\
-10.69 * * * \\
(3.665)\end{array}$ & $\begin{array}{c}-5.933 * * * \\
(2.097) \\
-1.903 \\
(1.414)\end{array}$ & $\begin{array}{c}-0.305 \\
(0.680) \\
-0.223 \\
(0.648)\end{array}$ & $\begin{array}{l}-0.759 \\
(1.703) \\
-0.800 \\
(0.802)\end{array}$ & $\begin{array}{c}-1.211^{*} \\
(0.716) \\
-0.897 \\
(0.562)\end{array}$ \\
\hline $\begin{array}{l}\text { KP F-stat } \\
\text { F-stat (Imm.) } \\
\text { F-stat (Imm_ED) }\end{array}$ & $\begin{array}{l}21.39 \\
146.4 \\
18.31\end{array}$ & $\begin{array}{l}21.39 \\
146.4 \\
18.31\end{array}$ & $\begin{array}{l}21.37 \\
148.4 \\
18.30\end{array}$ & $\begin{array}{l}21.39 \\
146.4 \\
18.31\end{array}$ & $\begin{array}{l}20.80 \\
130.3 \\
30.06\end{array}$ & $\begin{array}{l}21.39 \\
146.4 \\
18.31\end{array}$ & $\begin{array}{l}15.80 \\
114.4 \\
16.00\end{array}$ & $\begin{array}{l}21.39 \\
146.4 \\
18.31\end{array}$ \\
\hline $\begin{array}{l}\text { Mean of dep var } \\
\text { Observations }\end{array}$ & $\begin{array}{c}12.76 \\
540\end{array}$ & $\begin{array}{c}12.10 \\
540\end{array}$ & $\begin{array}{c}19.75 \\
539\end{array}$ & $\begin{array}{c}12.16 \\
540 \\
\end{array}$ & $\begin{array}{c}4.250 \\
534 \\
\end{array}$ & $\begin{array}{c}1.338 \\
540 \\
\end{array}$ & $\begin{array}{c}0.635 \\
516 \\
\end{array}$ & $\begin{array}{c}1.129 \\
540 \\
\end{array}$ \\
\hline $\begin{array}{l}\text { Note: this Table pres } \\
\text { report, respectively, } \\
\text { capita on the categor } \\
\text { population, and is ins } \\
\text { between the fraction } \\
\text { instrumented with the } \\
\text { joint significance of } \\
\text { regressions include th } \\
\text { level, in parenthesis. }\end{array}$ & $\begin{array}{l}\text { sults for a bala } \\
\text { d } 2 \text { SLS result } \\
d \text { at the top c } \\
\text { ted using the } \\
\text { migrants and } \\
\text { ction between } \\
\text { truments in th } \\
\text { effect of the } \\
0.01 ; * * \text { p }<0.0\end{array}$ & $\begin{array}{l}\text { nced panel of th } \\
\text { s. The depende } \\
\text { f the column. } \\
\text { baseline versiol } \\
\text { the (standardiz } \\
\text { predicted immi } \\
\text { e two separate } \\
\text { index of ethnic } \\
5: * \text { p }<0.1 \text {. }\end{array}$ & $\begin{array}{l}0 \text { US cities v } \\
\text { riable is disp } \\
\text { mmigrants } \mathrm{r} \\
\text { the instrumer } \\
\text { ndex of ethr } \\
\text { on and the in } \\
\text { stage regress } \\
\text { sity, and con }\end{array}$ & $\begin{array}{l}\text { theast } 30,00 \\
\text { at the top o } \\
\text { to the fracti } \\
\text { astructed in S } \\
\text { iversity of th } \\
\text { f ethnic dive } \\
\text { KP F-stat is }\end{array}$ & $\begin{array}{l}\text { idents in ea } \\
\text { ch column. } \\
\text { f immigrar } \\
\text { on } 4.2 \text { (see } \\
\text { reign born } \\
\text { F-stat (Im } \\
\text { Kleiberger }\end{array}$ & $\begin{array}{l}\text { nsus year } \\
\text { ls } 5 \text { to } 8 \text {, } \\
\text { ived in tl } \\
\text { the main } \\
\text { lation co } \\
\text { d F-stat } \\
\text { F stat fo }\end{array}$ & $\begin{array}{l}\text { 1920, and } 19 . \\
\text { lependent varia } \\
\text { evious decade } \\
\text { (Fr. Imm.)*E } \\
\text { cted in online } \\
\text { ED) refer to th } \\
\text { th significance }\end{array}$ & $\begin{array}{l}\text { anels A and B } \\
\text { s spending pe } \\
\text { predicted city } \\
\text { the interaction } \\
\text { ndix E9. It is } \\
\text { rtial F-stats fo } \\
\text { struments. Al }\end{array}$ \\
\hline
\end{tabular}




\section{Figure E1. Percent Change in Fraction of Natives in Selected Occupations}

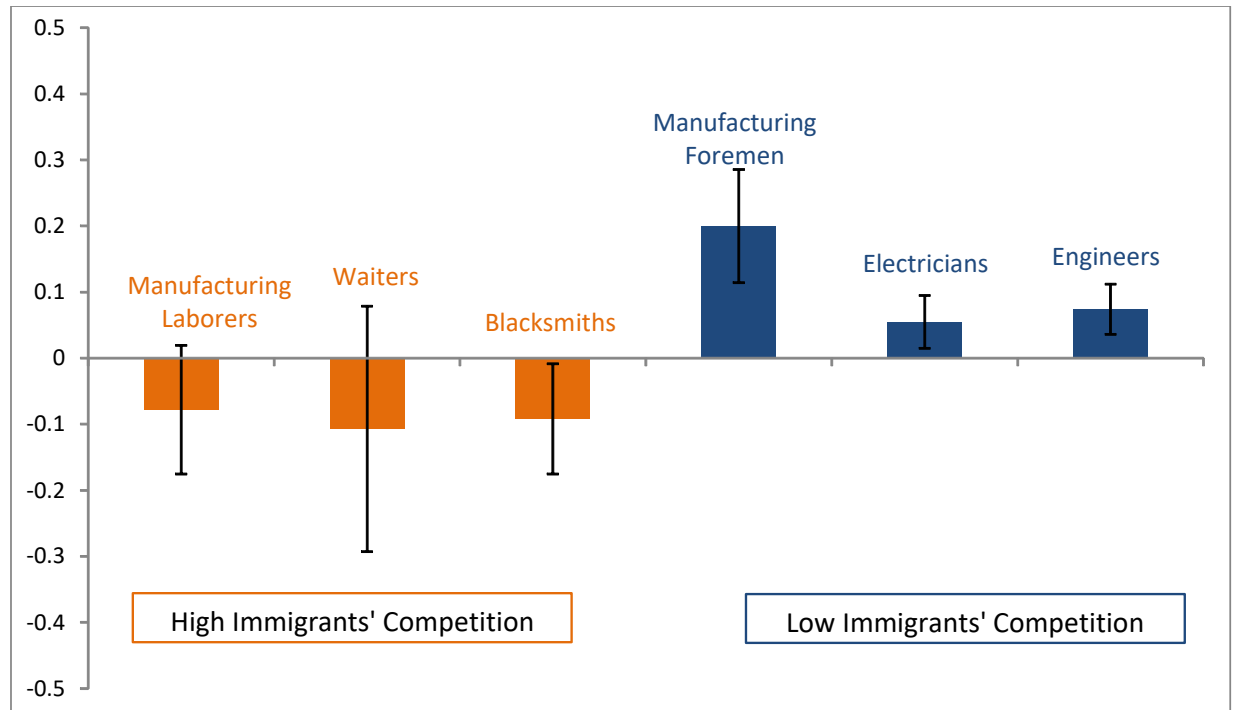

Note: the figure plots the percent change in the fraction of natives in each occupation (relative to its 1910 mean) implied by a one standard deviation increase in immigration, according to 2SLS estimates (with corresponding 95\% confidence intervals) reported in Table E1.

Figure E2. Linguistic Distance and Natives' Labor Market Outcomes

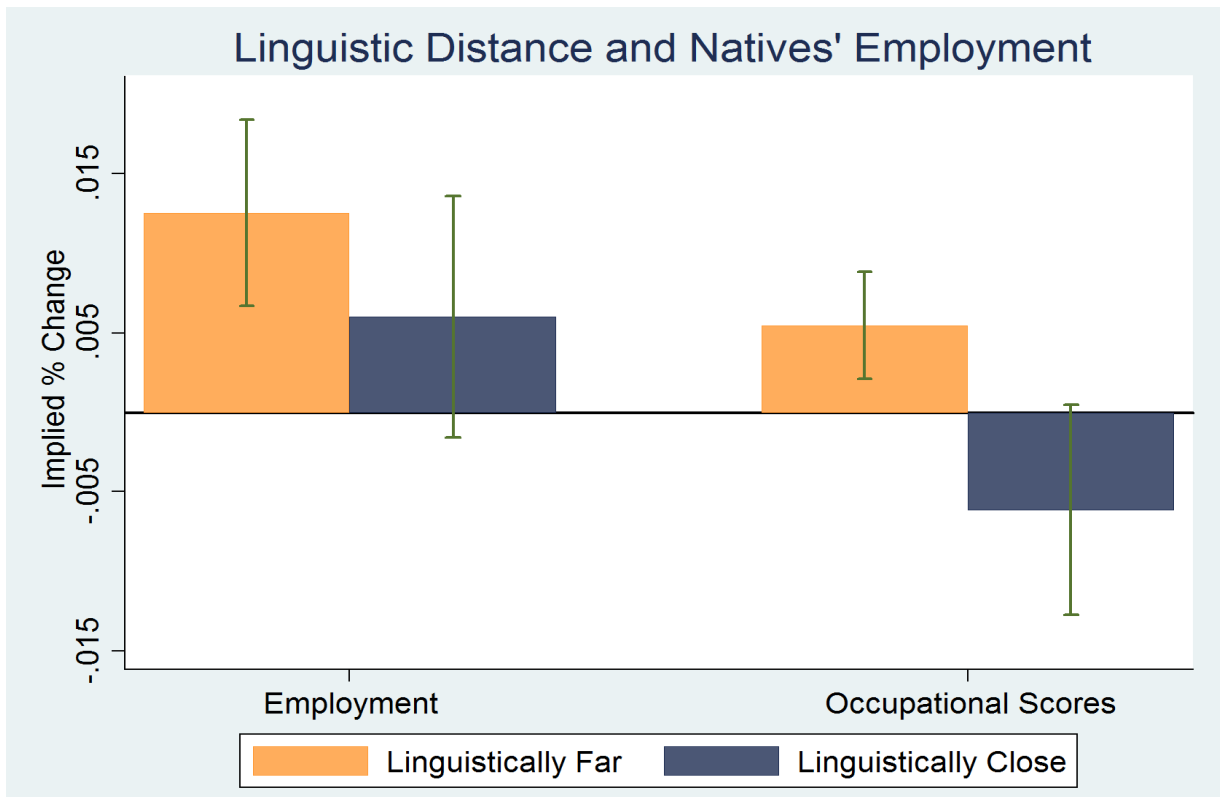

Note: this figure plots the 2SLS estimates for the percent change in employment and occupational scores for native men of working age implied by one standard deviation change (0.05) in the fraction of immigrants with associated $95 \%$ confidence intervals, for immigrants coming from linguistically far and linguistically close countries. Countries are classified as linguistically far (resp. close) if they are above (resp. below) the median linguistic distance from English as computed by Chiswick and Miller (2005). See also Table E3. 


\section{Figure E3. Percent Change in Fraction of Immigrants in Selected Occupations}

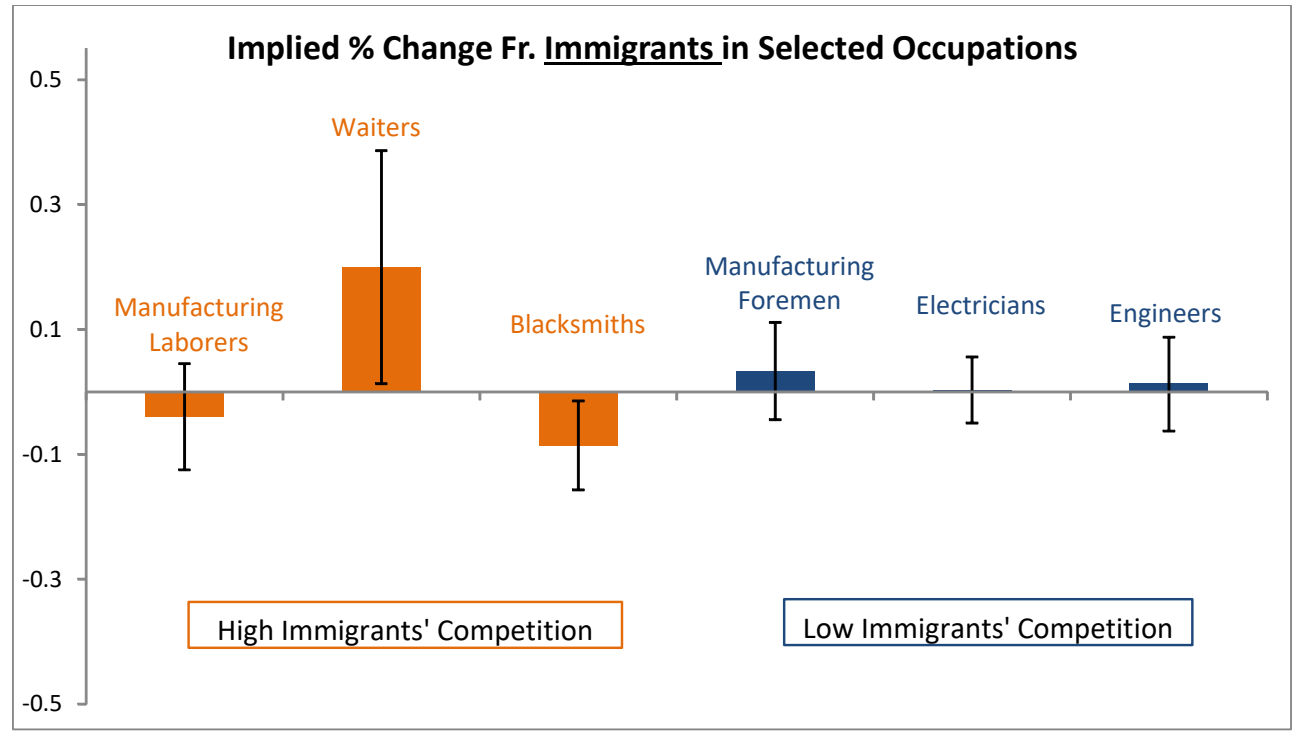

Note: the figure replicates Figure E1 by plotting the percent change in the fraction of immigrants arrived at least 10 year before in each occupation (relative to its 1910 mean) implied by a one standard deviation increase in immigration, according to 2 SLS estimates (with corresponding $95 \%$ confidence intervals).

\section{Figure E4. Effects of Immigration on Previously Arrived Immigrants}

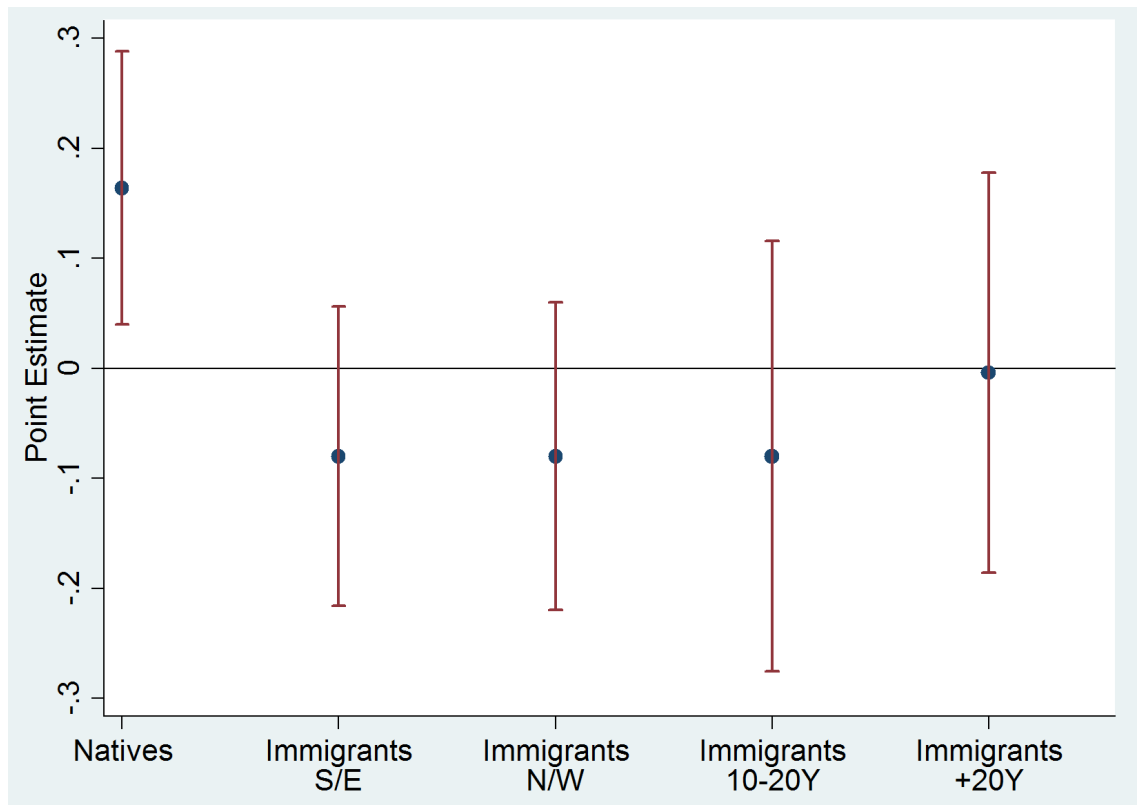

Note: the figure plots the coefficient (with corresponding $95 \%$ confidence intervals) from a regression of immigration on employment of different groups of men in age (15-65) who were not in school. The fraction of immigrants is instrumented with the instrument constructed in equation (2) of Section 4.2 in the main text. All regressions control for city and state by year fixed effects, and include interactions between the 1900 fraction of immigrants and year dummies. Immigrants S/E (resp. $N / W$ ) refers to immigrants from Eastern and Southern (resp. Northern and Western) Europe. Immigrants 10-20Y (resp. $+20 Y$ ) refers to immigrants that spent between 10 and 20 (resp. more than 20) years in the United States. 
Figure E5. 1910-1930 Immigration and 1930 Natives' Rents

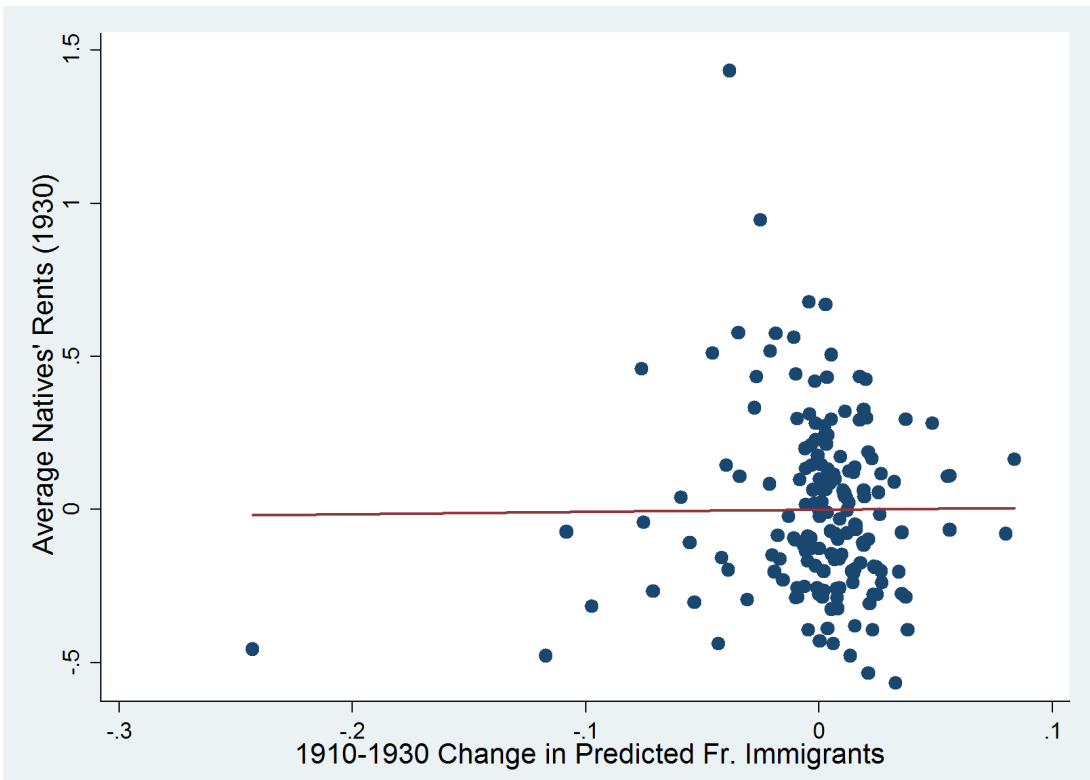

Note: this figure plots the relationship between the log of 1930 average rents paid by natives (y-axis) and the 1910 to 1930 predicted change in immigration ( $\mathrm{x}$-axis) after partialling out state fixed effects.

Figure E6. Religion and Natives' Employment



Note: the figure plots the 2SLS coefficient (with corresponding 95\% confidence intervals) for the effects of non-Protestant (orange bars) and Protestant (blue bars) immigrants on natives' employment. The dependent variable is the employment to population ratio for native men of age 15-65. The regressors of interest are the fraction of non-Protestant and Protestant immigrants, which are standardized by subtracting their mean and dividing through their standard deviation. The bars on the left (resp. on the right) plot results obtained for the full sample (resp. dropping the city of Passaic, NJ). All regressions control for city and state by year fixed effects. 


\section{Figure E7. Religion and Economic Activity}

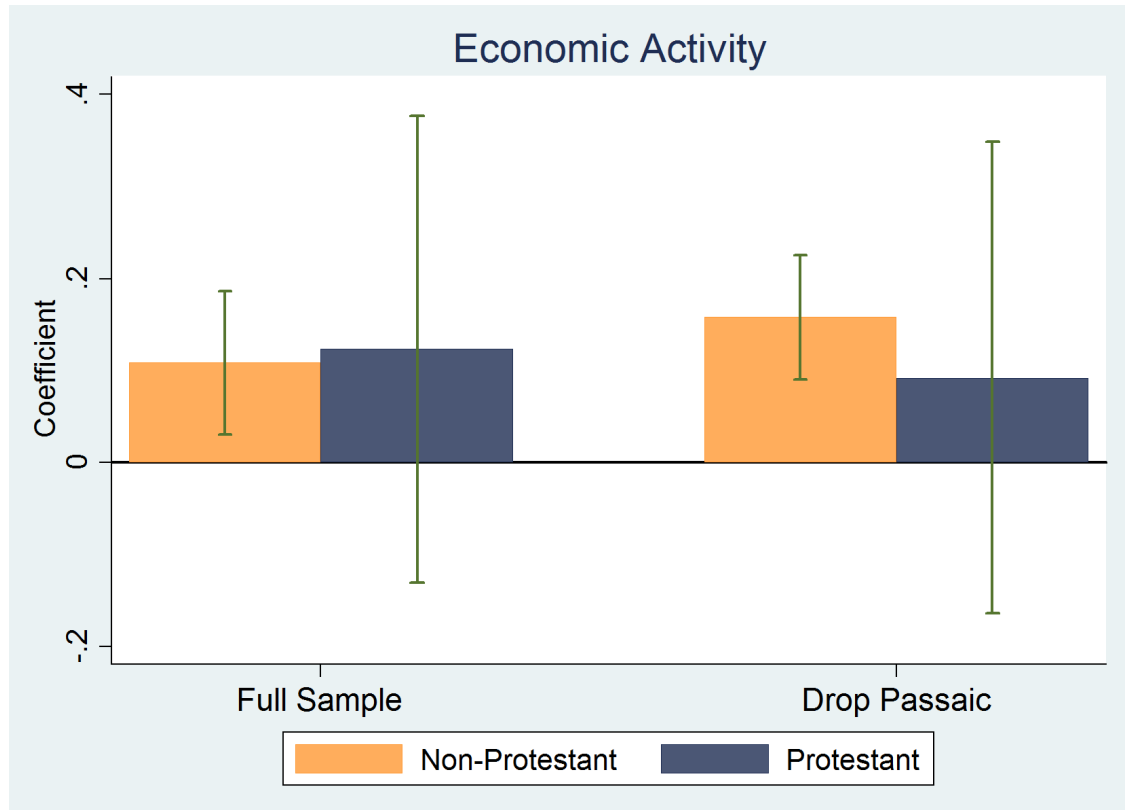

Note: the figure plots the 2SLS coefficient (with corresponding 95\% confidence intervals) for the effects of non-Protestant (orange bars) and Protestant (blue bars) immigrants on the log of value added by manufacturing per establishment. The regressors of interest are the fraction of non-Protestant and Protestant immigrants, which are standardized by subtracting their mean and dividing through their standard deviation. The bars on the left (resp. on the right) plot results obtained for the full sample (resp. dropping the city of Passaic, NJ). All regressions control for city and state by year fixed effects.

\section{References}

Abramitzky, R., P. Ager, L. Boustan, E. Cohen, and C. W. Hansen (2019). The effect of immigration on the economy: Lessons from closing and re-opening the us border over the 20th century. Unpublished.

Abramitzky, R. and L. P. Boustan (2017). Immigration in american economic history. Journal of Economic Literature 55(4).

Abramitzky, R., L. P. Boustan, and K. Eriksson (2018). Cultural assimilation during the two ages of mass migration. Working paper.

Alesina, A., R. Baqir, and W. Easterly (1999). Public goods and ethnic divisions. The Quarterly Journal of Economics 114(4), 1243-1284.

Bandiera, O., M. Mohnen, I. Rasul, and M. Viarengo (2019). Nation-building through compulsory schooling during the age of mass migration. Economic Journal, Forthcoming.

Beach, B. and D. B. Jones (2017). Gridlock: Ethnic diversity in government and the provision of public goods. American Economic Journal: Economic Policy 9(1), 112-36. 
Biavaschi, C., C. Giulietti, and Z. Siddique (2017). The economic payoff of name americanization. Journal of Labor Economics 35(4), 1089-1116.

Borjas, G. J. (2003). The labor demand curve is downward sloping: Reexamining the impact of immigration on the labor market. The quarterly journal of economics 118(4), 13351374.

Borjas, G. J. (2016). We Wanted Workers: Unraveling the Immigration Narrative. WW Norton \& Company.

Borusyak, K., P. Hull, and X. Jaravel (2018). Quasi-experimental shift-share research designs. Working Paper.

Boustan, L. P. (2010). Was postwar suburbanization" white flight"? evidence from the black migration. The Quarterly Journal of Economics 125, 417-443.

Burchardi, K. B., T. Chaney, and T. A. Hassan (2019). Migrants, ancestors, and investments. Review of Economic Studies, Forthcoming.

Card, D. (2001). Immigrant inflows, native outflows, and the local labor market impacts of higher immigration. Journal of Labor Economics 19(1), 22-64.

Card, D., C. Dustmann, and I. Preston (2012). Immigration, wages, and compositional amenities. Journal of the European Economic Association 10(1), 78-119.

Carlana, M. and M. Tabellini (2018). Happily ever after: Immigration, natives' marriage, and fertility. Working Paper.

Cascio, E. U. and A. Narayan (2015). Who needs a fracking education? the educational response to low-skill biased technological change. Technical report, National Bureau of Economic Research.

Charles, K. K., E. Hurst, and M. J. Notowidigdo (2018). Housing booms and busts, labor market opportunities, and college attendance. American Economic Review 108(10), 294794.

Chiswick, B. R. and P. W. Miller (2005). Linguistic distance: A quantitative measure of the distance between english and other languages. Journal of Multilingual and Multicultural Development 26(1), 1-11. 
Feng, S., A. B. Krueger, and M. Oppenheimer (2010). Linkages among climate change, crop yields and mexico-us cross-border migration. Proceedings of the National Academy of Sciences 107(32), 14257-14262.

Foged, M. and G. Peri (2016). Immigrants' effect on native workers: New analysis on longitudinal data. American Economic Journal: Applied Economics 8(2), 1-34.

Fouka, V. (2018). Backlash: The unintended effects of language prohibition in us schools after world war i.

Goldin, C. (1994). The political economy of immigration restriction in the united states, 1890 to 1921. In The regulated economy: A historical approach to political economy, pp. 223-258. University of Chicago Press.

Goldin, C. D. and L. F. Katz (2009). The race between education and technology. Harvard University Press.

Goldsmith-Pinkham, P., I. Sorkin, and H. Swift (2018). Bartik instruments: What, when, why, and how. Working paper, National Bureau of Economic Research.

Greenwood, M. J. and Z. Ward (2015). Immigration quotas, world war i, and emigrant flows from the united states in the early 20th century. Explorations in Economic History 55, $76-96$.

Hatton, T. J. and J. G. Williamson (1998). The age of mass migration: Causes and economic impact. Oxford University Press on Demand.

Higham, J. (1955). Strangers in the land: Patterns of American nativism, 1860-1925. Rutgers University Press.

Jaeger, D. A., J. Ruist, and J. Stuhler (2018). Shift-share instruments and the impact of immigration. Working paper, National Bureau of Economic Research.

Katz, L. F. and R. A. Margo (2014). Technical change and the relative demand for skilled labor: The united states in historical perspective. In Human capital in history: The American record, pp. 15-57. University of Chicago Press.

Kleppner, P. (1982). Who voted?: The dynamics of electoral turnout, 1870-1980. Praeger Publishers. 
Lafortune, J. and J. Tessada (2014). Smooth (er) landing? the role of networks in the location and occupational choice of immigrants. Technical report, Mimeo, Instituto de Economía, Pontificia Universidad Católica de Chile September 2013.

Li, G. (1985). Robust regression. Exploring data tables, trends, and shapes 281, U340.

Luterbacher, J., D. Dietrich, E. Xoplaki, M. Grosjean, and H. Wanner (2004). European seasonal and annual temperature variability, trends, and extremes since 1500. Science 303(5663), 1499-1503.

Luttmer, E. F. (2001). Group loyalty and the taste for redistribution. Journal of political Economy 109(3), 500-528.

Meyer, S. (1981). The five dollar day: Labor management and social control in the Ford Motor Company, 1908-1921. State University of New York Press.

Oster, E. (2017). Unobservable selection and coefficient stability: Theory and evidence. Journal of Business 83 Economic Statistics, 1-18.

Ottaviano, G. I. and G. Peri (2012). Rethinking the effect of immigration on wages. Journal of the European economic association 10(1), 152-197.

Pauling, A., J. Luterbacher, C. Casty, and H. Wanner (2006). Five hundred years of gridded high-resolution precipitation reconstructions over europe and the connection to large-scale circulation. Climate Dynamics 26(4), 387-405.

Peri, G. and C. Sparber (2009). Task specialization, immigration, and wages. American Economic Journal: Applied Economics 1(3), 135-69.

Saiz, A. and S. Wachter (2011). Immigration and the neighborhood. American Economic Journal: Economic Policy 3(2), 169-188.

Sequeira, S., N. Nunn, and N. Qian (2019). Immigrants and the making of america. Review of Economic Studies, Forthcoming.

Shertzer, A. (2016). Immigrant group size and political mobilization: Evidence from european migration to the united states. Journal of Public Economics 139, 1-12.

Solomou, S. and W. Wu (1999). Weather effects on european agricultural output, 1850-1913. European Review of Economic History 3(3), 351-373.

Stuart, B. A. and E. J. Taylor (2016). Social interactions and location decisions: Evidence from us mass migration. Unpublished working paper. 